UNIVERSIDADE DE BRASILIA

INSTITUTO DE CIÊNCIAS SOCIAIS

DEPARTAMENTO DE SOCIOLOGIA

\title{
ALIMENTAÇÃO, MEMÓRIA E IDENTIDADES ÁRABES NO BRASIL
}

Autora: Patrícia Dario El-moor Hadjab

Brasília, 2014 


\section{UNIVERSIDADE DE BRASILIA \\ INSTITUTO DE CIÊNCIAS SOCIAIS \\ DEPARTAMENTO DE SOCIOLOGIA}

\section{ALIMENTAÇÃO, MEMÓRIA E IDENTIDADES ÁRABES NO BRASIL}

Autora: Patrícia Dario El-moor Hadjab

Tese apresentada ao Programa de PósGraduação em Sociologia do Instituto de Ciências Sociais da Universidade de Brasília/UnB, como parte dos requisitos para a obtenção do título de Doutor em Sociologia. 


\author{
UNIVERSIDADE DE BRASILIA \\ INSTITUTO DE CIÊNCIAS SOCIAIS \\ DEPARTAMENTO DE SOCIOLOGIA \\ PROGRAMA DE PÓS-GRADUAÇÃO EM SOCIOLOGIA
}

TESE DE DOUTORADO

ALIMENTAÇÃO, MEMÓRIA E IDENTIDADES ÁRABES NO BRASIL

Autora: Patrícia Dario El-moor Hadjab

Orientadora: Prof ${ }^{a}$ Dr $^{a}$ Mariza Veloso Motta dos Santos

\title{
Banca Examinadora:
}

$\overline{\text { Profa. Dra. Mariza Veloso Motta dos Santos (Presidente) - UnB/SOL }}$

Profa. Dra. Christiane Machado Coêlho - UnB/SOL

Prof. Dr. Edson Silva de Farias - UnB/SOL

Prof. Dr. Roque de Barros Laraia - UnB/DAN

Profa. Dra. Eliane Veras Soares - UFPE/PPGS

Prof. Dr. Marcelo Rosa Carvalho - UnB/SOL (Suplente) 
Ao meu avô João Baptista El-moor (in memoriam) pelo esforço incansável em preservar a história da nossa família $e$ transmitir aos filhos e netos os principais valores que nos definem e nos definirão sempre como árabes. 
"Pertenço a uma tribo que, desde sempre, vive como nômade num deserto do tamanho do mundo."

Amin Maalouf 


\section{AGRADECIMENTOS}

À professora Mariza Veloso Motta dos Santos, pela seriedade e profissionalismo com que se dedicou à orientação desta tese.

A todos os professores e professoras que fizeram parte da minha formação como socióloga, em especial à banca de qualificação do doutorado, pois suas contribuições foram determinantes para o redirecionamento do estudo aqui apresentado.

Aos meus familiares, maior tesouro que eu poderia possuir nesta vida. $\mathrm{O}$ amor e o apoio dos meus pais e irmãs foram determinantes na minha trajetória pessoal e profissional.

Ao meu esposo, grande amigo e companheiro, com quem compartilho o amor à cultura árabe e que esteve ao meu lado nos momentos mais desafiadores dos últimos anos.

Às minhas amadas Pepé (in memoriam) e Lalá, pela alegria de escrever esta tese em meio a tantas peripécias felinas diárias.

À querida Janete Rodrigues, que tive a alegria de conhecer no início do doutorado, por todas as aventuras divididas nesses últimos quatro anos, e cuja amizade espero que dure toda a vida.

A todas as minhas alunas e alunos, pela paciência e compreensão nos momentos em que precisei me ausentar das aulas para me dedicar à pesquisa.

A todos os participantes desta pesquisa, que dividiram comigo um pouco das suas lembranças e histórias.

À querida amiga Fedra Rodríguez, pela leitura final do documento e pela troca constante de informações sobre o tema no último ano.

À querida amiga e aluna Patrícia Vieira, pelo carinho com que se dedicou à revisão do texto e pelas palavras de incentivo, sempre.

Ao Conselho Nacional de Desenvolvimento Científico e Tecnológico (CNPq) pela bolsa de doutorado, que me permitiu reservar alguns anos da minha vida para dedicar-me a um tema que ainda possui muitas lacunas para serem investigadas. 


\begin{abstract}
ABREVIATURAS
ANBA - Agência de Notícias Brasil-Árabe

BIBLIASPA - Biblioteca/Centro de Pesquisa América do Sul - Países Árabes

CCAB - Câmara de Comércio Árabe-Brasileira

EBC - Empresa Brasil de Comunicação

FEARAB - Federação das Entidades Americano-Árabes

ICAB - Instituto da Cultura Árabe Brasileira

ICARABE - Instituto de Cultura Árabe

IMA - Instituto do Mundo Árabe
\end{abstract}




\section{LISTA DE QUADROS E FIGURAS}

Quadro 1 Esquema desenvolvido por Jan e Aleida Assmann.................................... 44

Quadro 2 Data de adesão dos países à Liga dos Estados Árabes............................... 80

Quadro 3 Texto de abertura da página Presença Árabe no Brasil, no Facebook....... 167

Figura 1 A expansão do Islã até o ano 750......................................................... 59

Figura 2 Mapa do al-Andalus, na Península Ibérica, no ano 950, durante o Califado Omíada

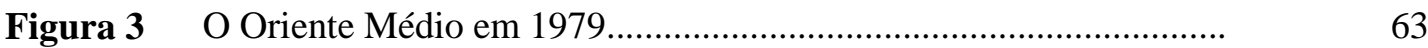

Figura 4 Folheto de divulgação da Exposição D. Pedro II no Líbano .............. 88

Figura 5 Empório sírio e restaurante de comida árabe na Rua Comendador Abdo 94 Schahin

Figura 6 Instrumento musical de origem moura conhecido como Adufe........ 104

Figura 7 Imagem da galeria de fotos do site Presença Árabe no Brasil em Imagens 116

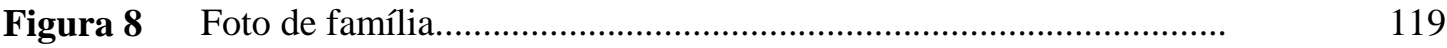

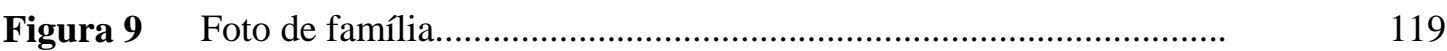

Figura 10 Documento de família......................................................................

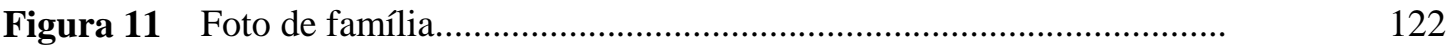

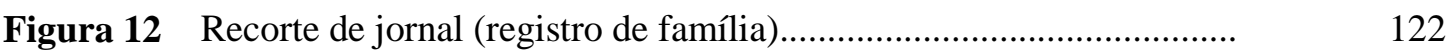

Figura 13 Recorte de jornal (registro de família) ............................................... 123

Figura 14 Registro de evento festivo em um centro cultural árabe em Campo Grande 124

Figura 15 Cemitério Bizantino em Mucugê (BA) ……........................................ 126

Figura 16 Interior da Igreja Nossa Senhora da Conceição em Salvador (BA)........ 127

Figura 17 Algodão, uma das muitas palavras de origem árabe na língua portuguesa 128

Figura 18 A influência dos muxarabis na arquitetura brasileira................................... 129 
Figura 19 Exemplo de divulgação da dança folclórica árabe em Juiz de Fora........

Figura 20 Doces árabes comprados em um empório da Rua 25 de Março

Figura 21 Tradição árabe preservada na forma de cortar a laranja

Figura 22 Comida tradicional: quibe cru com Snoubar.

Figura 23 Doce maranhense decorado na forma de azulejo com inspiração em arabesco.

Figura 24 Alfenim de cana, um dos exemplos da herança árabe na culinária brasileira

Figura 25 Detalhe do exterior da Igreja Ortodoxa São Jorge em Brasília (DF)

Figura 26 Mesquita do Centro Islâmico do Brasil em Brasília (DF).

Figura 27 Fachada do edifício onde está localizado o Instituto de Cultura Árabe Brasileira em Brasília - DF

Figura 28 Mesquita Mohammad Mensageiro de Deus (S.A.A.S.), também conhecida como Mesquita do Brás, situada em São Paulo (SP)

Figura 29 Tela principal da página Presença Árabe no Brasil no Facebook

Figura 30 Exemplo de uma mensagem privada por meio da página Presença Árabe no Brasil, no Facebook

Figura 31 Exemplo de uma mensagem privada por meio da página Presença Árabe no Brasil, no Facebook

Figura 32 Comentários deixados em uma publicação sobre a Palestina na página Presença Árabe no Brasil, no Facebook.

Figura 33 Comentários deixados em uma publicação sobre a Síria na página Presença Árabe no Brasil, no Facebook.

Figura 34 Trecho de uma publicação sobre as variações de receitas de esfirras e quibes já encontradas pelos leitores da página Presença Árabe no Brasil....

Figura 35 Comentários dos leitores sobre uma publicação a respeito de doces árabes 
Figura 36 Comentários deixados em uma publicação sobre o tradicional "pão sírio" na página Presença Árabe no Brasil.

Figura 37 Comentário deixado em uma publicação sobre hábitos e tradições alimentares árabes na página Presença Árabe no Brasil

Figura 38 Comentário feito por um leitor ao compartilhar uma publicação sobre um site de receitas árabes na página Presença Árabe no Brasil.

Figura 39 Comentários sobre a notícia de que o governo do Líbano tenta provar que o falafel é um prato daquele país. 


\section{RESUMO}

Nos últimos séculos, diversas culturas estrangeiras aportaram no Brasil e deram suas contribuições na construção de uma identidade nacional. Entre elas, é possível mencionar a árabe. No entanto, o uso deste termo permite nos referirmos tanto à entrada daqueles imigrantes que desembarcaram no país a partir da segunda metade do século XIX, quanto a uma cultura que foi trazida por meio de hábitos e costumes de portugueses e espanhóis colonizadores após quase oito séculos de influência islâmica na Península Ibérica. A pesquisa realizada para elaboração desta tese transcorreu pautada na investigação das intersecções entre alimentação e sociabilidade e como elas podem evidenciar diferentes gradações de identidades "árabes" na sociedade e cultura brasileiras. O ponto de partida para o estudo foi a ideia de que as tradições alimentares podem ser tratadas como uma importante unidade de análise para se compreender de que formas o Brasil convive com o que se pode chamar de presenças árabes em nosso cotidiano. A alimentação é um forte registro da cultura de um povo, e por meio dela, os imigrantes são capazes de preservar laços sociais, reforçando costumes e conectando-se com parte importante de sua história. A manutenção de certas tradições alimentares foi uma das estratégias adotadas pela comunidade árabe imigrante e descendente como um meio de preservação da identidade vinculada às suas origens. Complementarmente, é possível verificar na cozinha brasileira contribuições que vão além da chegada de sírios e libaneses ao país. Trata-se de uma influência moura, como Gilberto Freyre e Câmara Cascudo costumavam se referir à herança cultural trazida pelos ibéricos, que somadas a muitas outras, contribuíram no processo de caldeamento das nossas matrizes culturais.

Palavras-chaves: Identidades árabes, memória, alimentação. 


\begin{abstract}
In the past centuries, foreign cultures were brought to Brazil and contributed to the construction of a national identity. Among them, it is possible to mention the one of the Arabs. However, the latter refers not only to those immigrants who arrived in the country from the second half of the nineteenth century on, but also to a culture that was embedded in customs and habits of Portuguese and Spanish settlers after eight centuries of Islamic influence in the Iberian Peninsula. The research conducted for the preparation of this thesis was based on investigating the existence of connections between eating habits and sociability and how that could show different levels of "Arabic" identities found in the Brazilian society and culture. The starting point for the study was the idea that food traditions could be dealt with as an important unit of analysis for understanding the ways Brazil coexists with what one might call the Arab presence in the daily life of the people. Foodways are a strong record of the culture of a people, and through them, immigrants are able to maintain social ties, stress the importance of their customs and connect with an important part of their history. The maintenance of certain food traditions was one of the strategies adopted by the community of Arab immigrants and descendants to keep the identity related to their origins. Additionally, it's possible to identify some Brazilian eating habits that were influenced not only by Syrians and Lebanese that came to the country, but also by a Moorish presence, as Gilberto Freyre and Câmara Cascudo would normally refer to the cultural heritage of the Iberians, which, coupled with many others traditions, would contributed to $i$ the melting together of the different cultures that have formed Brazil.
\end{abstract}

Keywords: Arab identity, memory, foodways. 


\section{RESUMÉ}

Lors des derniers siécles, de différentes cultures étrangères se sont établies au Brésil participant de par leur contribution à la construction d'une identité nationale. Parmi cellesci, il est possible de distinguer la culture arabe. Cependant, l'utilisation de ce terme peut aussi bien désigner l'entrée de ces immigrés qui ont débarqué dans le pays depuis la seconde moitié du XIX ème siècle, qu'une culture apportée à travers les us et coutumes des colonisateurs portugais et espagnol, après environ huit siècles d'influence islamique dans la péninsule ibérique. L'enquête menée pour l'élaboration de cette thèse s'est fondé sur la recherche des intersections entre alimentation et sociabilité et comment peuvent-elles mettre en évidence les différentes gradations des identités «arabes » dans la société et la culture brésilienne. Le point de départ en vue de mener cette étude s'est basée sur l'idée que les traditions alimentaires peuvent être traitées comme des unités d'analyse pour comprendre de quelle façon est ce que le Brésil coexiste avec ce que 1'on pourrait qualifier de présence arabe dans notre vie quotidienne. L'alimentation constitue un repère important de la culture d'un peuple, et c'est à travers elle que les immigrants sont en mesure de préserver les liens sociaux, en renforçant les coutumes tout en se connectant avec une partie importante de leur histoire. Le maintien de certaines traditions alimentaires était l'une des stratégies adoptées par les communautés arabes immigrantes et leurs descendants tel un moyen de préserver l'identité liée à leurs origines. En outre, il est possible de vérifier dans la cuisine brésilienne, les contributions qui vont au-delà de l'arrivée des Syriens et des libanais dans le pays. Il s'agit de l'influence mauresque, à laquelle Gilberto Freyre et Câmara Cascudo avaient pour habitude de référer en évoquant le patrimoine culturel hérité des Ibères, qui ajouté à d'autres, ont contribué au processus de fusion de nos matrices culturelles.

Mots-clés: identité arabe, mémoire, alimentation. 


\section{SUMÁRIO}

LISTA DE QUADROS E FIGURAS ......................................................................... VIII

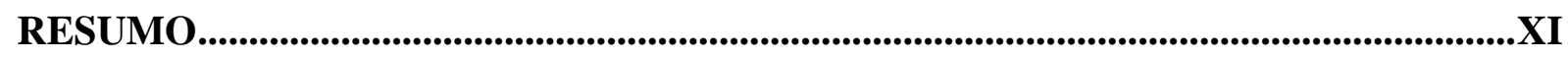

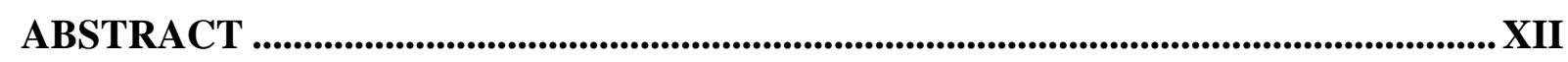

RESUMÉ ...................................................................................................................................XIII

INTRODUÇÃ

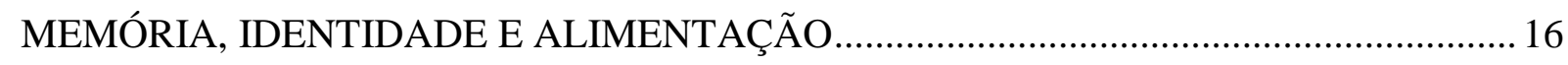

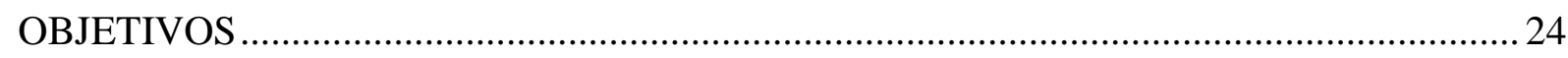

CONSTRUÇÃO METODOLÓGICA DA PESQUISA …...................................................... 25

CAPÍTULO 1 REFERENCIAL TEÓRICO: CONCEITOS QUE NORTEARAM A

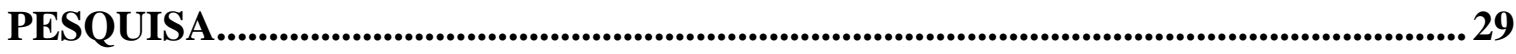

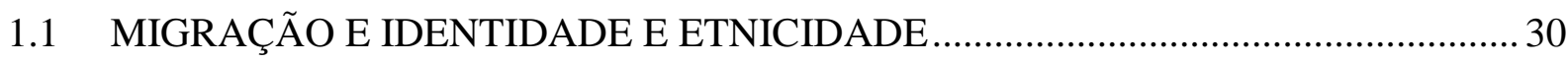

1.2 A MEMÓRIA NAS CIÊNCIAS SOCIAIS ............................................................... 36

1.3 A ALIMENTAÇÃO COMO UM COMPONENTE IDENTITÁRIO........................... 47

1.4 REPRESENTAÇÕES SOCIAIS E A CONSTRUÇÃO DE IMAGINÁRIOS ...............53

CAPÍTULO 2 A CONSTRUÇÃO DE IMAGINÁRIOS E A POLISSEMIA DA

PALAVRA “ÁRABE" ...................................................................................................... 57

2.1 PROBLEMATIZAÇÃO DO CONCEITO: QUEM SÃO OS “ÁRABES” E O ESFORÇO PARA DELIMITAÇÃO DE UM CAMPO DE ESTUDO.......................... 57

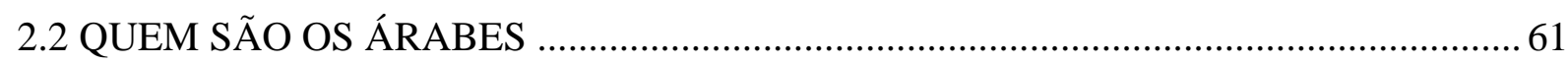

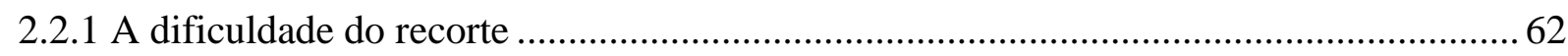

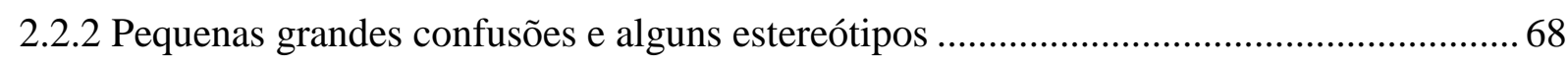

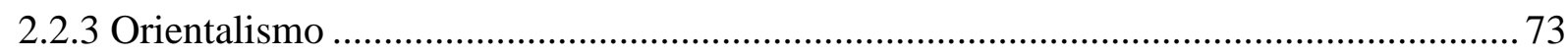

2.2.4 O Nacionalismo Árabe e a minimização das particularidades de cada nação .................. 77

2.3 O MUNDO ÁRABE NO CENÁRIO POLÍTICO A PARTIR DO SÉCULO XX - A

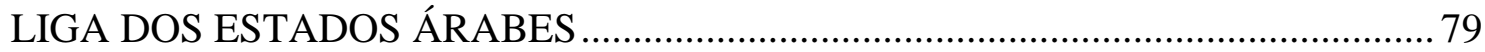

CAPÍTULO 3 A PLURALIDADE DA PRESENÇA ÁRABE NO BRASIL....................... 82

3.1 A PRESENÇA ÁRABE NO BRASIL PELA VIA DA IMIGRAÇÃO .............................. 84

3.2 A PRESENÇA ÁRABE NO BRASIL PELA VIA DA HERANÇA IBÉRICA .............. 101

CAPÍTULO 4 DESCRIÇÃO DOS RESULTADOS: A MANIFESTAÇÃO DAS DIFERENTES PRESENÇAS ÁRABES NO BRASIL E O FENÔMENO DA ALIMENTAÇÃO............................................................................................................113

4.1 O PONTO DE PARTIDA: A PESQUISA EXPLORATÓRIA …................................... 113

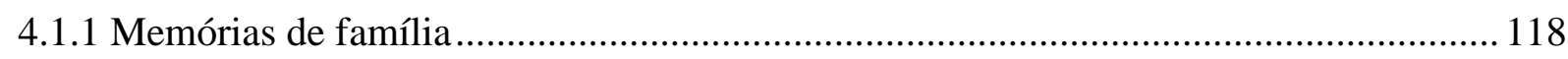


4.1.2 Fotografia e história

4.1.3 O registro de alimentos, hábitos e tradições culinárias árabes no Brasil........................ 130

4.2 AS VISITAS DE CAMPO E AS ENTREVISTAS REALIZADAS .............................. 136

4.2.1 Dados gerais sobre as entrevistas e sobre as visitas de campo ................................... 138

4.2.2 Os pontos em comum observados nas famílias de origem árabe ................................ 141

4.3 A OBSERVAÇÃO PARTICIPANTE EM MEIO VIRTUAL: O USO DAS REDES SOCIAIS COMO FONTE EMPÍRICA DE DADOS PARA A PESQUISA E A DINÂMICA DA PÁGINA PRESENÇA ÁRABE NO BRASIL

4.3.1 A escolha do espaço virtual para observação participante

4.3.2. Assuntos que mais despertaram a participação social nas redes sociais durante a

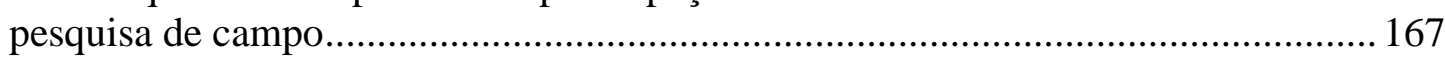

CAPÍTULO 5 ANÁLISE DOS RESULTADOS ............................................................178

5.1 O QUE PESQUISA PERMITIU CONSTATAR ....................................................... 178

5.1.1 Os principais esterótipos e a reflexão sobre a existência ou não de conflitos........... 179

5.1.2 O sentimento de pertencimento à sociedade brasileira ........................................... 184

5.1.3 Presenças árabes, alimentação, memória e identidade ........................................... 189

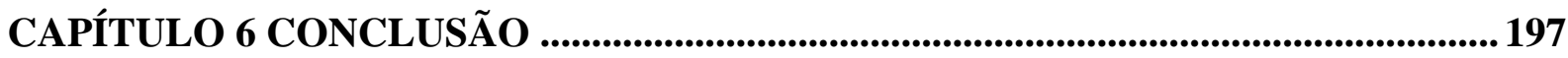

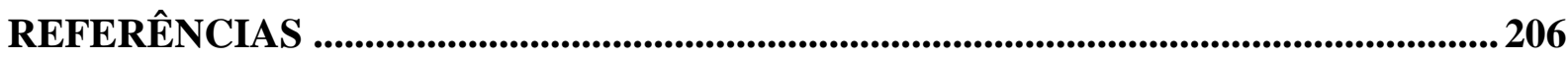

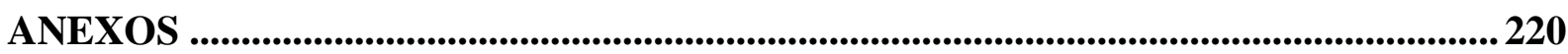

CARTA DE APRESENTAÇÃO DO QUESTIONÁRIO ENVIADO AOS

PARTICIPANTES DA PRIMEIRA ETAPA DA PESQUISA, DE CUNHO

EXPLORATÓRIO, INTITULADA "PROJETO PRESENÇA ÁRABE NO

BRASIL EM IMAGENS"

ROTEIRO DE ENTREVISTA MEDIADA, REALIZADA COM PARTICIPANTES

DA PRIMEIRA ETAPA DA PESQUISA, DE CUNHO EXPLORATÓRIO,

INTITULADA “PROJETO PRESENÇA ÁRABE NO BRASIL EM IMAGENS”. ... 222

SCRIPT BÁSICO PARA REALIZAÇÃO DAS ENTREVISTAS FACE A FACE,

SEMIESTRUTURADAS, REALIZADAS EM BRASÍLIA COM ÁRABES E

DESCENDENTES.

DIVULGAÇÃO DO PROJETO PRESENÇA ÁRABE NO BRASIL EM IMAGENS ........ 225

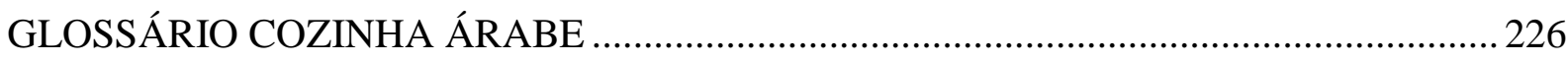




\section{INTRODUÇÃO}

\section{Memória, identidade e alimentação}

Os árabes fazem parte de um grupo de povos que aportaram no Brasil ao longo dos séculos, trazendo diversas culturas estrangeiras e contribuindo para a construção da identidade nacional. Geralmente, quando no país se fala sobre a cultura árabe, é comum fazer referência aos imigrantes (em sua grande maioria, mas não apenas, sírios e libaneses) - que aqui desembarcaram a partir da segunda metade do século XIX. Mas também, e não raro, reconhece-se uma herança cultural que se instalou na forma de hábitos e costumes em portugueses e espanhóis, após quase oito séculos de influência islâmica na Península Ibérica.

Percebe-se que essas distintas "presenças árabes" no Brasil são tratadas por meio de uma pluralidade de enfoques. Não apenas isso, mas a percepção sobre quem sejam os "árabes" varia consideravelmente. De um lado, é possível encontrar um vasto material voltado para os aspectos históricos dos processos migratórios. E, de outro, deparamo-nos com autores que, ao investigarem as principais matrizes culturais do Brasil, chamaram atenção para um tipo de influência árabe, neste caso, anterior aos grandes fluxos migratórios que marcaram os séculos XIX e XX.

Tal influência se deu, dentre tantas formas, pela via da literatura, da filosofia e da ciência. Outrossim, em razão do idioma árabe ter sido uma língua de uso amplo na península ibérica durante algumas centenas de anos, o processo de assimilação também se faz perceptível ao se observar, por exemplo, a vastidão do léxico de origem árabe na língua espanhola e na língua portuguesa. Vale lembrar, por exemplo, que mais de 600 palavras do léxico português (entre elas, muitas das iniciadas pela letra "a") são de origem árabe ${ }^{1}$.

\footnotetext{
${ }^{1}$ Uma discussão específica sobre a questão das diferentes presenças árabes que podem ser reconhecidas no Brasil será apresentada no capítulo 3, que está dividido em duas grandes seções, sendo a primeira (item 3.1) focada no tema da imigração e a segunda (item 3.2) discutirá mais especificamente a herança ibérica, que, indiretamente, promoveu um tipo de influência árabe sobre nossa cultura.
} 
Segundo Abreu \& Aguilera (2010), a longa permanência árabe na Península Ibérica, que se estendeu do século VIII ao século XV, bem como o "refinamento cultural dos muçulmanos em relação aos hispanos, visigodos e cristãos” (2010, p.8), fizeram com que uma série de traços culturais permanecessem na região peninsular, resultantes desse período de contato sociocultural, incluído, particularmente, o linguístico.

A discussão em torno da percepção de possíveis arabicidades na cultura brasileira possui lacunas e carece de estudos que ofereçam maiores reflexões quanto ao seu reconhecimento, tanto do ponto de vista da sua pluralidade, quanto de que forma ela permeia a sociedade, manifestando-se em distintos graus de profundidade.

Na condição de bisneta de libaneses e aluna de graduação do Departamento de Sociologia da Universidade de Brasília, eu tive a oportunidade de realizar, entre 1996 e 1997, um estudo sob orientação do professor Mostafa Amin para elaboração do trabalho de final de curso, o qual tratou sobre a questão da imigração árabe para o Brasil (EL-MOOR, 1997). A pesquisa foi realizada em Brasília e as entrevistas contaram com a participação de imigrantes e descendentes que desembarcaram em outras regiões do país e que posteriormente vieram para a capital federal - como ainda acontece atualmente.

As constatações desta investigação, não apenas estão em consonância com as discussões presentes na atual literatura sobre o tema, como também reforçam a estreita relação entre imigração, memória e alimentação, tema este que será explorado ao longo da tese. Algumas entrevistas obtidas à época em que o estudo foi realizado confirmam essa ideia e sinalizam o que outras referências bibliográficas já reiteraram, ainda que superficialmente. $\mathrm{O}$ trecho a seguir é um dos vários depoimentos registrados naquela ocasião e que apontam nessa direção:

\footnotetext{
"Em síntese, vivemos marcados por aquele espírito forte de família, pela tradição na comida árabe, que as cunhadas faziam muito bem... lembrome muito bem, criança, a minha tia Borbora fazer aquele pão aberto de uma folha apenas, estendidos sobre os braços, em que ela revestia de farinha e ia abrindo pão e assava no fundo de uma assadeira de papel antiga, um tacho de papel antigo [...] Chamo atenção para um fato que também me marcou muito; é simples, mas são coisas que prendem a gente...ela trouxe doces feitos por ela, de frutos dessa propriedade em que
} 
ela residia e em que os avós de minha esposa residiam no Líbano. Trouxe azeitonas, da tal oliveira, que é antiga e ainda frutifica. Trouxe o azeite, ainda virgem, puro, fabricado por ela mesma. Os doces, a azeitona, o azeite, tão presos à nossa tradição, marcou também como um pedaço do Líbano nos nossos dias quando ela nos deu o prazer de estar conosco". J.B.E., filho de libaneses, em entrevista realizada em 1996. (EL-MOOR, 1997, p. 93)

Segundo a maior parte dos imigrantes e descendentes de primeira e segunda geração que foram entrevistados naquela ocasião, as famílias dispunham de poucos mecanismos voltados para a preservação de vínculos com seus países de origem. Os participantes da pesquisa alegavam alguma dificuldade em manter contato com parentes e amigos que ficaram em sua terra natal. E também reconheciam o quão difícil era praticar o idioma em âmbito doméstico, seja por desinteresse dos filhos, seja porque o cônjuge não falava árabe, ou porque, após tantos anos no Brasil já notavam um esquecimento da língua materna.

"Ninguém fala árabe lá em casa...só meu pai. Eu comecei a fazer árabe fiz uma surpresa para ele. Ele ficou muito feliz...." W.A.K.K., filho de palestinos, em entrevista realizada em 1996. (idem)

"Na verdade tenho preocupação sobre meus filhos sobre a língua... a nossa língua de origem. Porque eles estudam na escola portuguesa, estão aprendendo português da forma correta. Falam língua portuguesa da forma correta e estão esquecendo o árabe. Por isso, sempre converso com eles em árabe, dentro de casa com mãe deles pra eles não esquecerem a nossa língua de origem. [...] Eu não estou preocupado em perder os costumes de meu país porque cheguei adulto. Meu medo é meus filhos. Eu não quero que eles fiquem longe dos costumes". A.N., sírio, em entrevista realizada em 1996. (idem)

Apesar de declararem um forte sentimento de pertencimento à sociedade brasileira e reconhecerem o afastamento provocado pela distância em relação a familiares e 
amigos que permaneceram em terras estrangeiras, ao falarem sobre as tradições culinárias e as lembranças de família, os entrevistados sempre se mostravam muito emocionados e revelavam a importância dessa memória na construção de suas identidades.

"Uma coisa permaneceu, eu acho que em todas as casas... foi a comida. A alimentação, a comida árabe ficou em todas as casas. Eu acho que todo mundo hoje sabe pelo menos fazer um quibe, um tahine, alguém sabe fazer isso, alguém da família. Um dos poucos laços que ficou foi esse laço da comida...” J.N., neto de libaneses, em entrevista realizada em 1996. (idem)

"E acho que do ponto de vista da alimentação, pois a alimentação é cultura também eu me sinto bastante influenciada. Pratos, a fartura na mesa, eu acho que esse tipo de coisa é uma característica árabe”. L.M.A., neta de libaneses, em entrevista realizada em 1996. (idem)

A pesquisa realizada entre 1996 e 1997 possuía uma limitação quanto ao alcance de suas conclusões, haja vista que se tratava de um estudo para construção de uma monografia de graduação. Os resultados não permitiram verificar, por exemplo, se as reflexões realizadas naquele momento poderiam ser expandidas para as cidades nas quais o fluxo de imigrantes árabes se mostrou mais intenso. No entanto, na medida em que eram publicados novos estudos sobre a imigração árabe no Brasil, se observava que as constatações podiam ser corroboradas.

As publicações sobre os árabes no Brasil permitem verificar um enfoque dado primordialmente aos seguintes temas: (i) a vinda de sírios e libaneses que deixaram suas terras quando elas ainda estavam sob domínio Otomano²; (ii) a recente imigração árabe,

\footnotetext{
${ }^{2}$ Até meados do século XX, Líbano e Síria possuíam histórias não muito diferentes. Ambos os países faziam parte da região chamada de "A Grande Síria" desde que os turco-otomanos conquistaram o Líbano em 1516 e fizeram do país parte desse império que desapareceu após a derrota da Turquia na Primeira Guerra Mundial. O Líbano permaneceu sob domínio temporário da França, que concedeu a independência definitiva ao país em 1943, sendo que as tropas francesas se retiraram em 1946. Ainda assim, os países
} 
que se deu especialmente por libaneses que deixaram seu país durante a guerra civil que se instalou entre 1975 e 1990, e palestinos, que também vieram em momentos distintos ${ }^{3}$; (iii) o peso da questão religiosa nos processos de adaptação dos imigrantes; (iv) as contribuições dos mascates e comerciantes árabes para o desenvolvimento econômico no interior do país; e, por fim, e em menor frequência, (v) o reconhecimento de uma presença árabe no Brasil especialmente no processo de caldeamento das nossas matrizes culturais.

Observou-se que, desde a publicação do livro que por muito tempo foi considerado uma das maiores referências sobre o assunto - Imigração Árabe 100 Anos de Reflexão (HAJJAR, 1985) - um rol de assuntos relevantes ainda não foram tratados com a fundura devida. E, entre eles, a questão da alimentação e como ela se relaciona com a memória e a identidade árabe no Brasil. Neste sentido, mesmo já passados mais de 10 anos desde a realização do estudo para minha conclusão de curso, pude constatar que a relação entre alimentação e memória de imigrantes árabes (neste caso, libaneses) no Brasil merecia ser aprofundada.

Complementarmente, outras reflexões contribuíram para avigorar o desejo de investigar a fundo esta relação. Entre elas, a exibição de um episódio sobre a imigração libanesa no âmbito da série Chegados, apresentado em 2007 pelo canal televisivo brasileiro Futura. A produção era composta de 13 documentários de 30 minutos em que se

possuem suas particularidades. Provavelmente, um dos discursos que reforçam a diferença entre sírios e libaneses é que estes últimos costumam ressaltar a sua origem fenícia, pois já antes de 2000 a.C.os fenícios se estabeleceram na região onde hoje é o Líbano, construindo um imenso império mercantil com entrepostos comerciais no norte da África, Sicília e a Península Ibérica. Em 64 a.C. o império romano ocupou a região e nessa época o Cristianismo começou a ser praticado. Mesmo com a expansão do islamismo que, já no século IX estava difundido por quase todo o Oriente Médio e norte da África, o Líbano permaneceu com uma forte presença cristã, tendo, inclusive, recebido bem os soldados cruzados franceses que chegavam da Europa para combater o Islã.

${ }^{3}$ Primeiro chegaram os cristãos que, no final do século XIX também desejavam libertar-se do jugo otomano e, posteriormente, a fase mais conhecida que corresponde à Al Nakba (que significa catástrofe, em árabe) e coincide com a criação do Estado de Israel e a expulsão de milhares de palestinos de seus lares. 
abordava o tema da imigração e da identidade na formação do Brasil Contemporâneos 4 . Sobre este programa a respeito do Líbano, Santa Cruz (2007) chamou atenção para o fato de que uma das entrevistadas afirmava categoricamente que é por meio da culinária que a cultura está mais viva.

[...] uma das entrevistadas é a chefe de cozinha Leila Youssef, que mostra na tela a preparação dos pratos, ao mesmo tempo em que relembra como sua mãe fazia o preparo das mesmas comidas e afirma que a língua é um instrumento forte de transmitir a tradição de uma cultura, mas que é na culinária que esta cultura está mais viva (idem, p. 188) ${ }^{5}$.

Também influenciou na decisão de se pesquisar o tangenciamento entre os temas alimentação, memória e identidade árabe o conjunto de fotografias que compõem o acervo permanente da exposição AMRIK: Presença Árabe na América do Sul, concebida e organizada pelo Ministério das Relações Exteriores brasileiro na ocasião da $1^{\text {a }}$ Cúpula Países Árabes - América do Sul, projeto no qual tive oportunidade de atuar como consultora entre 2005 e 2006.

Essa exposição reuniu o trabalho de 23 fotógrafos do Brasil, Venezuela, Colômbia, Peru, Equador, Bolívia, Chile, Argentina, Uruguai e Paraguai, que retrataram as influências árabes em todos os âmbitos da vida quotidiana do subcontinente. As fotografias apresentam um mosaico de evidências emblemáticas do encontro das civilizações árabe e sul-americana, que ajudou a moldar a identidade sul-americana e hoje propicia as bases para aprofundar as relações entre as duas regiões. Depois da cúpula, ela percorreu cidades como Quito, Bogotá, Nova York, Argel, Assunção, Madri e Cairo e, em 2009, foi doada

\footnotetext{
${ }^{4}$ Paula Cosenza e Tuca Paoli, diretoras do programa, concluíram, em suas pesquisas, que 72 etnias estrangeiras ajudaram a compor o povo brasileiro. Disponível em: http://oglobo.globo.com/cultura/chegados-do-futura-vai-contar-historias-dos-imigrantes-que-formarambrasil-4188504\#ixzz2jCal2VMI. Acesso em: 15 jan. 2014.

${ }^{5}$ Série produzida por Bossa Nova Films. Os episódios trouxeram entrevistas com imigrantes dos seguintes países: Japão, Portugal, Itália, Rússia, França, Alemanha, Chile, Moçambique, China, Polônia, Hungria, Armênia e Líbano, http://www.bossanovafilms.com.br/portifolio/chegados.
} 
pelo governo brasileiro ao Instituto de Estudos Hispano-Lusófonos, para compor o acervo permanente da Universidade Mohammed V - Agdal, no Marrocos.

A análise atenta das fotos contidas no catálogo da mostra AMRIK permitiu verificar que a comida e os hábitos alimentares oferecem pistas para se compreender melhor a abrangência e a diversidade da influência da cultura árabe no Brasil. De forma analítica, é possível dividir os registros fotográficos ligados ao tema da comida em dois grupos. O primeiro deles indica a percepção dos fotógrafos quanto à herança árabe via Península Ibérica, que é antiga e está intrínseca à própria formação da uma dita identidade nacional.

De fato, imagens revelam presenças árabes em diferentes nuances em nosso dia a dia, por meio de hábitos e costumes já incorporados na vida do brasileiro. Essa influência não está ligada necessariamente (e apenas) aos deslocamentos e processos migratórios, mas sim à ocupação muçulmana na Europa por quase 800 anos, a qual deixou, para portugueses e espanhóis, marcas profundas em sua culinária, tais como o gosto pelo café, o sabor marcante de suas especiarias, a variedade de carnes, grãos e nozes, como bem revelam os estudiosos Gilberto Freyre e Câmara Cascudo.

Ainda dentro deste acervo, o outro grupo de imagens aponta para um tipo de presença árabe diferente, intrinsecamente associada à chegada de sírios, libaneses e palestinos que vieram em fluxo constante para o Brasil a partir do final do século XIX. Povos que correspondem a uma parte do conjunto países que atualmente compõem o mundo árabe.

Partindo da compreensão de que falar sobre os árabes no Brasil é se referir a inúmeras manifestações sócio-históricas e culturais, a pesquisa aqui apresentada procurou elencar quais aspectos da materialidade da vida permitem reconhecer tal presença. Como ponto de partida, buscou-se identificar os principais dispositivos de preservação da identidade transmitidos por imigrantes aos seus descendentes e que, paulatinamente, teriam sido incorporados na forma de tradições e hábitos em nossa própria cultura.

Os clubes sírios e libaneses, as associações islâmicas de beneficência e as academias de dança oriental, mostraram-se bastante presentes no cotidiano brasileiro. Complementarmente, observou-se que o vestuário, a música, os comportamentos religiosos e também a língua portuguesa foram impregnados por algum tipo de influência árabe. 
Entretanto, do rol de costumes identificados, aqueles ligados à alimentação foram os que me despertaram maior inquietude, pois pareciam revelar os distintos momentos de diálogo travados entre a cultura brasileira e a árabe.

Essa influência não se nota apenas pela popularidade da cozinha árabe, confirmada pelo número impressionante de estabelecimentos alimentícios existentes tanto nas grandes cidades quanto no interior do país. Desperta enorme atenção o fato de o brasileiro ter incorporado ao seu dia a dia alimentos, temperos, formas de preparo e paladares sabidamente árabes. O popular café, presença quase obrigatória nos cafés da manhã do brasileiro, tem sua palavra originada no árabe qahwa (que significa "vinho").

Embora seja proveniente da Etiópia, difundiu-se pelo mundo muito em razão da importância que a planta passou a ter entre os árabes ${ }^{6}$, responsáveis por popularizar seu cultivo. A pimenta síria ( $b a$-har), que nada mais é do que uma mistura de especiarias, entre elas a pimenta Jamaica, pimenta-do-reino preta, canela, cravo e noz-moscada, está disponível nas prateleiras dos supermercados brasileiros e seu uso já é bastante popularizado.

Tampouco inexiste qualquer surpresa ao ver nas vitrines das lanchonetes brasileiras as mais variadas versões de quibes e esfirras, alimentos quase tão conhecidos e apreciados quanto, por exemplo, um pão de queijo mineiro. A forte e sobressalente presença sírio-libanesa no país, em comparação a outras levas migratórias de origem árabe, pode ser sentida, por exemplo, pela vastidão de comércios, mercearias, lanchonetes e restaurantes em todo o país que, mesmo não sendo voltados exclusivamente para a venda de comida árabe, quase sempre oferecem iguarias como as mencionadas anteriormente em

\footnotetext{
${ }^{6}$ FRANCIS, John K.. Coffea arabica L. RUBIACEAE Factsheet of U.S. Department of Agriculture, Forest Service. Disponível em:

http://www.fs.fed.us/global/iitf/pdf/shrubs/Coffea\%20arabica.pdf\#search=\%22\%22Coffea\%20Arabica\%22\% 20native\%22. Acesso em: 12 ago. 2014.
} 
seus cardápios, além do famoso pão sírio, sempre disponível nos balcões das padarias e supermercados ${ }^{7}$.

A pesquisa foi conduzida com enfoque na investigação das diferentes presenças árabes no Brasil e na busca de hábitos e tradições que indicassem, de um lado, processos de construção (e reconstrução) de identidades de imigrantes e descendentes e, de outro, traços imemoriais que permitissem identificar um tipo de influência na construção da nossa identidade nacional. E, como será apresentado ao longo da tese, as tradições culinárias revelaram-se um importante dispositivo de preservação da memória dos imigrantes e descendentes, ao estabelecer um sentimento de pertencimento e de identidade, possibilitando a preservação de laços sociais e da sua própria história. Mas também, revelaram que o Brasil ainda é influenciado por resquícios ainda mais longínquos, que nos remetem, como alguns autores outrora se empenharam em demonstrar, à presença moura como uma das culturas formadoras da nossa identidade nacional.

Ao partir da ideia de que as tradições alimentares podem ser tratadas como uma importante unidade de análise para se compreender de que formas o Brasil convive com o que poderíamos chamar de presenças árabes em nosso cotidiano, espera-se que a pesquisa possa contribuir, não apenas para o fortalecimento do debate sobre a relação entre memória, alimentação e identidade, mas também lançar uma nova luz à investigação da influência de uma cultura estrangeira no Brasil e como ela impacta material e imaterialmente a sociedade brasileira.

\section{Objetivos}

O principal objetivo da pesquisa aqui apresentada foi verificar como hábitos e tradições alimentares se configuram em um importante mecanismo de construção e reconstrução de identidade de uma cultura estrangeira em sua sociedade receptora, mais especificamente, a "árabe".

${ }^{7}$ É sabido que pessoas de origens diversas, como Iraque, Egito, entre outros, também desembarcaram no país. Porém, ao analisar os hábitos alimentares do brasileiro, é bastante perceptível o peso que sírios e libaneses tiveram sobre nossa história, se compararmos com imigrantes árabes de outros países. 
Como objetivos secundários, pretendeu-se ainda:

a. Por meio da análise de hábitos e tradições alimentares, verificar a existência de múltiplas presenças árabes no Brasil, as quais podem ser atribuídas, grosso modo, a duas nascentes distintas, porém não excludentes: (i) a herança islâmica dos povos ibéricos, arraigada em nossa cultura, e; (ii) a convivência com imigrantes árabes, em sua maioria, sírios e libaneses, que começou na última década do século XIX e se estende até os dias atuais.

b. Dar início a um processo de investigação quanto ao imaginário construído na sociedade a respeito de quem são os "árabes" e como as representações sociais criadas em torno desse conceito podem propiciar, minimizar ou evitar situações de conflito étnicos.

c. Problematizar o uso da palavra "árabe" e propor um exercício de melhor delimitação do objeto ao se falar sobre um universo tão amplo como esse em investigações de cunho sociológico.

d. Investigar e existência de conflitos e situações de discriminação ou intolerância envolvendo os imigrantes de origem árabe no Brasil e propor formas de pensar o multiculturalismo como um dos caminhos para combater os preconceitos e discriminações ligados a diferenças étnico-religiosas.

\section{Construção metodológica da pesquisa}

A pesquisa realizada para elaboração desta tese transcorreu pautada na investigação das intersecções entre alimentação e sociabilidade e como elas podem evidenciar diferentes gradações de identidades "árabes" na sociedade e cultura brasileiras. Aqui, o estudo de hábitos e tradições alimentares se firmou como um corpus empírico bastante promissor e com infinitas possibilidades de captação destas práticas de significação, dentre as quais podemos citar a memória coletiva, enfatizando especialmente o sentimento de pertencimento, além da constituição de uma identidade nacional envolvidos.

Dentro desse contexto, optou-se por investir na condução de uma pesquisa qualitativa e exploratória, orientada dentro de uma perspectiva fenomenológica, haja vista 
a compreensão de que a realidade investigada não é tida como algo objetivo e passível de ser explicado por meio de uma única maneira, mas sim, que pode e deve ser interpretada, comunicada e compreendida.

O método compreensivo de base fenomenológica propõe um esforço em sistematizar dados de natureza qualitativa e possibilita ao investigador compreender de que forma é a vida, o pensamento e as experiências das pessoas envolvidas com o objeto investigado a partir de suas próprias expressões pessoais.

Como base principal para delineamento do trabalho de campo nesta pesquisa, é possível citar o austríaco Alfred Schutz, que também se tornou conhecido como uma importante figura da Escola de Chicago e referência no pensamento fenomenológico ainda que não tenha sido o primeiro pensador a tentar realizar uma síntese geral do que seria uma Sociologia baseada em considerações fenomenológicas. ${ }^{8}$ A Fenomenologia preocupa-se com aquela realidade cognitiva que está incorporada nos processos das experiências humanas subjetivas. (SCHUTZ, 2012, p. 24)

A gênese do método investigativo qualitativo nos remete à Alemanha do século XIX, mais especificamente à necessidade experimentada pelas ciências sociais naquele momento de se averiguar fenômenos humanos por meio de um novo tipo de abordagem que permitisse ir além da "simples" descrição de comportamentos humanos (QUEIROZ et al., 2007, p. 276). Ressalta-se que o pressuposto principal desse método está na possibilidade de extrapolar os padrões formais de pesquisa e tratar as incertezas como parte de sua epistemologia. Ressaltam-se também as características multimetodológicas a que podemos recorrer, utilizando um número variado de técnicas e instrumentos de coleta de dados. Esse formato qualitativo de levantamento de dados permitiu maior solidez na construção da base de informações.

Recorrendo a Pollak (1989, p. 7), para quem a memória está integrada em "tentativas mais ou menos conscientes de definir e de reforçar sentimentos de

\footnotetext{
${ }^{8}$ Cabe acrescentar que dentre os autores que criaram as bases da fenomenologia estão o filósofo alemão Edmind Husserl, o filósofo francês Henri Bergson e o estadunidense William James, um dos fundadores da psicologia moderna e importante filósofo ligado ao Pragmatismo.
} 
pertencimento e fronteiras sociais entre coletividades de tamanhos diferentes ${ }^{9}$, , acredita-se que esses recursos empíricos pautados no levantamento de impressões e percepções pessoais e coletivas sobre as diferentes presenças árabes no Brasil, permitiram propor um novo olhar sobre as identidades e discursos acerca dessas chamadas influências.

A pesquisa teve início em novembro de 2011 com uma etapa exploratória, a qual se caracterizou pela criação de uma galeria de imagens que refletiam, segundo a opinião de voluntários, exemplos da(s) presença(s) árabe(s) no Brasil. Esse primeiro momento, que será detalhado adiante, foi determinante porque apontou para a importância de se considerar a força da relação entre comida e cultura árabe em território brasileiro. Ademais, permitiu que as etapas seguintes da investigação fossem delineadas.

Essa galeria de imagens foi construída a partir da participação de 43 pessoas espalhadas por todas as regiões do Brasil (mas também fora do país) no período de novembro de 2011 a novembro de 2012 e permitiu verificar, entre outros aspectos, uma forte tendência de se ressaltar aspectos ligados a hábitos e tradições alimentares árabes incorporados ao cotidiano do brasileiro. Passado um ano desde a realização do estudo exploratório, iniciou-se uma nova etapa investigativa, a qual teve o intuito de aprofundar essa constatação e captar melhor as impressões, representações e percepções das pessoas a respeito do tema estudado.

Essa nova etapa, embora tenha sido inicialmente focada no Distrito Federal, posteriormente contou com participação de pessoas residentes em outras cidades, o que enriqueceu sobremaneira o estudo e possibilitou verificar a recorrência de respostas e impressões sobre o tema pesquisado em várias cidades brasileiras. Também nessa etapa, que se estendeu até março de 2014, foi elencado um conjunto de instrumentos adotados para levantamento de dados, listados a seguir segundo ordem de realização ao longo da pesquisa:

1. Análise de documentos e fotografias;

\footnotetext{
${ }^{9}$ Como exemplos dessas coletividades é possível citar partidos, sindicatos, igrejas, aldeias, regiões, clãs, famílias, nações, entre outros.
} 
2. Entrevistas individuais na modalidade "mediada" (via e-mail ou conversa em tempo real através de ferramentas virtuais que permitem este tipo de interação);

3. Entrevistas individuais na modalidade "face a face" semiestruturadas;

4. Observação participante em instituições culturais, religiosas e alimentícias no Distrito Federal relacionadas - direta ou indiretamente - ao mundo árabe, tais como Instituto Cultural Árabe de Brasília, Mesquita, Igreja Ortodoxa, Restaurantes de comida árabe;

5. Observação participante virtual em uma comunidade virtual criada especialmente para possibilitar maior contato por parte da autora com árabes e descendentes residentes tanto no Distrito Federal, quanto em outras cidades, ao longo da pesquisa.

Essa última etapa de levantamento de dados foi concebida a partir de premissas construídas no âmbito da etnografia digital. A etnografia é um método de investigação oriundo da Antropologia que reúne técnicas que permitem ao pesquisador um trabalho de observação, a partir da inserção em comunidades, onde a investigação possibilita maior contato intrassubjetivo com o objeto de estudo (AMARAL et al, 2008). Ao fazer uso da metodologia etnográfica para o estudo de práticas culturais mediadas por computador, estamos partindo da premissa de que é possível também observar e interpretar a cultura de grupos sociais, buscando insights culturais genuínos por meio de coleta e análise qualificada das interações sociais nas mídias sociais e dos conteúdos compartilhados online. Sobre este tipo de abordagem, alguns autores costumam referir-se, embora o termo não seja consensual, como Netnografia, palavra originalmente cunhada por Robert Kozinets (2002) no final dos anos 90. Para ele, "o pesquisador, quando vestido de netnógrafo, transforma-se num experimentador do campo, engajado na utilização do objeto pesquisado enquanto o pesquisa".

Todas as etapas da pesquisa serão descritas de forma detalhada no capítulo destinado à apresentação dos dados, o qual trará os principais resultados encontrados no conjunto das técnicas utilizadas. No entanto, esse capítulo será precedido de outros três, igualmente importantes e de natureza teórica: (i) um, em que serão aprofundados conceitos teóricos centrais que permitiram o avanço deste estudo; (ii) em seguida, se discutirá a polissemia da palavra árabe, as suas nuances e as conotações sociais, religiosas e políticas identificadas e, por fim, (iii) as diferentes presenças árabes no Brasil serão tratadas em duas vias principais, a da imigração e a da herança ibérica. 


\title{
CAPÍTULO 1 \\ REFERENCIAL TEÓRICO: CONCEITOS QUE NORTEARAM A PESQUISA
}

\begin{abstract}
Neste capítulo estão destacados os temas considerados norteadores para construção desta pesquisa. Embora inicialmente a investigação não tenha iniciado com a intenção clara de abordar a relação entre memória, identidade e hábitos alimentares em torno da(s) presença(s) árabe(s) no Brasil, o aprofundamento da bibliografia consultada, somado aos resultados da pesquisa exploratória realizada na primeira etapa de levantamento de dados, indicou a importância em debruçar-me sobre a temática da alimentação, ainda pouco trabalhada dentro da perspectiva da imigração árabe no Brasil e de uma influência árabe pela via da herança ibérica em solo sul-americano.
\end{abstract}

Diante dessa constatação, as informações levantadas apontaram de forma bastante incisiva para alguns temas que, posteriormente, se mostrariam correlacionados:

•Alimentação,

-Memória,

-Identidade,

-Sentimento de pertencimento,

•Construção de imaginários.

Falar sobre a presença de uma cultura estrangeira em uma sociedade - seja ela qual for - é tratar da memória coletiva de um ou vários grupos. Quando este grupo é formado por várias gerações de imigrantes, é imprescindível pensar em como as lembranças foram registradas, processadas, transmitidas e legitimadas, tanto por este grupo, quanto pela sociedade receptora.

Uno de los recuerdos más punzantes que tengo de mí padre es verlo sentado en el balcón de su casa, leyendo uno de esos artículos, publicado en el diario al-Nahar, de Beirut. Recuerdo que él convocó a toda la familia para abrirlo, como si fuese una ceremonia solemne. Fue la primera vez que lo vi llorar, sin alarde: un llanto silencioso de un dolor inaudito. En aquel momento, al mirar a ese hombre viejo que un día sería 
enterrado en un lugar muy distante de su patria, pensé en el dolor de los inmigrantes, de los exilados y de los expatriados que difícilmente retornan a su tierra natal para volver a ver a parientes y amigos, o simplemente para contemplar el paisaje de la infancia, cuando todos los demás estén muertos. Pensé que una sociedad, cualquiera que sea, debe alguna cosa a esos seres extraviados: hombres y mujeres que, movidos por la voluntad de vivir una vida menos penosa o por un deseo insano de sobrevivir, aunque sea como almas en pena, eligen otra patria cultural (HATOUM, 2009, p. 444). ${ }^{10}$

\subsection{Migração e identidade e etnicidade}

Entre os séculos XIX e XX, os intensos deslocamentos globais seguiram padrões e volumes nunca antes vistos (FAZITO, 2005, p. 46), trazendo para as ciências sociais uma nova preocupação acerca da questão da imigração. Pode-se dizer que, paralelamente, o tema alcançou também outras áreas tais como a História, a Demografia, a Geografia e as Relações Internacionais, entre outras. Preocupação essa que se mostra cada vez mais intensa, a julgar pelas recentes pesquisas e iniciativas focadas nessa temática.

Patarra (2006, p. 7) afirma que “a crescente importância das migrações internacionais no contexto da globalização tem sido objeto de um número expressivo de contribuições importantes, de caráter teórico e empírico, que atestam sua diversidade, seus significados e suas implicações". Entretanto, muito embora a questão da migração esteja

\footnotetext{
${ }^{10}$ Uma das lembranças mais tristes que eu tenho do meu pai é ele sentado na varanda de sua casa, lendo um desses artigos, publicado no jornal al-Nahar, Beirute. Lembro-me que ele chamou toda a família para abrilo, como se fosse uma cerimônia solene. Foi a primeira vez que o vi chorar sem alarde: um grito silencioso de dor inédito. Naquele momento, olhando para o velho homem que um dia seria enterrado bem longe de sua pátria, eu pensei sobre a dor dos imigrantes, dos exilados e dos expatriados que dificilmente retornarão à sua terra natal para ver de novo parentes e amigos, ou apenas para ver a paisagem da infância, quando todo mundo estiverem mortos. Eu pensei que uma sociedade, qualquer que seja, deve alguma coisa a estes seres perdidos, homens e mulheres que, movidos pelo desejo de viver uma vida menos dolorosa ou por um louco desejo de sobreviver, mesmo que seja como almas em sofrimento, escolhem outra pátria cultural.
} (HATOUM, 2009, p. 444) 
recebendo crescente atenção nas últimas décadas, não é possível afirmar que existe um consenso na literatura voltada para essa temática, seja ela de natureza demográfica, sociológica ou econômica, especialmente quando se trata em fundamentar daquilo que vem a constituir empiricamente um movimento migratório.

De fato, a década de 1990 produziu relevantes estudos sobre o tema, a citar como exemplo, o trabalho dos sociólogos Stephen Castles e Mark Miller que teriam sugerido, em seu livro The Age of Migration estarmos vivendo na era das migrações. Para Castles \& Miller (1998), temas como diversidade étnica, racismo, e multiculturalismo devem ser tratados de forma conjunta como efeito da distinção entre a população receptora e a população imigrante, frequentemente vista como "estrangeiro" ou "quase cidadão". Ainda, os autores salientam que a "migração internacional é frequentemente causa e efeito de várias formas de conflitos e não um fenômeno isolado". Segundo Castles \& Miller (2009, p. 20), o estudo da migração internacional normalmente é direcionado para dois formatos distintos de investigação científica. De um lado destacamos a pesquisa sobre quais os determinantes, os processos e os modelos de migração. Do outro, seguem os estudos sobre as formas pelas quais os migrantes se integram, ou são incorporados pelas sociedades receptoras. No entanto, para estes autores, esta divisão é artificial e prejudica a compreensão do processo migratório como um todo. A solução, segundo eles, seria investir em estudos migratórios de uma forma que abarque ambos os lados das investigações.

A pesquisa sobre migração é intrinsecamente multidisciplinar: Sociologia, Antropologia, Ciência Política, História, Economia, Geografia, Demografia, Psicologia, Estudos Culturais e de Direito, abordam diferentes temáticas. Os autores apresentam um dado que indica que em 2000, $97 \%$ da população mundial, embora não fosse de migrantes internacionais, tinham suas vidas afetadas de alguma forma pela migração. As mudanças, no entanto, são sempre muito mais percebidas por parte de quem migra, pois perpassam por todas as etapas do processo migratório, desde a saída de seus países de origem, o trânsito e o destino.

Os autores chamam atenção para o fato de que estudos pautados em grandes bases de dados, com base quantitativa, normalmente costumam focar em questões diferentes das pesquisas com amostras menores. Cada qual dos métodos possui sua importância, afirma Richmond (apud Assis \& Sasaki, 2000, p. 2), que, "ao analisar os 
clássicos - Malthus, Marx, Durkheim e Weber - demonstrou que a migração era analisada enquanto consequência do processo de desenvolvimento do capitalismo, assim como os processos de industrialização e urbanização".

Se, para Thomas Malthus, economista e demógrafo inglês, a questão da migração deveria ser tratada como uma consequência (inevitável) relacionada ao problema da superpopulação, para Marx, embora o tema não fosse sua preocupação central, a concentração de capital estaria atrelada à concentração humana. Neste sentido, o pensamento marxista fazia referência às grandes migrações que marcaram o desenvolvimento do capitalismo: (i) a concentração industrial em determinadas regiões urbanas, (ii) o desenvolvimento dos meios de transportes, os quais possibilitaram um aumento no deslocamento humano em grandes levas; ou (iii) a desestruturação da economia camponesa, que ocasionou a migração de um grande contingente de camponeses sem terra ou trabalho em direção às nascentes cidades industriais.

Para Émile Durkheim, o tratamento da imigração era no sentido de que este processo indicava um tipo de anomia. O sociólogo admitia que este era um dos fatores de quebra das comunidades tradicionais mantidas juntas pelos laços de solidariedade mecânica. Em outras palavras, a migração poderia ser tomada como uma das causas da quebra das comunidades tradicionais, mantidas pela solidariedade mecânica. Em última instância, a quebra de valores ocasionaria um tipo de desordem social, o que possibilitaria, consequentemente, o aumento do crime, do suicídio e do conflito de grupo. Max Weber tampouco focou suas análises na questão da migração, que era percebida como algo secundário. Para o pensador alemão, a migração era um fator incidental, que possibilitaria a criação de novas classes sociais e grupos de status étnicos.

No entanto, em que pese a imigração não ter sido assunto central entre os "fundadores" da sociologia, o tema apareceu com certa força na obra de Georg Simmel, para consolidar-se posteriormente nos estudos desenvolvidos na chamada Escola de Chicago, nas primeiras décadas do século XX. É possível falar de imigração em Simmel a partir de seus escritos sobre os judeus (que ele considerava assimilados) na Europa. Por outro lado, quando autor alemão fala sobre a questão do espaço, pode-se ver também uma discussão sobre a mudança de lugares e, em última instância, sobre as migrações. 
Porém, a obra de Simmel refere-se especificamente aos migrantes quando o autor fala sobre os estrangeiros, uma figura social que oscila entre o distante e o próximo. Em "O Estrangeiro", o autor define aquele que se fixou em um grupo espacial particular, mas sua posição naquele contexto é determinada, essencialmente, pelo fato de "não ter pertencido a ele desde o começo, pelo fato de ter introduzido qualidades que não se originaram nem poderiam se originar no próprio grupo" (SIMMEL, 2005, p. 182). ${ }^{11}$

Em parte sob grande influência do pensamento simmeliano, a chamada primeira geração da Escola de Chicago ${ }^{12}$, realizou inúmeros estudos a partir de variados temas relacionados à questão da modernidade e seus impactos nas grandes cidades. Daí, a realização de pesquisas sobre imigração, pobreza, marginalidade, entre outros. Alguns teóricos pertencentes àquela corrente intelectual debruçaram-se sobre estudos relacionados à (des)integração social e a assimilação cultural dos imigrantes.

Posteriormente, termos específicos para tratar a questão da migração seriam propostos por alguns teóricos ligados ao departamento de sociologia da Escola de Chicago, vindo a se tornar com o passar do tempo, questionáveis (e refutados) no âmbito dos estudos sobre deslocamentos humanos. Entre eles, o melting pot - em que o imigrante gradativamente seria integrado à sociedade de destino com a consequente assimilação da cultura e valores do lugar; sem, no entanto, significar uma perda total de seus valores e modo de vida originais, nasceram nesse contexto, entre estudiosos e acadêmicos da tão famosa escola ${ }^{13}$.

${ }^{11} \mathrm{O}$ texto foi originalmente escrito em alemão em 1908.

12 Nome pelo qual se tornou conhecido um grupo de acadêmicos ligados ao departamento de sociologia da Universidade de Chicago.

${ }^{13}$ Merece menção o fato de que a Universidade de Chicago foi fundada em 1892, a partir de uma grande doação feita pelo milionário norte-americano John Davison Rockefeller e começou com um pequeno número de professores, entre eles, Albion Woodbury Small (1854-1926), docente de Sociologia e chefe do primeiro Departamento de Sociologia dos Estados Unidos. A intenção, naquela ocasião, era investir na formação de alunos segundo o modelo alemão, produzindo doutores e criando um grupo de professores que saíssem pelo país afora ensinando a ciência sociológica. A importância de Small se deve, entre outras coisas, ao fato de ele ter sido o responsável pela criação do primeiro periódico de Sociologia dos Estados Unidos, o American Journal of Sociology - que começou a ser editado no início do século XX e se encontra 
A chamada primeira geração da Escola de Chicago se tornou conhecida, entre várias razões, pelos variados temas das pesquisas que eram ali promovidas, as quais visavam comunidades de imigrantes, questão da pobreza, bem como outros assuntos ligados à vida nas grandes cidades, entre elas, Chicago. Indubitavelmente, sua fama também está relacionada ao pensamento pragmático presente nos pesquisadores que, de uma forma ou de outra, tiveram contato com este movimento filosófico, notadamente de origem norte-americana ${ }^{14}$.

Segundo Assis \& Sasaki (2000), no final do século XX, o interesse pelos fenômenos migratórios foi marcado por análises econômicas e os estudos tornaram-se mais macrossociológicos, dedicados às análises cada vez mais pautadas em métodos quantitativos, com uma forte ênfase no indivíduo migrante, mais do que nas suas relações sociais. Nesse caso, segundo as autoras, "o campo da Sociologia desloca sua fronteira para as proximidades da Economia, distanciando-se um pouco da História e da Psicologia Social, que influenciaram muito os estudos dos funcionalistas e da própria Escola de Chicago".

ativo até os dias atuais, sendo uma das maiores publicações relacionadas à Sociologia do mundo. Assim como muitos dos primeiros sociólogos americanos, Small era pastor protestante e estava interessado em temas como reforma social, além de soluções para problemas recorrentes nas grandes cidades como pobreza, violência, entre outros temas relacionados - direta ou indiretamente a fenômenos migratórios. Neste sentido, ele reuniu pessoas interessadas em realizar estudos, na maioria das vezes, na própria cidade de Chicago, uma espécie de laboratório social para estes pesquisadores. Entretanto, cabe acrescentar que, para Hans Joas, é falsa "a ideia de que a Escola de Chicago estava interessada unicamente em promover reformas sociais, ou de que sua natureza específica consistia num reformismo social protestante mais ou menos secularizado" (JOAS In GIDDENS \& TURNER, 1999: p. 143).

${ }^{14}$ Muito embora esta questão não seja aprofundada na tese, cabe ressaltar que o Pragmatismo refuta a perspectiva de que o intelecto e os conceitos humanos podem, só por si, representar adequadamente a realidade. Dessa forma, opõe-se tanto às correntes formalistas como às correntes racionalistas da Filosofia e tem como principais representantes Charles Peirce, William James, John Dewey e Ferdinand Schiller - na condição de pensadores clássicos desta escola. Ademais, importante salientar a existência de distintas nuances com que seus diferentes representantes trataram o termo. 
Abdelmalek Sayad, intelectual argelino, amigo e colega de profissão de Pierre Bourdieu, dedicou-se, ao longo de sua vida, à análise sociocultural dos processos migratórios internacionais, especialmente as múltiplas dimensões da migração africana para a França. Este "analista do inconsciente", como era chamado por Bourdieu, trouxe novas dimensões aos processos de transferências de grupos e culturas de mundos diferentes para o seio da civilização ocidental. (BOURDIEU apud PATARRA, 2006, p.13). Para Sayad (1998, p.15) apesar da imigração ser, em primeiro lugar, um deslocamento de pessoas, “o espaço dos deslocamentos não é apenas um espaço físico, ele é também um espaço qualificado em muitos sentidos, socialmente, economicamente, politicamente, culturalmente (sobretudo através das duas realizações culturais que são a língua e a religião) etc.".

Nesse sentido, mesmo sendo a realidade da imigração algo muito antigo, é relativamente recente o fato de que uma das formas de se perceber, definir ou pensar o imigrante, é tratando-o como um problema social. Ademais, este é um "objeto sobre o qual pesam numerosas representações coletivas". (SAYAD, 1998, p.57)

Dentro dos estudos relacionados ao tema da migração, é possível destacar um importante conceito, especialmente no tocante às análises voltadas para as relações sociais dos migrantes: a etnicidade. Para Cunha (2007, p. 34), este conceito envolve o de identidade. Ainda segundo a linguista, falar sobre identidade é tratar de um termo que tem sido "tradicionalmente usado para descrever ou interpretar o indivíduo, tal como ele se revela e se conhece ou como ele se vê representado em sua própria consciência". Porém, sob uma perspectiva psicológica, a autora afirma que a identidade produz "um sentido de ordem na vida do indivíduo, sob uma perspectiva sociológica ela situa o indivíduo em um grupo. Ambas as perspectivas se completam ao considerarmos que, para saber quem somos, temos que reconhecer a posição em que nos colocamos”.

Segundo o antropólogo Roberto Cardoso de Oliveira (2003, p. 117), “um dos fenômenos mais comuns no mundo moderno talvez seja o contato interétnico, entendendose como tal as relações que têm lugar entre indivíduos e grupos de diferentes procedências 'nacionais', 'raciais' ou 'culturais"”. Neste sentido, o autor traz em Identidade, Etnia $e$ Estrutura Social uma importante reflexão sobre o conceito de friç̧ão interétnica, a qual parte das relações entre indivíduos e grupos distintos - sejam nacionais, transnacionais, 
raciais ou culturais e é um dos fenômenos mais comuns da contemporaneidade. Vale lembrar que a noção de fricção interétnica não apenas pressupunha a existência de conflitos, mas, no âmbito da antropologia, apontava para um esforço em se alcançar a dinâmica e o funcionamento da transmissão e de mudança cultural nas sociedades.

Para o grupo de pensadores do qual Roberto Cardoso fazia parte, essa vertente foi uma resposta ao crescente descontentamento com a noção de aculturação bastante em voga nos estudos em sociedades indígenas, sobretudo por não levar em conta as posições de dominação e de subordinação que adquirem os membros das sociedades em contato, tampouco o conflito entre as técnicas, regras, valores das mesmas sociedades. Ademais, cabe acrescentar que o uso do termo aculturação contribuía para simplificar sobremaneira o estudo de situações complexas e pouco acrescentavam para o avanço teórico deste tema.

Vale lembrar que a questão de choques culturais relacionados a convivências entre culturas diferentes, na maior parte das vezes resultante da presença de migrantes nas cidades foi também muito abordada pelos sociólogos ligados à Escola de Chicago, uma corrente de pensamento norte-americana que também contribuiu sobremaneira para os estudos da Sociologia Urbana.

\subsection{A memória nas Ciências Sociais}

Por ser um tema sobre o qual já se debruçaram - e ainda o fazem, diversos pensadores das mais distintas estirpes ao longo dos últimos séculos, seria impossível esgotar em tão poucas páginas as teorias já elaboradas acerca da memória. Entretanto, cabe aqui destacar, ainda que de forma breve, os principais momentos em que a memória ocupou lugar de destaque em obras de referências para a história do pensamento ocidental.

Para a linguista Maria Jandyra Cavalcanti Cunha, do ponto de vista da Psicologia Cognitiva, "a memória é a faculdade de conservar e lembrar estados de consciência passados e tudo quanto se ache associado aos mesmos. Na Psicologia Analítica, as memórias são reminiscências, lembranças que ocorrem ao espírito como resultado de experiências já vividas" (CUNHA, 2007, p. 18).

Como apontado por Le Goff (2003, p. 419), tal fenômeno, "como propriedade de conservar certas informações, remete-nos em primeiro lugar a um conjunto de funções 
psíquicas, graças às quais o homem pode atualizar impressões ou informações passadas, ou que ele representa como passadas". Entretanto, a preocupação com o tema não se restringe à Psicologia, Psicofisiologia, Neurofisiologia ou à Biologia. Em outras palavras, por ser resultado de sistemas dinâmicos de organização e por existir na medida em que a própria organização os mantém ou os reconstitui, a memória passou a ser associada a fenômenos ligados às esferas das ciências humanas e sociais. De fato, é possível afirmar que os estudos culturais da memória são um campo com que muitas disciplinas têm contribuído, muitas vezes por meio de metodologias e perspectivas específicas. Ao mesmo tempo, a literatura acerca do tema sugere que seu estudo, para que seja bem sucedido, envolve a cooperação de diferentes disciplinas.

Ademais, ao que tudo indica não se trata de um campo apenas multidisciplinar, mas fundamentalmente um projeto interdisciplinar (ERLL, 2008, p.1). De fato, os estudos mais recentes voltados para essa questão parecem apostar na troca interdisciplinar entre História, Sociologia, Neurociência e Psicologia Social, Psicologia Cognitiva e Linguística, para citar algumas. E, quiçá, quanto mais intenso for o diálogo entre as disciplinas mais se descobrirão as múltiplas interseções entre memória e cultura.

Talvez, o ponto de partida mais frequentemente utilizado para adentrar este tema seja a Grécia Antiga - local e época onde a memória ocupou papel de destaque. Tida tanto como sobrenatural, bem como um dom a ser exercitado, a questão empreendeu esforços de filósofos tais como Platão e Aristóteles, que buscavam compreender seu funcionamento $^{15}$. Muito embora não se possa falar em uma homogeneidade quanto às divagações de cada pensador sobre o tema, é possível afirmar que, de modo geral, naquele contexto o "lembrar" e o "inventar" eram ações entendidas como possuidoras de uma profunda relação entre si. Indicativo dessa percepção é o mito de Mnemosine (origem da palavra memória). Contava-se que, de fruto do relacionamento dessa deusa com Zeus, teriam nascido nove filhas, as quais vieram a se tornar conhecidas como Clio (história), Euterpe (música), Talia (comédia), Melpômene (tragédia), Terpsícore (dança), Erato (elegia), Polínia (poesia lírica), Urânia (astronomia) e Calíope (eloquência).

15 A respeito da questão em Platão, ver Teeteto, um diálogo sobre a natureza do conhecimento. E em Aristóteles, ver Da memória e da reminiscência. 
Se na Grécia de Platão e Aristóteles ${ }^{16}$ a memória esteve associada às artes e à história, cabe lembrar que séculos mais tarde, ela ganharia contornos diferentes, especialmente no tocante ao destaque dado a religiões tais como o cristianismo ${ }^{17}$ e o judaísmo. Nessa conjuntura, pode-se dizer que a memória esteve pautada de forma estruturante, pois, com bem destaca Le Goff (2003), era (e ainda é) recorrente entre essas religiões ancorá-la à rememoração de acontecimentos e milagres do passado por meio de celebrações litúrgicas, louvor a santos e mártires, bem como estabelecimento de datas específicas para relembrar milagres e fatos históricos.

Tempos mais tarde, já no século XVII, a reflexão sobre o tema da memória ganharia novo fôlego, uma vez que pensar a "interioridade" era, entre os filósofos, uma forma de acessar a "verdade" e afastar-se das "ilusões". Tais pensadores se alternavam entre a razão e os sentidos para definir a "via privilegiada do conhecimento". Pode-se acrescentar, ainda que, naquele contexto, boa parte das profundas alterações na organização e nas relações sociais se desencadeou em razão ao desenvolvimento dos centros urbanos, bem como ao incremento do comércio como forma de produção de riqueza, à constituição dos Estados Modernos e às Grandes Navegações - atrelada à descoberta de novos povos. Paralelamente a esses eventos, cabe destacar, ainda, a invenção da imprensa, a Reforma (e a contrarreforma) religiosa e, por fim, o surgimento da Física Matemática, que possibilitaram o aparecimento de uma nova visão de mundo, e propiciando, consequentemente, a manifestação de novas perspectivas em relação ao tema da memória - fato que permeou grande parte do exercício intelectual daquela época.

Pode-se situar o nascimento de uma noção moderna a respeito da memória cultural entre o final do século XIX e início do século XX. Antes, porém, cabe acrescentar que o tema contou com aportes significativos, oriundos de pensadores anteriores, tais como Spinoza e Locke no século XVII e Hume e Kant no século XVIII.

16 Para Smolka (2000, p. 176) “Aristóteles distingue a memória propriamente dita, a mneme, faculdade de conservar o passado; da reminiscência, a mamnesi, faculdade de invocar voluntariamente o passado. Sua teoria do conhecimento traz novas contribuições ao estudo da memória".

${ }^{17}$ Exemplo de como o tema era tratado na época Medieval ver Santo Agostinho - O palácio da memória, Confissões, Livro X. 
O século XX começava a despontar no horizonte, quando o filósofo francês Henri Bergson anunciou em "Matéria e Memória, ensaio sobre a relação entre corpo e espírito" a sua ideia de que a memória estaria além da capacidade mecânica cerebral humana (BERGSON, 1999). Para isso, desenvolveu uma abordagem de pensamento que partia do pressuposto da existência de algo mais além do ser biológico. Cabe acrescentar que àquela ocasião, enquanto as ciências naturais eram tidas como referência para uma parte expressiva dos filósofos e acadêmicos, o pensamento bergsoniano se voltava para a questão da intuição.

Em seu método, Bergson distinguiu dois aspectos da memória (FORNAZARI, 2004) - cujas denominações variam de acordo com a leitura de diversos autores: a "memória-lembrança" (também conhecida como lembrança pura ou memória pura), como conservação do passado no presente (onde, portanto, cada novo presente contém uma imagem crescente do passado), e a "memória-contração" (também entendida por memóriahábito ou memória-automática), como acumulação do passado no presente - sendo que os momentos sucessivos da duração se contraem ou se condensam um no outro. Bosi (2009, p. 49) acrescenta que esse tipo de memória se adquire pelo esforço da atenção e pela repetição de gestos ou palavras, além de ser um "processo que se dá pelas exigências da socialização".

Em última instância e de forma resumida, Bergson, ao tomar a definição de memória como um ponto de interseção entre o espírito e a matéria, sugere que é ela que nos distingue e nos afirma como humanos. Por fim, considera ainda que é por meio das imagens que retemos em nossa memória que nos capacitamos para raciocinar, conferir valores, estabelecer julgamentos, acolher, rechaçar e, dessa forma, produzir reflexões e pensamentos.

Contemporâneo e conterrâneo de Bergson, Émile Durkheim formou-se em Filosofia, porém, toda sua obra foi dedicada à Sociologia, da qual é notoriamente conhecido como seu fundador. Muito embora não tenha se dedicado explicitamente sobre a temática da memória (MISZTAL, 2003), o pensamento durkheimniano abordou temas afetos a essa questão, como, por exemplo, a importância das relações societárias e sua força nas ações de cada indivíduo. Sua incursão na discussão sobre o tema deve ser objeto de reflexão, especialmente no tocante à importância dada pelo francês à revitalização da 
herança social de um grupo para reafirmação de seus laços, bem como reforço de suas formas de solidariedade.

É possível ressaltar em comum entre os dois franceses o fato de que tanto Durkheim quanto Bergson, frente a um debate intelectual considerado insuficiente para compreender a questão da memória, buscaram, naquela ocasião, desenvolver uma análise mais sistemática e complexa sobre o assunto, especialmente Henri Bergson.

O mapeamento traçado aqui não poderia deixar de mencionar, ainda, a relevância da obra de Sigmund Freud, que contribuiu sobremaneira no debate acerca do inconsciente - tendo direcionado nova luz à questão da memória ao conceber a memória (rememoração) como sendo a força persistente atuante de uma experiência. Prado (2009) argumenta que o esquema freudiano demonstrava que memória e consciência se excluíam mutuamente e, ainda, a memória seria de tamanha complexidade que se constituiria de diversas maneiras.

Entretanto, uma perspectiva inovadora sobre a questão da memória alcançou enorme impacto ao longo de todo o século XX e influenciou sobremaneira diversas áreas do pensamento humano, tais como a Sociologia, História e Psicologia Social. Em 1925, o sociólogo francês Maurice Halbwachs interessado em como os quadros sociais compõem a memória, elaborou uma espécie de "Sociologia da memória coletiva", consolidando-se como primeiro a escrever explicita e sistematicamente sobre essa questão, e cuja obra é tida como referência para os estudiosos do tema, não importando o campo de trabalho ou país de origem dos respectivos investigadores.

Halbwachs era ligado ao grupo que se constituiu em torno de Émile Durkheim, a chamada "Escola Sociológica Francesa". Tendo ingressado na École Normale Supérieure em 1898, foi aluno de Henri Bergson, o que deixou marcas duradouras em sua obra. De acordo com seu pensamento, toda memória é "coletiva" (incluindo até mesmo aquela aparentemente mais particular, uma vez que ela está atrelada a algum ou mais grupo) e em sua concepção, o indivíduo carrega em si a chamada lembrança, porém, nunca deixa de interagir com outros indivíduos - constituindo os grupos e as instituições.

Deste modo, é exatamente nesse contexto de interação que as pessoas constituem suas recordações. Pode-se inferir que Halbwachs falava, portanto, de um compartilhamento de memória, seja entre os indivíduos que participaram de momentos 
vividos (ou com que estiveram envolvidos) seja pelas ideias e pontos de vista com os quais se identificam, ajudando assim a construir suas percepções e, consequentemente, suas lembranças. Nesse sentido, o rememorar algo estaria em consonância com as memórias dos diferentes grupos com os quais o indivíduo se relaciona, ou seja, está impregnado por outras memórias - mesmo que estas pareçam alheias à história de quem as lembra. ${ }^{18}$

Necessário, aqui, ressaltar a importância que o "outro" exerce nesse conceito de memória coletiva proposto por Halbwachs. Fundamental, também, acrescentar que a memória coletiva tem sido compreendida como peça chave na compreensão de temas como a questão do sentimento de pertencimento a um grupo, identidades, entre outros. Consequentemente, por esse ângulo de leitura seria possível pensar que grande parte das inspirações individuais é, na verdade, influenciada pelos grupos, que determinam tudo aquilo que merece ser lembrado e como deve ser lembrado.

Em suma, Halbwachs teria inventado não somente o termo fundamental "memória coletiva"; como também é possível destacar uma tripla importância de seu legado aos estudos culturais da memória (ERLL, 2008, p. 7): (i) primeiramente, com seu conceito de estruturas sociais da memória, ele articulou a ideia de que as memórias individuais assumem formas específicas e são frequentemente provocadas por contextos socioculturais, ou estruturas históricas, assim já apontando as teorias culturais do esquema e as aproximações contextuais da Psicologia; (ii) em segundo lugar, seu estudo da memória da família ${ }^{19}$ e outras práticas particulares da recordação tiveram grande importância para a história oral; (iii) por fim, com sua pesquisa sobre a memória das comunidades religiosas, o sociólogo francês acentuou aspectos topográficos da memória cultural, assim antecipando a noção de lugar da memória. ${ }^{20}$

${ }^{18}$ Como bem sintetiza Burke (2000): “Os indivíduos se identificam com os acontecimentos públicos de importância para seu grupo. "Lembram" muito o que não viveram diretamente. Um artigo de noticiário, por exemplo, às vezes se torna parte da vida de uma pessoa. Daí, pode-se descrever a memória como uma reconstrução do passado".

19 De fato, segundo Sepúlveda dos Santos, "nos três últimos capítulos de Les Cadres, há uma análise detalhada da construção da memória coletiva a partir da inserção de indivíduos na família, em grupos religiosos e em classes sociais".

${ }^{20}$ Tal conceito seria desenvolvido décadas mais tarde por Pierre Nora. 
Isto não equivale a dizer que a obra de Halbwachs tenha sido lida acriticamente por todos os estudiosos que tomaram tal questão como objeto de estudo. Apenas a título de informação, pode-se citar alguns trabalhos importantes cujos autores elaboraram reflexões críticas quanto ao seu pensamento. De acordo com Guerios (2008, p. 370), o historiador francês Marc Bloch, contemporâneo de Halbwachs, argumentou que o termo "memória coletiva" homogeneizava o grupo e o antropomorfizava ao atribuir-lhe faculdades individuais. Já Bastide teria, segundo Santoa (2013, p. 58), argumentado que, ao definir o termo memória coletiva, Halbwachs reeditou um antigo problema durkheimiano acerca da existência de uma consciência coletiva, alheia aos indivíduos.

É possível mencionar, ainda, Gerárd Namer e Marie-Claire Lavabre como autores que levantaram argumentos sobre a obra de Halbwachs. Em Mémoire et societé, Namer aprofundou algumas das ideias de Halbwachs. No entanto, mesmo concordando com a ideia de que a memória é constituída dentro do grupo, propôs uma relativização desse pressuposto por considerar demasiadamente durkheimiano, ressaltando a dimensão da negociação, de um diálogo interiorizado com o social, constituído a partir de diferentes referências. Já para Lavabre (apud GUERIOS, 2008, p. 373), o conceito proposto por Halbwachs embora emergido na primeira metade do século $\mathrm{XX}$, teria efetivamente se propagado na década de 1970 carregada pelo esforço do pensamento de historiadores interessados na relatividade do conhecimento na história e interpretações acerca dos conflitos. Após ter realizado um importante trabalho na década de 1990 sobre a memória dos militantes comunistas, no entanto, a autora deduziu que "não é possível concluir que existe memória coletiva porque existe na história vivida um evento que pode ser considerado marcante".

Algumas décadas após o relevante trabalho do sociólogo francês ter ocupado lugar de destaque no debate em torno da memória, novos conceitos e formulações surgiram para aprimorar as reflexões sobre o tema. De acordo com Santos (2013), apesar de ter se empenhado em elaborar sua teoria sobre a memória em "termos estritamente sociológicos, sua contribuição é fundamental a qualquer teoria da memória, uma vez que esta necessita ser interdisciplinar e incorporar muitos dos elementos trazidos pela sociologia”.

De fato, é possível constatar que sua importância ultrapassa as ciências sociais ao verificar a produção intelectual conhecida como a terceira geração da Escola dos 
Annales na França, que se tornou referência entre muitos historiadores e teóricos sociais. Pierre Nora e Jacques Le Goff fizeram parte desse grupo e em 1974, editaram juntos o Faire de l'histoire - um manifesto sobre a nova forma de História. De modo bastante sintético, pode-se acrescentar que a chamada Escola dos Annales é compreendida como um movimento que ocorreu na Teoria da História, e que ficou conhecido por esse nome em razão dos principais teóricos terem publicado no periódico acadêmico francês Revue des Annales.

Tal periódico destacou-se por haver incorporado métodos das Ciências Sociais à História. Costuma-se dividir a trajetória da escola em quatro gerações sendo que a primeira foi liderada por Marc Bloch e Lucien Febvre, a segunda teve Fernand Braudel como diretor; a terceira contou com vários pesquisadores ocupando o status de diretores; e por fim, a quarta que teve início em 1989. Dentre os importantes trabalhos publicados no âmbito da terceira geração estão Les Lieux de Mémoire, do historiador Pierre Nora (1984) e Memória, Esquecimento, Silêncio e Memória (1989) e "Identidade Social" (1992), do historiador Michael Pollak, em que ambos também dialogam com o pensamento do sociólogo francês, ainda que apresentem perspectivas distintas das de Halwbachs.

Cabe mencionar, ainda, o trabalho recentemente desenvolvido pelo casal alemão formado por Jan e Aleida Assmann (2008), que defendem a memória como a faculdade que nos permite formar uma consciência acerca da identidade (eu), seja no plano pessoal quanto no coletivo. Pautando-se em Luckmann, que considera o "eu" humano uma identidade diacrônica construída de acúmulos do tempo, Jan e Aleida entendem que tanto esta síntese do tempo quanto da identidade é executada pela memória e, ainda, propõem três níveis para compreensão dos conceitos "tempo", "identidade" e "memória": interno, social e cultural, como mostra esquema a seguir: 


\begin{tabular}{|c|c|c|c|}
\hline Nível & Tempo & Identidade & Memória \\
\hline $\begin{array}{c}\text { Interno } \\
\text { (neuromental) }\end{array}$ & $\begin{array}{c}\text { Interno, tempo } \\
\text { subjetivo }\end{array}$ & Eu interior & Memória individual \\
\hline Social & Tempo social & $\begin{array}{c}\text { Eu social, pessoa } \\
\text { como portador de } \\
\text { papéis sociais }\end{array}$ & $\begin{array}{c}\text { Memória } \\
\text { comunicativa }\end{array}$ \\
\hline Cultural & $\begin{array}{c}\text { Tempo histórico, } \\
\text { mítico, cultural }\end{array}$ & Identidade cultural & Memória cultural \\
\hline
\end{tabular}

Quadro 1 - Esquema desenvolvido por Jan e Aleida Assmann

O termo memória comunicativa foi introduzido no lugar de delinear a diferença entre o conceito de Halbwachs de memória coletiva do conceito de memória cultural de Assmann. A segunda seria uma forma da primeira, no sentido em que ela é compartilhada por um número de pessoas e se expressa a essas pessoas coletivamente, ou seja, como cultura, identidade. Halbwachs, no entanto, o inventor do termo memória coletiva, foi cuidadoso ao manter seu conceito separado do domínio das tradições, transmissões e transferências que os Assmann reúnem no termo memória cultural. Eles preservam a distinção do sociólogo francês ao quebrar seu conceito de memória coletiva em "comunicativa" e "cultural", porém, insistem em incluir a esfera cultural - deixada de lado por Halbwachs em seus estudos sobre o tema.

A memória cultural é expressa por meio de símbolos ligados a determinado acontecimento, ou seja, ritos, festas, canções, monumentos. Há uma inter-relação entre memória comunicativa e cultural, pois uma depende da outra para não ser esquecida: somente com a comunicação e permanência da relevância do acontecimento no grupo ele poderá se tornar símbolo. Com o passar do tempo, se este acontecimento perde sua importância, tanto na comunicação entre os membros do grupo, quanto culturalmente, ele poderá ser esquecido. A forma como a coletividade armazena as lembranças pode se manifestar em atos de lembrança coletiva. Sobre estas manifestações, Erll (2008, p.7) afirma que "as culturas de memória são as manifestações histórica e culturalmente variáveis da memória coletiva". 
Seria possível, aqui, recorrer a outros nomes cujas contribuições quanto ao tema merecem ser lembrados. Entretanto, não se pretende dar conta de uma genealogia do pensamento acerca desse debate e, deste modo, a tese deixará em suspenso, não por serem menos importantes, mas por impossibilidade de esgotar o assunto em tão poucas páginas, as contribuições de Roger Bastide, Gilles Delleuze, bem como de outros pensadores contemporâneos.

Seja qual for a vertente que oriente os estudos sociológicos acerca do tema da migração, não restam dúvidas de que existe uma estreita - porém, pouco explorada, interface entre esta questão e o tema da memória. Vale lembrar que a noção de memória coletiva, inaugurada por Halbwachs e posteriormente recuperada por Michael Pollak, entre outros, pode desempenhar importante papel nas discussões quanto às construções de identidades e, mais ainda, quanto ao sentimento de pertencimento dos imigrantes.

\section{Recorrendo a Pollak:}

Memória é a operação coletiva dos acontecimentos e das interpretações do passado que se quer salvaguardar" e ela está integrada em "tentativas mais ou menos conscientes de definir e de reforçar sentimentos de pertencimento e fronteiras sociais entre coletividades de tamanhos diferentes: partidos, sindicatos, igrejas, aldeias, regiões, clãs, famílias, nações etc. (POLLAK, 1989, p.9)

Dito isso, acredita-se possível pensar na utilização da memória oral (história de vida) enquanto recurso metodológico investigativo que pode contribuir enormemente para os estudos acerca das migrações, tanto como apoio para reconstrução das trajetórias de fenômenos migratórios a partir dos seus agentes como na compreensão de seu processo de adaptação e integração nas sociedades receptoras.

Cabe ainda lembrar que, ao recorrer à história oral como uma forma de estar em contato com os atores sociais e suas lembranças, bem como seus esquecimentos, ressentimentos e sentimentos, há que se considerar a existência, segundo Meihy (1996), de três modalidades da História da História Oral, a saber: (i) a história oral de vida, caracterizada pelos estudos biográficos centrados nos acontecimentos relacionados à vida de um indivíduo, suas experiências, identidade e memória individual; (ii) a história oral 
temática, caracterizada pelos estudos temáticos, centrados em acontecimentos relacionados às experiências, memórias e identidade de grupo/coletividades sociais; e (iii) a tradição oral, caracterizada pelos estudos relacionados ao conhecimento histórico transmitidos oralmente ao longo tempo pelo saber não sistematizado, pelos costumes transmitidos de geração a geração.

Não é intuito da autora tratar esse exercício como trivial. Ao contrário, estudos apontam para uma tarefa complexa, uma vez que ao relembrar suas trajetórias de vida, os imigrantes geralmente desenvolvem discursos explicativos não raro contraditórios, por vezes fragmentados e entrecortados por esquecimentos conscientes e inconscientes, cujo objetivo "parece ser o de dar sentido ao processo imigratório".

Por fim, considera-se importante incorporar um último aspecto na questão da memória e sua relação com a imigração. Trata-se de recuperar a discussão apresentada por Berger e Luckmann (1999) sobre socialização e sua estreita relação com a linguagem. Para os autores, todos os processos de socialização são realizados por meio de uma interação face a face com outras pessoas, sempre envolvendo modificações no microssomo do indivíduo. De início, habilita o indivíduo a ligar-se a determinados outros indivíduos, após isso, torna-o capaz de estabelecer contato com um universo social inteiro.

No caso do imigrante, poder-se-ia supor que o processo de socialização se dá frente ao contato com a sociedade receptora, sua cultura, seus padrões de comportamento, regras e normas, o que, para acontecer, depende do estabelecimento de um tipo de comunicação contínua entre os dois grupos. E para que a comunicação seja possível e eficiente, ambos os grupos devem utilizar a mesma linguagem. Deste modo, tem-se a linguagem como veículo primordial da socialização, pois é com ela que o indivíduo aprende a transmitir e reter certos significados socialmente reconhecidos.

Posto isso, é possível retornar à questão da memória coletiva. Como reflexão feita por Bosi (2009):

Uma memória coletiva se desenvolve a partir de laços de convivência familiares, escolares, profissionais. Ela entretém a memória de seus membros, que acrescenta, unifica, diferencia, corrige e passa a limpo. 
Vivendo no interior de um grupo, sofre as vicissitudes da evolução de seus membros e depende de sua interação. (idem, p.411)

Cabe, por fim, recordar que a tese de Halbwachs inaugurou o entendimento de que nenhuma lembrança pode existir sem a sociedade, tornando impossível separar a memória da linguagem. Para Santos (2013), ao ressaltar o caráter social da memória e explicar que nem mesmo as memórias mais íntimas podem ser pensadas em termos exclusivamente individuais, o sociólogo francês "enfatizou o caráter social do ser humano e antecipou as abordagens culturalistas à história".

Independente de qual seja o enfoque dado a essa temática, conceitos como memória individual, memória coletiva, esquecimento, anamnese, seleção, entre outros, fazem parte do vocabulário de inúmeros estudiosos e interessados no assunto da migração e remetem para uma questão principal: a construção feita no presente a partir de vivências e experiências ocorridas em tempos passados. Este assunto tangenciou a pesquisa por mim conduzida durante todo o processo, haja vista a estreita ligação entre os temas alimentação, migração e cultura, com enfoque nas distintas presenças árabes na cultura brasileira.

\subsection{A alimentação como um componente identitário}

Comer não é um ato solitário ou autônomo do ser humano, ao contrário, é a origem da socialização, pois, nas formas coletivas de se obter a comida, a espécie humana desenvolveu utensílios culturais diversos, talvez até mesmo a própria linguagem. (CARNEIRO, 2005, p.71)

As relações entre comida e sociabilidade é um tema recorrente em pesquisas antropológicas e sociológicas sobre alimentação (ASSUNÇÃO, 2007, p. 526) e, tal como o parentesco, o tema da alimentação sempre esteve presente em toda a trajetória constitutiva do pensar socioantropológico (WOORTMANN, 2009, p. 355).

Audrey Richards, aluna de Malinowski, em Land, labour and diet in Northern Rhodesia (RICHARDS apud MINTZ, 2001, p. 32), lançou luz às funções sociais da 
comida, ilustrando a afirmação de Alfred Kroeber de que a cultura é o modo como as pessoas se relacionam mutuamente estabelecendo relações com seus materiais culturais. De acordo com Levi-Strauss (2009, p. 18), a culinária é um meio através do qual a natureza é transformada em cultura.

A comida pode também despertar certas emoções ligadas à memória. Alguns alimentos podem nos fazer lembrar alguém ou um lugar, através da dimensão afetiva e prazeirosa a ela ligada pela lembrança. Ela aparece então como um elemento desencadeador que permite não somente ativar a lembrança do distante como rememorar amenizando ou acentuando a dor da saudade, que é uma dimensão que pode se supor esteja presente na vivência mais imediata do imigrante, dada a sua situação específica de deslocamento no tempo e espaço.

Roland Barthes (2006, p. 215), em seu clássico Pour une psycho-sociologie de l'alimentation contemporaine, publicado originalmente em 1961, escreveu que as técnicas de preparo dos alimentos, os hábitos adquiridos são parte de um sistema de diferenças em significação e nós nos comunicamos também pela comida. Conforme aprendemos o que comer, como comer, quando comer, nós aprendemos a "nossa" cultura, "nossas" normas e "nossos" valores. Em última instância, esse processo nos ensina "quem nós somos".

Também Massimo Montanari, historiador italiano, e um dos mais importantes pesquisadores da história da alimentação, parte do entendimento de que a comida para os seres humanos é sempre cultura, nunca apenas pura natureza. Segundo o autor de Comida e Cultura (2013), é possível compreender este aspecto cultural ao imaginar analogamente o modelo que propunha Lévi-Strauss sobre a linguagem: existe um léxico - os produtos - e uma sintaxe - a refeição. Esta é constituída, assim como uma gramática complexa, sendo o gosto algo cultural, "resultado de uma realidade coletiva e partilhável, em que as predileções e as excelências destacam-se não de um suposto instinto sensorial da língua, mas de uma complexa construção histórica" .

Montanari (2013) também inspira-se em Lévi-Strauss para tratar a questão da alimentação. Para ele, comida é cultura quando produzida, preparada e quando consumida. O homem pode comer de tudo, porém escolhe sua própria comida, com critérios ligados "tanto às dimensões econômicas e nutricionais do gesto quanto aos valores simbólicos de que a própria comida se reveste". O autor ressalta que consideramos uma comida "boa" ou 
"ruim" a partir daquilo que aprendemos a reconhecer como tal. Segundo ele, não é a língua o órgão responsável por identificar e qualificar os gostos, mas sim o cérebro, um “órgão culturalmente (e, por isso, historicamente) determinado, por meio do qual se aprendem e transmitem critérios de valoração.” (MONTANARI, 2013, p. 95).

Nesse sentido, é importante enfatizar o gosto, não como uma realidade subjetiva e incomunicável, com alguns pensam ser. Mas sim, uma realidade coletiva e comunicada, pois se trata de uma experiência de cultura que nos é transmitida ao longo de nossa socialização, em conjunto com outras variáveis, dando a cada pessoa o sentido de valor dentro de uma sociedade.

A tradição culinária, segundo Reinhardt (2007, p. 156), é o vínculo mais duradouro que o indivíduo tem com seu lugar de origem. Roupas, música e o próprio idioma "materno", por mais que sejam preservados por anos, são elementos que, em algum momento, acabam sendo deixados para trás, de acordo com os autores. No entanto, a comida, de uma maneira ou de outra, se mantém fortemente presente e, mais cedo ou mais tarde, o indivíduo ou seu grupo passam a utilizar as tradições culinárias como um diferencial entre eles e os outros.

Ao considerarmos a alimentação um dos elementos que formam e que expressam nossa identidade cultural, social, regional ou étnica (DAMATTA, 1986), estamos compreendendo a questão da culinária como uma forma com que os imigrantes encontraram para preservarem traços de sua identidade e repassá-las a seus descendentes. Em outras palavras, a adoção de hábitos culinários provindos de imigrantes expressa um repertório de experiências e de memórias que vão se transformando em função do contato entre a sociedade receptora e pessoas oriundas de outras culturas estrangeiras.

Para sobreviver precisamos comer. No entanto, o alimento é mais do que uma fonte de energia e nutrientes essenciais para a saúde humana e o bem-estar. O que comemos, como comemos e quando comemos refletem a complexidade de grandes arranjos culturais em torno da alimentação. A comida desempenha um papel fundamental na socialização humana, no desenvolvimento de uma consciência do corpo e de si mesmo, na aquisição da linguagem e desenvolvimento da personalidade. Como Barthes (2013) argumenta: 
¿Qué es la comida? No es sólo una colección de productos, merecedores de estudios estadísticos o dietéticos. Es también y al mismo tiempo un sistema de comunicación, un cuerpo de imágenes, un protocolo de usos, de situaciones y de conductas. (BARTHES, 2013, p. 215)

A identidade de um povo tem como base, principalmente, sua língua e sua cultura alimentar. Um conjunto de práticas alimentares determinadas ao longo do tempo por uma sociedade passa a identificá-la e muitas vezes, quando enraíza, se torna patrimônio cultural (SONATI et al., 2009, p. 137). Enquanto o alimento diz respeito a todos os seres humanos, por ser universal e geral, a comida define um domínio de opções, manifesta especificidades, estabelece identidades.

Nas palavras de Roberto DaMatta (DAMATTA apud AMON \& MENASCHE, 2008, p. 13), comida é o alimento transformado pela cultura. Neste sentido, a culinária é um forte registro da cultura de um povo. Ela indica costumes e é uma forma dos imigrantes não perderem boa parte de sua identidade, uma vez que por meio da culinária, estão sempre reforçando hábitos e costumes.

A cultura alimentar nas Américas está fortemente relacionada às populações que para cá se deslocaram trazendo hábitos, necessidades, variedades de alimentos, temperos, mudança nas preferências, receitas, crenças e tabus. A cozinha brasileira é o resultado das influências portuguesa, negra e indígena, mas devemos considerar que o país possui uma dimensão continental não somente do aspecto geográfico, mas principalmente na sua diversidade cultural implantada pelos imigrantes que aqui se instalaram (italianos, alemães, japoneses, espanhóis, árabes, suíços e outros). (SONATI, et al. 2009, p. 142)

O modo de alimentar sempre ultrapassa o ato de comer em si e se articula com outras dimensões sociais e com a identidade (CANESQUI, 2005, p. 36). Em 1996, a antropóloga Maria Eunice Maciel identificou o forte valor simbólico de certos pratos típicos, e como se relacionavam a identidades regionais, como, por exemplo, o churrasco gaúcho, cercado do ritual da comensalidade. Para ela, "Os hábitos alimentares não existem isoladamente e nem é possível entender a alimentação de um povo sem ver o todo, a 
circunstância de existência deste, como se revela o seu ethos particular, como é construída sua identidade". 21

Outras identidades se expressam em vários pratos típicos regionais, como a comida mineira, com o tutu de feijão, a leitoa pururuca, o torresmo, entre outros; o pato ao tucupi, dos paraenses; ou ainda o arroz com pequi dos goianos, diversificando-se os regionalismos alimentares no Brasil, sem que esses pratos, tão bem definidos geograficamente, façam parte da realidade cotidiana de seus habitantes, sendo alguns deles famosos em todo o país, como lembrou aquela autora. (CANESQUI, 2005, p. 39).

Ainda segundo Lima (2005):

Estudar a cultura na mesa brasileira é ir bem mais além das tradições e influências dos nativos indígenas, das iguarias africanas e das suculências portuguesas. Pois, a cozinha é um reativo de rara sensibilidade para avaliar a cultura de uma população, é um conjunto de signos e símbolos que ao serem interpretados dão compreensão a história civilizatória de um povo. (LIMA, 2005, p. 14)

Embora o enfoque dado à alimentação por Gilberto Freyre e Câmara Cascudo tenha sido no sentido de apontar traços de identidade regional e nacional, e não houvesse uma sistematização própria para se tratar desse assunto, o tema se fez presente em grande parte da obra dos dois estudiosos, que também se debruçaram, como será mostrado adiante, sobre a questão da herança ibérica em nossa cultura e como, indiretamente, os mouros para fazer uso de suas palavras - se fizeram presentes durante nossa própria formação enquanto nação.

${ }^{21} \mathrm{O}$ significado do ato alimentar. Disponível em: http://www.ihuonline.unisinos.br/index.php?option=com_content $\&$ view=article $\&$ id $=3640 \&$ secao=350.

Acesso em: maio 2014. 
De acordo com Dutra (2005, p. 32), tanto Freyre quanto Cascudo se empenharam em tratar o tema da alimentação como fator constitutivo da identidade nacional. Cascudo, mais incisivamente, com obras dedicadas exclusicamente ao tema, como A cozinha africana no Brasil, História da Alimentação no Brasil e Antologia da Alimentação no Brasil (CAVIGNAC, \& OLIVEIRA, 2010, p. 64).

Para Dutra (2005):

Ressalvando-se as diferenças entre os dois autores (inclusive por trajetórias distintas), podemos considerá-los portadores, dentre outros, do projeto da inteligentsia brasileira, na primeira metade do século passado, de construir a identidade nacional valorizando exatamente o que era considerado o grande empecilho para nossa construção como nação e para o "progresso" da sociedade brasileira: a mistura, a mestiçagem que nos distanciava do padrão europeu de tradição, cujo prejuízo estaria relacionado a fortes componentes raciais. (DUTRA, 2005, p. 32)

Por sua vez, Asfora (2005) afirma que:

A culinária sempre teve um papel muito importante na formação cultural dos povos. [...] Entretando, nem sempre houve esse reconhecimento. Coube ao Dr. Gilberto Freyre, com sua forte veia regionalista e progressista, chamar a atençaõ, em 1926, no seu "Manifesto Regionalista", para a importância em admitir a culinária na formação da nacionalidade brasileira, o que até então, ninguém tinha tido coragem de fazer. (ASFORA, 2005, p. 18)

Gonçalves (2004, p. 3), destrincha com maestria as categorias encontradas na obra de Cascudo, que, em contraponto à perspectiva intelectual expressada por Josué de Castro em A geografia da fome (1946), escrevia sobre comidas e bebidas populaes do ponto de vista do paladar. Neste sentido, Cascudo trata as diferenças dos termos "nutrição", "alimentação", "comida", "refeição", "fome” e "paladar", estruturando seus escritos etnográficos e sua interpretação da cultura popular brasileira. 
O tópico "alimentação" se faz amplamente presente nos escritos etnográficos de Cascudo. Comida e bebida aparecem em muitos de seus estudos sobre narrativas, provérbios, festas populares, religiões etc. Mas ele também escreveu trabalhos específicos sobre o tema. Um deles é a História da Alimentação no Brasil, obra em dois volumes publicada pela primeira vez em 1967 (Cascudo, 1983 [1963]). Em 1968, publicou um livro breve, porém, útil, sobre a história e os significados da cachaça, Prelúdio à cachaça (Cascudo, 1986 [1968]). Em 1977, publicou a Antologia da alimentação no Brasil, em que reuniu um conjunto de textos literários, documentos históricos, artigos de jornais antigos e textos de estudiosos do folclore sobre comidase bebidas. Ao longo de sua carreira, publicou numerosos artigos sobre as diversas formas de classificação, preparo e consumo de comidas e bebidas no Brasil. (GONÇALVES, 2004, p. 3)

Para Cascudo, o fato de escolhermos nossos alimentos diários a partir de um "paladar" que é determinado por padrões, regras e proibições culturais, revela o complexo cultural a que estamos imersos. Segundo ele, "nosso menu está sujeito a fronteiras intransponíveis, riscadas pelo costume de minênios". (CASCUDO apud GONÇALVES, 2004, p. 4)

Buscando verificar de que forma as tradições alimentares se configuram como um ponto de condensação capaz de evidenciar algum tipo de reconhecimento de uma identidade árabe em nosso cotidiano, esta pesquisa foi conduzida por meio de diferentes técnicas de coleta de dados e levantamento de informações que permitiram, entre outras constatações, verificar a forte relação entre identidade e tradições alimentares árabes, corroborando o que Gilberto Freyre e Câmara Cascudo apontavam em parte de sua obra e que, consequentemente, compreendiam como sendo elementos constitutivos de nossa matriz cultural.

\subsection{Representações Sociais e a Construção de Imaginários}

Muito embora a Teoria das Representações Sociais esteja hoje intrinsecamente associada à obra de Serge Moscovici - representante da escola psicossocial construtivista 
francesa (ARAUJO, 2008), é possível nos remetermos a outro francês, o sociólogo Émile Durkheim como um dos precursores da reflexão acerca das representações coletivas, o qual contribuiu significativamente para o desenrolar dessa teoria. Cabe ressaltar que as chamadas Representações Sociais não pertencem a um único campo de conhecimento e que suas raízes perpassam pela Sociologia, Antropologia, Psicanálise e se desenvolvem na psicologia social, tendo sido posteriormente aprofundada por outros autores, entre eles, Denise Jodelet.

É possível mencionar a década de 1960 como o período de grande interesse pelo estudo dos fenômenos do domínio simbólico. Tais investigações recorreram às noções de consciência, imaginário, representação e memória social, na busca por explicações teóricas, as quais se aprofundaram cerca de 20 anos depois e passaram, a partir de então, a servir como ferramenta para outros campos, entre eles a saúde, a educação, a didática e o meio ambiente, apenas para citar alguns exemplos.

Não é trivial definir o conceito de Representações Sociais, haja vista sua composição polimorfa. Soma-se a isso o fato de que a teoria proposta por Moscovici não se caracteriza como a única possibilidade de análise para esta temática, em que pese ter sido, até o momento, o aporte teórico escolhido para conduzir esta pesquisa.

A fim de dar partida ao estudo, as Representações Sociais foram tomadas como um conjunto de conceitos, proposições e explicações originados na vida cotidiana no desenrolar das comunicações interpessoais. Elas são formadas por meio de influências recíprocas, através de negociações implícitas no curso das conversações, onde as pessoas se orientam para modelos simbólicos, imagens e valores específicos que são coletivamente compartilhados (MOSCOVICI, 2003). Ainda nesse processo, as pessoas adquirem um repertório comum de interpretações e explicações, regras e procedimentos que podem ser aplicadas à vida cotidiana, do mesmo modo que as expressões linguísticas são acessíveis a todos.

No entanto, este conceito pode adquirir outras profundidades. Denise Jodelet (2002), ao avançar na teoria proposta por Moscovici, defendeu que as Representações sociais fossem definidas como sendo uma forma de conhecimento socialmente elaborado e compartilhado com um objetivo prático e que contribui para a construção de uma realidade 
comum a um conjunto social. Elas são equivalentes aos mitos e às crenças das sociedades, ou seja, pertencem ao conjunto das práticas simbólicas.

É importante considerá-las como uma maneira específica de compreender e comunicar o modo pelo qual interpretamos o mundo. As representações sociais ocupam uma posição, em algum ponto, entre conceitos que têm como objetivo abstrair o sentido do mundo e introduzir nele ordem e percepções que reproduzam o mundo de forma significativa. (MOSCOVICI, 2003)

As representações sociais funcionam como um sistema de referências simbólicas sobre a realidade, atuando nas relações estabelecidas pelos indivíduos no meio em que estão inseridos, orientando, assim, seus comportamentos e práticas. Cabe acrescentar que não existem representações sociais homogêneas em uma sociedade, pois seus membros dependem tanto do conhecimento do senso comum como do contexto sociocultural em que os indivíduos estão inseridos.

Ainda como contribuição do psicólogo social Serge Moscovici, as maiores preocupações teóricas observadas, não focam apenas em como o conhecimento nas sociedades é produzido, mas principalmente qual o seu impacto nas práticas sociais e viceversa. Seus interesses, segundo ele próprio, pautam-se no "poder das ideias" de senso comum, isto é, no "estudo de como, e por que as pessoas partilham o conhecimento e desse modo constituem sua realidade comum, de como eles transformam ideias em práticas". (OLIVEIRA, 2004)

Sobre a relação entre representações sociais e o imaginário social, não existe necessariamente uma relação direta. Elas são associadas ao imaginário quando a ênfase recai sobre o caráter simbólico da atividade representativa de sujeitos que partilham uma mesma condição ou experiência social: eles exprimem em suas representações o sentido que dão a sua experiência no mundo social, servindo-se dos sistemas de códigos e interpretações fornecidos pela sociedade e projetando valores e aspirações sociais (JODELET, 1990).

Em suma, e de modo bem geral, a vertente das representações sociais se mostrou relevante no sentido em que pensar a complexidade do uso da palavra "árabe" e as principais interpretações acerca do substantivo, é colocar em perspectiva como se formam 
e como funcionam os sistemas de referência que utilizamos para classificar pessoas e grupos e para interpretar os acontecimentos da realidade cotidiana relacionados ao objeto.

A primeira etapa do levantamento de dados desta pesquisa permitiu essa verificação. Ao convidar as pessoas para participarem de um estudo exploratório que buscava conhecer que representações sociais poderíamos elencar ao analisar fotografias enviadas por voluntários de toda parte do Brasil que representassem, na opinião de cada um, exemplos das diferentes presenças árabes em nossa cultura, tive a oportunidade de ver o quão diferenciado era a compreensão de cada participante sobre quem eram os árabes, e como são vistos em nossa sociedade.

Neste capítulo, foram apresentados alguns conceitos que tiveram o importante papel de nortear a pesquisa ao longo de sua concepção e realização. A partir desse esforço foi possível identificar com melhor clareza os principais resultados alcançados por meio das entrevistas, visitas de campo e observações participantes feitas neste trabalho e que serão apresentados um pouco mais adiante. Espera-se, destarte, que a relação entre memória, alimentação e identidade seja mais facilmente compreendida pelo leitor, especialmente no tocante à sua importância para o reconhecimento de aspectos culturais oriundos de uma cultura estrangeira em nossa sociedade, mais especificamente a árabe.

Neste sentido, o capítulo seguinte cumpre a tarefa de problematizar a polissemia da palavra "árabe", e indica ao leitor um conjunto de variáveis que podem alterar substancialmente a compreensão e, consequentemente, o recorte do objeto. Cabe aqui ressaltar, entretanto, que o uso da palavra "árabe" não se esgota a partir de uma única definição, seja sobre quais aspectos que estamos tratando, seja sobre quem exatamente estamos falando.

Por esta razão, o capítulo seguinte apresenta uma breve reflexão sobre o quão abrangente pode ser o uso deste substantivo, focando em um conjunto de elementos que merecem ser discutidos, mas também colocados em perspectiva, para que se tenha uma noção da dificuldade encontrada no início da pesquisa para recorte do objeto tratado. 


\title{
CAPÍTULO 2 \\ A CONSTRUÇÃO DE IMAGINÁRIOS E A POLISSEMIA DA PALAVRA “ÁRABE”
}

\begin{abstract}
A história dos povos árabes, portanto, tem pouco a ver com o resultado cristalizado no mapa contemporâneo. Por outro lado, seria um equívoco imaginar um passado homogêneo e glorioso, um suposto tempo mítico, quando a identidade árabe era plena entre todos os povos que, de alguma forma, participam dessa história. E aqui apenas começa o problema: o que significa ser árabe? Houve algum momento da história em que a identidade árabe foi plenamente realizada sobre um território que abrange “do Golfo ao Atlântico?” (ARBEX, 2009, p. 10)
\end{abstract}

O propósito deste capítulo é oferecer ao leitor um panorama geral sobre o quão complexo pode ser tratar de um tema cuja definição é pouco precisa e, consequentemente, possibilita o surgimento de um conjunto enorme de interpretações e representações sociais acerca do objeto tratado nesta tese.

Durante a realização desta pesquisa, procurou-se refletir sobre diferentes presenças árabes no Brasil, sejam elas passíveis de identificação pela via histórica ou cultural. Ao adotar essa relativa fluidez em torno de seu objeto, foi dado espaço para que distintas representações sociais acerca dos árabes em nossa cultura se fizessem notadas. Concomitantemente, foi possível identificar as variantes que marcam e contornam a construção de identidades árabes em nossa cultura, e que serão analisados com atenção nos dois últimos capítulos.

\subsection{Problematização do conceito: quem são os “árabes" e o esforço para delimitação de um campo de estudo}

Dada à complexidade da discussão sobre o que significa ser árabe hoje em dia (e as implicações sociais, políticas, econômicas culturais, linguísticas dessa discussão, apenas para citar alguns exemplos de fatores que interferem nesse assunto), seria uma tarefa quase impossível conduzir o leitor ao capítulo de descrição dos resultados da 
pesquisa sem antes oferecer uma reflexão a respeito de qual cultura se está falando. Portanto, considerou-se condição primordial apresentar um pouco das principais reflexões em torno da palavra, bem como as recorrentes confusões provocadas pela difusão de estereótipos e desinformações que frequentemente acompanham os árabes.

Pode-se dizer que a história dos atuais países árabes enquanto nações independentes, não é antiga e parte da confusão existente atualmente em relação à compreensão sobre quem são os árabes está relacionada à sua história e à forma como a religião islâmica esteve associada a um período de expansão de um império que posteriormente viria a sofrer uma intensa retração.

Em termos geográficos, a Península Arábica ${ }^{22}$ foi habitada por vários séculos por tribos nômades, até que no século VI iniciou-se um processo de unificação. Naquele momento, um líder com uma impressionante capacidade agregadora e estratégica inspirou os habitantes daquela região a ponto de consolidar o Islã como uma das maiores religiões e impérios que se tem notícia. Maomé nasceu no ano 570 e faleceu e 632. É considerado, pelos muçulmanos, o último profeta de uma linhagem que contém Abraão, Ismael, Isaac, Jacó, Davi e Jesus. Foi o responsável por um processo de unificação e expansão que vai do século VII partindo do que se conhece atualmente como Oriente Médio, alcançando a Pérsia (hoje chamada de Irã), o norte da África e parte de Portugal e Espanha.

\footnotetext{
${ }^{22}$ A Arábia é uma península da Ásia Ocidental, próxima da África. Limita-se a noroeste com a Palestina, ao sul com o oceano Índico, a leste com o golfo Pérsico e a oeste com o mar Vermelho.
} 


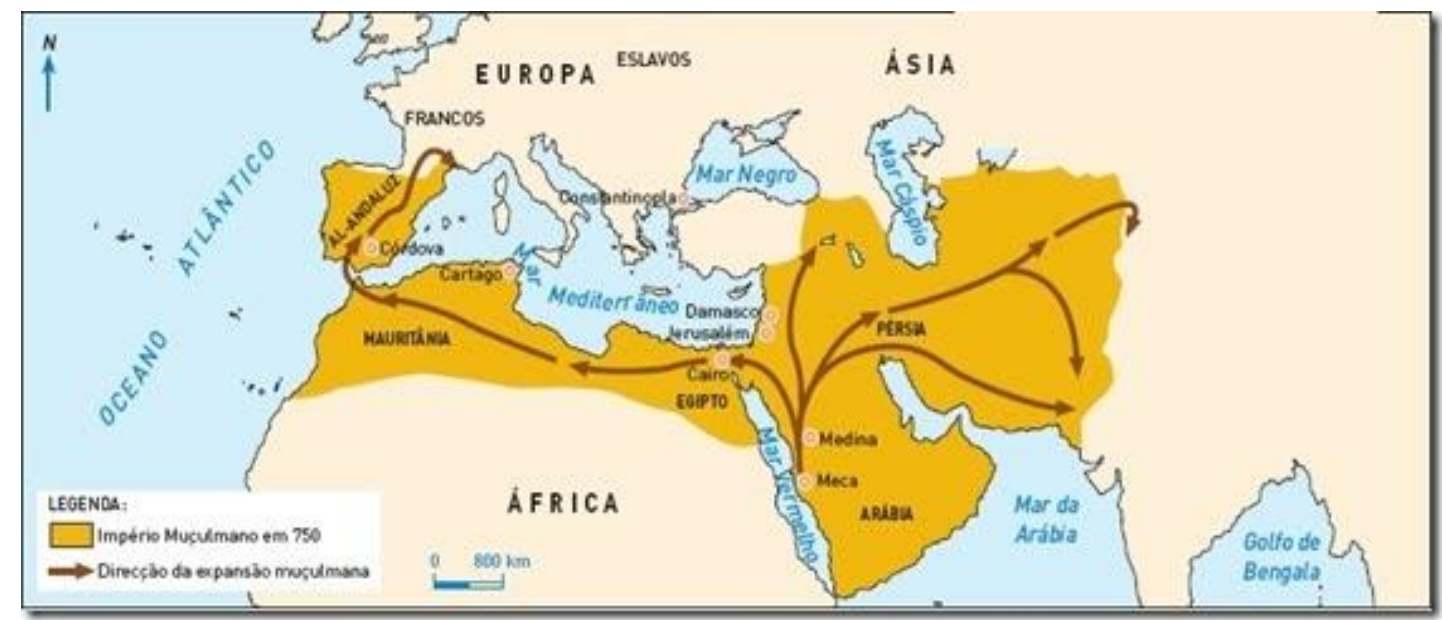

Figura 1 - A expansão do Islã até o ano 750.

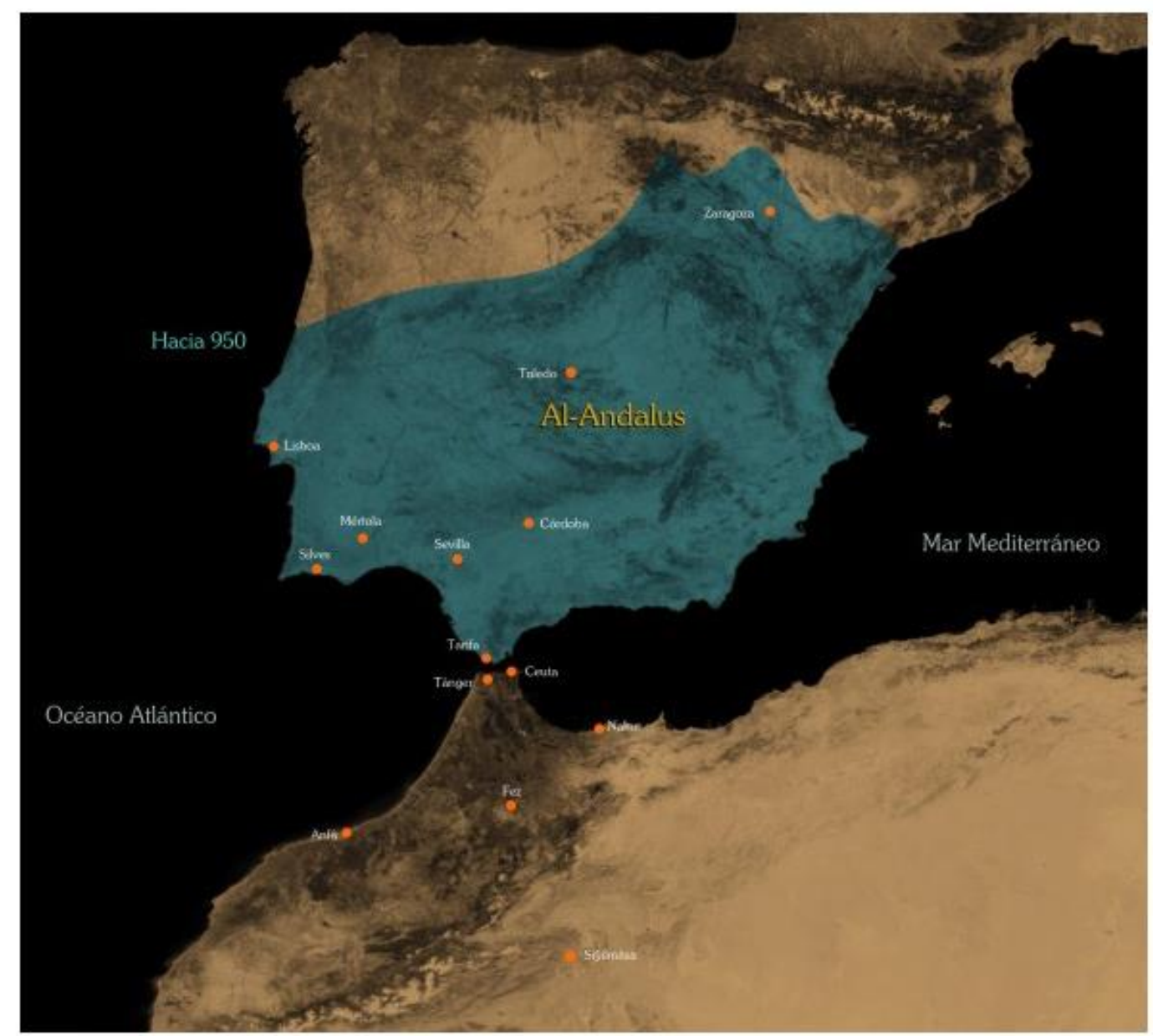

Figura 2 - Mapa do al-Andalus, na Península Ibérica, no ano 950, durante o Califado Omíada (711-1031) ${ }^{24}$

\footnotetext{
${ }^{23}$ Fonte: Mestres da História. http://mestresdahistoria.blogspot.com.br/ Acesso em agosto de 2014.
} 
No entanto, a impressionante expansão religiosa e cultural iniciada por Maomé conhece seu declínio a partir do século XIII, porém, quando suas fronteiras começaram a retrair. No século XV os golpes foram ainda mais fortes, culminando com a queda de Granada e o ataque pelos turcos otomanos em terras muçulmanas.

Importante mencionar que o Islã, religião nascida na Península Arábica, que unificou tribos, extrapolou suas fronteiras e se expandiu de forma rápida levando o idioma árabe e uma cultura que ia sendo forjada ao longo desse processo para todos os locais por onde se instalou, teve um papel central na difusão do que hoje poderia ser chamado de uma "cultura árabo-islâmica". Cabe mencionar que por onde o Império Islâmico passou, a conversão religiosa não era imposta, embora houvesse incentivos para que as pessoas adotassem a nova fé. Destaca-se, porém, que a cultura árabe naquele momento tornou-se fortemente associada à religião, pois mecanismos de expansão deste projeto de nação intensificaram este amalgama que envolvia o idioma árabe, a busca pelo conhecimento, pelo refinamento da música, da arquitetura e da ciência. Cidades como Damasco, e posteriormente Bagdá, foram centros culturais importantes e, embora o processo de expansão religiosa não tenha sido livre de conflitos, batalhas e disputas, estes polos irradiaram conhecimento e eram tomados como referências aonde quer que o Islã tivesse chegado.

Diante desse contexto, é possível compreender porque, embora a cultura arábica não seja homogênea e possua suas nuances internas, que variam de região para região, passou a ser fortemente associada à religião islâmica. No entanto, cabe lembrar que outros povos assumiram o controle do império islâmico em séculos seguintes, tendo

${ }^{24}$ Califado (do árabe خلاف $ة$ خأ transl. khilāfa) é a forma de governo que representa a unidade e liderança política do mundo islâmico. A posição de seu chefe de Estado, o califa, baseia-se na noção de um sucessor à autoridade política do profeta islâmico Maomé. Desde o advento do islã até 1924, diversas dinastias alternaram-se sucessivamente no califado, incluindo os omíadas, que foram expulsos de Damasco para Córdoba, no al-Ândalus (na Península Ibérica), os abássidas, que governaram a partir de Bagdá, os fatímidas, que governaram a partir de Cairo, no Egito, e, finalmente, os otomanos. Fonte da imagem: El Legado Andalusí Fundación Pública Andaluza www.legadoandalusi.es/ Acesso em agosto de 2014. 
contribuído, não apenas para o enriquecimento cultural da religião sob a perspectiva das artes, ciências, arquitetura, filosofia ou estratégias de guerra, mas também impregnaram a religião com elementos culturais bastante distintos daqueles originalmente relacionados à região onde o islã nasceu, qual seja, a Península Arábica.

Provavelmente, um dos elementos que mais chamaram a atenção ao longo da pesquisa realizada para elaboração deste documento foi a vastidão de compreensões que ocupam as mentes das pessoas quando se fala sobre os árabes. Primeiramente, é crucial mencionar que não raro se observa uma tendência das pessoas a tratarem os países árabes como se fossem todos iguais. No capítulo referente à apresentação dos resultados da pesquisa, serão expostas as representações mais recorrentes observadas durante o período que compreendeu o levantamento de dados primários. Ainda que não seja o intuito desta tese tecer análises aprofundadas acerca das representações sociais sobre os árabes e consequentes confusões sobre o assunto, as quais foram observadas durante a pesquisa, considera-se oportuno registrar uma pequena reflexão em torno desse assunto antes de seguirmos adiante.

\subsection{Quem são os árabes}

A palavra "árabe", embora um substantivo simples, carrega um conjunto de significados e representações sociais. Ela pode ser usada com conotações distintas nos diversos campos de conhecimento existentes, tais como o geográfico, o linguístico e o histórico. E ainda, com frequência é associada a assuntos religiosos e políticos, sendo comum despertar posicionamentos carregados de preconceitos e desinformação. $\mathrm{O}$ conceito também foi objeto de análise por parte de muitos intelectuais, alguns dos quais serão citados adiante, preocupados em definir o que isso representa e como interfere identitariamente sobre as pessoas que se autodenominam árabes.

No entanto, por estarmos falando de um tema inesgotável, procurei estabelecer aqui um conjunto de referenciais teóricos que foram acessados durante o estudo, a partir dos seguintes critérios:

(i) o acesso às publicações;

(ii) o tempo hábil para aquisição do material consultado; 
(iii) indicações mencionadas na bibliografia utilizada na elaboração do projeto e;

(iv) referenciais teóricos consagrados na Sociologia.

Antes de dar início à apresentação de importantes apropriações para o uso da palavra árabe nos dias atuais, há de se lembrar que o assunto foi e tem sido amplamente tratado em outras áreas do pensamento social, com destaque para a Ciência Política, as Relações Internacionais e a História.

Esta seção tratará ainda, porém, de forma breve, a noção de nacionalismo árabe, conceito que vem sendo amplamente discutido e rebatido especialmente nas relações internacionais e sua compreensão sobre os principais desafios que envolvem o mundo árabe nos dias de hoje. Um tema polêmico, cuja ideologia foi, e ainda é, questionada do ponto de vista da sua origem, seus ideais e impactos, durante anos tendo sido difundido tanto no meio político, quanto acadêmico e midiático, e que gerou profundos impactos sobre o mundo árabe.

\subsubsection{A dificuldade do recorte}

Em 1982, a historiadora brasileira Maria Yedda Linhares, ao publicar o livro $O$ Oriente Médio e o mundo árabe chamou atenção para o fato de que "Oriente Médio" e "Mundo Árabe" são expressões cujos conteúdos tendem a se confundir na mente do leitor comum da "crônica internacional". Segundo ela, o primeiro termo passou a ser bastante utilizado a partir dos anos 1940 para designar uma área do globo terrestre "de cerca de uma dezena de milhões de quilômetros quadrados e uma população em crescimento explosivo cujas cifras ultrapassam a marca dos 200 milhões de habitantes". (LINHARES, 2004, p. 10) 


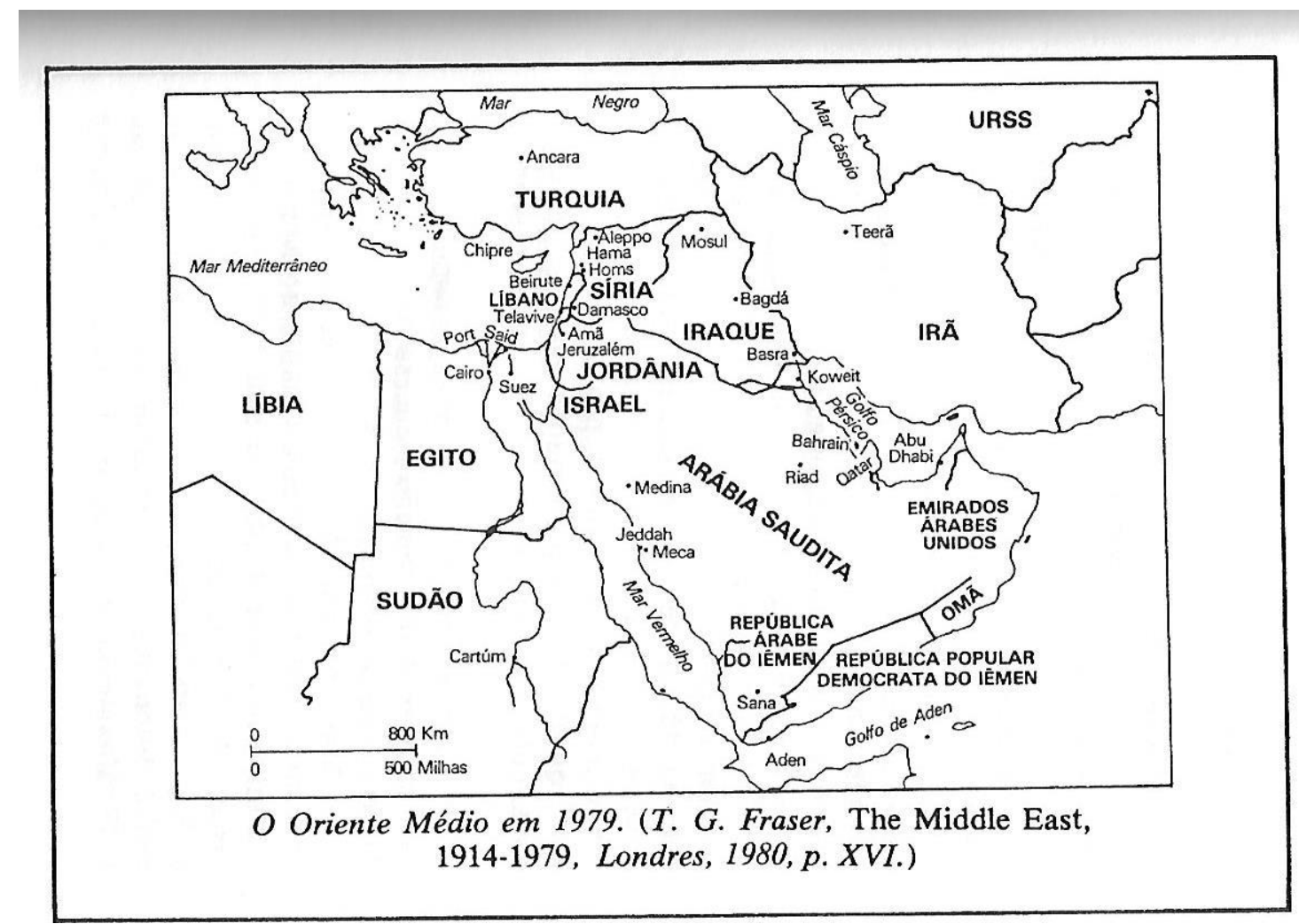

Figura 3 - O Oriente Médio em $1979^{25}$

Já a palavra árabe, pela sua própria etimologia, significa "nômade que vive sob a sua tenda no deserto" (embora essa definição não seja aceita por todos os estudiosos do tema) e, por essa razão, o termo, durante séculos, se referiu mais a um "gênero de vida e organização social do que a uma língua e, menos ainda, a uma raça”. Entretanto, de acordo com Linhares, faz-se importante reforçar sempre o fato de que os povos aos quais chamamos de árabes representam um conjunto heterogêneo do ponto de vista étnico:

A própria língua árabe, que se difundiu, arabizou populações e gerou mais arabizados do que árabes propriamente ditos, povos que passaram a se identificar pela língua, pela religião e pelos hábitos sociais. Assim como os povos, a língua sofreu transformações e apresenta hoje variações acentuadas segundo o país e o grau maior ou menor de assimilação com populações e culturas preenxistentes. (idem, p. 18)

${ }^{25}$ LINHARES, 2004, p. 51. 
Não raro, existe atualmente uma tendência a se referir ao termo árabe ao se falar sobre uma região particular do mundo: autointitulam-se árabes quase todas as pessoas na localização que se estende desde a Costa Atlântica do Norte da África até o Golfo Pérsico. Cabe menção, neste caso, a famosa citação de Sati'Al-Husri: "al-Umma al'Arabiya min al-Muhit al-Atlasi ila al Khalij al-arabi" ou, em português, "eu professo de todo meu coração a religião do arabismo" (DAWISHA, 2003, p. 185), frase que pode ser tomada como ilustração sobre como a origem do nacionalismo árabe, ideologia que busca valorizar e enaltecer as glórias da civilização, a língua e a literatura "árabes", conclamando uma união política desde o Oceano Atlântico ao Mar Arábico, em contraposição ao domínio "ocidental” naquela região.

Esta corrente ideológica se desenvolveu no inico do século XX por oposição ao otomanismo. O movimento nacionalista turco, por meio do movimento dos Jovens Turcos, influenciou o nacionalismo árabe: propunha-se transpor o otomanismo fundado sobre a unidade muçulmana para o arabismo fundado sobre a cultura árabe contra a cultura e a nação turca. (CARRÉ, 2013, p. 25)

Tal ideologia está pautada na compreensão da existência de um idioma comum (árabe) e do compartilhamento de um senso de identidade geográfica, histórica e cultural ${ }^{26}$. Ainda que essa formulação pareça um tanto quanto reduzida, é importante salientar que essa palavra carrega um conjunto de significados e representações sociais que muitas vezes podem adquirir contornos bastante complexos.

Embora se imagine que as pessoas compreendam que uma família árabe em Beirute - capital do Líbano - possua hábitos distintos de uma família em Túnis - capital da Tunísia -, por exemplo, na maioria das vezes é recorrente encontrar mais generalizações e confusões em torno da palavra "árabe" do que esclarecimentos. Além de um componente político responsável por este conjunto de incompreensões acerca do tema, confusões ocorrem também motivadas por questões religiosas.

${ }^{26}$ Guide to Arab Culture: Health Care Delivery to the Arab American Community. Documento publicado em 1999 pelo Arab Community Center for Economic and Social Services, nos Estados Unidos da América. Disponível em: http://www.accesscommunity.org/site/DocServer/health_and_research_cente_21.pdf. Acesso em: 24 jul. 2013. 
Em tempo, com alguma frequência observa-se, por exemplo, que em várias esferas da sociedade existe uma tendência a se considerar os muçulmanos como se fosse um grande grupo homogêneo - em outras palavras - todos iguais. E, ainda, repetidamente deparamo-nos com o "discurso" de que ser árabe é ser muçulmano. Não obstante, muita gente se esquece ou sequer sabe que a religião islâmica é praticada por quase $1 / 4$ da população mundial $^{27}$, está presente em mais de 50 países, e que existe no comportamento desse 1,3 bilhão de pessoas tanta diferença cultural que seria no mínimo absurdo tratá-las e tomá-las como iguais.

Do ponto de vista identitário, diferentes pessoas, muitas vezes algumas delas sem qualquer relação entre si, podem se sentir árabes ou sentir que pertencem a uma cultura dita "árabe" ${ }^{28}$. Uma das discussões mais recorrentes em torno desse sentimento diz respeito ao processo de arabização vivido por diversos países por onde o império islâmico percorreu na chamada etapa áurea da religião.

Nesse sentido, o imaginário criado a respeito dessa palavra desperta grande interesse sociológico. Ao longo da pesquisa realizada, uma situação ocorrida corriqueiramente foi encontrar e conversar com pessoas que pouco sabiam sobre o que caracterizaria o chamado "mundo árabe", embora se mostrassem sempre à vontade para falar sobre o assunto, até mesmo tecendo afirmações díspares ou equivocadas.

No início do século VII, surgiu às margens dos grandes impérios, o Bizantino e o Sassânida, um movimento religioso que dominou a metade ocidental do mundo. Em Meca, cidade da Arábia Ocidental, Maomé começou a convocar homens e mulheres à reforma e à submissão à vontade de Deus, expressa no que ele e seus seguidores aceitavam como

${ }^{27}$ O percentual de muçulmanos no mundo está previsto para atingir um quarto da população mundial até 2020. (ALVES, 2010) Disponível em: http://www.ufjf.br/ladem/2010/04/13/transicao-demografica-nospaises-islamicos-artigo-de-jose-eustaquio-diniz-alves/. Acesso em: 24 jul. 2013.

${ }^{28}$ Ao longo da pesquisa realizada entre 2011 e 2014, e que será apresentada no capítulo 4, essa reflexão foi recorrente, tanto nas entrevistas feitas com árabes e descendentes, quanto nas discussões observadas na página Presença Árabe no Brasil, criada especificamente como ambiente virtual que possibilitasse maior contato com a comunidade árabe no Brasil. 
mensagens divinas a ele reveladas e mais tarde incorporadas num livro, o Corão. Em nome da nova religião — o Islã —, exércitos recrutados entre os habitantes da Arábia conquistaram os países vizinhos e fundaram um novo Império, o Califado, que incluiu grande parte do território do Império Bizantino e todo o Sassânida, e estendeu-se da Ásia Central até a Espanha. O centro de poder passou da Arábia para Damasco, na Síria, sob os califas omíadas, e depois para Bagdá, no Iraque, sob os abácidas. No século X, o Califado desmoronou, e surgiram califados rivais no Egito e na Espanha, mas a unidade social e cultural que se desenvolvera em seu interior continuou. (HOURANI, 2001, p. 21)

Ao longo da pesquisa realizada para elaboração desta tese, notou-se ainda que parte da dificuldade em realizar estudos sobre assuntos ligados ao mundo árabe se dá pelo fato de que as diferentes referências bibliográficas partem de entendimentos muitas vezes distintos, excessivamente específicos ou até mesmo vagos, sobre qual seria exatamente o universo sobre o qual se deseja falar. Por exemplo, um dos grandes autores a respeito do tema, Albert Hourani, ao escrever Uma História dos Povos Árabes (1994), optou por não estabelecer nenhum tipo de definição sobre seu objeto de investigação.

Este livro trata da parte ocidental do mundo islâmico, aquela em que o árabe era a língua dominante na alta cultura e, numa forma ou noutra, na fala coloquial. Seria errado, claro, pensar que essa era uma região nitidamente isolada do mundo em torno dela. Os países de língua árabe ainda tinham muito em comum com os de língua persa e turca; as terras em torno do oceano Índico e do mar Mediterrâneo tinham estreitas ligações umas com as outras, fosse a religião dominante o Islã ou não; todo mundo vivia dentro das mesmas restrições impostas pela limitação de recursos humanos e do conhecimento técnico de como usá-los. Seria também demasiado simples pensar nessa vasta região como formando um único "país". Melhor seria pensar nos lugares onde o árabe era a língua dominante como um grupo de regiões distintas umas das outras em termos geográficos e naturais, e habitadas por povos com tradições sociais e culturais características, que ainda subsistiam em modos de vida e talvez também em hábitos de pensamento e sentimento, onde a 
consciência do que existira antes do advento do Islã enfraquecera ou praticamente desaparecera. Processos sociais mais ou menos semelhantes podem ser vistos nessas regiões, e uma língua comum e a cultura nela expressa facilitavam às classes urbanas letradas o intercâmbio umas com as outras. (HOURANI, 1994, p. 106)

O tratamento dado nesta importante publicação, escrita por um filho de libaneses e uma das maiores autoridades em história do mundo árabe, foi abordar de forma bastante detalhada e abrangente aquelas regiões do mundo islâmico cuja língua é o árabe, no período compreendido entre o aparecimento do Islã, no século XII, até o início da década de 1990.

De acordo com Clemesha (2010), quando Albert Hourani começou a lecionar história árabe, em 1951 em Oxford, não havia, segundo o prório autor, muitos livros, ou cursos, sobre os quais pudesse se apoiar.

\footnotetext{
A história árabe, ausente dos departamentos de História, era lecionada por linguistas, entre outros especialistas, reunidos nos departamentos de "estudos árabes ou orientais", onde ganharam a hoje difamada denominação de "orientalistas". (CLEMESHA, 2010, p. 89)
}

Ainda que esta tese não tenha sido conduzida com o objetivo final de se aprofundar nessas interpretações e visões sobre o assunto, seria impossível seguir adiante sem dedicar algumas páginas a essa questão. Em primeiro lugar, cabe aqui abordar o que provavelmente tem sido uma das maiores confusões por parte de algumas pessoas quando pensam e formulam opiniões sobre o mundo árabe e acabam por incluir países como a Turquia e o Irã nesse grupo. De acordo com algumas definições que serão apresentadas na próxima seção deste capítulo, os aspectos geográficos, linguísticos e culturais que configuram o rol de nações consideradas árabes, constata-se que a Turquia e o Irã costumam ser comumente e erroneamente compreendidos por algumas pessoas como árabes.

Cada uma dessas duas nações possui uma história bastante particular, e em comum com o chamado "mundo árabe" está principalmente o fato de que o Islã também é 
uma religião predominante nessas regiões, além da intrínseca expansão dessa crença, que em algum momento da história reuniu sob um mesmo espectro tais países.

\title{
2.2.2 Pequenas grandes confusões e alguns estereótipos
}

\begin{abstract}
"Sempre que havia enterro de árabe importante, mamãe mandava logo cedo um aviso às patrícias do falecido. Quem sabe se não eram conhecidos? O recado ia e mamãe, no portão, ficava esperando o resultado. Não demorava, a janela em frente se abria, uma das três moças aparecia; às vezes duas e não era raro aparecerem as três de vez: Marie, Salma e Leone. Batiam um cumprimento de cabeça, um sorriso de agradecimento pela informação. Bem-educadas, as três turcas. Em realidade, como já foi mencionado, não eram turcas - e não gostavam de ser assim chamadas - e sim, sírias ou libanesas. Mas havia o hábito de chamar-se de turco a qualquer pessoa de língua árabe, assim como de russo a todos os judeus. Os funerais árabes impressionavam pela pompa. Deles participavam os padres maronitas, figuras imponentes. Inteiramente trajados de negro, barbas cerradas e compridas, vistosos medalhões de pedrarias pendendo sobre seus ventres, longos panos esvoaçantes partindo das altíssimas tubas. Essas tubas faziam com que eles me parecessem homens imensos, amedrontadores - por mais de uma vez perturbaram meu sono. Alguns enterros de figuras de grande destaque social ou econômico rompiam o tabu, desfilando pela Avenida Paulista, a caminho do cemitério dos ricos, o Cemitério da Consolação." (GATTAI, 1979, p.47)
\end{abstract}

No Brasil, associar turcos e árabes tornou-se comum devido ao fato de que entre o final dos anos 1800 e no início dos 1900, muitos imigrantes oriundos de países como Síria e Líbano chegaram com passaportes do Império Otomano. Como o Presidente da Associação Cultural Internacional Gibran, falecido em 2013, Mansour Chalita esclarece, após o Oriente Médio ter sido ocupado entre os séculos XII e XIII pelos turcomanos oriundos da Ásia, teve início o Império Otomano, que durou oito séculos 
ininterruptos, até o fim da Primeira Guerra Mundial. A região conheceu um período de tirania e miséria e, em 1860, os turcos incitaram conflitos religiosos os quais culminaram com o massacre de muitos libaneses cristãos, o que fez com que muitos evacuassem a região montanhosa do Líbano, de maioria cristã, e que foi declarada zona autônoma do Monte Líbano.

Ainda que, após a Primeira Guerra Mundial, o Império Otomano tenha visto as partes do seu território serem desmembradas, a República da Turquia ter sido fundada em 1923 e por meio de tratados como Sevres e Lausanne, as fronteiras daquela região tenham sido redefinidas, diversos países árabes que obtiveram sua independência naquela ocasião, logo em seguida se tornaram colônias de países europeus. Ademais, por não haver uma vinda expressiva de turcos, não se observou um esforço em esclarecer esse equívoco. Ainda nos dias atuais é comum encontrar brasileiros que chamam árabes e, às vezes, também armênios e judeus, de turcos.

Jorge Amado, em seu romance A Descoberta da América Pelos Turcos, escreveu:

\footnotetext{
"Os primeiros árabes a aportar no Brasil traziam documentos do Império Turco-Otomano, de modo que eram chamados indistintamente de "turcos", fossem eles realmente turcos, libaneses ou sírios. [...] Os primeiros a chegar do Oriente Médio traziam papéis do Império Otomano, motivo por que até os dias atuais são rotulados de turcos, a boa nação turca, uma das muitas que amalgamadas compuseram e compõem a nação brasileira." (AMADO, 1994, p.26)
}

Merece menção ainda outra confusão clássica observada no Brasil ao se falar sobre os árabes, que é a associação com o Irã, em parte explicada pelo processo de expansão e retração da religião islâmica e consequentemente intercâmbio cultural experimentado ao longo dos séculos, haja vista que a antiga Pérsia também esteve sob domínio islâmico, mas também ao fato de que após a Revolução Islâmica de 1979, os conflitos políticos e religiosos nesse país passaram a ocupar posição de destaque no noticiário internacional, tendo evidenciado de forma bastante delicada, um conflito de valores que parecia se polarizar entre "Oriente" e "Ocidente". 
Neste caso, o fator religioso possui um peso fundamental, pois, tanto no Irã quanto no grupo de países que atualmente compõem o que chamaremos ao longo da tese de "Mundo Árabe" (vide tópico 2.3 deste documento) possuem o Islã como religião, se não oficial, pelo menos predominante. A conquista da Pérsia pelos árabes se deu ano 641, tendo a região que hoje se conhece como Irã passado a fazer parte do mundo islâmico. Naquele momento o islã ainda estava fortemente impregnado pela cultura árabe, não apenas pelo fato de o idioma oficial praticado pelos fiéis ser o árabe, mas porque, como dito anteriormente, os polos culturais, artísticos e científicos que eram referência para os muçulmanos, se localizavam na região de onde partiu o império, ou seja, a Península Arábica.

Outro aspecto, além da confusão entre árabes, turcos e iranianos, que também chamou a atenção ao longo da pesquisa de doutorado aqui apresentada, é o imaginário construído de forma equivocada a respeito da "mulher árabe", como se de um universo tão abrangente, fosse possível traçar um único perfil. Em 2012, o livro Arab Women in Arab News: Old Stereotypes and New Media, escrito por Amal Al-Malki, David Kaufer, Suguru Ishizaki e Kira Dreher, foi lançado, de acordo com os autores, como o intuito de refutar estereótipos das mulheres árabes como submissas, entre outras características. Por meio da análise de notícias veiculadas tanto na imprensa árabe quanto nos meios de comunicação "ocidentais", o livro buscou contrastar a forma como as mulheres são representadas, mostrando que nos jornais e noticiarios árabes o tema é tratado muitas vezes sob uma mesma perspectiva, situando-as como passivas e desprovidas da capacidade de tomar decisões. Este é apenas um dentre vários estudos os quais têm demonstrado que a mídia ocidental recorrentemente retrata as mulheres árabes como subordinadas e cumpridoras de um estereótipo orientalista de longa data.

A representação da mulher árabe é um tema que, embora não caiba a essa tese tratar de forma aprofundada, não poderia deixar de ser mencionado aqui, uma vez que ao longo da pesquisa de campo realizada entre final de 2011 e início de 2014, observou-se que o tema apareceu com frequência nos meios de comunicação, mas também durante algumas entrevistas conduzidas. A maior parte das desinformações identificadas durante a pesquisa não partiu das pessoas entrevistadas, mas foram por elas citadas como curiosidade e/ou aspectos causadores de um certo tipo de incômodo, seja porque se veem com a "tarefa" de esclarecer recorrentemente as mesmas confusões, seja porque lamentam a dificuldade ou a 
falta de interesse dos meios de comunicação em noticiar fatos relacionados ao "mundo árabe" sem aprofundar as informações de forma adequada.

A título de curiosidade, merece menção o fato de que, também em 2014, o Instituto de Pesquisa Social da Universidade de Michigan divulgou um estudo ${ }^{29}$ que provocou reações diversas devido à polêmica provocada pela pergunta "Como as pessoas em países islâmicos preferem que as mulheres se vistam em público?”. O estudo, realizado com uma amostra pouco expressiva (apenas sete países foram consultados, dos quais cinco são árabes ${ }^{30}$ ), "concluiu" que $62 \%$ dos entrevistados pensam que uma mulher não pode escolher o que vestir.

Em resposta à polêmica, Bina Shah publicou no jornal britânico The Independent um artigo intitulado "Por que o Ocidente é tão fascinado pelas roupas que as mulheres muçulmanas escolhem para usar?" (Why is the West so fascinated by the clothes Muslim women choose to wear $?^{31}$ ). Segundo a autora, enquanto os pesquisadores pensaram que eles estivessem, talvez, descobrindo uma verdade profunda sobre a opinião muçulmana em moda feminina, a pesquisa ridicularizou profundamente os muçulmanos na mídia social. Para ela, "se o objetivo de tal pesquisa tenha sido algo além de uma estranha obsessão orientalista em relação ao que as mulheres muçulmanas usam", o estudo não conseguiu cumprir seu papel.

Também chama a atenção para a dificuldade em se falar sobre a "mulher árabe" e para a existência de uma tendência a abordar o assunto de forma rasa e generalizada, a autora do livro Música árabe: expressividade e sutileza, Marcia Dib, em entrevista concedida à Revista Shimmie ${ }^{32}$, uma publicação impressa criada em 2010 dedicada à difusão de estudos, notícias e assuntos ligados à Dança Árabe no Brasil:

${ }^{29}$ Disponível em: http://exame.abril.com.br/mundo/noticias/como-o-mundo-islamico-quer-que-as-mulheresse-vistam. Acesso em: 18 set. 2013.

${ }^{30}$ Tunísia, Egito, Iraque, Líbano, Paquistão, Arábia Saudita e Turquia

31 Disponível em: http://www.independent.co.uk/voices/comment/why-is-the-west-so-fascinated-by-theclothes-muslim-women-choose-to-wear-9051281.html. Acesso em: 20 set. 2013.

${ }^{32}$ Disponível em: http://www.shimmie.com.br/. Acesso em: 9 out. 2013. 
"O mundo árabe (aqui considerado como o conjunto de países que falam o árabe) é extremamente vasto, e abarca diversos países com culturas diferentes entre si. Embora a mídia sempre aponte o mundo árabe como um bloco homogêneo, a realidade é bem diferente, existe uma diversidade enorme e aí é que está a riqueza de estudar a cultura árabe." (DIB, 2012)

Se existe certa dificuldade em se perceber que no universo de mulheres que compõem o mundo árabe não é possível tomá-las como todas dotadas das mesmas características e enfrentando os mesmos desafios, a confusão ganha novos contornos quando o aspecto religioso entra em cena. Por exemplo, no Brasil, a maioria das mulheres nascidas em países árabes ou descendentes de famílias imigrantes são de origem cristã. É expressiva a presença de mulheres muçulmanas no país, porém, é importante destacar que muitas não possuem qualquer relação com o mundo árabe, tendo se convertido ao Islã por vontade própria e já em idade adulta. Em 2012, Barros (2012) já chamava atenção para esse fenômeno no Rio de Janeiro, por exemplo:

"É bastante comum a reação de estranheza do público em geral, seja estrangeiro ou nacional, quando se fala da existência de comunidades muçulmanas no Brasil e, sobretudo, no Rio de Janeiro, lugar de praias efervescentes e clima libidinoso. Espanto que se intensifica quando vem a informação da superioridade numérica dos muçulmanos convertidos sobre os de nascimento, nessa cidade, e, ainda mais, do grande percentual de mulheres entre eles. Os estereótipos que marcam 'a mulher muçulmana' são incompatíveis com os que adornam 'a carioca'". (BARROS, 2012, p. 1)

Por si só, o tema tratado nesta seção já poderia ter sido objeto de uma pesquisa ampla. Entretanto, à guisa de conclusão, vale a pena mencionar um levantamento exploratório por mim realizado em 2010 com o intuito de verificar a quantidade de novelas em que havia presente um ou mais personagens árabes. $\mathrm{O}$ objetivo foi averiguar possíveis mudanças na forma como eles estão presentes no imaginário social da população brasileira. Tal levantamento permitiu constatar que entre 1967 e 2009 personagens árabes apareceram 
com algum destaque em cerca de 10 telenovelas nacionais. Desse total, os árabes adquiriram status de protagonistas principais em apenas duas delas, a saber: O Sheik de Agadir (1967) e $O$ Clone (2001). Um dos aspectos que mais chamou a atenção foi que após 2001, ou seja, período correspondente àquele do atentado de 11 de setembro ao World Trade Center nos Estados Unidos, a teledramaturgia brasileira levou quase uma década até contar novamente com algum personagem de origem árabe.

Curiosamente, ou não, em 2009, a emissora de televisão Record lançou Poder Paralelo, uma novela que contou com dois personagens de origem árabe, os quais inauguraram uma nova forma de representá-los na teledramaturgia brasileira ao caracterizá-los como terroristas. De lá para cá, não foi possível acompanhar com a devida atenção o eventual aparecimento de personagens árabes (e/ou muçulmanos) em novelas brasileiras, mas no final de 2013, uma polêmica envolvendo um outro folhetim, chamado de Amor à Vida (exibido pela Rede Globo de televisão) causou espanto a muita gente. Nela, o autor Walcyr Carrasco, despertou a revolta de árabes e descendentes ao introduzir uma informação à trama, que contava com um personagem palestino, o qual revelou em determinado momento da novela que havia sido terrorista, tendo inclusive cogitado ser um "homem-bomba", termo recorrentemente utilizado para se referir a suicidas que causam explosões com o intuito de matarem o maior número de pessoas possível, geralmente motivados por causas políticas ou religiosas, e planejadas por grupos ou facções radicais que assumem a responsabilidade do ato.

Se considerarmos que as telenovelas também são possuidoras de uma importância cultural e política, tendo em vista sua grande audiência e o fato de que elas deixaram de ser apenas voltadas para o lazer para se tornarem um espaço cultural de intervenção para a discussão e introdução de hábitos e valores, talvez seja possível percorrer mais um caminho para se compreender a forma como os árabes - e mais recentemente, os muçulmanos, são vistos no Brasil.

\subsubsection{Orientalismo}

Com a expansão islâmica, o termo árabe, na forma inicialmente empregada, fixou-se ao norte da África, nome esse que se dá aos países desde a Tunísia até o Atlântico. O mesmo termo teve um ponto de fixação na Península Ibérica. Durante a intensa luta dos 
países europeus contra o Império Árabe e, posteriormente contra o Império Otomano, registrou-se profunda confusão no emprego das palavras árabe, muçulmano, turco, Oriente, sarraceno, para citar alguns exemplos, e, todas elas, segundo os europeus, passaram a ter sentidos iguais: anticristão, infiel, pagão, inimigo, entre outros adjetivos.

No final da década de 1970, Edward Said em seu livro Orientalismo: $O$ Oriente como Invenção do Ocidente chamava atenção para o fato de que, na América do Norte, cada vez mais a figura do árabe aparecia por toda a parte como algo ameaçador. Por meio da desconstrução de discursos, pensamentos e imagens produzidos ao longo dos últimos séculos, com incidência especial sobre a literatura europeia do século XIX, Said procurou mostrar que o Ocidente forjou a sua própria identidade por oposição à do Oriente. Ao longo desse processo identitário, foi consolidada a idéia de que a diferença entre o Ocidente e o Oriente está na racionalidade, no desenvolvimento e na superioridade do primeiro em relação ao segundo, ao qual, por sua vez, são atribuídas características como aberrante, subdesenvolvido e inferior.

A fim de ilustrar como o trabalho de Edward Said, embora tenha sido realizado no final dos anos 1970, ainda é bastante atual, cabe aqui citar um estudo realizado por Meirinho de Souza (2010), sobre a identidade visual criada pelas imagens dos povos do Oriente Médio publicadas na National Geographic. Souza constatou que, a partir da década de 1970, com destaque para os anos 80 e 90, uma vez que que diversos conflitos na região ocuparam boa parte das agendas midiáticas, estes povos foram objeto de cobertura por parte da imprensa internacional. Segundo o pesquisador, era comum veicular a imagem desses povos de forma "bastante violenta, irracional, primitiva e carregada de preconceitos e fanatismos religiosos e políticos" (SOUZA, 2010, p. 7). Ainda segundo o estudo, após os atentados de 11 de setembro de 2001 ao World Trade Center e ao Pentágono, o interesse em relação aos povos do Médio Oriente passou a ser cada vez mais intenso.

Especialista em Oriente Médio, o professor da Universidade de São Paulo (USP) Paulo Farah considera que há uma campanha de desinformação contra o mundo árabe (FARAH, 2012) ${ }^{33}$. Ele observa que as informações e os conceitos que chegam ao

\footnotetext{
${ }^{33}$ Disponível em : http://www.sul21.com.br/jornal/ha-campanha-de-desinformacao-contra-mundo-arabe-dizpaulo-farah/. Acesso em: dez. 2013.
} 
ocidente sobre a região são generalizados e estereotipados: "A ideia de que os palestinos e os árabes em geral têm uma tendência natural à violência e ao terrorismo, por exemplo, é uma generalização completamente absurda. Ou a ideia de que os palestinos não amam os seus filhos e têm um apreço pelas armas", critica.

Cabe ainda recordar que James Zogby, presidente do Instituto ÁrabeAmericano, costuma afirmar que os problemas dos árabes antecede os atentados e está relacionado com a questão palestina. Cristão filho de libaneses, ele explica que, assim como os italianos eram erroneamente ligados à máfia, os árabes são ao terrorismo. "O conflito árabe-israelense criou o estereótipo do árabe terrorista, especialmente depois das guerras de 1967 e 1973", explica. (ZOGBY apud CHACRA, 2009) ${ }^{34}$

A noção de que existe algum tipo de "ameaça islâmica" continua permeando o imaginário de muita gente. Para a jornalista Margarida Santos Lopes, autora do Novo Dicionário do Islão (Trata-se de uma versão corrigida e aumentada, publicada em 2010, após a primeira edição ter sido lançada em 2002), "muitas vezes o nosso medo do outro tem a ver também com a nossa ignorância. O medo vai sempre subsistir". ${ }^{35}$

A título de exemplo sobre como essas ideias perpassam o cotidiano de uma sociedade, cabe aqui a citação rápida a respeito de um episódio ocorrido em 2013. Em Brasília, a exposição Mestres do Renascimento esteve aberta para visitação no Centro Cultural do Banco do Brasil entre os meses de outubro a janeiro do ano seguinte. O texto da curadoria refletia, em certa medida, detalhes que indicam e/ou sugerem a forma com que o Ocidente se relacionou com o mundo árabe, muitas vezes islâmico, ao longo dos séculos. Na cronologia disponível logo na entrada da galeria, havia, entre tantas datas importantes, uma que chamou a atenção pela forma como estava escrita: "Reconquista cristã sobre a invasão muçulmana na Espanha". A associação entre Islã e a ideia de invasão parece ter se tornado algo "natural", ao passo que, quando a ocupação se dá em direções

34 Disponível em http://blogs.estadao.com.br/gustavo-chacra/como-vivem-os-arabes-nos-eua-oito-anos-d/ . Acesso em: set. 2014.

35 Disponível em http://www.jn.pt/PaginaInicial/Sociedade/Interior.aspx ?content_id=1683842\&page=-1. Acesso em: ago. 2014. 
contrárias ela ganha outros nomes, parecendo, inclusive, minimizar alguns fatos importantes.

Cabe aqui também menção ao autor do livro 100 Mitos sobre o Médio Oriente, Fred Halliday (2005), que afirma não haver nenhum choque de civilizações, como se deseja fazer acreditar. Em seu livro, o cientista político apresenta os fatos mais correntes que os ocidentais costumam usar ao se referirem aos árabes, embora careçam de fundamentos verídicos. Halliday não desmitifica 100 teses, porém, ele mostra que algumas coisas são muito menos simplórias do que se costuma difundir. Um dos mitos citados na publicação diz respeito à frequência da guerra no Oriente Médio, nos tempos modernos, que representa a "expressão de uma antiga tradição de violência e conquista e de uma cultura que promove a violência. Abaixo, a refutação do autor para ideia não raro repetida por diversas pessoas ao se referirem àquela região:

A frequência da guerra no período pós-1945 não tem nada que ver com a frequência das guerras anteriores nem com uma "cultura de conflito" herdada dos tempos pré-modernos. Os estados, os guerreiros e os propagandistas falam muito acerca dessa continuidade, sejam os israelitas invocando o rei-guerreiro David, Saddam Hussein recordando a Batalha de Qadisiya ou os turcos apelando à memória dos seus sultões conquistadores. $\mathrm{Na}$ verdade, estas apropriações são simbólicas, e não explicações históricas. Quanto à existência de uma "cultura de violência" no Médio Oriente, trata-se de uma expressão nebulosa, quase sempre desprovida de valor analítico. Claro que há valores e práticas nestas sociedades, tais como a participação de miúdos pequenos empunhando armas em pomposos desfiles militares, que são usados para fins de mobilização e doutrinação militar, mas o mesmo se pode dizer de outras culturas - em especial as das antigas potências coloniais da Europa, bem como os Estados Unidos e o Japão. A história da Europa no século XX, bem como a brutalidade imposta por alguns dos dirigentes aos seus povos, ultrapassa em muito tudo o que podemos observar no Médio Oriente. (HALLIDAY, 2005, p. 27) 


\subsubsection{O Nacionalismo Árabe e a minimização das particularidades de cada nação}

Autora do livro Relações Internacionais do Mundo Árabe (2009), Silvia Ferabolli chama atenção para o fato de que "desde a formação do Sistema Árabe de Estados, na esteira do processo de descolonização, a retórica nacionalista árabe, ou panarabista, tem sido o pano de fundo sobre o qual as relações políticas intra-árabes se desenvolveram” (FERABOLLI, 2007). Segundo ela, é “creditada ao principal teórico do Ba'th, Michel 'Aflaq, a definição do conceito e dos termos que viriam a definir o que seria o pan-arabismo: 'Só há uma nação árabe, com direito a viver num único Estado unido"” (HOURANI apud FERABOLLI, 2007, p. 67).

Ainda segundo a pesquisadora, para fins de análise, é possível tomar os termos pan-arabismo e nacionalismo árabe como semelhantes, o discurso pan-arabista tende a tratar todos os árabes como uma comunidade imaginada, caracterizada pelo compartilhamento de uma mesma língua, cultura e história e que, consequentemente, deveriam estar unidos em torno de um único Estado-nação. Contudo, acrescenta, "as relações entre os Estados que formam aquilo que se denomina 'Mundo Árabe' sempre estiveram muito aquém da unidade, tendo se caracterizado mais pela desintegração.” (idem)

Essa perspectiva inundou o debate político e econômico global desde que a Liga Árabe tentou promover a cooperação intra-árabe, em 1950, por meio da assinatura do Tratado da Junta de Defesa e Cooperação Econômica, cujo objetivo era promover uma ação coordenada que garantisse o desenvolvimento econômico dos signatários e deu sequência à assinatura de outros 4 tratados. Porém, a gênese do nacionalismo árabe se deu décadas antes, em Damasco, mais precisamente no final do século XIX, quando movimentos intelectuais clamavam por uma identidade árabe, pautada em uma espécie de "despertar". O conceito de "mundo árabe" origina-se nesse contexto, em que para ser tomado como árabe, não era necessário mais do que falar o idioma, olhar para a história dos árabes com orgulho e se considerar como tal. (KHALIDI apud FERABOLLI, 2007, p. 11).

Já Vicenzi (2006), que também usa a expressão nacionalismo árabe em consonância com pan-arabismo, define este movimento como focado na "unificação política dos povos de língua árabe, cuja ideologia é marcada pela crença de que todos os 
árabes compartilham uma história, uma cultura, uma língua" (VICENZI, 2006, p. 1). Para a autora, o nacionalismo é um tema extremamente complexo e de difícil síntese. De acordo com a autora, que opta por tratar a questão do nacionalismo como "a diversidade de casos nacionais ao longo do tempo e do espaço contribuiu para a ausência de consenso analítico ao redor desse fenômeno" (idem, p. 6).

Este movimento, cuja ascenção se deu de forma rápida, porém, extremamente tumultuada, não tardou em ser contestado. Para Kramer (1993), uma das principais causas para o declínio teria sido sua amplitude frente à busca pelos Estados territoriais por suas identidades próprias. Para o autor, já no final da década de 1960, apenas alguns intelectuais conseguiam colocar em prática a proposta idealizada no âmbito do nacionalismo árabe que, para ele, se configurou em uma utopia.

Indo nessa mesma direção de pensamento, porém oferecendo mais críticas ao tema, o economista de origem iraquiana, autor do livro El Mundo Arabe y Occidente: el petroleo de rodillas, Mazhar al-Shereidah (1995) também rebate a ideia de nacionalismo árabe. Em matéria publicada pelo jornal venezuelano El Mundo, o escritor argumenta que, assim como a primavera árabe é uma invenção imperialista, o nacionalismo árabe foi um invento imperialista, basicamente anglo-francês. Para ele, ser árabe ou sentir-se árabe é uma idealização cujo conceito talvez pudesse existir no subconsciente das massas que promulgavam a irmandade entre os árabes; mas, no imaginário coletivo regional, surge hoje a convicção de que falar sobre eles é falar sobre um fantasma, pois a chamada "Nação Árabe" é algo inexistente, uma utopia. Samir Kassir, jornalista e escritor libanês que teve sua vida interrompida em um atentado em 2005 em Beirute, um ano antes publicou um importante livro que propunha uma reflexão sobre como os árabes veem a si próprios. Em Being Arab, livro que foi publicado em português sob o título Considerações Sobre a Desgraça Árabe, o autor também se coloca contra a ideia de nacionalismo.

Para Kassir, não é agradável ser árabe nos dias de hoje. Depois dos dias de glória, dos califados e impérios transcontinentais, os árabes são vítimas de si próprios. Perseguições, ódio, condições econômicas e sociais precárias, apelos ao terrorismo. E, segundo o autor, o nacionalismo só agravou o problema (KASSIR, 2013, p. 46), pois foi edificado com base numa cultura imperialista que, na esteira dos neoconservadores americanos, acredita que a mudança e a democratização só podem vir dessa dominação, 
sem verem que desse modo só agravam as frustrações e alimentam a vitimização e a cultura de morte, tornando perene a desgraça árabe.

\subsection{O mundo árabe no cenário político a partir do século XX - A Liga dos Estados Árabes}

Atualmente, um país árabe, de acordo com a Liga dos Estados Árabes, é um país que tem como oficial a língua árabe e que se baseia nas leis muçulmanas. A liga é uma organização de estados árabes fundada em 22 de março de 1945 no Cairo por seis países por ordem de assinatura do documento de fundação: Egito, Iraque, Jordânia, Líbano, Síria e Arábia Saudita. Seu objetivo é reforçar e coordenar os laços econômicos, sociais, políticos e culturais entre os seus membros, assim como mediar disputas entre estes.

De acordo com informações de agosto de 2014, a Liga Árabe compreendia vinte e um estados, que possuíam no total uma população superior a 200 milhões de habitantes. A participação da Síria, que totalizava 22 nações reunidas pela Liga, foi suspensa em novembro de 2011 por causa da guerra civil em curso no país, numa votação em que a Síria, Líbano e Iêmen foram contra, enquanto o Iraque se absteve.

Embora seja considerada pelas Nações Unidas uma organização regional, tal classificação não corresponde à realidade, visto que seus Membros estão espalhados pelos continentes africano e asiático. Originalmente, o principal fator de união era a vinculação com o mundo árabe como um primeiro passo árabe, dentro de uma nova configuração de Estados independentes na busca de sua própria posição no contexto internacional. Porém, a religião islâmica paulatinamente passou a ser um importante elo entre os países pertencentes à liga, sobrepondo-se à uma ideia de cultura árabe que, embora não fosse homogênea, era pautada pela questão do idioma, reconhecimento de uma identidade, entre outros aspectos.

O quadro a seguir mostra os países integrantes da Liga dos Estados Árabes e a data de sua inclusão. Países como Mauritânia, Somália, Djibouti, Comores ${ }^{36}$ e Eritreia, que aderiu à Liga Árabe na qualidade de observador em 2003, são atualmente considerados

\footnotetext{
${ }^{36}$ República Federal Islâmica das Comores, também conhecido como Ilhas Comores.
} 
árabes embora culturalmente tenham pouca relação com os demais, os quais, embora não estejam todos localizados na Península Arábica, passaram há alguns séculos por um processo de "arabização". Este contexto coincide com o momento em que a religião islâmica, estando fortemente impregnada por um projeto de expansão de um império, extrapolou as fronteiras locais e alcançou regiões bastante longínquas, mas que mantiveram uma identidade cultural bastante forte.

\begin{tabular}{|c|c|}
\hline País & Data de adesão \\
\hline Egito & 22 de março de 1945 \\
\hline Iraque & 22 de março de 1945 \\
\hline Jordânia & 22 de março de 1945 \\
\hline Líbano & 22 de março de 1945 \\
\hline Arábia Saudita & 22 de março de 1945 \\
\hline Síria & 22 de março de 1945 \\
\hline Iêmen & 5 de maio de 1945 \\
\hline Líbia & 28 de março de 1953 \\
\hline Sudão & 19 de junho de 1956 \\
\hline Marrocos & 1 de outubro de 1958 \\
\hline Tunísia & 1 de outubro de 1958 \\
\hline Kuwait & 20 de julho de 1961 \\
\hline Argélia & 16 de agosto de 1968 \\
\hline Emirados Árabes Unidos & 12 de junho de 1971 \\
\hline Bahrein & 11 de setembro de 1971 \\
\hline Catar & 11 de setembro de 1971 \\
\hline Omã & 29 de setembro de 1971 \\
\hline Mauritânia & 26 de novembro de1973 \\
\hline Somália & 14 de fevereiro de 1974 \\
\hline Palestina & 9 de setembro de 1976 \\
\hline Djibouti & 9 de abril de 1977 \\
\hline Comores & 20 de novembro de1993 \\
\hline Eritreia & observador desde 2003 \\
\hline
\end{tabular}

Quadro 2 - Data de adesão dos países à Liga dos Estados Árabes 
A Liga dos Estados Árabes inseriu-se no cenário das relações internacionais com propostas ambiciosas voltadas para consolidação de um projeto nacionalista. $\mathrm{O}$ Artigo $1^{\circ}$ da Carta de Fundação da Liga dispõe que "todo o Estado árabe independente tem o direito de tornar-se membro da Liga, se ele assim desejar”. A atuação da entidade, no entanto, em episódios determinantes como a invasão dos Estados Unidos da América ao Iraque, o conflito na Síria ou o processo de paz entre Israel e Palestina, tem sido alvo de muitas críticas por parte de intelectuais, políticos, analistas e também cidadãos dos países pertencentes à Liga, que não a tomam como um representante legítimo.

Nesse caso, observa-se um hiato entre o papel supostamente assumido pela Liga dos Estados Árabes e a forma como ela se inseriu no cenário internacional nas últimas décadas. Diante desse contexto, uma questão importante é: que outra instituição formal pode ou deseja ser tomada como representante dos interesses dos países árabes? E, de modo contíguo a essa pergunta, pode-se levantar um outro ponto importante, difícil de ser respondido: até que ponto é interessantes às nações árabes estarem reunidas sob uma entidade que supostamente agregaria os mesmos interesses, mas que, na prática, termina por revelar disparidades culturais, políticas e sociais entre os países, revelando a imensa dificuldade em se compreender quem efetivamente são os árabes no cenário atual? 


\title{
CAPÍTULO 3 \\ A PLURALIDADE DA PRESENÇA ÁRABE NO BRASIL
}

\begin{abstract}
O capítulo anterior mostrou a estreita associação entre religião islâmica e mundo árabe, embora seja impossível tratar muçulmanos e árabes como sinônimos, especialmente após tantos séculos desde o surgimento dessa fé. De fato, o Islã nasceu na chamada Península Arábica, a qual foi unificada ${ }^{37}$ pelo Califa Omar no ano 634, seguida pela conquista de Damasco, na Síria, que culminou com a vitória dos árabes sobre os bizantinos no Vale de Iarmuk (SALINAS, 2009, p. 234).
\end{abstract}

O contato direto dos árabes islamizados com as grandes civilizações da Antiguidade - gregos, romanos, persas e bizantinos - modificou a identificação puramente étnica do islamita, de maneira que todos eram reputados árabes, independentemente de sua nacionalidade. Bastava a filiação religiosa e a adoção da língua árabe para completar a transformação (idem, p. 113).

Ainda segundo Salinas (p. 53), o islamismo propunha unificar os árabes de um ponto de vista religioso e, inevitavelmente, propiciar a formação de unidade política. Não havia, porém, um "propósito de submeter outros povos à religião muçulmana, compelindoos pela força", e muito menos o objetivo de aniquilar a civilização dos povos com quem tiveram contato durante o período de expansão do Islã e de quem assimilaram muitos dos conhecimentos posteriormente difundidos naquele grande império. $\mathrm{O}$ autor acrescenta também que, embora islamismo e política não fossem concomitantes desde o primeiro século da conquista, "é exponencial anotar que, excetuada a Península Ibérica, a religião islâmica permaneceu firmemente implantada no solo onde consolidou a sua presença". Neste sentido, seria impossível falar sobre a presença árabe em diversos povos sem levar

\footnotetext{
${ }^{37}$ Do ponto de vista político, até o século VI, os árabes se organizavam de forma descentralizada, e a região era dividida em tribos, que até então jamais haviam se consolidado em torno de uma instituição política unitária.
} 
em conta as intersecções culturais experimentadas especialmente no período de ascensão do Império Islâmico.

De modo geral, a revisão bibliográfica feita para esta pesquisa aponta para o fato de que, ao falarmos sobre presença árabe no Brasil, há de se ter em conta dois tipos de dados: (i) aqueles que tratam a questão da vinda de libaneses e sírios, mas também palestinos e imigrantes de outros países árabes, porém em menor escala - deslocamento este que ainda segue em curso, ainda que seu fluxo tenha se reduzido consideravelmente; e (ii) uma herança cultural trazida a partir do século XVI, por portugueses e espanhóis à América do Sul como um todo - período que coincide com o arrebatamento do último reduto muçulmano na Espanha, o reino de Granada.

Sobre o primeiro ponto, vale a pena mencionar que não se sabe ao certo o volume de árabes que desembarcaram no Brasil nos últimos 100 anos. As estatísticas oficiais são bastante descontínuas (AKMIR, 2009, p.21) e isso dá margem para a estimativa de valores bastante díspares em relação ao número de imigrantes e seus descendentes no Brasil. Nesse sentido, números e dados estatísticos são insuficientes, para não dizer frágeis, quando o intuito é falar sobre essa presença no Brasil.

Soma-se a isso, o fato de que tratar a respeito dos árabes em nossa cultura é ir muito além de censos e registros de fluxo migratório, pois, como mencionado anteriormente e como será melhor tratado adiante, de alguma forma eles já estavam entre nós desde muitos séculos antes da chegada dos imigrantes a partir da segunda metade do século XIX.

As Ciências Sociais contam ainda com poucas publicações voltadas para esse assunto, especialmente no tocante à hipótese de que tal presença teria antecedido a chegada dos próprios imigrantes e, possivelmente minimizado as chances de choques culturais muito fortes quando da sua chegada. O levantamento feito para elaboração deste projeto apontou para o fato de que estudos a respeito deste tema, ao tratarem apenas a questão da imigração de árabes no país, acabam por limitar a análises mais profundas quanto à existência ou não de conflitos relacionados à sua chegada. 


\subsection{A presença árabe no Brasil pela via da imigração}

[...] a imigração árabe para o Brasil sofre dos mesmos problemas em relação a outros grupos migratórios do país, mas é ainda mais agravado pela própria definição e identificação de quem são, quantos são e onde estão os indivíduos que fazem parte desse grupo genericamente chamado árabe ou ainda "turco". Nos censos demográficos brasileiros, esse grupo imigrante foi enquadrado no termo genérico "outras nacionalidades" ou na categoria de "vários". Quando referidos em suas nacionalidades a confusão é grande, pois recebem diferentes denominações: árabes, turcos, turcos-árabes, sírios-libaneses, sírios e libaneses, sírios-libaneses "não turcos". Embora sírios e libaneses tenham sido a grande maioria dentre os povos de origem árabe que para cá vieram, essa ampla e confusa generalização desconsiderava a presença de outros grupos menores como egípcios, palestinos, iraquianos, marroquinos. Além disso, diluía sua importância numérica em relação a outros grupos de maior expressão, levando também ao problema da análise estatística, pois os dados não coincidem e em um mesmo censo foram usadas duas ou mais categorias. $\left(\right.$ OSMAN, 2009) ${ }^{38}$

É possível tomar o decreto de 25 de novembro de 1808, de D. João VI, como um importante ponto de partida para investigações acerca do tema da imigração para o Brasil, pois aos estrangeiros lhes fora concedido o acesso à propriedade de terra. Pouco depois, já independente, o país atraiu imigrantes de distintas nacionalidades, sendo que em alguns casos os fluxos migratórios contaram com o apoio e subsídios do governo brasileiro. Em 1818, era assinado o Tratado de Colonização, que marca, segundo Seyferth (2007, p. 14), “o início do processo de colonização com imigrantes europeus, depois da independência, voltado, principalmente (mas não exclusivamente), para a ocupação de terras devolutas no sul do país".

38 Artigo publicado pelo Instituto de Cultura Árabe ICArabe em 2009. Disponível em: http://www.icarabe.org/artigos/registros-da-experiencia-na-historia. Acesso em: jan. 2014. 
O fenômeno da imigração para o Brasil alcançou seu apogeu entre meados do século XIX e as primeiras décadas do século XX e, muito embora estudos apontem que a presença dos imigrantes árabes e de outras nacionalidades proporcionou uma espécie de pluralismo étnico e cultural no país, argumenta-se (LESSER, 2001) que era evidente a preferência das elites em relação à vinda de europeus - pois acreditavam que seu ingresso contribuiria para uma espécie de transformação social.

Segundo o historiador Jeffrey Lesser, "a partir de cerca de 1850, quando se tornou claro que a escravidão não perduraria por muito tempo, a imigração passou a desempenhar um papel central nas políticas públicas”. Dados dão conta de que entre 1872 e 1949, para cerca de quatro milhões de migrantes europeus ingressos no Brasil, pouco mais de 400 mil eram classificados, de acordo com as estatísticas da época, como asiáticos, árabes ou judeus (LESSER, 2001). Cabe acrescentar ainda que no século XX, a necessidade de mão de obra para a indústria passou a ser determinante para o incremento dos processos migratórios, o que ocasionou também a vinda espontânea de determinados grupos.

Apesar do empenho do governo imperial - que até o final da década de 1870 utilizou o trabalho de agenciadores (contratados para trazer imigrantes da Europa, recebendo pagamento per capita, calculado de acordo com a idade e o sexo) e aprovou, por decretos, muitas propostas de núcleos coloniais apresentadas por empresas particulares (indicadores do interesse pela ocupação territorial) - a imigração em massa só ocorreu na República, especialmente no período entre 1887 e 1914, quando aportaram no Brasil quase três milhões de imigrantes. (SEYFERTH, 2007, p. 21)

Antes do fenômeno dos grandes fluxos migratórios para o Brasil, ainda no período compreendido como "Brasil Colônia", eram proibidos de entrar no país os chamados "heréticos", denominação dada aos muçulmanos e judeus. Importante ressaltar que, no entanto, naquela época era comum permitir e tolerar a existência de "cristãos novos" e até mesmo "marranos", ou seja, pessoas recém-convertidas ao cristianismo e cristãos que secretamente ainda mantinham sua outra religião - respectivamente. Já após 
1822, com a independência do Brasil em relação a Portugal, permitiu-se a prática de outras religiões cristãs não católicas. Mas, ainda assim, registrava-se entre a população nativa um grande desafeto em relação aos estrangeiros (LESSER, 2001). No entanto, esta tensão ficaria ainda pior quando, em 1889, o primeiro decreto do governo já na condição de República, proibiu terminantemente a entrada de asiáticos e africanos. Essas medidas repercutiram em debates entre intelectuais e políticos sobre a questão da imigração e seu "projeto" de recriação do Velho Mundo no Novo, sobre questões raciais e o projeto de consolidação da nação.

De acordo com Truzzi (2000, p. 316), entre 1880 e 1930, a maior parte de sírios e libaneses que se deslocavam em direção à América aportava nos Estados Unidos. No Brasil, sua chegada se acentua às vésperas do século $\mathrm{XX}$, atingindo seu auge no período que antecede a Primeira Guerra Mundial. Após um período de interrupção no processo migratório durante a guerra, o fluxo é retomado por volta de 1920, voltando a decair no início da década seguinte.

Muito embora o ambiente social e político brasileiro não tenha promovido declaradamente a vinda de determinados povos, a história do Brasil foi marcada pela chegada espontânea e sistemática de árabes - em sua maior parte sírios e libaneses - para o país. Não apenas isso, mas estudos têm indicado que tal processo foi marcado por uma bem sucedida integração à cultura local, do ponto de vista da ausência de registros significativos de situações de conflitos sociais provocados por questões étnicas. Pelo contrário. Segundo a arabista Claude Fahd Hajjar (2014), “o Brasil foi o país que sediou e possibilitou a profícua produção das letras árabes. Constatamos a existência de mais de 140 jornais e revistas e mais de 300 jornalistas, até o ano de 1949". Ademais, o fluxo foi tão intenso que, atualmente, sabe-se que a maior colônia libanesa fora do Líbano se encontra no Brasil.

Estima-se que entre árabes e descendentes, o Brasil conte atualmente com mais de 6 milhões de pessoas, embora seja importante salientar que esta estimativa é bastante imprecisa e varia fortemente, chegando ao número de 14 milhões, a depender da fonte consultada. Segundo Zaidan (2001, p. 95), "segundo pesquisas, nas Copas do Mundo de 
Futebol, depois do próprio brasileiro, os libaneses formam a maior torcida pelo time do Brasil". 39

A vinda dos árabes, iniciada mais precisamente em 1871, fez-se tradicionalmente com moradores do campo, lavradores ou proprietários de terras. Além do mais, diferentemente das levas migratórias italianas, espanholas e portuguesas, cuja chegada era acompanhada por uma expectativa de se "mudar a composição social do Brasil, os sírios e libaneses vieram por conta própria e sem alarde” (LESSER, 2001).

Merece menção, ainda, o fato de que Dom Pedro II foi um grande admirador da literatura e da cultura árabe, e chegou a ter contato com a língua árabe no Brasil ao estudar com um arabista alemão. Sabe-se que o Imperador esteve no Líbano acompanhado de sua esposa e de uma comitiva com aproximadamente 200 pessoas entre 11 e 15 de novembro de 1876. De acordo com informações do Arquivo Histórico de Estrasburgo - França, o Imperador escreveu ao seu amigo, o diplomata francês Joseph Gobineau: "Tudo vai bem... A partir de hoje começa um mundo novo. O Líbano ergue-se diante de mim com seus cimos nevados, seu aspecto severo, como convém a essa sentinela da Terra Santa...". ${ }^{40}$

${ }^{39}$ Corroborando a informação dada por Zaidan, cabe mencionar que em 2014, na ocasião da realização do campeonato futebolístico no Brasil, diversos portais de notícia mencionaram a empolgação da torcida libanesa pelo time brasileiro. Disponível em: https://br.esporteinterativo.yahoo.com/fotos/jovens-libanesesformam-torcida-pelo-photo-085302997.html e http://tvuol.uol.com.br/video/jovens-libaneses-formamtorcida-pelo-brasil-0402CC993668DC815326. Acesso em: jan. 2014.

${ }^{40}$ Disponível em: http://www.libano.org.br/libano_brasil_donpedro.htm. Acesso em: jan. 2014. 


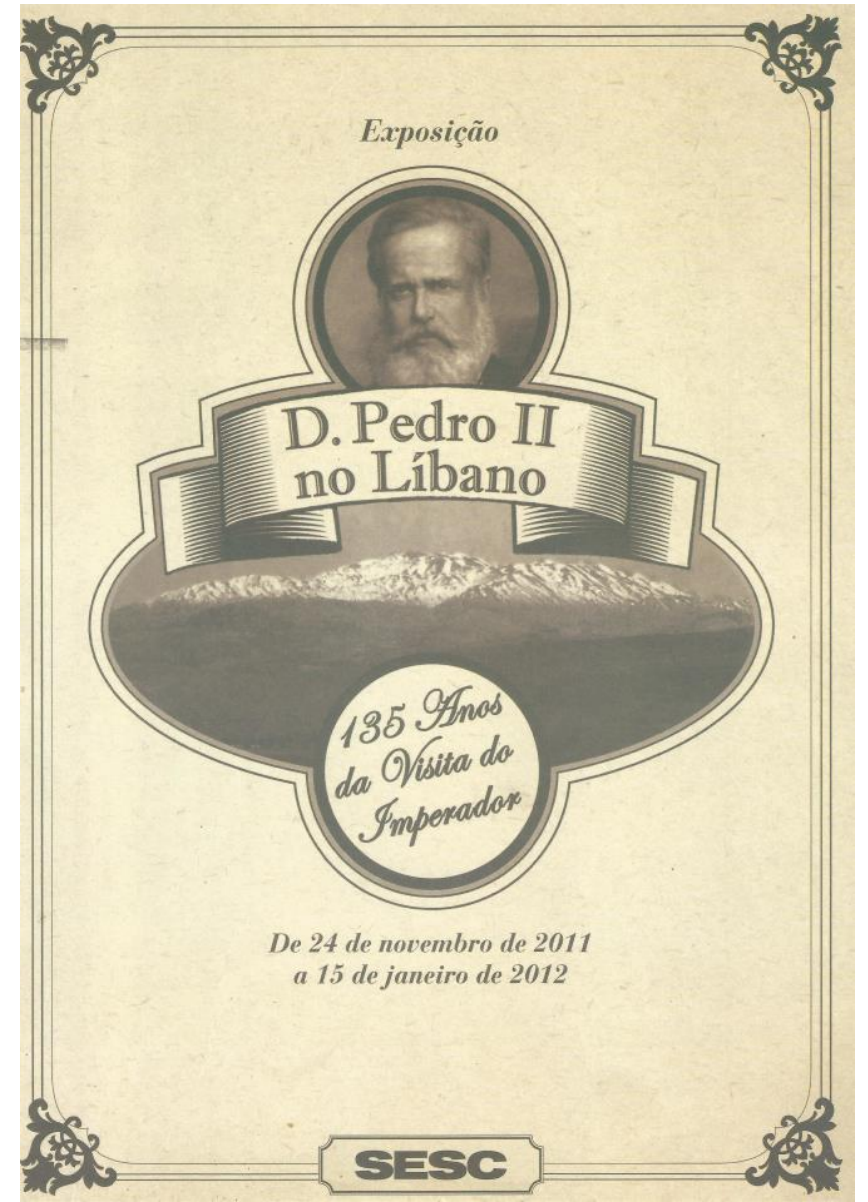

Figura 4 - Folheto de divulgação da Exposição D. Pedro II no Líbano - 135 anos da Visita do Imperador 41

As obras mantidas pelo imperador brasileiro em seu acervo pessoal, no idioma árabe ou sobre os árabes, atualmente fazem parte da coleção da Biblioteca Nacional, no Rio de Janeiro e foram catalogados pelo pesquisador e professor João Baptista Vargens, resultando no livro "D. Pedro II, o primeiro arabista do Brasil?", lançado em 2013 pela editora de Vargens, a Almádena, especializada em livros sobre a temática árabe.

De acordo com PINTO (2005), os primeiros imigrantes eram de maioria cristã (maronitas, ortodoxos e melquitas ${ }^{42}$ ) e eram originários de países árabes do Oriente Médio,

\footnotetext{
${ }^{41}$ Exposição realizada entre 24 de novembro de 2011 e 15 de janeiro de 2012 no SESC Vila Mariana em São Paulo (SP).
} 
em especial Líbano, Síria e Palestina, embora, naquele momento tais países não existiam como tal. ${ }^{43}$ Segundo Montenegro (2009), a identidade de origem estava configurada em relação às religiões professadas nas aldeias de onde vinham os imigrantes, sendo que a maioria era composta por cristãos, que tentavam se afastar do jugo otomano. As primeiras duas décadas do processo migratório foram consideradas pelos chegados como algo temporário. As cartas enviadas a seus familiares e o próprio retorno de alguns imigrantes tão longo conseguiam reunir uma quantidade satisfatória de capital demonstram que o objetivo inicial dessas pessoas era melhorar a situação de suas famílias na terra natal, ainda que muitos tenham ficado no Brasil. A autora divide os fluxos migratórios da seguinte forma: a década de 1880 corresponde à chegada dos primeiros imigrantes árabes, ainda que a partir de 1900 a imigração tenha sofrido um declínio, para depois se intensificar no período entre 1914 e 1940. Após a segunda grande guerra, o processo migratório recomeça e, já entre 1975 e 1990, observa-se um novo fluxo, o qual se mantém ativo até o momento presente.

Gattaz (2012), em estudo específico sobre a presença libanesa no Brasil, divide, por sua vez, quatro momentos da imigração originária desse país. O primeiro deles vai de 1880 a 1920 e é marcado por cristãos que tentavam escapar do domínio otomano, grande parte caracterizada por uma população rural. A segunda etapa corresponde ao período entre guerras 1920 e 1940. Nessa ocasião, vieram não apenas cristãos, mas também muçulmanos que buscavam melhorar suas condições de vida. A terceira etapa é aquela entre 1940 e 1975, já com o Líbano independente e uma população motivada em deixar suas terras devido à depressão econômica pós-segunda guerra mundial, mas também devido aos conflitos de ordem religiosa e política. Por fim, a quarta etapa inicia-se em 1975 e estende-se até o início do século 21, e está vinculada à Guerra Civil no Líbano e à

\footnotetext{
42 “Os maronitas são ligados ao Vaticano, mas respeitam como principal autoridade o patriarca maronita, baseado no Líbano. A liturgia é em siríaco. Os melquitas são católicos que seguem um rito próprio. Os ortodoxos seguem a Igreja Ortodoxa da Grécia e da Síria”. (CHACRA, 2005)

${ }^{43}$ A Síria só viria a se tornar independente em 17 de abril de 1946, e o Líbano, em 22 de novembro de 1943, embora as tropas francesas tenham se retirado três anos depois.
} 
ocupação de territórios por parte de Israel. Nesse caso, nota-se uma predominância de imigrantes muçulmanos sunitas e xiitas, embora também tenham vindo alguns cristãos.

Para Hajjar (1985), o deslocamento dos árabes para o Brasil é frequentemente registrado em duas grandes etapas, sendo que cada uma delas foi formada por diferentes levas migratórias. A primeira teria se iniciado por volta de 1860/1870 e terminado com o início da Segunda Guerra Mundial. Dentro desse período, são percebidos três fluxos: de 1860 a 1900; de 1900 a 1914, e de 1918 a 1938. Já a segunda etapa, cujo início se deu em 1945, continua até os dias atuais. Nesse segundo momento, são identificadas outras três levas imigratórias, que dão sequência aos fluxos anteriores. São elas: de 1945 a 1955; de 1956 a 1970, e, por fim, a última leva, que teve início por volta de 1971 e prossegue ainda hoje.

De modo geral, a principal diferença entre as duas grandes etapas do processo migratório árabe para o Brasil é que a primeira foi marcada por imigrantes cristãos majoritariamente sírio-libaneses que teriam deixado suas terras por causa do domínio otomano, enquanto que a segunda teve início após a segunda grande guerra e é composta por grupos mais heterogêneos - cristãos e muçulmanos oriundos de um maior número de países árabes. Convém lembrar que em comum entre as diferentes levas migratórias, podese citar o fato de que essa imigração está pautada pela espontaneidade, ou seja, não houve nenhuma participação direta do governo ou de outras forças que promoveram esse fluxo. Tal fenômeno é explicado em razão de que durante muitos anos seria impossível que os governos dos países árabes participassem de algum acordo, uma vez que seus Estados conquistaram sua soberania após a segunda grande guerra.

Importante acrescentar, ainda, que a partir da quinta leva migratória, que teve início poucos anos antes da década de 1960, destaca-se uma significativa entrada de palestinos, os quais se instalaram, de modo geral, em cidades distintas daquelas que anteriormente haviam recebido boa parte dos imigrantes anteriores. $\mathrm{O}$ sul do país destacouse como uma nova rota, sendo Foz do Iguaçu o mais recente e principal ponto de atração, especialmente de famílias muçulmanas. Esse movimento foi reforçado na década seguinte, quando teve início a sexta e última leva migratória, que se assemelha à anterior - exceto pelo fato de que, a partir dos anos 1970, muitos atos revolucionários de guerrilheiros 
palestinos iniciaram-se por todo o mundo - alterando sobremaneira a inserção do árabe nos países para os quais migravam.

A literatura acerca da história da imigração árabe para o Brasil aponta para novas levas migratórias ocorridas após a década de 1970, as quais foram marcadas por outras características, diferentes das anteriores. No caso dos imigrantes que procediam principalmente do Líbano, cabe ressaltar que, inicialmente, deixavam seus países devido à guerra civil no país (1975-1990). Já o deslocamento palestino tem relação profunda com as políticas de ocupação israelense aplicadas em Gaza e na Cisjordânia.

O Brasil foi um dos países de destino para muitas famílias e é importante salientar o fato de que, ao chegarem, já encontraram comunidades árabes preexistentes arraigadas e com suas próprias percepções comuns sobre imigrantes, o que gerou uma nova dinâmica social e cultural. Ademais, ao contrário dos seus predecessores da primeira metade do século XX, os novos imigrantes, que marcaram presença após 1970, eram em sua maioria muçulmanos, muitos xiitas - especialmente os do sul do Líbano - porém, a maior parte sunita.

Entretanto, de acordo com o coordenador de pesquisa de pós-graduação em Antropologia e do Núcleo de Estudos sobre o Oriente Médio da Universidade Federal Fluminense, Paulo Gabriel Hilu da Rocha Pinto (PINTO, 2009), além do aspecto religioso, observa-se a existência de outros fatores de diferenciação com relação às primeiras levas migratórias. Um deles caracteriza-se pelos vínculos escassos com suas regiões de origem mantidas pelos primeiros, sendo que tais laços iam se enfraquecendo conforme sua inserção na sociedade brasileira (por meio de casamentos, amizades, mobilidade social, entre outros fatores). Por outro lado, os imigrantes árabes recentes parecem ter preservado os vínculos com seus países de origem, aspecto este que foi muito favorecido pelas facilidades tecnológicas das últimas décadas, que permitem a comunicação de forma rápida e imediata, além das facilidades para viajar, entre outros aspectos.

Consequentemente, a dinâmica de negociação e construção das identidades árabe e brasileira experimentou importantes mudanças que exigem uma revisão crítica do velho modelo de "integração cultural", se segundo este antigo modelo, os imigrantes e seus descendentes deviam renunciar a seus traços culturais distintivos para abraçar a identidade local, a observação empírica da realidade atual mostra um complexo processo de 
hibridação cultural e construção de identidades múltiplas e mobilizadas alternativamente dependendo da situação concreta. (PINTO, 2009, p. 193)

No tocante à ocupação dos imigrantes árabes, o comércio e a venda ambulante (cuja atividade passou a ser associada aos mascates) lhes permitiu ocupar um importante papel na vida econômica brasileira, seja em meio urbano ou rural. Vilela (2011, p. 160) chama atenção para o fato de que a grande maioria dos sírios e libaneses que deixavam seus países em direção à América eram homens, solteiros, com a determinação de alcançar riqueza e retornar à terra natal. Nesse sentido, a atividade de mascate, embora demandasse bastante esforço físico, era uma boa opção de ocupação para esses imigrantes que, em virtude de chegarem desacompanhados, podiam viajar por longos períodos pelo interior do país, além de permitir que fossem autônomos, o que facilitaria, em última instância, "o posterior retorno ao país de origem, pois, sem contratos, não tinham acordos a cumprir". (idem)

Cabe acrescentar que a presença árabe nas redes comerciais por eles construídas foi fator deveras importante para a integração da economia nacional, ligando lugares mais afastados, dispersos no vasto interior do Brasil. Estudos realizados por Truzzi (1997) e Safady (1994), entre outros, apontam que os sírios e libaneses vieram com a intenção de se dedicar a atividades propícias à obtenção de lucros rápidos, com os quais eles pretendiam retornar às suas terras de origem. Em outras palavras, os árabes que se voltaram para o Brasil não buscavam as fábricas ou as propriedades agrícolas, tendo se dedicado, em grande parte, ao comércio e às pequenas indústrias (HAJJAR, 1985). Esse desejo esteve presente durante todos os movimentos de adaptação e todos os passos de construção da sua vida neste país.

A prática mais recorrente era a de que, tão logo os mascates conseguissem acumular recursos financeiros, compravam um burro de carga para que pudessem deixar de viajar a pé. Em seguida, iam acomodando-se pelas cidades do interior, especialmente aquelas onde houvesse freguesia que lhes possibilitasse estabelecer um pequeno negócio. Já com as lojas próprias, era comum que continuassem a vender produtos semelhantes àqueles que costumavam mascatear, ou seja, de tudo um pouco. Famosos armarinhos, lojas de tecido e ferragens nas pequenas cidades pertenciam a sírios ou libaneses. 
Sírios e libaneses concentraram-se, principal mente, nas capitais dos estados da região sudeste do país. Além disso, estabeleciam seus negócios em locais específicos das cidades. Em São Paulo, na rua 25 de Março; no Rio de Janeiro, próximo à Praça Tiradentes; e, em Belo Horizonte, na rua dos Caetés. Esses são locais estratégicos, como notado por Knowlton (1960), porque ligam o centro da cidade diretamente às estações de trem e/ou rodoviárias, "assegurando constante passagem de potenciais consumidores". (HAJJAR, 1985, p. 161)

Ainda que exista alguma dificuldade em se analisar os dados estatísticos da época devido às suas imprecisões e interrupções nos registros, é possível afirmar que o período de maior fluxo migratório árabe, especialmente sírio-libanês, foi entre 1920 e 1930 (CAMPOS, 1987), tendo o estado de São Paulo se destacado como principal centro de absorção de imigrantes - calculado entre $38,4 \%$ e $49,0 \%$ do total, respectivamente.

Knowlton (1955), Hajjar (1985), Souza (2002), Koraicho (2004) em seus respectivos estudos apontam a concentração árabe na região central de São Paulo, mais especificamente na 25 de Março e em suas adjacências como Ladeira Porto Geral, e as ruas Cav. Basílio Jafet, Comendador Abdo Schahin, Barão de Duprat, Afonso Kherlakhian (antiga Pagé), Senador Queiróz, Carlos de Souza Nazaré (antiga Anhangabaú), entre outras que compõem o cenário geográfico do local. Tal região é apontada e ainda hoje identificada na cidade como a "rua dos árabes" a despeito das transformações ocorridas, revelando uma forte vinculação identitária. Tal identificação levou, inclusive, à criação em 2008 pelo Senado Federal, do Dia Nacional da Comunidade Árabe no Brasil a ser comemorado no dia 25 de Março. (OSMAN, 2009, p. 3)

A importância da cidade de São Paulo como principal receptora de imigrantes sírios e libaneses no Brasil, no século XX, tem sido ressaltada em diversos estudos e publicações acerca do tema, com destaque para a Rua 25 de março, cujo nome também deu origem à data escolhida para se comemorar o dia oficial da comunidade árabe no Brasil. Em torno dessa data, já se percebem alguns eventos importantes sendo realizados no país, 
como o Festival Sul-Americano da Cultura Árabe $(\mathrm{SACA})^{44}$, organizado pela Biblioteca e Centro de Pesquisa América do Sul-Países Árabes, que, em 2014, realizou sua quinta edição.

Também em 2014, foi lançado pela Câmara de Comércio Árabe-Brasileira em parceria com o Instituto da Cultura Árabe o concurso Os Árabes e a 25 de Março, que tem o propósito de estimular a produção de filmes de temática árabe, preservar e difundir a memória da comunidade árabe no Brasil e aprofundar o debate sobre essa cultura, que possui papel central na formação do processo identitário do país. ${ }^{45}$ Merece menção ainda, o fato de que na região da 25 de Março várias ruas tiveram seus nomes alterados e receberam denominação de pessoas da comunidade árabe no Brasil, reforçando a identidade da área. (KHOURI, 2013)

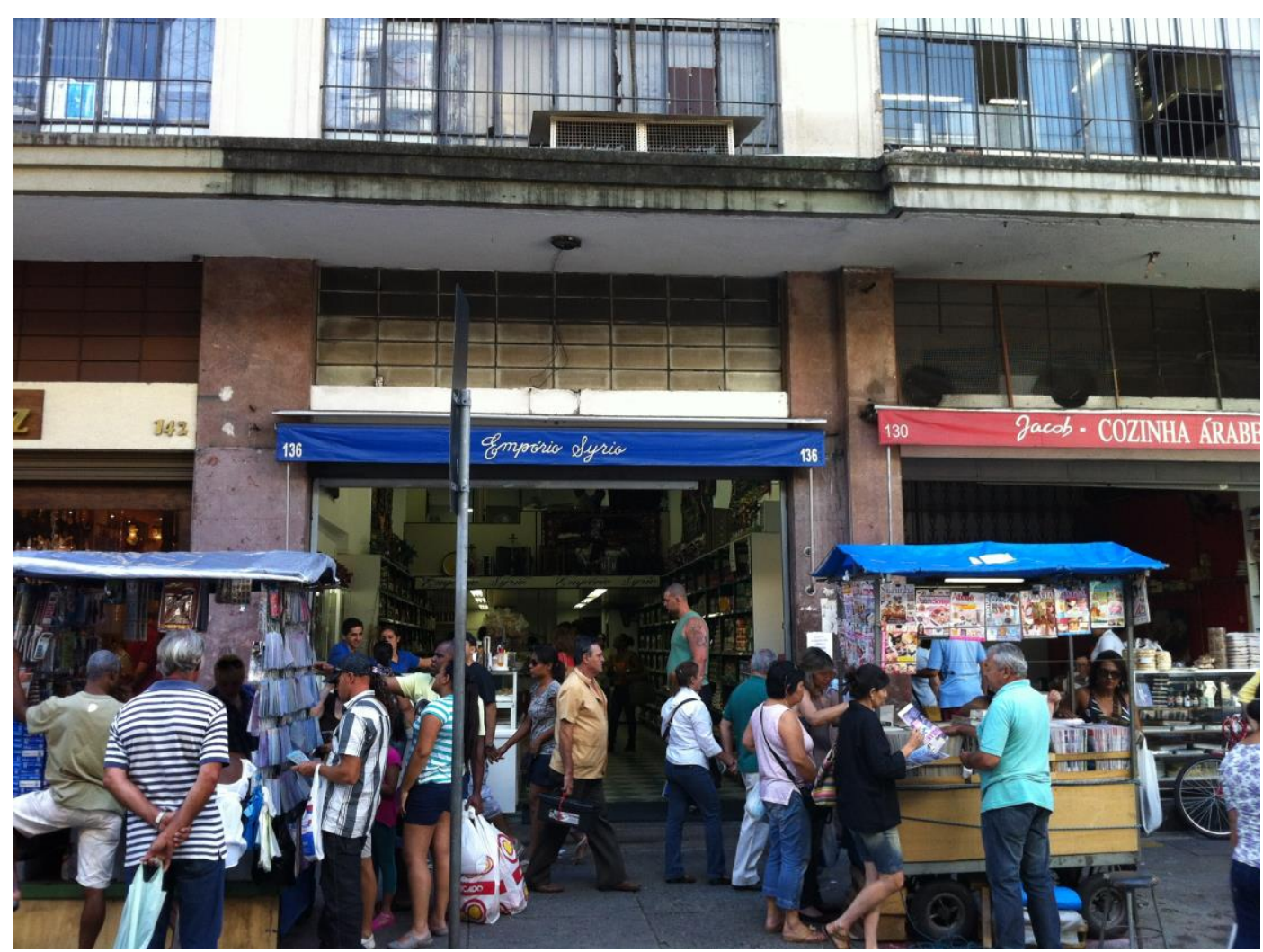

Figura 5 - Empório sírio e restaurante de comida árabe na Rua Comendador Abdo Schahin, adjacente à Rua 25 de Março em São Paulo (SP)

\footnotetext{
${ }^{44}$ Disponível em: http://festivaldaculturaarabe.wordpress.com/. Acesso em: set. 2014.

${ }^{45}$ Disponível em: http://www.curta25.com.br/. Acesso em: set. 2014.
} 
Logo após São Paulo, o estado de Minas Gerais foi o segundo a receber maior contingente de sírio-libaneses, seguido do Rio de Janeiro. E seguiu notória sua forte presença no comércio varejista também nesses estados. Também na Amazônia, a presença do imigrante árabe foi de fundamental importância, especialmente no período referente ao chamado "Ciclo da Borracha".

As profundas raízes árabes no Brasil também já foram objeto de estudos e artigos dentro e fora do país. Como exemplo, pode-se citar uma matéria publicada pelo The Washington Times em julho de 2005, cita uma entrevista com o presidente da Câmara de Comércio Árabe-Brasileira, Antonio Sarkis, que afirma haver no Brasil a maior população árabe fora do Oriente Médio, ultrapassando, entre descendentes e imigrantes, a cifra de 10 milhões de pessoas. ${ }^{46}$ Outros pesquisadores, como, por exemplo, Claude Hajjar (2014), afirmam que este número é ainda maior, chegando a 18 milhões, se considerados os imigrantes árabes e seus descendentes.

Como é sabido, o Brasil possui uma importante comunidade árabe formada em diversas levas migratórias desde o século XIX e que se intensificaram recentemente devido aos conflitos e instabilidade política no Oriente Médio, como a Guerra Civil Libanesa (1975-1990), o conflito Palestino-Israelense (desde 1948) e a violência decorrente da invasão Anglo-Americana do Iraque em 2003. Estimativas extra-oficiais apontam para cerca de 6 milhões de árabes e descendentes no Brasil. A comunidade árabe no Brasil tem um alto grau de integração na sociedade brasileira ao mesmo tempo que muitos dos seus membros mantêm uma identidade étnica ligada a instituições comunitárias (clubes, associações culturais ou instituições religiosas) e a laços transnacionais baseados em deslocamentos, relações de parentesco e imaginários sociais orientados

\footnotetext{
${ }^{46}$ Disponível em: http://p.washingtontimes.com/news/2005/jul/11/20050711-092503-1255r/?page=all. Acesso em: jan. 2014.
} 
para o "local de origem", real ou imaginário, no Oriente Médio. (PINTO $\&$ MONTENEGRO, 2011) ${ }^{47}$

Esse número, se tomado para toda a América Latina, seria ainda muito maior. Apesar da importância que possui a presença árabe nessa região, estudos realizados sobre o tema seguem sendo escassos (AKMIR, 2009). Os poucos trabalhos que existem se limitam, segundo levantamento feito pelo autor, a cobrir determinados países, salvo um estudo editado pela UNESCO em 1997, organizado por Raimundo Kabchi, analista político do Instituto de Estudios Diplomáticos Pedro Gual (IAEDPG), do Ministério de Relações Exteriores da Venezuela, e que abarca a presença das colônias árabes em 14 países latinoamericanos. Akmir também elenca um conjunto de causas e tramitações da emigração árabe para a América Latina que merecem ser citadas:

1. Causas socioeconômicas (no início do processo migratório, observava-se a decadência das tradicionais estruturas econômicas do império otomano do qual dependiam a Síria, Líbano e Palestina, países de procedência da maioria dos árabes na América Latina. Tal decadência foi uma oportunidade para que as potências europeias pudessem influenciar decisivamente no controle econômico e político do império otomano, sobretudo quando foi declarada a sua "falência" em 1878, diante da sua incapacidade de pagar a dívida externa que havia acumulado. Diante desse contexto, o governo turco implementou uma política austera, que tornou ainda mais aguda e precária a situação econômica das províncias árabes, tanto urbanas quanto rurais);

2. Causas religiosas (o aspecto religioso influenciou sobremaneira a migração árabe);

3. Causas culturais;

${ }^{47}$ Trabalho apresentado na $26^{\mathrm{a}}$ Reunião Brasileira de Antropologia, realizada entre os dias 01 e 04 de junho, 2011. Porto Seguro, Bahia, Brasil. Disponível em: http://www.abant.org.br/conteudo/ANAIS/CD_Virtual_26_RBA/foruns_de_pesquisa/trabalhos/FP\%2002/F P02\%20As\%20comunidades\%20mu\%C3\%A7ulmanas\%20na\%20Triplice\%20Fronteira....pdf. Acesso em: ago. 2014. 
4. Causas políticas: o começo da imigração árabe na América Latina coincide com as mudanças políticas observadas dentro do império otomano.

Interessante mencionar que o número de árabes no Brasil, durante o primeiro tercio do século XX, era muito superior quando comparado a outros países latinoamericanos. Por exemplo, em 1926, havia 162 mil árabes vivendo em solo brasileiro, ao passo que na Venezuela e na Colômbia havia pouco mais de três mil em cada país. Cabe observar que havia mais imigrantes oriundos desses países no Brasil do que na Argentina, que também recebeu uma quantidade significativa de árabes (64 mil em 1914). Consequentemente, é muito difícil avaliar o peso quantitativo das comunidades árabes nesses países, haja vista que essas comunidades são formadas atualmente por descendentes, já considerados cidadãos latino-americanos, sem qualquer vínculo jurídico com os países dos seus antepassados.

A falta de estatísticas fidedignas tanto em países de saída como de entrada, e de estudos estatísticos especializados, nos obriga a fazer uso de estimativas que nem sempre cumprem com o rigor científico desejado. (AKMIR, 2009, p. 21)

Em que pese a dificuldade em quantificar efetivamente essa presença pela via da migração, seja na América Latina, seja especificamente no Brasil, não raro os árabes são mencionados na literatura brasileira como elemento integrante da nossa sociedade. Muitas vezes citados como personagens centrais de narrativas fictícias ou de fundo histórico, ainda que algumas vezes sejam descritos na forma caricaturada - o fato é que importantes escritores incluíram sírios, libaneses e "turcos" em suas obras e essa presença também nas obras literárias brasileiras não poderia passar despercebida.

Se contemporâneos, tal Milton Hatoum, Alberto Mussa, Raduan Nassar ou Bernardo Carvalho, dentre outros, inauguraram a tematização do imigrante árabe na literatura nacional, Jorge Amado não fugiu à regra: não é tema novo em suas obras, e inúmeros trabalhos têm-no revelado. 
Convém, no entanto, esclarecer que no romance A descoberta da América pelos turcos o autor propõe ao leitor um novo olhar sobre a figura do migrante: afastando-se do estereótipo, ele retrata de maneira positiva até os estigmas mais comuns aos árabes como a avidez no comércio ou ainda a poligamia. Ele apresenta a cultura árabe como sendo um dos componentes do amalgama cultural que caracteriza a população brasileira. (GARCIA, 2014)

A professora de literatura portuguesa pela USP, Marlise Vaz Bridi, em artigo intitulado Entre o real e o cultural chama atenção para essa questão. Segundo ela, "a cultura árabe, independente de modismos recentes, tem presença marcante na ficção brasileira contemporânea". ${ }^{48}$ Dentre o conjunto de obras mencionadas pela autora, podemos citar: Lavoura Arcaica (1975) de Raduan Nassar, Relatos de um Certo Oriente (1990) e Dois Irmãos (2000) de Milton Hatoum, O Enigma de Qaf (2004) de Alberto Mussa, além dos escritores Leon Eliachar, Jorge Medauar, Jorge Tufik, Jorge Tanure, Salim Miguel, João Batista Sayeg, Júlio Cesar de Melo e Sousa (que, embora não fosse árabe, marcou a literatura brasileira ao adotar o pseudônimo de Malba Tahan, para publicar livros voltados, em sua maioria, para transmissão de ensinamentos matemáticos. Provavelmente a sua obra mais famosa seja O Homem que Calculava, escrito em 1938 e que já passou de sua $80^{a}$ edição).

Vale lembrar também do romance Noite Grande, de Permínio Asfora, escrito em 1944, publicado no ano seguinte e reeditado pela BibliASPA (2012). Uma obra que trata sobre as tragédias enlaçadas de dois povos: o palestino e o nordestino, e abarca a dolorosa convivência dos momentos mais dramáticos da existência do pai palestino aqueles que precederam a longa noite, a noite grande que cairia sobre sua terra e de seus ancestrais.

Villar (2008), que dedicou sua pesquisa de mestrado à presença árabe nas obras de Jorge Amado e Milton Hatoum, também chama atenção para o fato de que, Jorge

\footnotetext{
${ }^{48}$ Disponível em:

http://www.mackenzie.com.br/fileadmin/Pos_Graduacao/Doutorado/Letras/Publicacoes/Artigo_MarliseVazB ridi_Entre_o_real_e_o_cultural.pdf. Acesso em: set. 2014.
} 
Amado, ao privilegiar a presença árabe, em meio à sua construção identitária do Sul da Bahia:

inaugurou um caminho estético, marcado pela ausência de estranhamento e por uma perspectiva de mão dupla, que ora realça o agudo sentimento árabe de pertencimento à nossa terra, com a correspondente e efusiva aprovação das personagens brasileiras, o que só é possível graças ao apagamento das diferenças e ao realce das similaridades culturais entre nós e os árabes; ora o caminho em que, numa estratégia claramente mais complementar, tanto o árabe quanto o brasileiro reconstroem, solidariamente, o espaço nacional, como se verifica, hoje, em Milton Hatoum. (idem, p.47)

Villar também recorda a produção literária de Carlos Drummond de Andrade, que tematizou o mundo árabe, dentre outros contextos, em seu poema Turcos, do livro Boitempo (1968):

OS TURCOS nasceram para vender bugigangas coloridas em canastras ambulantes.

Têm bigodes pontudos, caras de couro curtido, braços tatuados de estrelas.

Se abrem a canastra, quem resiste ao impulso de compra?

É barato! Barato! Compra logo!

Paga depois! Mas compra!

A cachaça, a geléia, o trescalante fumo de rolo: para cada um

o seu prazer. Os turcos jogam cartas com alarido. A língua cifrada cria um mundo problema, em nosso mundo como um punhal cravado.

Entendê-los, quem pode? 
A turca, ei-la que atende

A fregueses sem pressa,

Dá de mamar, purinha, a seu turquinho

O seio mais que farto.

Jacó, talvez poeta

Sem verso e sem saber que existe verso

Altas horas exila-se

No alto da cidade, a detectar

No escuro céu por trás das serras

Incorpóreas Turquias. E se algum

Passante inesperado chega perto

Jacó não o conhece. Não é o mesmo

Jacó de todo dia em sua venda.

É o ser não mercantil, um elemento

Da noite perquirinte, sem fronteiras

Os turcos,

meu professor corrige: Os turcos

não são turcos. São sírios oprimidos

pelos turcos cruéis. Mas Jorge Turco

aí está respondendo pelo nome,

e turcos todos são, nesse retrato

tirado para sempre.... Ou são mineiros

de tanto conviver, vender, trocar e ser

em Minas: a balança

no balcão, e na canastra aberta

o espelho, o perfume, o bracelete, a seda,

a visão de Paris por uns poucos mil-réis?

(DRUMMOND apud VILAR, 2008, p. 48) 


\subsection{A presença árabe no Brasil pela via da herança ibérica}

As primeiras incursões dos árabes na Europa se deram no Califado de Muawiya, primeiro Califa Omíada, sendo que as tentativas de ocupação de territórios começaram por volta de 710 na Península Ibérica, e 740, na ilha da Sicília e na Península Itálica. [...] Foi na Espanha que os árabes obtiveram suas maiores e mais duradouras conquistas na Europa. [...] O processo de arabização na Espanha foi tão intenso que, no século IX, o Arcebispo de Sevilha achou necessário traduzir a bíblia para o árabe, que seria usada pelos cristãos espanhóis, tal era a difusão da língua árabe na Península Ibérica. A palavra Moçárabe, que vem do árabe Mustarib (arabizante), era utilizada para designar os cristãos e judeus na Espanha que falavam árabe. (BELTRÃO, 2000, p.46, p. 48-50)

A expressividade da imigração árabe para o Brasil pode ser vislumbrada por

meio das palavras do professor honorário do Instituto de Estudos Avançados da Universidade de São Paulo (USP), falecido em março de 2012, o geógrafo Aziz Nacib Ab'Saber: "no conjunto atual da população brasileira, existe um representante do mundo árabe para cada 150 brasileiros, e mais dois descendentes para igual número de nacionais. (FUNDAG, 2000)

Entretanto, mergulhando um pouco mais a fundo na possível influência dos povos árabes na cultura brasileira, percebe-se que falar sobre essa presença é ir muito além de censos e registros de fluxo migratório.

O ponto de partida de nossos vínculos é anterior ao estabelecimento de relações diplomáticas entre Brasil e Egito, ou às viagens do imperador Dom Pedro II ao Líbano. Suas origens situam-se mesmo antes do fluxo migratório de sírios e libaneses desde as últimas décadas do século XIX. $\mathrm{Na}$ verdade, a mentalidade, a arte, a técnica e a cultura material árabes 
estão presentes desde a gênese ibérica do Brasil colônia. (CHOHFI, 2000) ${ }^{49}$

E ainda:

Para o Brasil é provável que tenham vindo, entre os primeiros povoadores, numerosos indivíduos de origem moura e moçárabes, junto com cristãos-novos e portugueses velhos. (FREYRE, 2003, p. 256)

No período das grandes navegações, o Novo Mundo assimilou parte da cultura árabe que havia sido trazida pelos espanhóis e portugueses, e hoje a sua influência é visível em traços do cotidiano. O café, por exemplo, foi introduzido pelos árabes na Europa, assim como o cultivo do arroz, alimento tipicamente chinês, mas que conquistou o resto do mundo pelos árabes. Igualmente na arquitetura, é possível encontrar traços da cultura árabe trazida pelos ibéricos no uso dos azulejos decorativos, no chafariz, nos pátios floridos e nos detalhes em arabescos.

O Nordeste e os Gerais do Estado de Minas convivem com o efeito residual de oito séculos de dominação árabe na Península Ibérica, desde a Baixa Idade Média até a boca do Renascimento. Ou seja, enquanto os bisavós do Sr. Mazaropi eram educados pelos bárbaros cristãos, em todo o Velho Continente, a Península Ibérica (Portugal e Espanha) recebia uma sofisticada educação, com a cultura moçárabe. É que o povo árabe, naquele momento, era a sociedade mais culta do planeta. E encontramos esses oito séculos de cultura no sertanejo analfabeto. Seus antepassados chegaram ao Brasil nos séculos 16 e 17. No Nordeste e nos Gerais, empobreceram, tornaram-se analfabetos, mas tanto amavam a herança moçárabe dos avós que começaram a dançar cultura, cantar cultura, falar cultura. E a ler conceitos metafísicos nos eventos do dia-a-dia; a fazer

49 Conforme ressaltado no documento base do Seminário Relações entre o Brasil e o mundo árabe organizado pela Fundação Alexandre Gusmão (FUNDAG) em 2000. 
pentimento, sobrepondo à dura paisagem nordestina chaves de conhecimento esotérico; e uma humorada Weltanschauung que sobrevive à miséria, estabelecendo eixos filosóficos na sintaxe de uma língua têxtil. ${ }^{50}$ (Tom Zé, músico brasileiro)

Estudos sobre assuntos os mais variados, tais como a história de instrumentos musicais ou a origem de iguarias que fazem parte do cardápio do povo brasileiro revelam algumas curiosidades relacionadas a essa influência cultural. Entre elas, por exemplo, está a introdução de um instrumento de percussão africano de origem árabe ao samba, conhecido como adufe ${ }^{51}$, um instrumento folclórico membranofone, de percussão, também chamado adufo. De origem moura, trata-se de uma espécie de pandeiro quadrado, sem os discos de metal, oco e de madeira leve, que se toca com os dedos, sustentado pelos polegares, e que aparece em festas tais como Folia-de-Reis, Folia-do-Divino, Congadas, entre outras.

${ }^{50}$ Disponível em: http://www.tomze.com.br/index.php?option=com_content\&view=article\&id=118\%3Aartigo-e-festivo-naoe-serioq-diz-tom-ze\&catid=8\%3Aimprensa\&Itemid=18. Acesso em: jul. 2014.

${ }^{51}$ João Baptista de Medeiros Vargens, professor de árabe do Departamento de Letras Orientais e Eslavas da Universidade Federal do Rio de Janeiro (UFRJ) e autor, ao lado de Carlos Monte, do livro A Velha Guarda da Portela (2001) afirma que nas batucadas nos morros do centro do Rio de Janeiro, nos primeiros anos do século 20, o samba foi fortemente influenciado por este instrumento semelhante ao pandeiro, só que em formato hexagonal e sem platinelas, tendo-o ajudado a chegar à batida rítmica que hoje o caracteriza. 


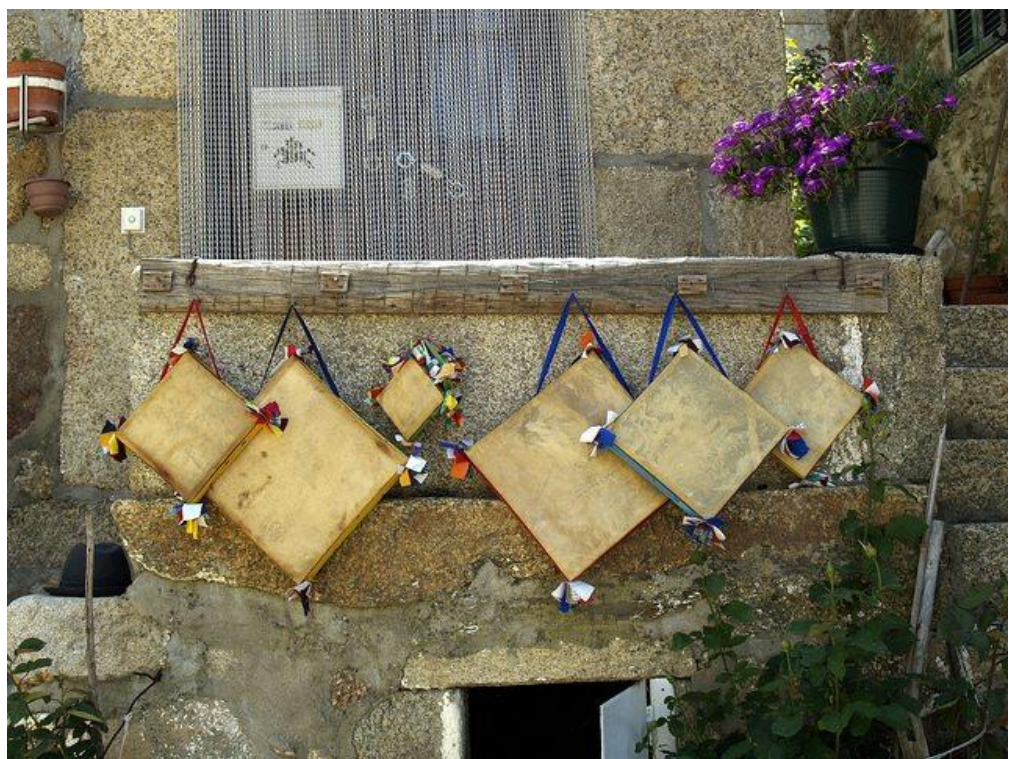

Figura 6 - Instrumento musical de origem moura conhecido como Adufe

A influência nos idiomas português e espanhol pode ser notada em uma infinidade de palavras, tais como açougue, tambor, arroba, cenoura etc. Cabe destacar que a grande maioria das palavras iniciadas por "al”, artigo definido na gramática do idioma árabe foi sendo incorporado por nossos antepassados. Como bem apontou Antônio Houaiss:

$\mathrm{Na}$ verdade, é Idade Média para o ocidental, mas, para o árabe, é o período de esplendor. Essa diferença explica, então, este fenômeno muito singular: num total de três mil a três mil e duzentas palavras do português primitivo, há, no mínimo, oitocentas palavras de origem árabe. Numa estatística verbal, contemporânea de então, é impressionante o acervo de palavras árabes que existiam vivas no português. Representam algo em torno de $25 \%$ do vocabulário da língua portuguesa primitiva. E essa estatística toma em conta, também, os vocábulos então recém-derivados. (HOUAISS, 1986).

Também Abreu \& Aguilera (2010, p. 12) oferecem exemplos "facilmente observáveis" no vocabulário de origem árabe. 
Alguns vocábulos possuem x- inicial, como é o caso de: xá, xadrez, xairel, xaque, xará, xarque, xeique, xerife, xarifa, xaroco, xarofa, xarope, xaveco, xeique, xiita etc, e influenciaram os representantes de numerosos termos latinos com ex-, como: enxame, enxuto, enxada, enxó, enxugar, enxúndia e enxofre. Outros vocábulos iniciam com enx-, como os seguintes: enxaqueca, enxadrez, enxarope, enxávena, enxeco, enxoval, enxovia etc. Um grupo numeroso de vocábulos se caracteriza pela terminação, entre essas estão os termos que terminam com i-tônico: aleli, alfarqui, alizari, arabi, bafari, carmesi, garabi, haji, huri, javali, maçari, muçurumi, rafadi etc. Em muitos casos, o sufixo i- é transformado em il: adail, aguazil, alcil, alvazil, anafil, anil, arrabil, candil, cordovil, granadil, manchil, maravedil, marroquil etc. E há casos em que o sufixo i-muda para im: alabardim, alecrim, alfenim, alfolim, alfonsim, anexim, benjoim, borzeguim, cansim, carmesim, celamim, cetim, gergelim, haquim, jasmim, marfim, mirabolim, muslim, muezim, talim etc. Além desses, há casos de palavras que terminam em sílabas como afe, -afre, -efe ou -aque, que não são empregadas em final de vocábulos latinos. (idem, p. 12)

Truzzi (2007), em artigo sobre a presença árabe na América do Sul, lembra que ela já era realidade neste continente muito antes da imigração inaugurada ao final do século XIX. Segundo ele e outros pesquisadores, no Brasil, ela já se insinuava por meio de vínculos religiosos, ocasionada pelos africanos muçulmanos malês na Bahia escrava desde o século XVIII ${ }^{52}$ (RIBEIRO, 2011). E ainda, antes disso, também pode ser identificada tal influência à época do início da colonização portuguesa tanto na língua, quanto na música, culinária, decoração e vestuário, para citar alguns exemplos.

Seja por sua profunda influência em Portugal, seja pela forte imigração no último século, a cultura árabe tem presença garantida na história e na

\footnotetext{
${ }^{52}$ A palavra "malê" vem do ioruba "imale". Era forma de se referir aos os negros mulçumanos que resistiram e reagiram à imposição do catolicismo, mantendo sua crença e cultura na primeira metade do século XIX. Estes muçulmanos eram bastante instruídos e chegaram a organizar inúmeros levantes, sendo que a "Revolta dos Malês" é a mais conhecida delas.
} 
sociedade brasileiras. Junto com os colonizadores, no século XVI, desembarcaram heranças de sua língua, música, culinária, arquitetura e decoração, técnicas agrícolas e de irrigação, farmacologia e medicina. É que os árabes dominaram por quase oito séculos a Península Ibérica. Significativamente, Granada, seu último reduto em solo europeu, foi conquistada pelos cristãos em 1492, mesmo ano em que Colombo chegava à América. (TRUZZI, 2009)

Em seus argumentos, Truzzi inevitavelmente remete o leitor a Gilberto Freyre, que, em 1933 ao publicar Casa Grande \& Senzala, sinalizou para a importância do contato entre os portugueses e mouros durante a Idade Média, o que teria sido fundamental para que os lusitanos realizassem com sucesso a empreitada das grandes navegações.

A dualidade na cultura e no caráter dos portugueses acentuou-se sob o domínio mouro, e uma vez vencido, o povo africano persiste sua influência através de uma série de efeitos da ação e do trabalho dos escravos sobre os senhores. A escravidão a que foram submetidos os mouros e até moçárabes, após a vitória cristã, foi o meio pelo qual se exercem sobre o português decisiva influência, não só particular do mouro, do maometano, do africano, mas geral, do escravo. [...] Sem a experiência moura, o colonizador teria provavelmente fracassado nessa tarefa formidável. (FREYRE, 2003, p. 285)

Em uma direção semelhante, ao publicar em 1936, Sobrados e Mucambos, Freyre deu sequência ao desenvolvimento de ideias apresentadas anteriormente, sobre o embate entre o Ocidente e o Oriente, no Brasil, durante o século XIX, mantendo sempre o argumento de que a cultura brasileira teria sido gerada a partir de uma matriz oriental de valores, hábitos e conceitos sobre o mundo. Em outras palavras, em sua obra é possível identificar um pensamento acerca de uma orientalidade e de um amouriscamento do Brasil.

Uma importante população muçulmana livre permaneceu, sobretudo, no sul lusitano reconquistado pelos senhores cristãos. Nas cidades, ela 
habitava as mourarias, como os judeus viviam nas judiarias. Mouros capturados no Mediterrâneo e trazidos de outras regiões da Península Ibérica trabalhavam igualmente como cativos em Portugal. O domínio da escravização do muçulmano levou a que, na língua portuguesa, mouro se tornasse sinônimo de cativo. (MAESTRI, 2006, p. 102)

A obra de Freyre permite reunir um conjunto de informações sobre como esta presença moura persistiu na vida íntima do brasileiro desde os tempos coloniais até os dias de hoje, a partir de sua permanência na Península Ibérica.

Através desse elemento moçárabe é que tantos traços da cultura moura e mourisca se transmitiram ao Brasil. Traços de cultura moral e material. [...] Diversos outros valores materiais, absorvidos de cultura moura ou árabe pelos portugueses, transmitiram-se ao Brasil: a arte do azulejo que tanto relevo tomou em nossas igrejas, conventos, residências, banheiros, bicas e chafarizes; a telha mourisca; a janela quadriculada ou xadrez; a gelosia $^{53}$; o abalcoado; as paredes grossas. Também o conhecimento de vários quitutes e processos culinários; certo gosto pelas comidas oleosas, gordas, ricas em açúcar. O cuscuz, hoje tão brasileiro, é de origem africana. (FREYRE, 2003, p. 298)

De fato, esses elementos se manifestaram com frequência nas fotografias recebidas no âmbito do projeto Presença Árabe no Brasil em Imagens, sendo que imagens de comidas e hábitos alimentares foram os que mais receberam atenção por parte dos colaboradores que participaram do estudo.

De forma semelhante, Câmara Cascudo (2001, p.15), também identificou traços da presença árabe na cultura brasileira. E, assim como Gilberto Freyre, optou pelo termo mouro ao invés de árabe, pois, segundo ele, sua intenção era falar sobre aquele que

\footnotetext{
${ }^{53}$ Grade de fasquias de madeira que se coloca no vão de janelas ou portas, para proteger da luz e do calor, e através da qual se pode ver sem ser visto. "Gelosia". In Dicionário Priberam da Língua Portuguesa. Disponível em: http://www.priberam.pt/dlpo/gelosia. Acesso em: 25 ago. 2014.
} 
viajou para o Brasil na memória do colonizador e que aqui ficou. Segundo ele, a opção pelo uso da palavra mouro, ao invés de árabe ou sarraceno, deve-se ao fato de que este era mais constante na Península Ibérica:

[...] lembrando os berberes, mouros históricos, reinando na Espanha, vivos na recordação lusitana, Ifriqiya e Maghreb. No Brasil, árabe tomouse genérico nas últimas décadas do século XIX com a emigração da Síria e do Líbano, nominal popularíssimo, inclusive com o falso sinônimo de turco, vendedor ambulante que seria também o regatão, familiar nos rios amazônicos. O sarraceno não se aclimataria no linguajar nacional. (CASCUDO, 2001, p. 12)

Nessa direção, o folclorista recorreu aos costumes populares e à literatura para localizar traços da presença árabe na cultura brasileira. Segundo o próprio autor, "mais uma vez os meus Mouros e Judeus procuram olhos contemporâneos para avivar-lhes as distantes reminiscências imemoriais, inconscientes, vivas, atrás da cortina do passado". (CASCUDO, 2001, p. 9)

Argumentava que o mouro fora expulso do Algarve duzentos e cinquenta anos antes da vinda portuguesa para o Brasil. E, na Espanha, a saída dos muçulmanos levou ainda mais tempo, tendo sido necessário aguardar até 1492 para que o reino de Granada se tornasse castelhano, mesmo ano em que Cristóvão Colombo daria início a sua jornada em direção ao Novo Mundo.

Tema que se faz presente em praticamente toda a obra folclóricoetnográfica e histórica de Câmara Cascudo, a alimentação popular, em sua "normalidade" ou "dias festivos", traduz-se em matéria quase obrigatória do seu interesse investigativo. Além da constância no conjunto dos estudos cascudianos, ganham relevo suas obras devotadas exclusivamente ao tema, como A cozinha africana no Brasil. (AVIGNAC \& OLIVEIRA, 2010)

Dentre os aspectos culturais que podem ser atribuídos aos mouros, está, entre outros, o de beber depois de comer (e não durante a refeição), sentar-se sobre as pernas 
dobradas (segundo ele, de cócoras era influência indígena) etc. Para Cascudo, a mulher botando pano na cabeça é costume mouro, assim como o uso de turbante em penteados femininos no Brasil. Em seu argumento, graças à longa convivência forjada por moçárabes, mudéjares e mestiços, tanto a língua espanhola quanto a portuguesa são fortemente tributárias do árabe.

Mouros livres viviam em Portugal, após a Reconquista, e judeus migraram para Portugal, desde a Espanha, após 1492. Em Portugal, mouros e judeus foram obrigados a converter-se, originando a população de cristãos-novos. Mouros cativos seguiram sendo introduzidos em Portugal, sendo superados pelos negro-africanos, em fins do século 15. Chamava-se de "mourisco" o mouro convertido livre, liberto e escravizado. A historiografia portuguesa pouco atenção deu às minorias históricas. O artigo comenta o importante livro de Isabel Braga, Mouriscos e cristãos no Portugal quinhentista: duas culturas e duas concepções religiosas em choque, que traça importante perfil da população mourisca, a partir da documentação da Inquisição. Analisa-se também a narrativa histórica da autora como registro das razões que ensejaram o silêncio historiográfico relativo sobre as comunidades lusojudaicas, luso-islâmicas e luso-africanas. (MAESTRI, Mario, 2006, p. 101)

Em estudo acerca da luta pela etnicidade no Brasil, o historiador americano Jeffrey Lesser apontou Gilberto Freyre e Luís da Câmara Cascudo como pensadores que estiveram entre o grupo de intelectuais os quais, no século $\mathrm{XX}$, voltaram seus olhos para Portugal em busca de autocompreensão. Ainda que esta busca acerca de uma identidade nacional não tenha sido tarefa exclusiva de ambos os pensadores, Freyre e Cascudo estão entre os que mais contribuíram para a questão da presença árabe no Brasil ao procurarem traços da "presença moura em suas próprias identidades lusificadas". (LESSER, 2001)

Ao olharem para Portugal com o intuito de compreender o Brasil do século $\mathrm{XX}$, tais autores acabaram por reconhecer e apontar influências mais distantes, quais sejam, aquelas impregnadas na Península Ibérica ao longo de quase oito séculos de 
presença muçulmana na região. Ambos identificaram o alcance dos chamados mouros também na cultura brasileira, influência esta pouco explorada até os dias atuais.

Muito comum na tradição da ensaística social brasileira, especialmente aquela dedicada à busca e compreensão das chamadas 'raízes' do Brasil, tem sido o relativo silêncio em torno da forte presença moura em toda Península Ibérica (século VIII ao XV) e sua enorme importância histórica para o fazimento do povo português. Mesmo aqueles que parecem ter escapado à regra, como Gilberto Freyre e Câmara Cascudo, por exemplo, o fizeram sem a força de uma necessária ênfase fenomenológica, cuja análise pudesse nos oferecer um pouco mais do que o famoso borrão antropológico no perfil da lusitanidade (o conhecido argumento da 'plasticidade' portuguesa) ou ainda a coleção - decerto amiúde curiosa de pequenas notas 'folclóricas' no rodapé de nossa história. Mais sintomático ainda é o emprego, em tantos outros autores, do próprio termo 'moçárabe' na tentativa de dar relevo justamente ao 'cristão arabizado', e não, como talvez fosse mais apropriado, o contrário (ao longo deste ensaio buscarei justificar melhor essa tese). Não obstante a óbvia herança da língua (Bilac: 'amo-te, assim, desconhecida e obscura'), o que permaneceu mesmo, no fundo, foi sempre uma imagem demasiadamente romanizada do colonizador português, algo de que não escapou, inclusive, toda a sabida perspicácia de um Darcy Ribeiro. (FORTES, 2013, p. 4)

Cabe também citar o catalão Luis Soler, autor do livro Origens árabes no folclore do sertão brasileiro (SOLER, 1995), músico que conviveu com Ariano Suassuna além de ter sido professor do artista pernambucano Antônio Carlos Nóbrega na época do Quinteto Armorial. Segundo ele, as modalidades do repente nordestino são modalidades de desafio árabes. Soler explica que os árabes introduziram a rima no mundo ocidental, pois a poesia latina contava apenas com a métrica.

Dentre outras influências musicais assimiladas em Portugal através do estreito convívio que cristãos e mouros mantiveram por séculos, e que chegaram até a cultura brasileira é possível destacar o martelo agalopado, o galope à beira-mar, a sextilha, o 
quadrão e o martelo alagoano, como aponta o músico, pesquisador e professor da Escola de Comunicações e Artes da USP, Ivan Vilela.

Quando os árabes chegaram à Península Ibérica, no ano de 722, os instrumentos de cordas dedilhadas presentes na Península eram as harpas celtas e as cítaras greco-romanas. O oud, também conhecido por alaúde árabe, foi o primeiro instrumento de cordas dedilhadas com braço onde as notas podiam ser modificadas, que chegou à Europa. Curioso observarmos que a viola mantém como característica básica de seu velho ancestral as cinco ordens de cordas. O alaúde árabe tem cinco pares uníssonos e às vezes um bordão só é colocado abaixo das cordas mais agudas para facilitar as respostas entre graves e agudos na melodia. Muitas vezes este bordão é utilizado como um pedal. Normalmente este bordão solo tem a mesma nota que os bordões em dupla. Já a viola, independente do número de cordas que venha a possuir, de cinco a quinze, sempre mantém a ideia das cinco ordens, podendo ser estas simples, duplas, triplas ou até mistas. A partir do enlace cultural de mouros, cristãos e judeus sefarditas inúmeros instrumentos foram gestados. A fusão que se processou neste período na Península Ibérica foi tal que por volta do século XIII, surgiu a guitarra latina. (VILELA, 20082009). ${ }^{54}$

Vilela (2008-2009) também compartilha da tese de Soler, mencionado anteriormente, para quem comumente o "dominador" tende a assimilar mais a cultura do "dominado" que o contrário, pois estes últimos costumam resistir em todas as instâncias à invasão - a qual, além de militar, é também cultural. Nesse sentido, os portugueses, que, na Europa, estão entre os primeiros povos a terem configurado um reino próprio por meio da reconquista de territórios invadidos pelos muçulmanos, passaram a se estabelecer como

54 VILELA, Ivan. A Viola. Ensaio elaborado especialmente para o projeto Músicos do Brasil: Uma Enciclopédia, patrocinado pela Petrobras através da Lei Rouanet. 2008-2009. Disponível em: http://www.ivanvilela.com.br/pesquisador/ivanvilela-aviola.pdf. Acesso em: jan. 2014. 
dominadores, enquanto que os árabes que naquela região permaneceram, passaram a ser os dominados.

Importante ressaltar que em seu livro, Soler recorre muito mais a referências bibliográficas espanholas do que brasileiras para tratar desse assunto. Talvez porque, de fato, o tema da presença árabe tenha sido bem menos debatido no Brasil do que na Espanha. Em seu epílogo, Soler justifica a carência de material sobre a presença árabe no Brasil:

[...] Não é de estranhar-se que o peso desta influência tenha deixado de ser avaliado com justiça, habitualmente: os árabes, como indivíduos, representam um elemento irrelevante na colonização do sertão. A história brasileira não os registra aqui. E na hora em que a colonização do Brasil foi iniciada, a história da Península Ibérica era escrita pelo povo que acabava de desterrá-los, ou dizimava ou, no melhor dos casos procurava ignorá-los. Mas 800 anos de domínio político, de caldeamento racial e, sobretudo, de liderança cultural não se apagam de uma hora para outra. (SOLER, 1995, p. 113)

No entanto, dentre os pouquíssimos brasileiros que constam em sua bibliografia, estão, inevitavelmente, Gilberto Freyre e Câmara Cascudo, mas também se encontram Mário de Andrade e Sérgio Buarque de Hollanda, o primeiro com contribuições pontuais sobre a música do Brasil e o segundo com aportes na história da civilização brasileira.

A fim de completar as alusões às contribuições de Gilberto Freyre e Câmara Cascudo nos estudos sobre a presença árabe no Brasil, importante mencionar, ainda, duas últimas referências. Uma delas é a do poeta e crítico literário Manoelito Ornellas, o qual publicou, em 1948, o livro Gaúchos e Beduínos: a origem étnica e a formação social do Rio Grande do Sul. De forma semelhante ao que escreveu Gilberto Freyre em Casa Grande \& Senzala, o argumento do autor está no fato de que, tanto portugueses quanto espanhóis, antes de povoarem a América, haviam sido fortemente influenciados pelos árabes, berberes e beduínos. E, finalmente, propõe que as raízes dos atuais habitantes da Região Sul se encontram na África do Norte. 


\title{
CAPÍTULO 4 \\ DESCRIÇÃO DOS RESULTADOS: A MANIFESTAÇÃO DAS DIFERENTES PRESENÇAS ÁRABES NO BRASIL E O FENÔMENO DA ALIMENTAÇÃO
}

\begin{abstract}
Este capítulo consiste na apresentação dos resultados deste trabalho de tese de doutorado no departamento de Sociologia da Universidade de Brasília entre 2010 e primeiro semestre de 2014. Em virtude de este estudo ter contado com distintas técnicas de levantamentos de dados, o conteúdo ora apresentado será dividido em três grandes blocos, a saber:
\end{abstract}

1. O ponto de partida: a descrição da pesquisa exploratória, realizada no início do doutorado, no âmbito do projeto Presença Árabe no Brasil em Imagens;

2. A etapa de visitas de campo e entrevistas, que também contou com a participação de pessoas residentes fora de Brasília por meio do preenchimento de questionários respondidos e entrevistas realizadas na modalidade "mediada";

3. O detalhamento da observação participante virtual, no âmbito da página Presença Árabe no Brasil criada em uma rede social.

\subsection{O ponto de partida: a pesquisa exploratória}

A primeira etapa da pesquisa teve caráter exploratório, e ocorreu em um momento em que, ainda em processo de leitura e levantamento de material bibliográfico, realizou-se um considerável esforço para captar de forma espontânea que associações mentais costumam ser feitas por parte das pessoas ao falarmos sobre os árabes no Brasil.

A opção por trabalhar com fotografias e associação de ideias se deu após consulta a referências bibliográficas na área de sociologia visual e psicologia social. Os parágrafos a seguir têm o intuito de contextualizar o assunto, cabendo ainda mencionar que existe extensa bibliografia sobre o uso de fotografias em estudos conduzidos por sociólogos e antropólogos em todo o mundo, e que o assunto tem despertado cada vez mais interesse nas Ciências Sociais. 
Em 1942, Bateson e Mead lançaram o livro intitulado Balinese Character: A photographic Analysis (GODOLPHIM, 1995). Essa obra inaugurou uma nova etapa na Antropologia, permitindo empregar a fotografia, não apenas como ilustração do ambiente e dos sujeitos envolvidos nas pesquisas de campo, mas como instrumento de análise, tendo início a chamada Antropologia Visual.

Outros acadêmicos ligados às Ciências Sociais e Humanas também se debruçaram sobre a fotografia, ainda que tenham dado ênfases e importância diferentes a esse recurso de análise das sociedades. Porém, foi Roland Barthes quem mais se destacou enquanto precursor do uso e análise da imagem fotográfica por meio do método estruturalista, pioneiro no estudo da Semiologia. Barthes, ao falar sobre a fotografia de imprensa, argumentava que ela é uma mensagem. Segundo ele, “o conjunto desta mensagem é constituído por uma fonte emissora, um canal de transmissão e um meio receptor." (BARTHES in LIMA, 1969)

Recentemente, a fotografia parece estar ganhando cada vez mais espaço entre cientistas sociais. Howard Becker, em Falando de Sociedade (2010), dedica um capítulo inteiro para tratar deste recurso. Becker define três tipos de fotografia: a sociologia visual, a fotografia documental e o fotojornalismo, argumentando que os três assemelham-se a todas as outras maneiras de relatar o que sabemos ou pensamos ter descoberto sobre as sociedades em que vivemos. Para ele, "como todos os objetos culturais, as fotografias ganham sentido a partir de seu contexto", ou seja, o contexto dá significado a imagens.

Importante mencionar, ainda, o sociólogo José de Souza Martins e seu livro Sociologia da Fotografia e da Imagem (2011), onde o autor mostra como este campo da ciência pode encontrar nesses recursos indícios de relações sociais, de mentalidades, de formas de consciência social, maneiras de ver o mundo e compreendê-lo. Acrescenta-se ainda que Martins (2011, p. 36) chama a atenção para o fato de que a Fenomenologia, mesmo sem apoiar-se no recurso da fotografia e sem que seus principais teóricos demonstrassem interesse por ela, desponta como um campo possível para desenvolver estudos nessa linha. Segundo ele, a reflexão sociológica sobre a fotografia pode contribuir significativamente para desvendar aspectos do imaginário social e das mediações nas relações sociais que de outro modo seriam encarados sociologicamente com maior déficit de informação. Se a fotografia "nada acrescenta à precisão da observação sociológica, 
muito acrescenta à indagação sociológica na medida em que a câmera e a lente permitem ver o que por outros meios não pode ser visto".

Os traços delineadores da investigação aqui apresentada começaram a ser concebidos em 2010, momento em que a autora se deparou com uma questão que se manteve presente ao longo de toda a pesquisa, ainda que a indagação não tenha se convertido em objetivo principal:

Como as distintas presenças árabes no Brasil são notadas na vida social e que tipo de impacto é gerado a partir desta percepção?

Inicialmente, e fortemente influenciada pela formulação teórica das representações sociais concebida pelo psicólogo social Serge Moscovici e aprofundada com apoio de Denise Jodelet, ambos representantes máximos dessa linha de estudos que se originou na França há cerca de quatro décadas, acreditou-se que esta indagação seria um dos pontos centrais da pesquisa. E com base nessa perspectiva, deu-se início à etapa inicial de levantamento de dados primários, cujos resultados acabaram sendo determinantes para que a pesquisa ganhasse um novo direcionamento, com enfoque sobre a relação entre memória, identidade e alimentação, distanciando-se parcialmente dessa questão inicial.

Importante, entretanto, acrescentar que o tema da alimentação despontou ainda nessa etapa da pesquisa como importante elemento a ser investigado, colaborando, consequentemente, para que fosse dada ênfase nesse recorte no levantamento de dados realizado. No entanto, essa etapa da pesquisa foi muito importante para conhecer o imaginário das pessoas que se voluntariaram a participar do projeto, como elas viam e representavam as diferentes presenças árabes em nossa cultura.

O projeto foi concebido por meio da criação de um endereço eletrônico (www.presencaarabe.com), o qual contou com a criação de um banco de imagens, montado a partir da colaboração de todas as pessoas que se interessaram e dispuseram a participar por meio do envio de fotos que, na opinião de cada um/a, representassem exemplos da presença árabe na cultura brasileira. As imagens começaram a ser enviadas a partir de 01 de novembro de 2011, após publicação, por mim sugerida, de uma matéria na página da Agência de Notícias Brasil-Árabe, cuja imagem capturada feita no dia da sua divulgação 
pode ser vista no Anexo 4. Este estudo exploratório teve duração de um ano e foi intitulado "Presença Árabe no Brasil em Imagens".

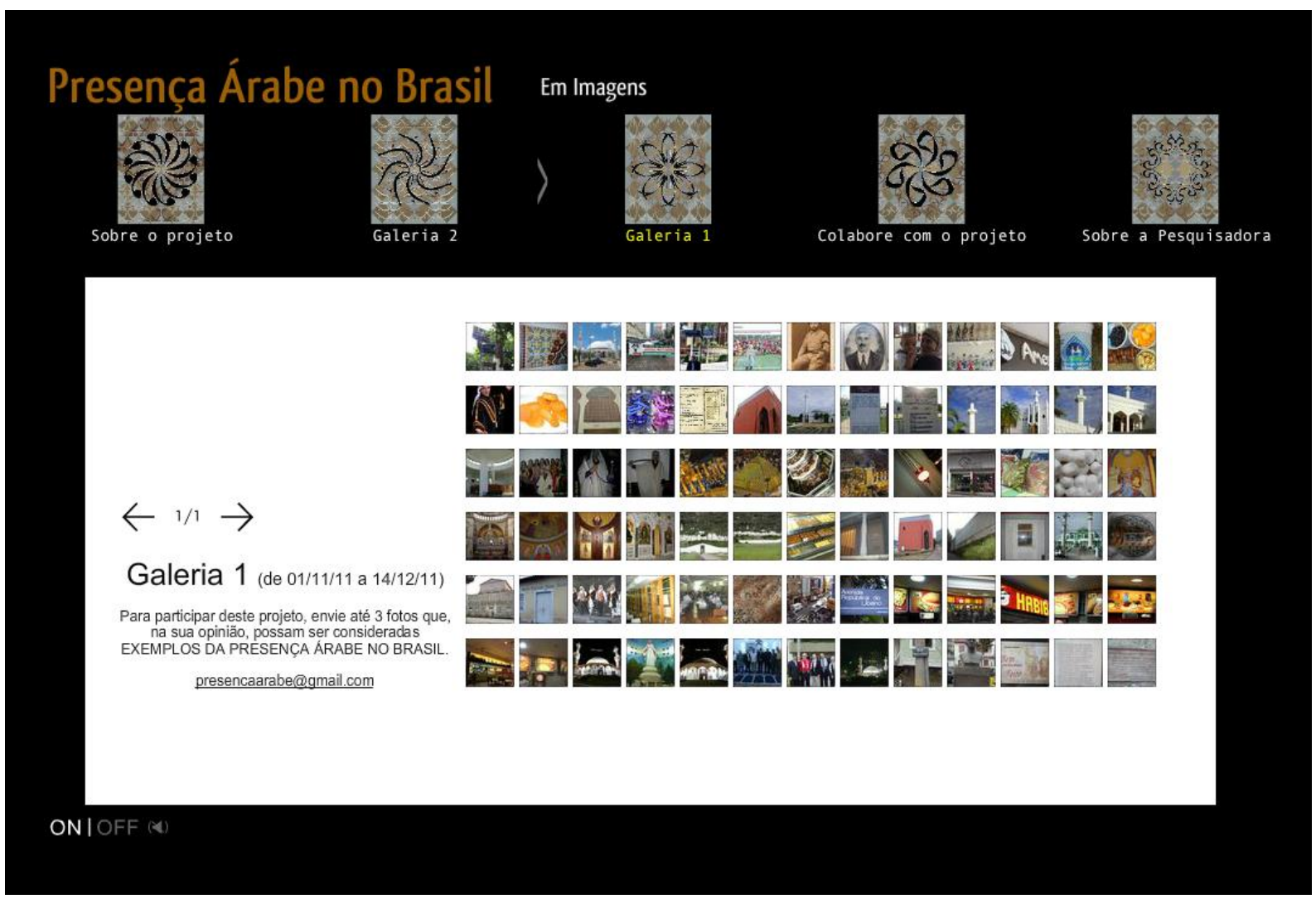

Figura 7 - Imagem da galeria de fotos do site Presença Árabe no Brasil em Imagens

No intervalo de doze meses, o site reuniu 149 fotos enviadas por 43 voluntários $^{55}$. Cada mensagem enviada por e-mail com as imagens em anexo continha informações sobre o/a participante da pesquisa. Cerca de $66 \%$ dos participantes da pesquisa eram árabes ou descendentes, residentes em cidades como São Paulo (SP), Rio de Janeiro (RJ), Campo Grande (MS), Maringá (PR), Curitiba (PR), Foz do Iguaçu (PR), Belo Horizonte (MG), Goiânia (GO), Brasília (DF). Desse grupo, grande maioria era formada

\footnotetext{
${ }^{55} \mathrm{O}$ envio de fotos seguiu após novembro de 2012, e, atualmente, sempre que novas fotos são recebidas, há uma atualização da galeria. No entanto, a análise das imagens para realização dessa pesquisa incluiu os retratos enviados até essa data.
} 
por filhos e netos de sírios e libaneses que chegaram ao Brasil no início do século XX, mas também por pessoas com outro tipo de parentesco com imigrantes e famílias oriundas de outros países, como Palestina e Egito, por exemplo.

Chamou atenção, embora os cristãos representem a maioria dos imigrantes árabes no Brasil, especialmente no período destacado como de maior fluxo migratório, a grande participação de muçulmanos no envio das fotos neste levantamento. $\mathrm{O}$ levantamento realizado nessa etapa exploratória, por meio do recebimento de fotografias também contou com a participação de $34 \%$ de voluntários sem qualquer tipo de ascendência árabe. De acordo com as mensagens enviadas, essas pessoas se sentiram motivadas a participar do levantamento, por meio do envio de fotografias, pelos seguintes motivos: (i) possuem curiosidade em conhecer mais a cultura árabe; (ii) consideram-se admiradores da cultura árabe; (iii) reconhecem a influência da cultura árabe na formação da nossa identidade nacional; (iv) gostaram da ideia do projeto e desejaram contribuir de alguma forma.

As pessoas, de modo geral, descreviam as fotos enviadas, contavam detalhes importantes, os quais muitas vezes revelavam a história de sua família, de uma cidade brasileira ou de costumes regionais. As imagens reunidas provinham de duas principais fontes: (i) registros de família e, (ii) fotografias capturadas no cotidiano brasileiro independente de qualquer ligação com a trajetória familiar das pessoas que contribuíram neste levantamento. Os retratos relacionados a hábitos alimentares e tradições culinárias, bem como momentos de família e festas árabes representam $31 \%$ das fotografias enviadas para o projeto. ${ }^{56}$ Já as imagens de mesquitas e outros elementos religiosos islâmicos compõem $19 \%$ do universo dos retratos recebidos durante o estudo. Traços arquitetônicos que remetem a influência árabe em edifícios, jardins, parques e

${ }^{56}$ Inicialmente, tentou-se calcular a frequência das categorias das imagens recebidas na primeira etapa da pesquisa separando as fotos de comida das fotos de família. Entretanto, boa parte das imagens relacionadas a alimentação também vinham acompanhadas de depoimentos onde o envio daqueles retratos se justificava pela questão muitas vezes emocional, ligada a uma lembrança familiar, como, por exemplo, o almoço de domingo, as festas, a lembrança dos pais e dos avós, entre outros. Nesse sentido, optou-se estabelecer o cálculo percentual das fotos reunindo estes dois grupos de imagens. 
objetos de decoração incorporados ao "gosto" brasileiro foram identificados por $12 \%$ dos colaboradores da pesquisa.

As imagens permitiram uma série de reflexões sobre a forma como a figura do árabe é identificada e representada no Brasil. Trajetórias semelhantes foram contadas por muitos participantes da pesquisa, não apenas nessa etapa exploratória, como posteriormente, nas entrevistas e durante o período de intensas observações participantes, como detalharemos adiante. Observou-se que os depoimentos corroboram o que a literatura consultada para esta pesquisa aponta de forma exaustiva: a grande participação de sírios e libaneses para o desenvolvimento econômico de cidades brasileiras, o apoio de parentes e amigos já instalados no Brasil no processo de adaptação de novos imigrantes e os dispositivos de preservação de identidade encontrados por essas famílias.

Além de indicar aspectos importantes quanto à questão das representações sociais acerca de uma cultura estrangeira em sua sociedade receptora, a fotos também apontaram para uma importante relação entre memória e identidade, seja de imigrantes, de seus descendentes ou até mesmo de cidades brasileiras.

\subsubsection{Memórias de família}

A seguir são mostrados alguns exemplos de como as fotografias enviadas pelos participantes vinham acompanhadas por depoimentos pessoais, de histórias de família ou das cidades onde os participantes viviam.

As duas fotos abaixo foram enviadas por uma filha de libaneses. Seu pai mudou-se para Maringá (PR) na década de 1950 e trabalhou como mascate, antes de se tornar dono de uma loja, que levava o seu próprio nome, como era de costume entre os árabes comerciantes. 


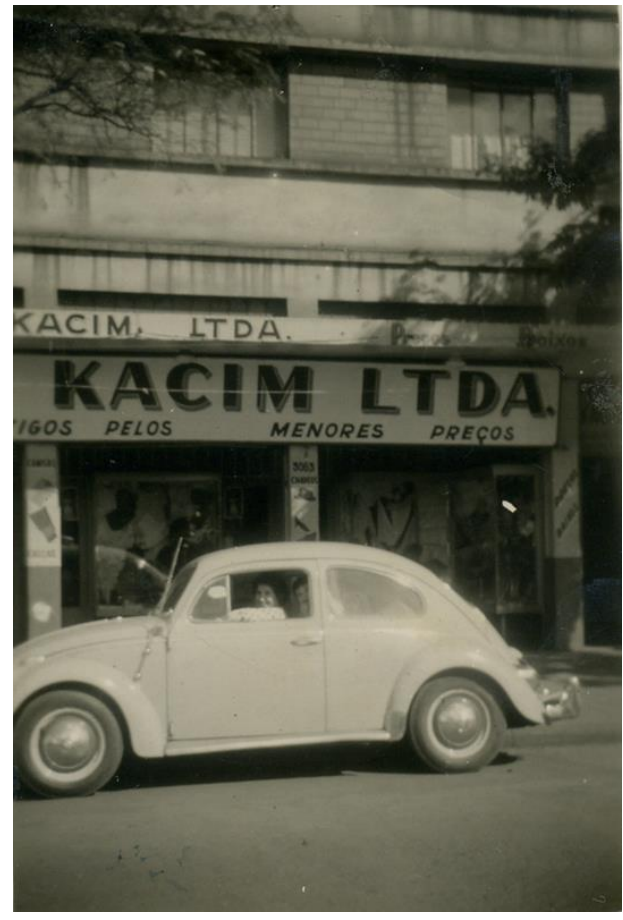

Figura 8 - Fotografia de família

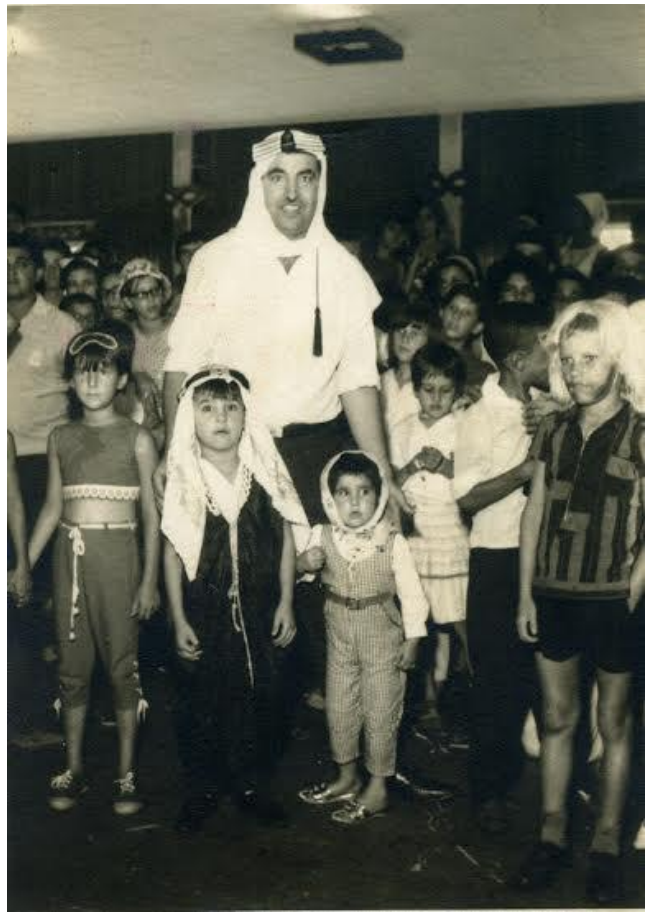

Figura 9 - Fotografia de família

Seguem fotos referentes ao pioneirismo do meu pai K.M.A. ao chegar em Maringá (norte do Paraná) na década de 50. As fotos são da década de 60 (entre 1961 e 1967). Vocês podem observar como era a fachada da Casa Kacim Ltda., inaugurada em 1954 (uma das primeiras na Av. Brasil - a principal da cidade), uma das mais populares e inesquecíveis casas de comércio da cidade de Maringá. Ficou eternizada pelas brilhantes propagandas inéditas e avassaladoras para a época. A foto tirada dentro da loja deve ser de 1964, nela aparecem meu irmão, minha mãe e meu pai. Já a foto em que estamos fantasiados (1967), foi tirada no Clube Olímpico de Maringá (recém inaugurado). Meu pai fazia questão de nos levar devidamente caracterizados, no sentido de divulgar a cultura e as tradições árabes. Penso que estas fotos mostram bem a força, a coragem e o amor dos nossos pais pela cultura e pela terra que os recebeu. (Trecho de depoimento enviado por S.A.E.K., filha de libaneses, junto a algumas fotos, como colaboração ao estudo).

A próxima fotografia apresentada foi enviada pelo filho de um imigrante sírio que chegou ao Brasil em 1918. Ele saiu de seu país fugindo da Primeira Guerra Mundial, como 
muitos outros árabes que desembarcaram no Brasil. Trata-se de um documento de identidade, onde é possível observar também que o imigrante trabalhava como comerciante. No depoimento enviado junto à imagem, percebia-se o pesar manifestado pelo filho em relação às poucas oportunidades que ele teve de conviver com seu pai, que faleceu quando ele tinha apenas dez anos.

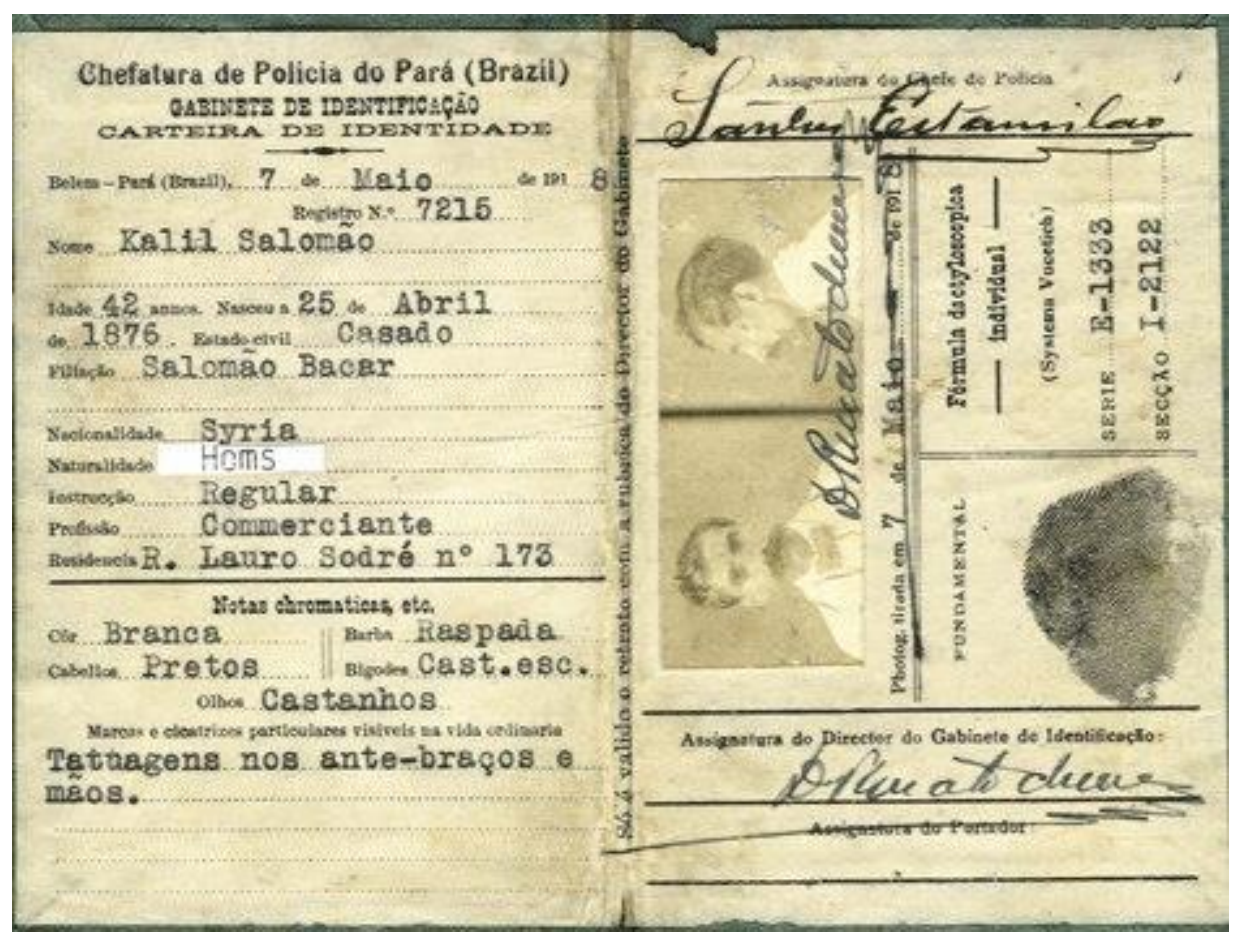

Figura 10 - Documento de família

[...] Ainda assim, repassei à L. e ao L.N. uma foto da carteira de identidade que meu pai recebeu quando chegou ao Brasil, em 1918, fugindo da primeira grande guerra! Não tenho outros documentos nem grandes lembranças porque, quando ele morreu, tinha apenas 10 anos completos e minhas tentativas de abordagem ao arabismo foram sempre frustrantes. Não encontrei, nas tentativas que fiz, nenhuma receptividade animadora, nem ambiente parecido com aquele da minha infância, em casa com meu velho pai - a pessoa mais solidária e tolerante que conheci nestes meus 85 anos de vida. Restou-me, então, tentar imitá-lo quanto possível e estou aqui ao seu dispor para o que estiver ao meu alcance limitadíssimo. Suponho que já lhe tenham enviado a cópia da carteirinha acima mencionada. Mas em caso negativo e, se lhe interessar, basta avisar-me que o farei. Disponha do amigo ao seu dispor S.K.B. (Trecho 
de depoimento enviado por S.K.B, filho de um imigrante sírio, como colaboração ao estudo)

Sobre a fotografia anterior, merece menção ainda o fato de que, um ano após a realização desta pesquisa exploratória, tentei entrar em contato com o Sr. S.K.B. para convidá-lo a participar da etapa de aprofundamento da pesquisa por meio da realização de uma entrevista (no final de 2012). Porém, fui informada por seus familiares que ele havia falecido. Gostaria de deixar registrado, por fim, que sua neta me contatou em outra ocasião para agradecer a oportunidade dada ao seu avô de contar um pouco sobre a história de sua família.

Ainda com o intuito de mostrar como a fotografia recupera histórias de família e, consequentemente, permite que sejam dados distintos olhares para uma mesma imagem, dependendo de quem a vê ou quem a descreve, o depoimento a seguir (e as duas imagens apresentadas em sequência) foi enviado por uma neta (e filha) de sírios junto com fotografias e recortes de jornal com notícias relacionadas à presença de sua família em Campo Grande (MS), cidade que recebeu muitos sírios e libaneses, embora a literatura sobre a imigração árabe no Brasil não tenha ainda se dedicado a essa região quanto ela merece.

Tenho algumas coisas da minha família... do meu avô, que veio da Síria, com minha avó e os filhos.... aí estou te enviando... não sei se serve...e abaixo da história dele...tem até uma propaganda da Confeitaria árabe, que fica na rua 7 de setembro, aqui em Campo grande / Mato Grosso do Sul. Essa rua [...] é cheia de lojas do povo árabe, tem lojas de comida, doces, fumo para arguile de tudo um pouco... (Trecho de depoimento enviado por C.C., neta e filha de sírios, como colaboração ao estudo) 


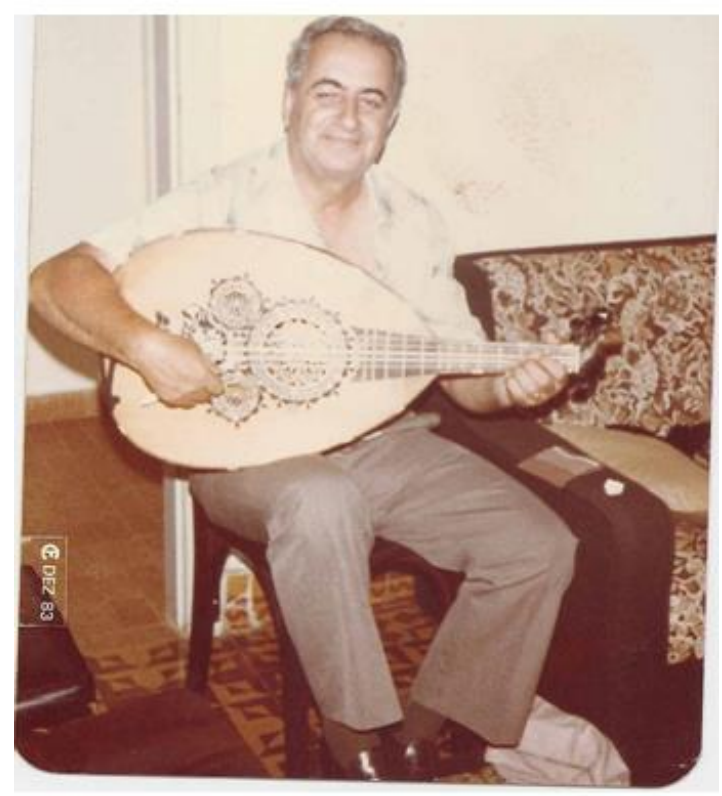

Figura 11 - Fotografia de família

CANTINHO DA SAUDADE
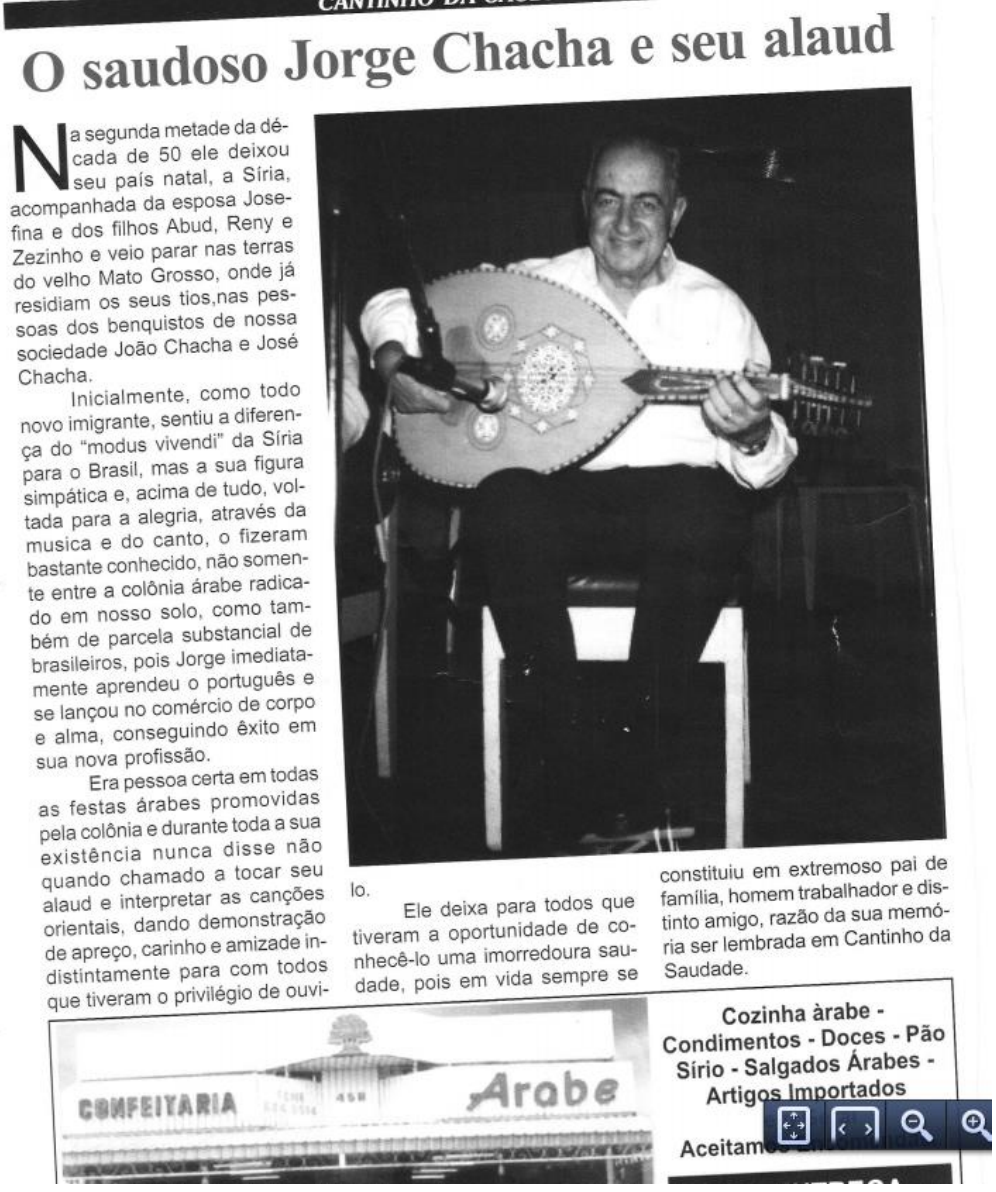

Figura 12 - Recorte de jornal (registro de família) 
A próxima imagem foi enviada junto a outros quatro arquivos que, juntos, contavam a história de uma família composta por cerca de 170 descendentes de um libanês que chegou ao Brasil em 1890. Algumas informações se sobressaem no trecho do depoimento estacado, logo abaixo do recorde de jornal encaminhado por uma de suas netas. Em primeiro lugar, observa-se a ênfase dada à questão da "mistura religiosa", pois a família é formada por maronitas e muçulmanos. Também chama atenção o esforço empreendido pelos familiares para manterem-se unidos, por meio de uma grande festa anual, que visa declarar seu amor à origem árabe e ao patriarca libanês.

\section{Árvore genealógica}

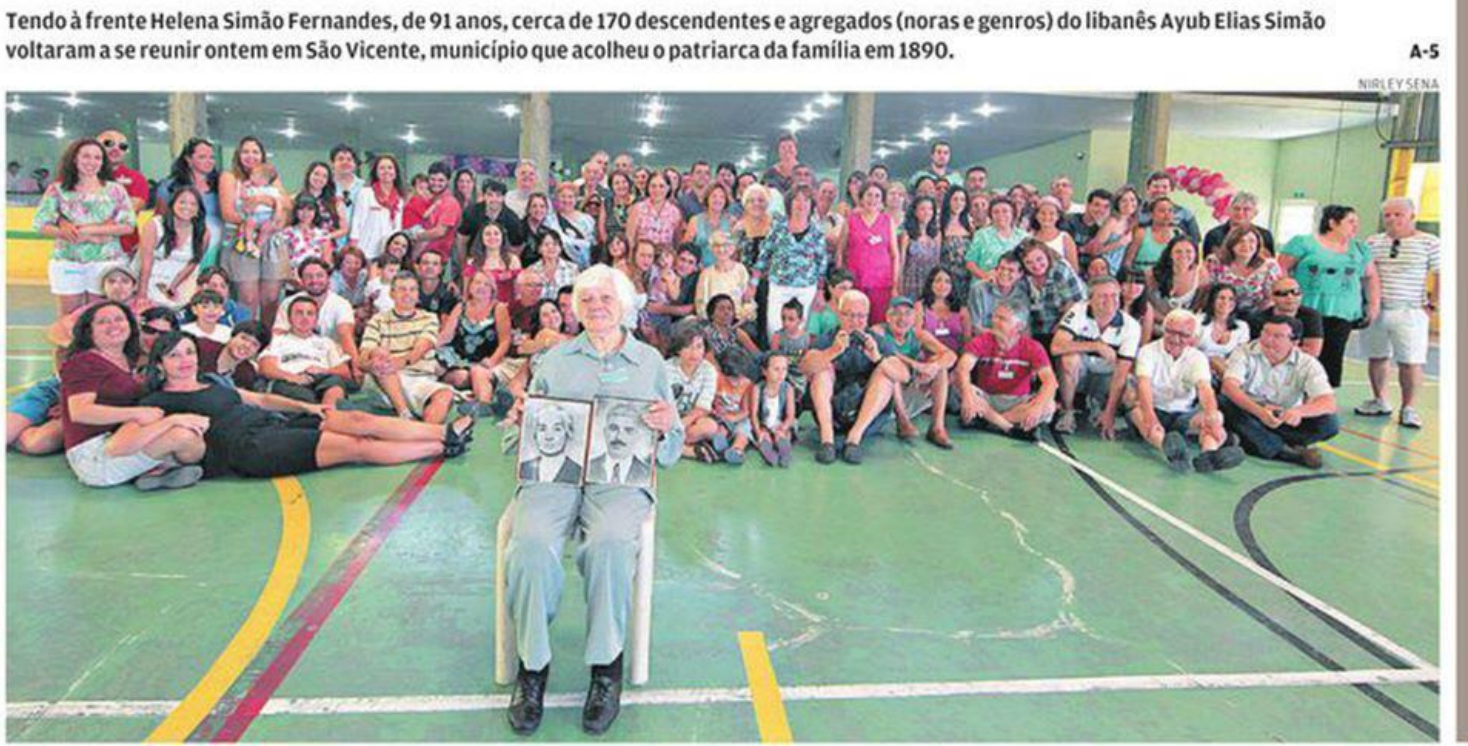

Figura 13 - Recorte de jornal (registro de família)

Meu nome é L.B.K., sou neta de libaneses por parte de pai e casada com libanês nato. Minha família é uma mistura religiosa, com maronitas e muçulmanos, mas todos compartilham o sangue libanês e o amor ao país dos nossos ancestrais. Não sei se minhas fotos lhe serão úteis, mas se forem ficarei feliz. A família costuma reunir-se uma vez por ano em uma grande festa para declararmos nosso amor à origem árabe e saudar nosso querido patriarca A.E.S., que chegou aqui em São Vicente (Litoral de São Paulo) 
junto aos primeiros imigrantes libaneses. Domingo passado foi o dia da esperada festa das raízes e lhe envio em pdf a notícia com fotos publicada no jornal regional, além de algumas outras fotos. (Trecho de depoimento enviado por L.B.K., neta e filha de sírios, como colaboração ao estudo).

Algumas fotografias, embora não fossem de álbuns de família, indicavam outro tipo de preocupação relacionada à questão da memória e identidade árabe no Brasil, pois as imagens capturavam eventos sociais, centros culturais ou ambientes frequentados pela chamada "comunidade árabe" no Brasil. O retrato a seguir é um desses exemplos e mostra um grupo de pessoas interpretando o dabke, uma dança popular, executada geralmente em festas, casamentos, jantares ou encontros entre árabes, especialmente libaneses, sírios, jordanianos e palestinos. No depoimento enviado como colaboração à pesquisa, a participante ressalta a importância de haver um lugar tipicamente árabe em Campo Grande (MS), frequentado não apenas por árabes e descendentes, mas também por brasileiros.

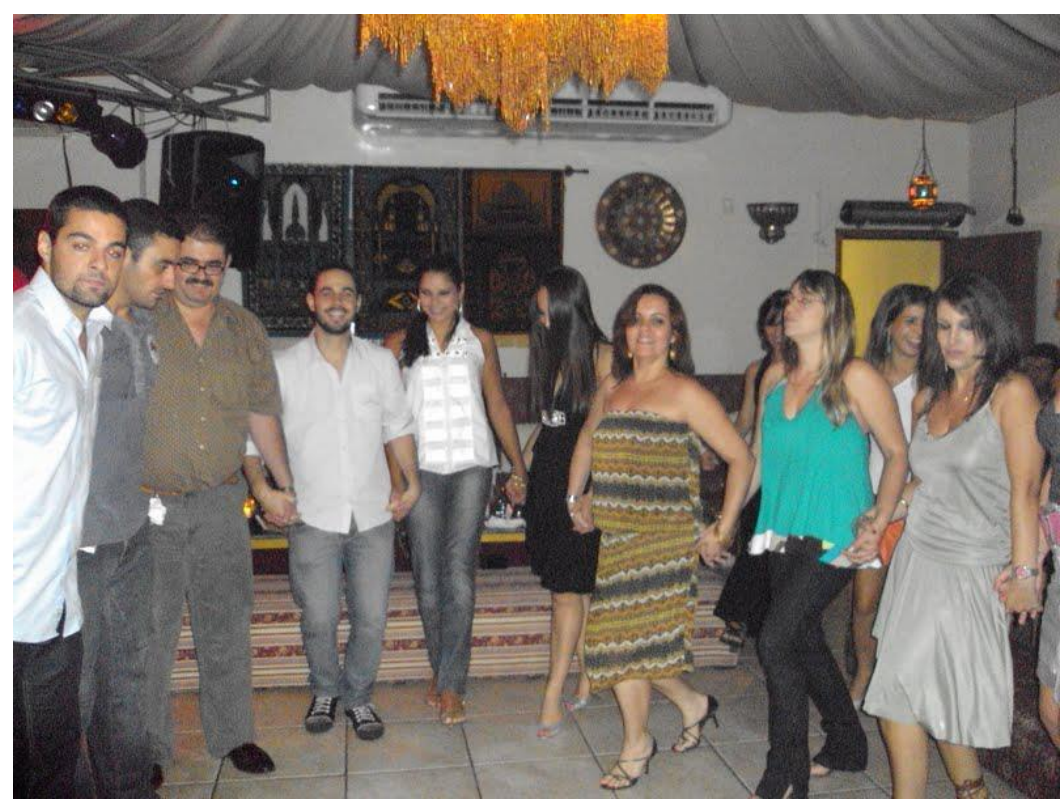

Figura 14 - Registro de evento festivo em um centro cultural árabe em Campo Grande MS 
Moro em Ponta Porã - MS, meu nome é S. R. M. nascida em São Vicente-SP, sou filha de R. F. M., libanês. Gostei muito do projeto e gostaria de colaborar. As fotos que envio, foram tiradas por mim, em Campo Grande- MS, no centro cultural árabe chamado Ariche. Acho interessante enviar essas fotos, pois o Ariche é um típico lugar árabe frequentado por muitos descendentes e por muitos brasileiros. (Trecho de depoimento enviado por S.R.M., filha de libanês, como colaboração ao estudo)

\subsubsection{Fotografia e história}

As fotografias também revelaram o olhar dos participantes em relação a um tipo de reconhecimento de presenças árabes no Brasil que não se deu pela via da imigração. Nos capítulos anteriores procurou-se apresentar essa discussão, além de mostrar de que forma pensadores preocupados com o caldeamento das nossas matrizes culturais chamaram atenção para o reconhecimento de uma influência "moura" em nosso cotidiano. Essas influências foram registradas pelos participantes da pesquisa de diversas formas, que serão mostradas a seguir.

A primeira imagem apresentada nesta seção foi feita em Mucugê, na Bahia, e mostra o Cemitério Santa Izabel, que também é conhecido como Cemitério Bizantino em virtude do formato dos mausoléus ali construídos. Ele data de 1855, quando um surto de cólera atingiu a região e devido ao alto índice de mortalidade dos povoados, ficou proibido, como medida de controle epidêmico, enterrar os corpos nas igrejas. Consequentemente, as decorações e adornos deste cemitério buscaram imitar as igrejas da época, que eram fortemente influenciadas pelo estilo gótico, e, embora não sigam um único padrão arquitetônico, há uma predominância das formas pontiagudas na cor branca ${ }^{57}$.

\footnotetext{
${ }^{57}$ Os bizantinos herdaram a tradição romana de utilizar construções como ferramentas de dominação política. No entanto, bizantinos focaram-se na edificação de igrejas, monastérios (que geralmente eram amplos conjuntos de edificações que incluíam hospitais, albergues, banhos e jardins) e estruturas defensivas.
} 


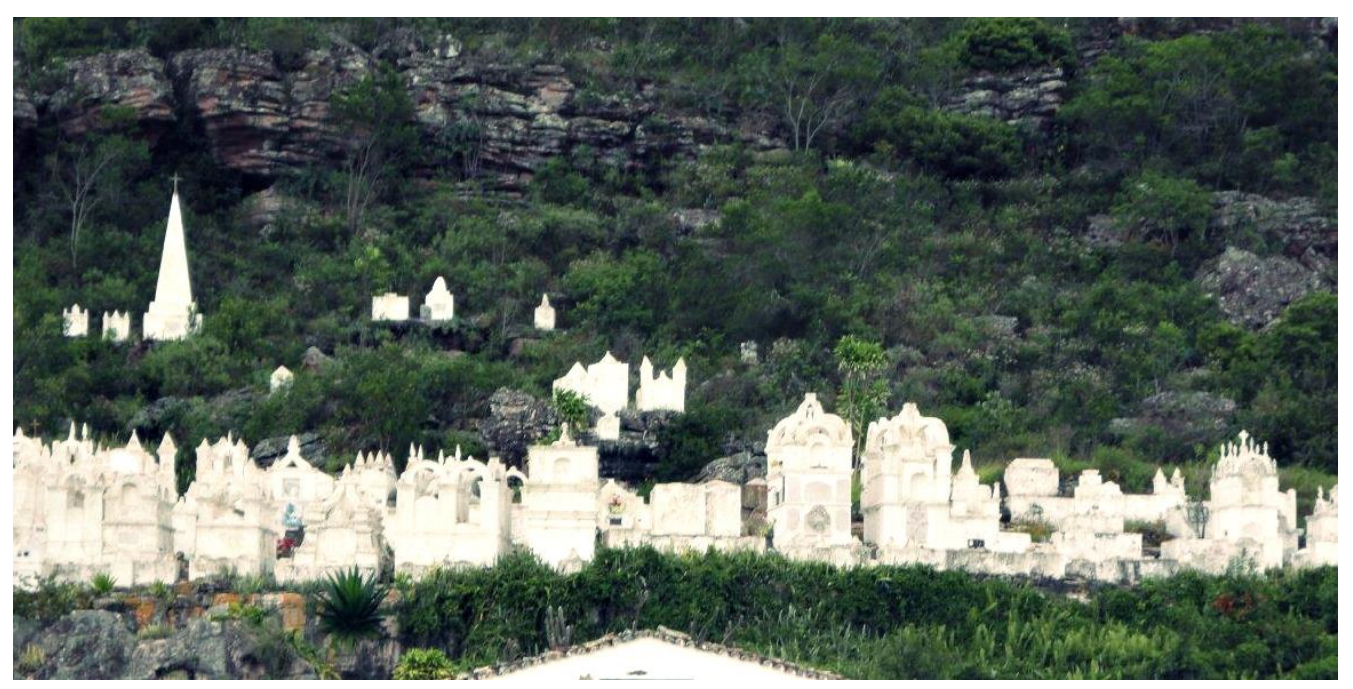

Figura 15 - Cemitério Bizantino em Mucugê - BA

As fotos mostram o cemitério Santa Izabel (cemitério bizantino), localizado na encosta da Serra do Sincorá, em Mucugê (BA), sul da Chapada Diamantina. Os mausoléus caiados têm sua origem na geologia da cidade. Mucugê está assentada sobre uma rocha muito dura, tornando difícil cavar "sete palmos" para enterrar os mortos. Os mais pobres eram colocados em fissuras das rochas, fechadas com pedras, e os mais abastados iam para os mausoléus do cemitério, à beira da estrada. A denominação "bizantino" se refere ao formato dos jazigos, que lembram a arquitetura de Bizâncio, antiga capital do Império Turco-Otomano. A influência se deve, provavelmente, aos imigrantes árabes (libaneses e sírios) que se instalaram na cidade durante o ciclo do diamante, que teve seu auge nas décadas de 1840 a 1870. O conjunto arquitetônico do cemitério bizantino foi tombado pelo IPHAN em 1980. (Trecho de depoimento de F.H.S.L, que não possui ascendência árabe, enviado como colaboração ao estudo)

Disponível em: http://imperiobizantino.com.br/2011/11/21/entendendo-a-arquitetura-bizantina/. Acesso em: set. 2014. 
Observações deixadas pelo autor da fotografia: 1. Morador de Brasília DF 2. Provável ascendência árabe, porém não comprovada. Minha família, originária de Portugal, de sobrenome "Moura Fé" (cristãosnovos, certamente), mudou de nome para "Sousa" ao chegar no Brasil. Os registros históricos sumiram, junto com o sobrenome.

A próxima fotografia é uma das quatro imagens recebidas durante a pesquisa da Igreja Nossa Senhora da Conceição, em Salvador (BA), também conhecida como Igreja da Lapinha. Ela foi fundada em 1771 e possui uma forte influência mourisca, contando, inclusive, com inscrições em árabe em seu interior. O trecho do depoimento enviado junto à foto selecionado para ilustrar o retrato conta um pouco sobre sua história.

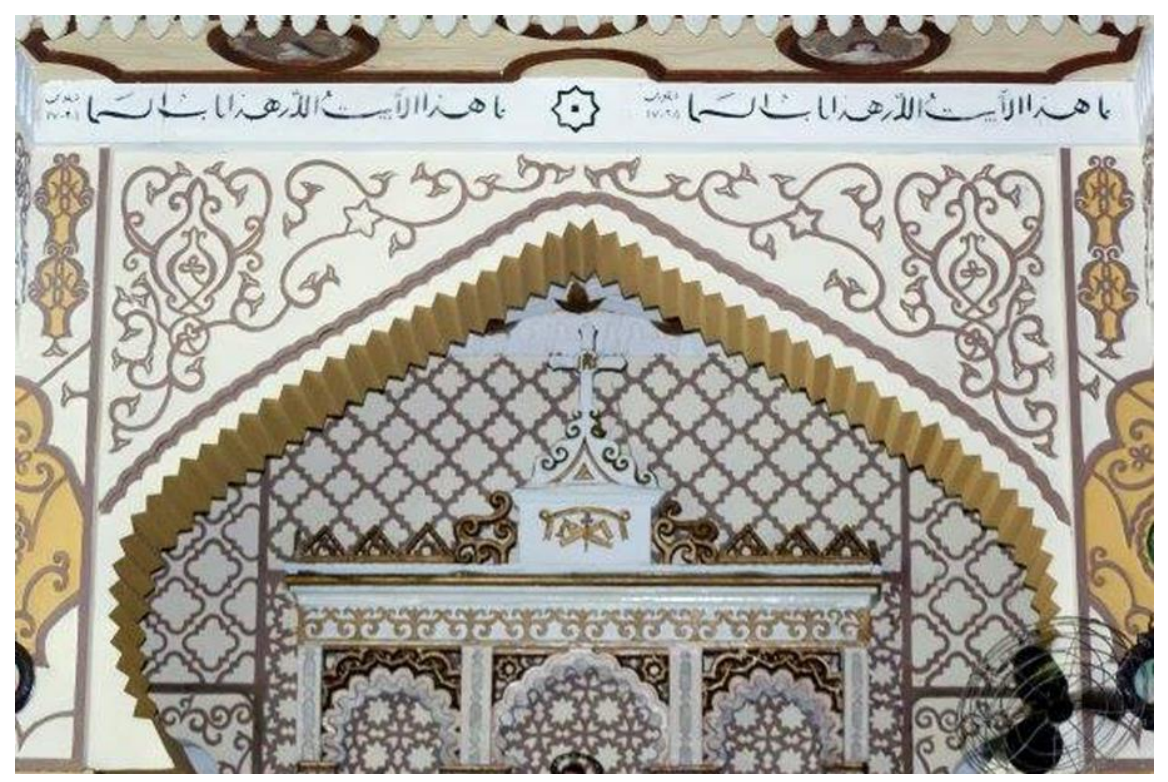

Figura 16 - Interior da Igreja Nossa Senhora da Conceição em Salvador (BA)

Estas são fotos da presença mouro-árabe aqui na Bahia. São imagens da igreja da lapinha. Seu arquiteto era um agostiniano do sul da Espanha, cidade de Granada, de onde se inspirou para construir essa igreja! [...] É uma igreja católica e não uma mesquita! Abraços de Salvador. (Trecho de depoimento de R.B., residente em Salvador - BA) 
As próximas três fotos mostram o olhar dos participantes acerca da presença árabe no Brasil por meio da outros prismas, tais como a língua portuguesa, a arquitetura e a dança.

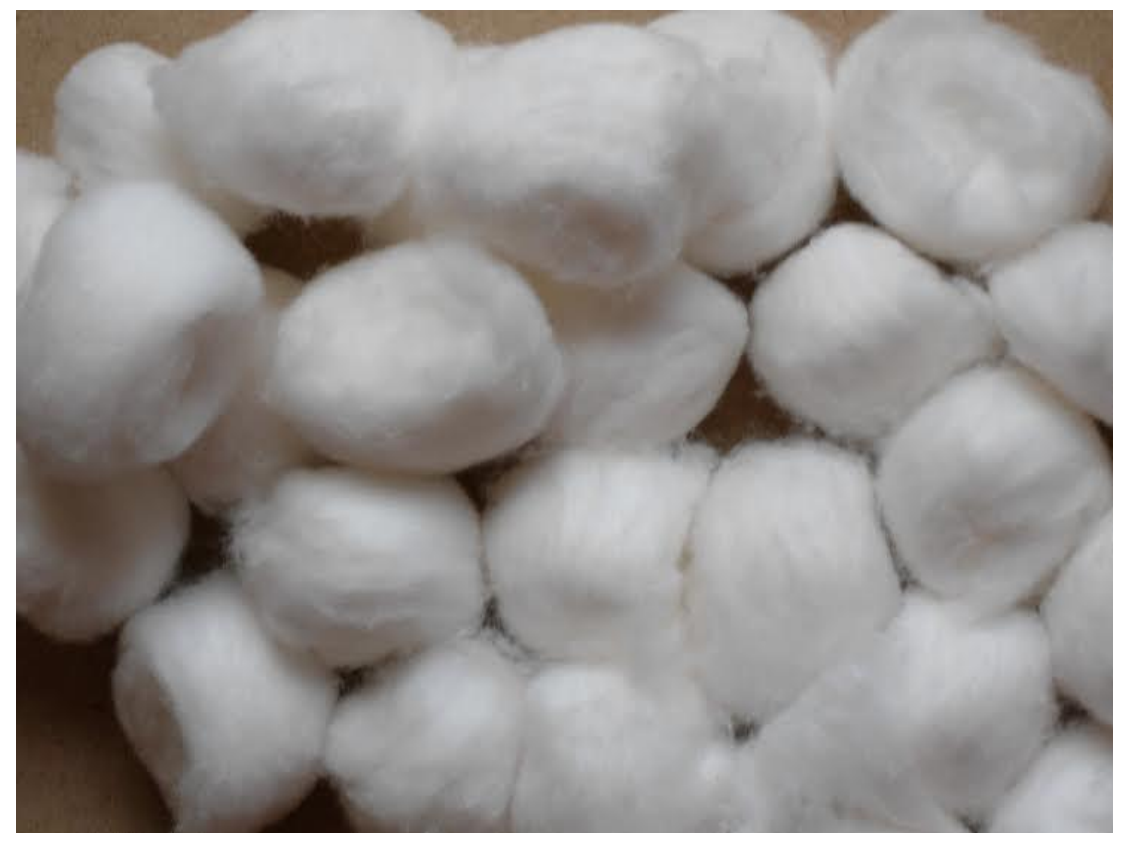

Figura 17 - Algodão, uma das muitas palavras de origem árabe na língua portuguesa

[...] Não tenho ascendência árabe. As fotos buscam retratar as diversas palavras de origem árabe presentes em nosso cotidiano, como por exemplo: algodão e almofada. (Trecho de depoimento de M.T.M.S, que não possui ascendência árabe, enviado como colaboração ao estudo) 


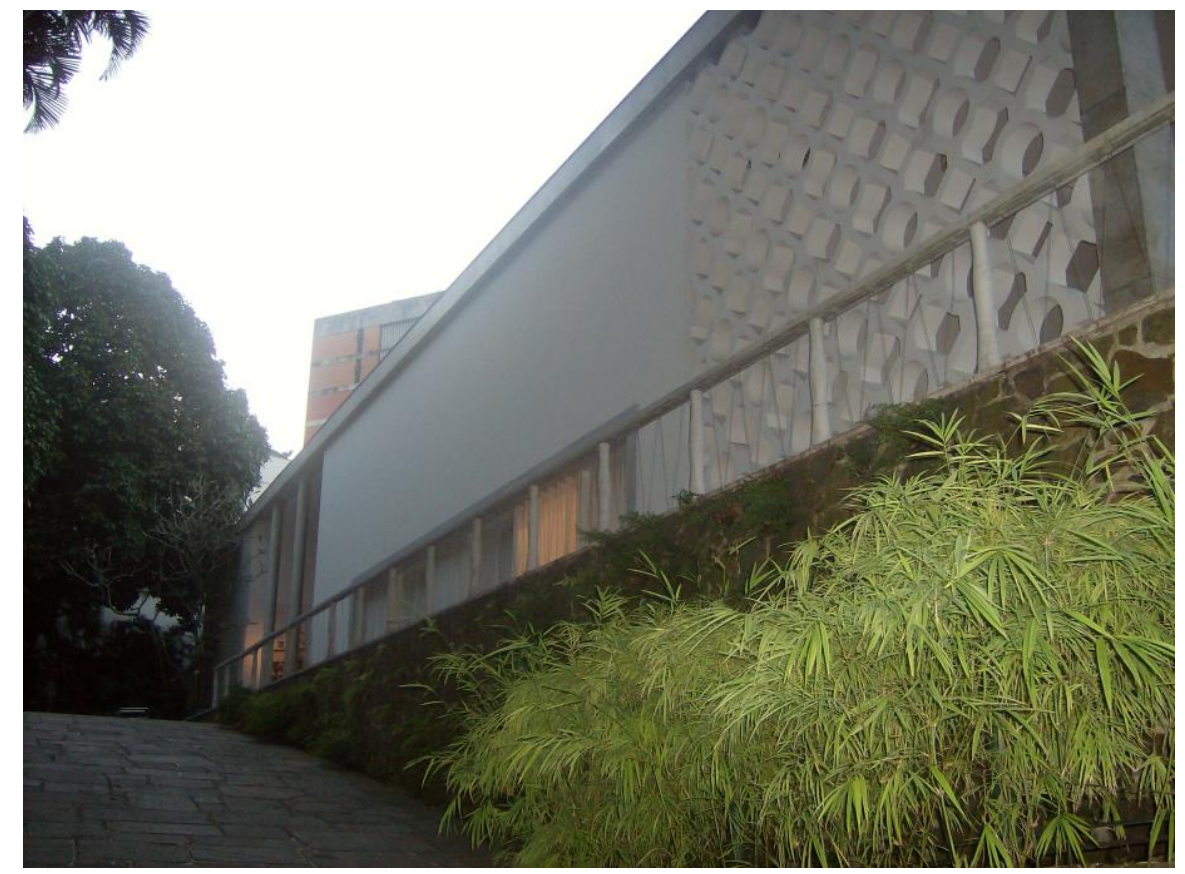

Figura 18 - A influência dos muxarabis na arquitetura brasileira

Seguem 3 fotos tiradas por mim, no Instituto Moreira Salles, aqui no Rio. Não sei se são boas o suficiente, mas representam uma das coisas que, para mim, mais refletem a presença árabe no Brasil, que é o uso dos muxarabis na arquitetura. Não sei até que ponto muxarabi é uma palavra de conhecimento geral, mas são esses elementos vazados, tipo treliça que vemos em muitos edifícios modernistas em Brasília. O muxarabi árabe forma desenhos e geralmente é em madeira, mas aqui nós "abrasileiramos" esse tipo de elemento e criamos o cobogó. No Moreira Salles tem dos dois tipos, na foto da fachada do prédio dá pra ver um cobogó em concreto e nas outras os muxarabis em madeira. É um elemento fantástico, pois permite a passagem da luz e do vento sem deixar ver o que está do outro lado. (Trecho de depoimento de P.A., bisneta de libanês, enviado como colaboração ao estudo) 


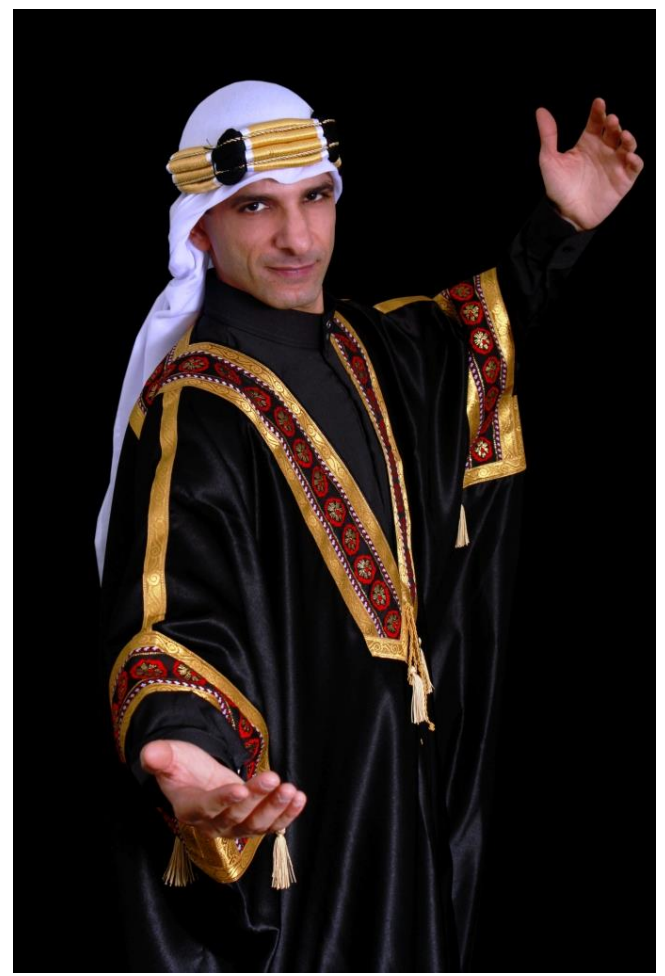

Figura 19 - Exemplo de divulgação da dança folclórica árabe em Juiz de Fora

Olá, será um grande prazer participar em vosso projeto! Quando falamos sobre presença árabe no Brasil, na minha cabeça vêm as danças festivas, culinária árabe e hospitalidade... Segue em anexo a foto. (Trecho de depoimento enviado por T.N., libanês, junto a uma foto como colaboração ao estudo)

\subsubsection{O registro de alimentos, hábitos e tradições culinárias árabes no Brasil}

Como mencionado anteriormente, chamou a atenção a quantidade de fotografias enviadas para o projeto que retratam alimentos, hábitos e tradições culinárias árabes identificadas ou preservadas no Brasil, quase sempre relacionadas a algum tipo de evento social ou lembrança familiar.

As imagens de alimentos, hábitos e tradições culinárias árabes no Brasil parecem permitir, de um lado, um resgate da história das famílias de origem árabe, pois ela está ligada à memória afetiva desses grupos, uma vez que a maioria dos eventos sociais e familiares esteve relacionada ao ato de comer e festejar. Por outro lado, a observa-se que 
também por meio da comida, a sociedade - independente de sua origem - reconhece as influências e contribuições das diversas presenças árabes no Brasil na cozinha brasileira.

Dentre as fotografias recebidas, estão imagens de tâmaras, nozes, damascos, coalhada, pão sírio, doces diversos, livros de receitas, cardápios, restaurantes sírios e libaneses localizados em várias partes do país, além de eventos familiares fortemente marcados por reuniões ao redor de mesas repletas de pratos árabes. Já as descrições enviadas junto a estes retratos falam sobre hábitos ainda cultivados nas famílias descendentes, mas também de hábitos incorporados pelos brasileiros, como bem ilustram os comentários enviados por participantes do projeto, alguns dos quais podem ser lidos a seguir.

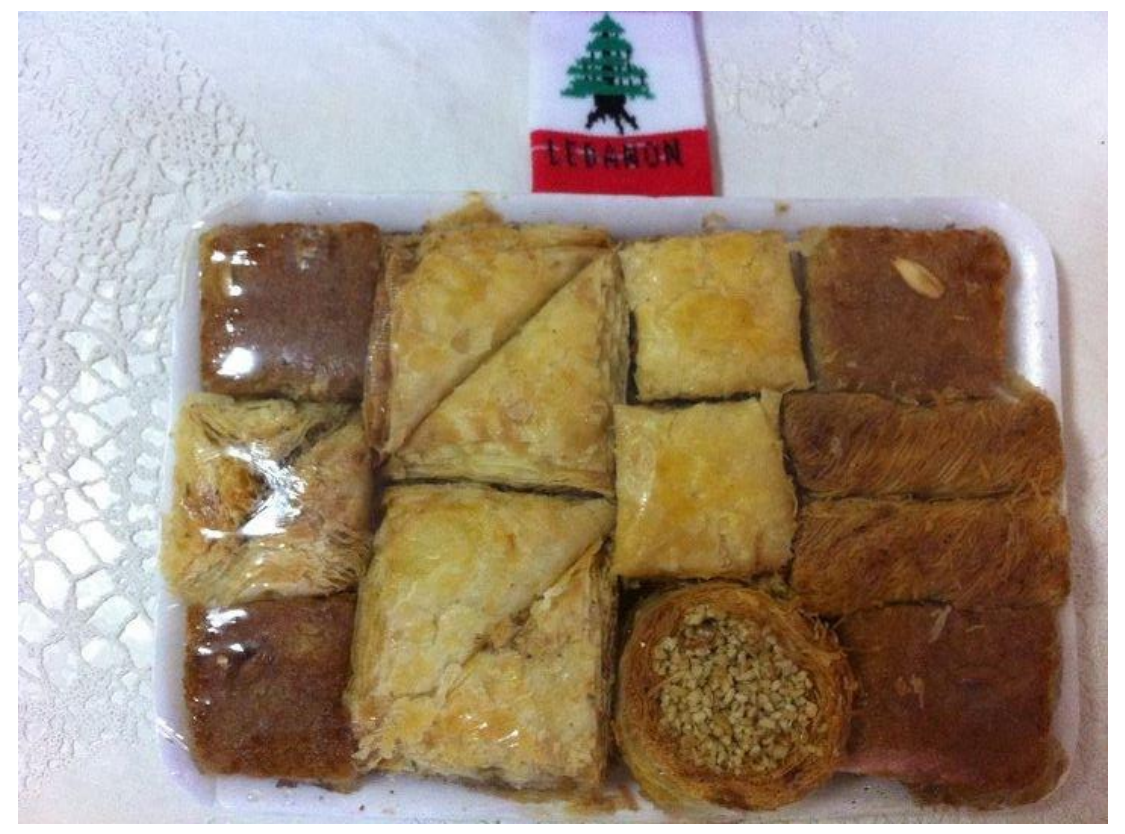

Figura 20 - Doces árabes comprados em um empório da Rua 25 de Março

Essas e outras delícias árabes, eu costumo comprar nas adjacências da Rua 25 de Março, onde se concentram inúmeros restaurantes, empórios, lanchonetes etc. da culinária Árabe. Essa bandeja de doces custou $\mathrm{R} \$ 25,00$, com 12 unidades variadas, o que é muito vantajoso porque 1 unidade custa em torno de $\mathrm{R} \$ 3,50$ a $\mathrm{R} \$ 5,00$ de acordo com o tipo do doce. Essa bandeja, eu comprei precisamente na Rua Afonso Kherlakian, em uma lanchonete que possui um empório de especiarias Árabes. Vale a 
pena conferir. (Trecho de depoimento de J.A., que não possui ascendência árabe, enviado como colaboração ao estudo)

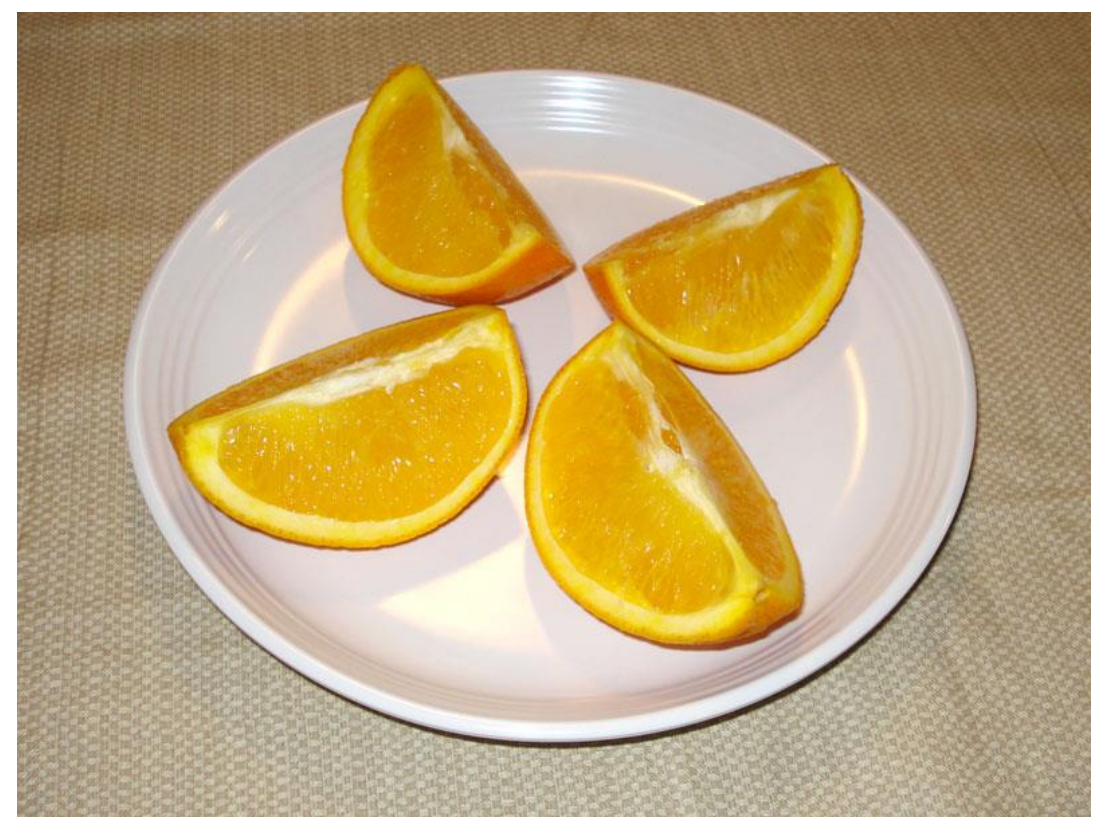

Figura 21 - Tradição árabe preservada na forma de cortar a laranja

Minha foto é sobre a forma de cortar a laranja. Minha avó Nazira, filha de sírios, ensinou a meu pai, que sempre cortava assim para mim. Eu só soube da influência árabe quando Seu João Batista me contou que na casa dele também se cortava desse jeito! (Trecho de depoimento enviado por C.E., neta de sírios, enviado como colaboração ao estudo) 


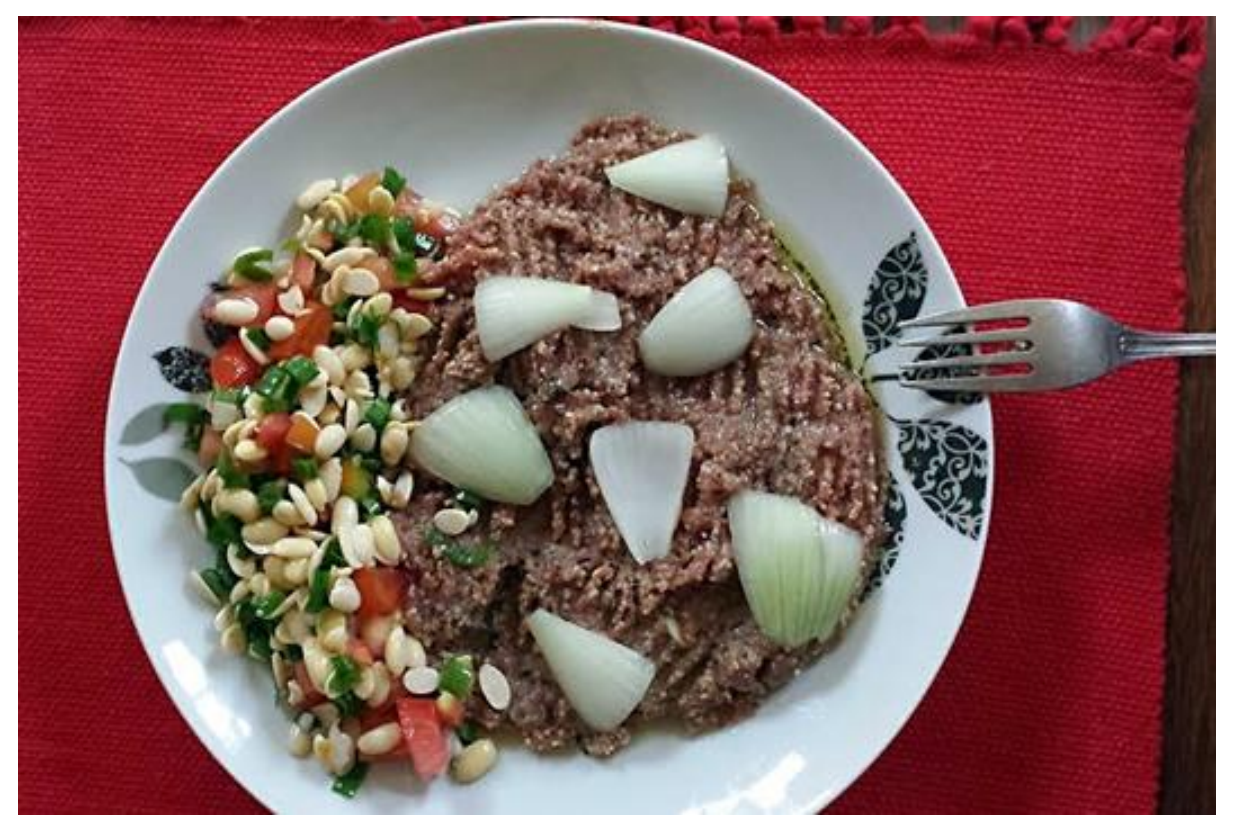

Figura 22 - Comida tradicional: quibe cru com Snoubar (também conhecido como Pinoli)

Perdoe a simplicidade da foto, mas são coisas incorporadas ao nosso cotidiano, e que nos tocam. (Trecho de depoimento enviado por M.V., que não possui ascendência árabe, enviado como colaboração ao estudo).

As fotografias reunidas na etapa exploratória desta pesquisa permitiram observar que a comida se destacou, dentre os elementos recorrentes nos registros fotográficos, como importante fenômeno de construção e afirmação de uma espécie de identidade "árabe" no Brasil, constatação que, posteriormente, foi reforçado nas demais etapas de coleta de dados da pesquisa, conforme será observado adiante. 
Foi possível notar ainda que as imagens extrapolam uma visão elaborada exclusivamente pelo imigrante e seus descendentes. Chama atenção o interesse por parte daquelas pessoas que não possuem qualquer parentesco ou origem árabe em torno do assunto. Ao que parecem indicar, elas sugerem um sentimento de reconhecimento e pertencimento, em determinados momentos, em relação à influência "moura" herdada via cultura ibérica e, em outros, em relação ao aporte cultural de imigrantes árabes (cuja maioria foi de sírios e libaneses) na construção de uma identidade nacional brasileira.

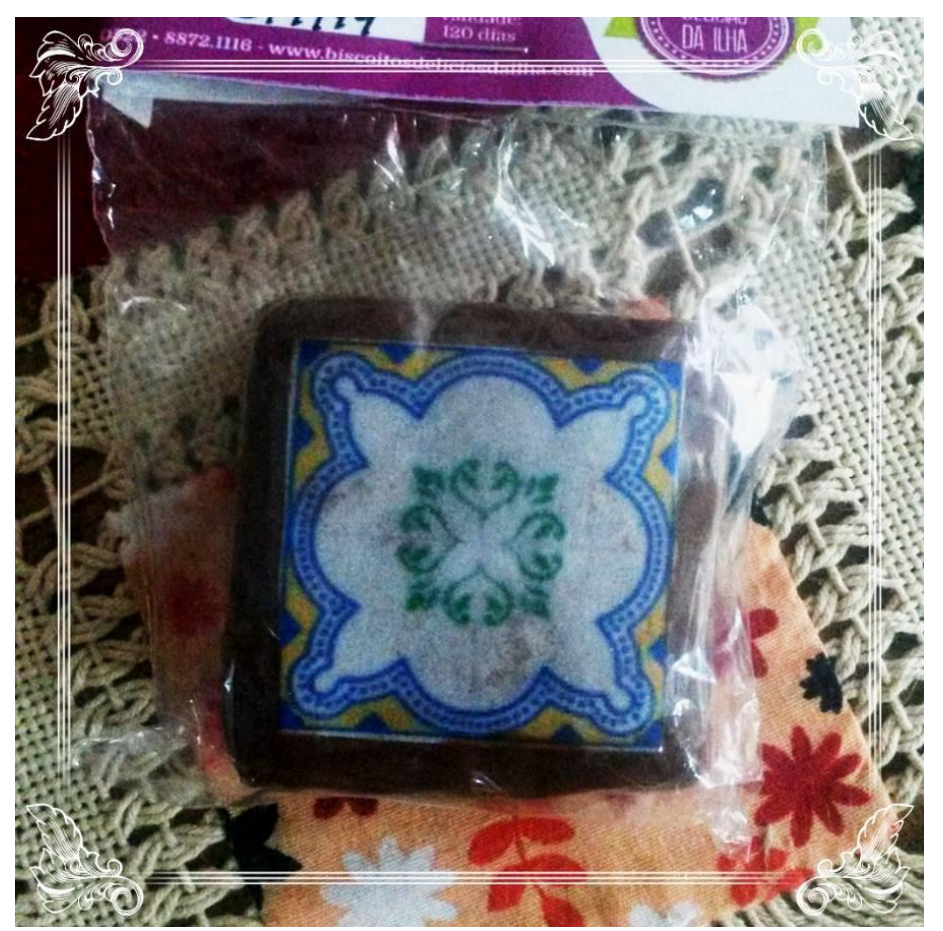

Figura 23 - Doce maranhense decorado na forma de azulejo com inspiração em arabesco

Foto enviada por P.G., que não possui ascendência árabe, como contribuição ao projeto Presença Árabe no Brasil em Imagens.

O alfenim que aparece na foto seguinte é um dos exemplos de doces que fazem parte da cultura brasileira e que foram trazidos entre tantos hábitos e tradições culinárias de origem árabe por espanhóis e portugueses. Câmara Cascudo e Gilberto Freyre, como mostrado anteriormente, chamaram atenção para este e outros pratos reconhecidamente de origem árabe. Cascudo assinalava que, com a introdução da cana-de-açúcar nas lavouras 
brasileiras, bem como a tradicional doçaria portuguesa, vários doces e tradições orientais antes presentes no cotidiano português, também se fizeram presentes na doceria brasileira.

No século VIII, os árabes invadem e ocupam a Península Ibérica e terá sido nessa altura que introduziram esta gulodice, confeccionada com açúcar ou melaço de cana, designada por 'al-fenid' ou 'al-fanid' significando a palavra árabe branco ou alvo e derivando em 'alfenim' na língua portuguesa e que era um doce muito popular no sul de Portugal. ${ }^{58}$

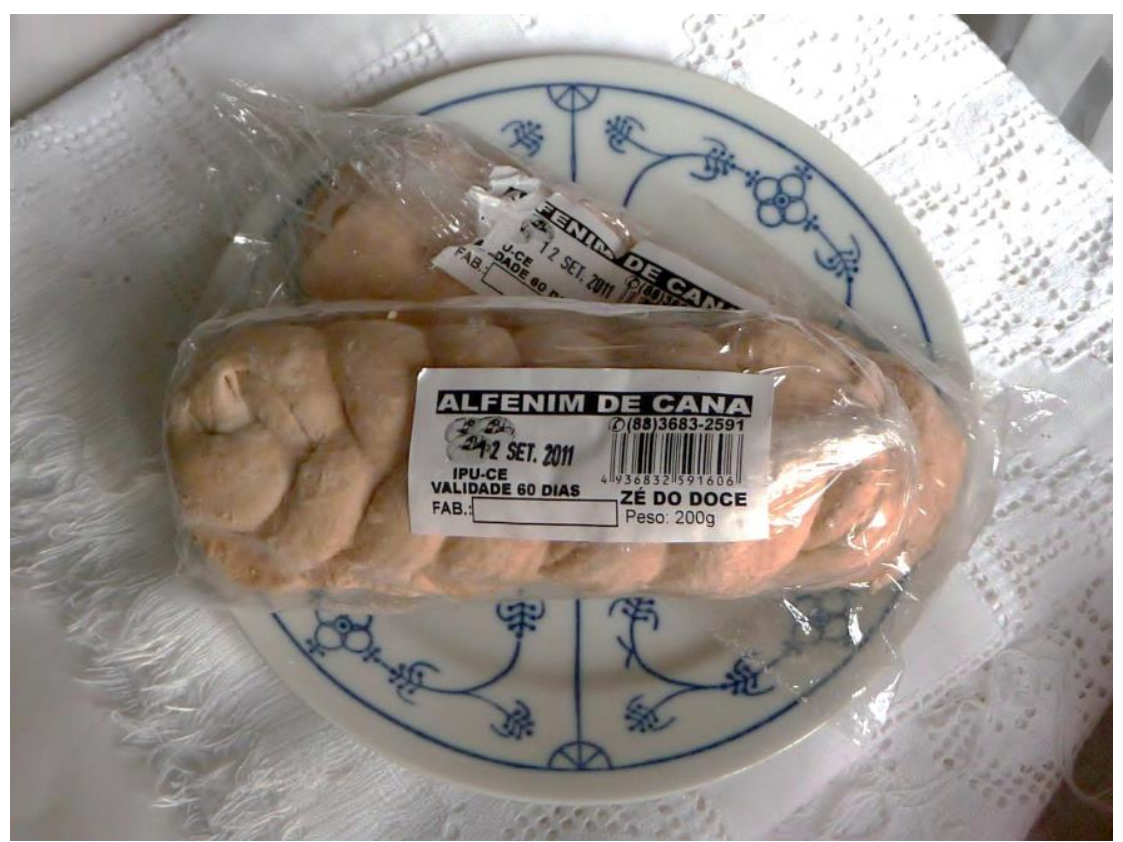

Figura 24 - Alfenim de cana, um dos exemplos da herança árabe na culinária brasileira

Foto enviada por A.E.E., que não possui ascendência árabe, como contribuição ao projeto Presença Árabe no Brasil em Imagens.

Outros exemplos poderiam ser mencionados nesta seção, pois o conjunto de fotografias reunidas na primeira etapa da pesquisa é extenso e bastante rico. Entretanto,

58 Disponível em: http://guiasinterpretesacores.blogspot.com.br/2007/06/alfenim-o-sabor-rabe-no-ritualcristo.html. Acesso em: ago. 2014. 
muitas das informações, por terem sido reiteradas por meio das entrevistas e observação em campo, serão outra vez tratadas nos itens 4.2 e 4.3 deste capítulo.

\title{
4.2 As visitas de campo e as entrevistas realizadas
}

\begin{abstract}
Memória individual e coletiva (social) se sustenta da memória histórica e são socialmente trabalhadas. Possuem registros e informações importantes a serem transmitidas, essencialmente, com a função de garantir o sentimento de pertinência entre os membros do grupo. Diferente da memória histórica que possui como principal meio de preservação e comunicação, a escrita, a memória individual e coletiva tem a oralidade como veículo fundamental, porém não específico. Memórias individuais, coletivas e históricas se adentram mutuamente. Memórias individuais e coletivas almejam a coexistência e a afirmação como memória histórica. (BOTELHO, 2012)
\end{abstract}

Chama atenção especialmente por essa pesquisa tratar de temas como identidade e alimentação, a noção de memória coletiva, inaugurada por Halbwachs e posteriormente recuperada por Michael Pollak, entre outros, que nos permitirá desenvolver importantes reflexões quanto ao tema das construções identitárias e, mais ainda, quanto ao sentimento de pertencimento dos imigrantes. Recorrendo a Pollak (1989), a memória é a "operação coletiva dos acontecimentos e das interpretações do passado que se quer salvaguardar" e ela está integrada em "tentativas mais ou menos conscientes de definir e de reforçar sentimentos de pertencimento e fronteiras sociais entre coletividades de tamanhos diferentes: partidos, sindicatos, igrejas, aldeias, regiões, clãs, famílias, nações etc.”.

A entrevista na pesquisa qualitativa, ao privilegiar a fala dos atores sociais, permite atingir um nível de compreensão da realidade humana que se torna acessível por meio de discursos, sendo apropriada para investigações cujo objetivo é conhecer como as pessoas percebem o mundo (FRASER \& GONDIM, 2004). De tal modo, acreditou-se ser possível pensar na utilização da memória oral enquanto recurso metodológico investigativo que poderia contribuir sobremaneira nos estudos acerca das migrações, tanto como apoio 
para reconstrução das trajetórias de fenômenos migratórios a partir dos seus agentes como na compreensão de seu processo de adaptação e integração nas sociedades receptoras.

Ao longo desta pesquisa, foram realizadas entrevistas em duas modalidades: face a face e mediada, as quais tiveram início em dezembro de 2012, logo após a primeira análise das fotografias recebidas no âmbito do projeto Presença Árabe no Brasil em Imagens, tão $\operatorname{logo}$ o site completou um ano de existência. Essa etapa ocorreu entre dezembro de 2012 e maio de 2014 e será descrita nesta seção do capítulo, seguida pela apresentação dos principais resultados obtidos.

Inicialmente as entrevistas foram planejadas para ocorrer de forma presencial. Todos os encontros realizados desta forma foram riquíssimos em termos de conteúdo. No entanto, a opção de adotar, complementarmente, a modalidade de entrevista mediada, ou seja, virtual, aumentou sobremaneira as chances de colaboração por parte dos participantes em relação a esta pesquisa, pois, ofereceu ao entrevistado o poder de decisão sobre como seria sua forma de participação no estudo. Complementarmente, observou-se que:

Na medida em que as tecnologias de informação e comunicação baseadas na Internet transformaram a sociedade, elas transformaram, também, a disciplina da Sociologia. De forma mais geral, estas tecnologias alteraram a forma como cientistas e acadêmicos de todas as áreas buscam e referenciam informação relevante, inclusive a literatura acadêmica. Além disso, abordagens específicas à pesquisa sociológica também se transformaram. Os exemplos discutidos nas seções anteriores incluem pesquisa através de surveys, entrevistas face a face e métodos experimentais. (WITTE, 2012). ${ }^{59}$

De fato, a partir do momento em que essa estratégia foi adotada, possibilitando o participante de escolher a forma pela qual concederia a entrevista, mais agendamentos foram realizados, ampliando, inclusive o corpus empírico da pesquisa, pois permitiu que a

\footnotetext{
${ }^{59}$ Professor de Sociologia e Diretor do Center for Social Science Research da George Mason University (Estados Unidos).
} 
entrevistadora pudesse contar com a colaboração, a distância, de imigrantes e descendentes residentes em outras cidades brasileiras.

\subsubsection{Dados gerais sobre as entrevistas e sobre as visitas de campo}

Ao todo para esta pesquisa, foram realizadas 28 entrevistas em profundidade, em que os participantes contaram as histórias de suas famílias, como chegaram ao Brasil, principais dificuldades encontradas, quais mecanismos de preservação de identidade eram adotados (quando eram) e como essas pessoas se sentiam parte de uma chamada “comunidade árabe”. Ademais, entre 2011 e 2014, visitou-se sistematicamente espaços reconhecidamente frequentados por árabes e descendentes no Distrito Federal, ainda que tenha sido difícil eleger aquele ou aqueles mais representativos.

Nas visitas de campo realizadas ao longo da pesquisa, foi possível estabelecer contatos, conversas e informações com muitos imigrantes e descendentes, especialmente sírios e libaneses, mas também palestinos, egípcios e argelinos. Esses encontros ocorreram em restaurantes de comida árabe, exposições, espetáculos de música e dança árabe ocorridos na Capital Federal entre 2011 e 2014, contato frequente com membros da Federação das Entidades Americano-Árabes (Fearab Brasil e Fearab América), Instituto de Cultura Árabe (ICArabe em São Paulo), Biblioteca/Centro de Pesquisa América do Sul Países Árabes (BibliASPA SP), além de visitas à Rua 25 de Março em São Paulo (realizadas em 2011 e 2012). Importantes espaços religiosos e culturais para a comunidade árabe na capital federal foram contemplados, a saber: a Igreja Ortodoxa São Jorge, situada no Lago Sul; a Mussala (sala de orações) Muhammad, O Mensageiro de Deus, localizada em Taguatinga, e o Instituto de Cultura Árabe de Brasília, localizado na 706 Norte (Brasília-DF). 


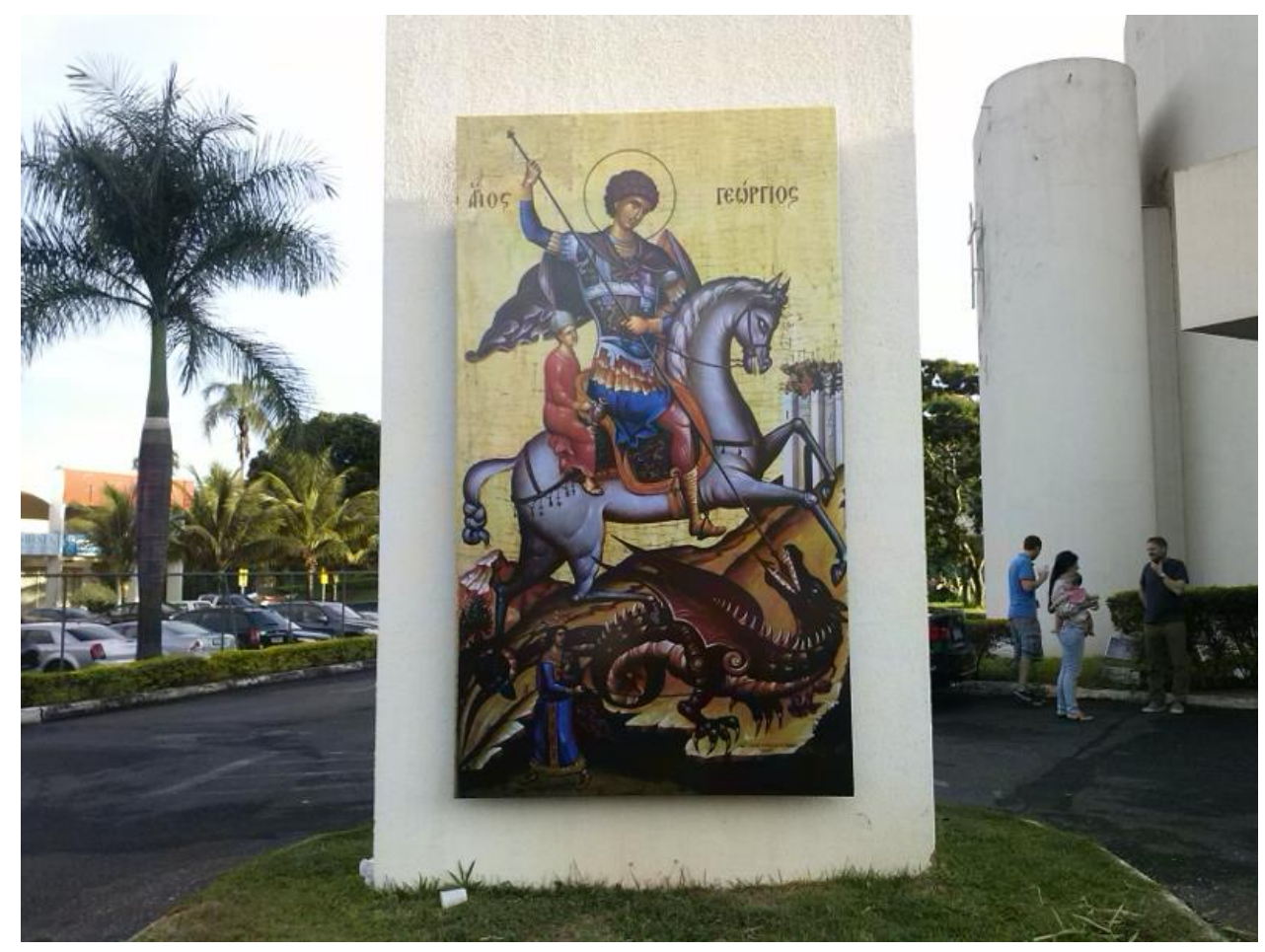

Figura 25 - Detalhe do exterior da Igreja Ortodoxa São Jorge em Brasília - DF

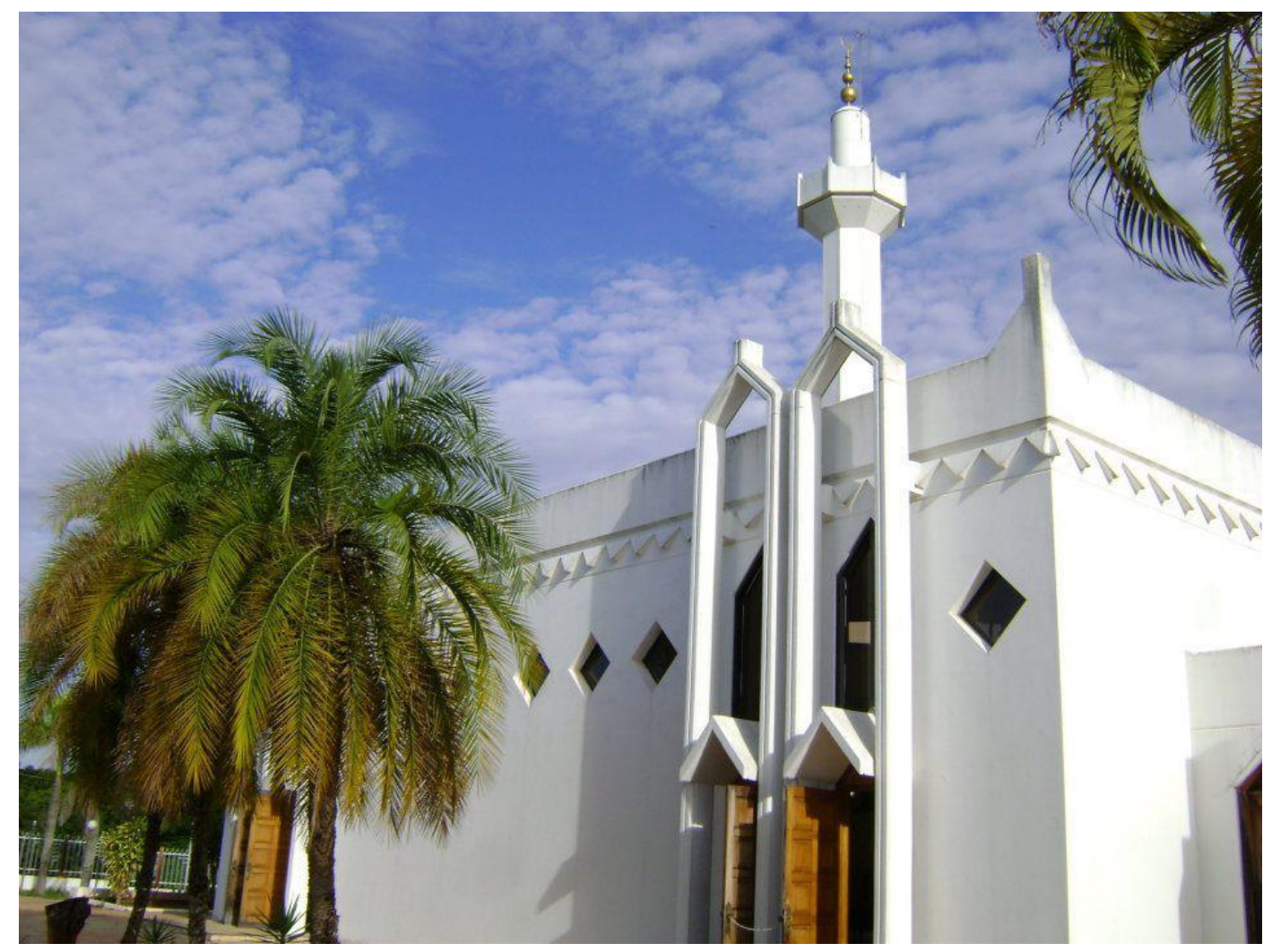

Figura 26 - Mesquita do Centro Islâmico do Brasil em Brasília - DF 
Sobre as entrevistas, cabe ressaltar que seis delas foram realizadas na modalidade face a face (com duração média de 70 a 90 minutos) em Brasília, e 22 na modalidade mediada (dez delas por meio de um programa de conversa em tempo real chamado Skype, e doze por meio de um questionário estruturado $)^{60}$.

Uma das entrevistas mais detalhadas foi feita com um libanês que veio para o Brasil ainda jovem com toda sua família, deixando o país no meio da guerra civil que se instaurou entre 1975 e 1990 (foram para Juiz de Fora - MG, onde permanecem até hoje) e atualmente é uma referência nacional na divulgação e promoção da dança árabe no Brasil. Outro libanês entrevistado reside em Foz do Iguaçu e é um dos organizadores da União Jovem Árabe Brasileira. Foram também entrevistados sete filhos de imigrantes (três do Líbano, três da Síria e um da Palestina) e 12 netos de sírios e libaneses.

Por localidade de residência, os participantes das entrevistas moravam nos seguintes estados:

- Distrito Federal (onze pessoas)

- São Paulo (sete pessoas)

- Rio de Janeiro (três pessoas)

- Minas Gerais (três pessoas)

- Paraná (duas pessoas)

- Goiás (duas pessoas)

Das oito pessoas que não possuíam ascendência árabe direta e que participaram da pesquisa, seis delas fazem parte do grupo de voluntários que participaram da etapa

60 Merece menção o fato de que 11 entrevistados foram pessoas que haviam colaborado na etapa experimental do projeto enviando fotografias de exemplos de presenças árabes na cultura brasileira. Das outras 17 pessoas entrevistadas, seis delas foram contatadas após indicações de conhecidos, e as outras 11 se voluntariaram por meio da página Presença Árabe no Brasil, criada na rede social Facebook com dois intuitos: (i) divulgar a pesquisa; e (ii) fazer uso de uma técnica recente de levantamento de dados intitulada observação participante virtual, e que será melhor detalhada adiante. 
exploratória do estudo por meio do envio de fotografias e que foram contatados para participar da segunda etapa de aprofundamento dos dados.

Os outros dois participantes que concederam entrevistas e que não eram de origem árabe foram contatados em razão de ambos possuírem uma relação bastante próxima com essa cultura no Distrito Federal. Uma dessas pessoas era o responsável pela Mussala de Taguatinga ${ }^{61}$ - DF (sala de orações muçulmana). A outra era uma bailarina que trabalha profissionalmente como professora de dança do ventre e desenvolve um projeto de ensino sobre a cultura árabe em uma escola pública do Distrito Federal.

As entrevistas face a face ocorreram em Brasília - DF, e foram realizadas de forma semiestruturada, tendo sido adotado um pequeno conjunto de perguntas no início da conversa e apenas algumas interferências por parte da pesquisadora conforme ia surgindo a necessidade de retomar algum aspecto importante durante a conversa. Ao todo, 11 pessoas entrevistadas em profundidade residem em Brasília. Porém, o número de imigrantes e descendentes contatados foi consideravelmente superior a este, pois ao longo de toda a investigação, manteve-se uma rotina intensa de visitas a estabelecimentos com maiores probabilidades de observar e conversar com pessoas relevantes para agregar o maior número possível de informações para a pesquisa. As visitas de campo foram em locais conhecidos como possuidores de uma forte presença árabe em Brasília.

\subsubsection{Os pontos em comum observados nas famílias de origem árabe}

Os resultados obtidos durante a pesquisa de campo realizada - que inclui entrevistas feitas entre 2012 e 2014 e visitas a espaços e eventos sociais frequentados por árabes e descendentes - indicam que as narrativas das famílias de origem árabe, mesmo com suas particularidades, possuem aspectos em comum, os quais merecem destaque:

- A vinda ocasionada pela necessidade de deixar um país em conflito político ou religioso e a busca por novas oportunidades;

\footnotetext{
${ }^{61}$ Foi escolhida a Mussala de Taguatinga pra visitas de campo após algumas tentativas frustradas de contato com a Mesquita do Centro Islâmico de Brasília que fica situada na Entrequadra da 712 / 912 Norte.
} 
- A importância de familiares e/ou amigos que auxiliaram os imigrantes imediatamente após sua chegada ao Brasil;

- O comércio como uma das alternativas mais promissoras para os imigrantes recém-chegados;

- A existência de espaços sociais para encontros da comunidade árabe no Brasil;

- A dificuldade da prática do idioma árabe entre as famílias cristãs e sua manutenção entre as famílias muçulmanas;

- As diferentes percepções quanto à existência ou não de conflitos;

- A família, a religião e a alimentação como elementos impulsionadores para a preservação de identidades árabes no Brasil.

Da lista acima, os três primeiros tópicos foram abordados no item 3.1 desta tese, que trata dos aspectos históricos da imigração árabe para o Brasil. Já esta seção trará elementos de reflexão sobre as demais questões.

\section{a. Os espaços sociais}

Em estados brasileiros, onde a presença imigrante árabe é mais volumosa e, em alguns casos, ainda conta com fluxos migratórios recentes, por exemplo, Paraná, os mecanismos de sociabilidade têm sido preservados e reforçados de diversas maneiras. É fundamental ressaltar a quantidade Sociedades Beneficentes, Clubes e Associações e as atividades organizadas por essas entidades. Em São Paulo, há importantes institutos de pesquisa, difusão e investigação da cultura árabe, tais como a Biblioteca/Centro de Pesquisa América do Sul - Países Árabes BibliASPA, e o ICArabe - Instituto de Cultura Árabe em São Paulo.

Em 2010, a Câmara de Comércio Árabe-Brasileira (CCAB), também sediada em SP, divulgou a existência de planos para construção de um Centro Cultural Árabe ${ }^{62}$, nos

62 Publicado em 15 de julho de 2010 pelo jornal $O$ Estadão. Disponível em : http://www.estadao.com.br/noticias/geral,comunidade-arabe-planeja-centro-cultural-em-sao-paulo,581779. Acesso em: ago. 2014. 
moldes do Instituto do Mundo Árabe (IMA) ${ }^{63}$, na França, e a Casa Árabe ${ }^{64}$, na Espanha. No entanto, esse projeto ainda não foi implementado. Há também iniciativas para preservação da memória dessa comunidade, como, por exemplo, ocorre em Goiás. Lá, foi criado um projeto chamado Árabes no Centro-Oeste que, desde 2010, conta com um programa de televisão que é exibido em um canal de assinaturas e que apresenta entrevistas com imigrantes e descendentes ilustres na região. ${ }^{65}$

Dentre as diversas situações criadas para promover maior interação entre a comunidade árabe, em especial, a sírio-libanesa, nessas regiões, estão eventos sociais, como festas, apresentações, cursos e encontros. Em praticamente todos esses eventos a alimentação é um elemento central, como será dito adiante.

Observou-se a importância dos estabelecimentos alimentícios como lugares de afirmação da identidade da comunidade especialmente sírio-libanesa no Brasil. Por exemplo, nas conversas informais, e também nas entrevistas, não raro se falava sobre a importância desses espaços para a preservação da memória de suas famílias e a perpetuação de elementos construtores de suas identidades para as gerações futuras.

A abertura do restaurante se deu em função de uma necessidade de resgate da memória da nossa mãe, após ela ter falecido. (D.C, filha sírios, proprietária de um restaurante de comida árabe em Brasília - DF)

Em Brasília, notou-se que os espaços sociais são mais escassos para a comunidade árabe do que em outros estados, onde moram os demais participantes da pesquisa que deram seus depoimentos. Destacou-se o fato de que o Instituto de Cultura Árabe Brasileira, Icab, embora seja uma entidade com longa tradição no DF, esteja vivendo atualmente um período de pouca procura pelos cursos oferecidos, seja de idioma árabe, seja de dança do ventre. A explicação dada por algumas pessoas ligadas ao instituto

\footnotetext{
${ }^{63}$ www.imarabe.org

${ }^{64}$ www.casaarabe.es

65 Por meio do site oficial do projeto é possível conhecer mais sobre esta iniciativa. http://www.arabesnocentrooeste.com.br/home/br/
} 
é de que sua localização - na 706 norte - não atrai estudantes em horários de pico devido ao congestionamento e à falta de vagas, o que dificulta o fluxo de alunos durante a semana. $\mathrm{O}$ edifício onde funciona o Icab possui estilo arquitetônico árabe e também sedia a Federação de Entidades Árabe Brasileiras - Fearab Brasil. Em conversa com uma professora do Instituto, ela contou sobre a preocupação com o baixo número de alunos que frequentam o espaço, mas ponderou também o fato de que no Distrito Federal são muitas as escolas de dança do ventre, o que poderia influenciar nessa questão do baixo número de inscrições. Segundo ela, apesar dos poucos alunos, os eventos do Icab, realizados semestralmente, são sempre bastante frequentados.

No entanto, os restaurantes e comércios voltados para venda de alimentos associados a tradições árabes não param de crescer no DF. Quanto aos resultados reunidos durante esta etapa da pesquisa, cabe ressaltar que, em primeiro lugar, chamou atenção o crescente número de estabelecimentos comerciais de comida árabe em Brasília, muitos dos quais significam, para seus proprietários (e talvez menos para seus clientes), uma forma de resgate e de autodescoberta sobre suas raízes, muitos dos quais passam a retomar contato com familiares no exterior e com uma chamada "colônia árabe" na cidade. 


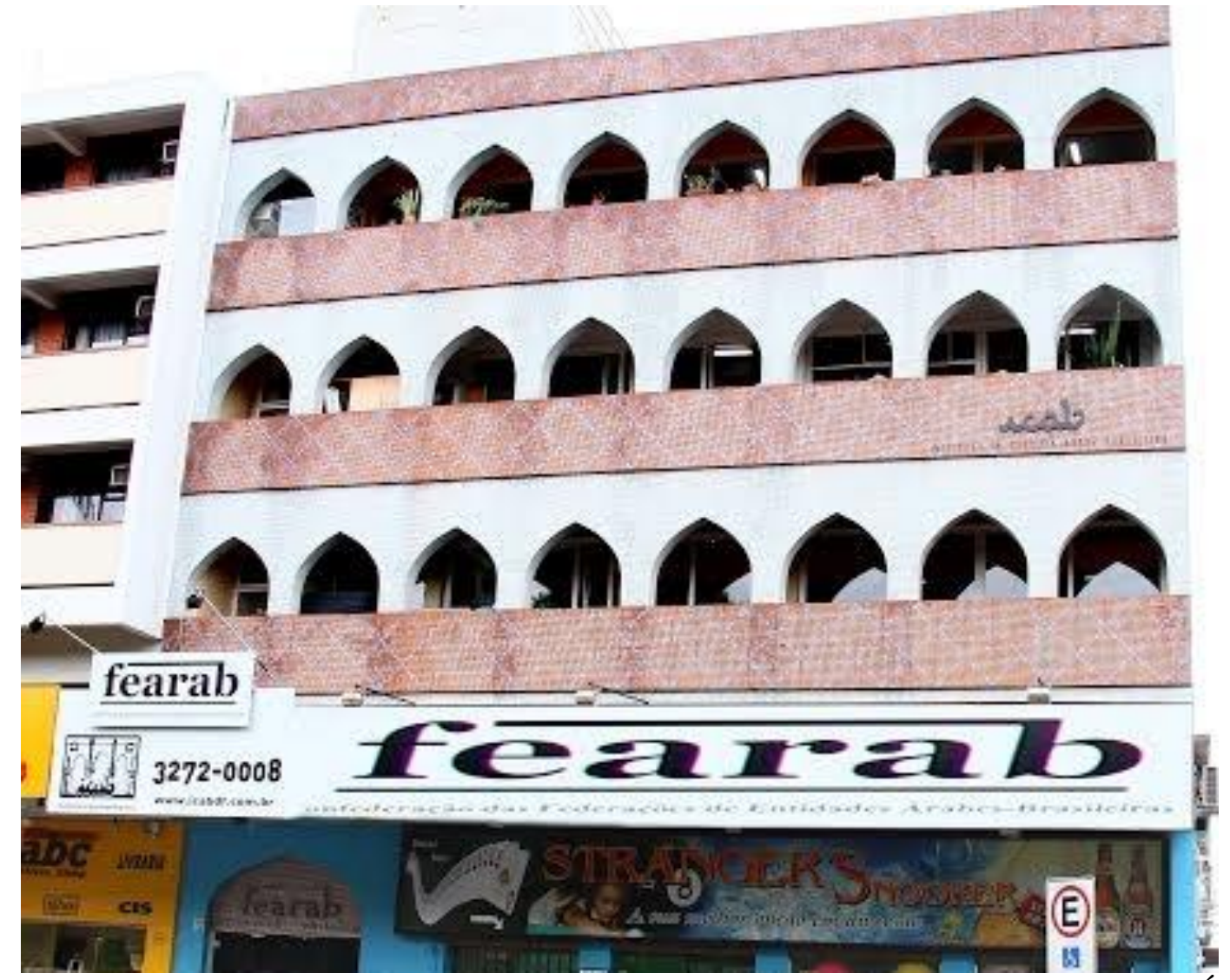

Figura 27 - Fachada do edifício onde está localizado o Instituto de Cultura Árabe Brasileira em Brasília - DF

Brasília, provavelmente por ser uma cidade nova e para a qual muitos árabes vieram após já estarem instalados no Brasil, convive com essa presença de forma um pouco diferente do que a pesquisa indicou por meio das entrevistas realizadas com pessoas residentes em São Paulo, Belo Horizonte, Anápolis e Rio de Janeiro e Juiz de Fora. Observou-se que o sentimento de pertencimento a uma "comunidade árabe" na Capital Federal está mais presente nas pessoas que possuem famílias já instaladas no DF há pelo menos mais de 30 anos.

Aqui em Brasília a gente conhece muita gente. É muito forte a colônia. A imagem de colônia na minha cabeça é essa agregação deles. Ele fala que tem mais libaneses fora do Líbano do que no país, né? Pode até não conhecer, mas você vê que a pessoa fala a língua e ele vai lá conversar. Isso era o que acontecia nos restaurantes dele também. Às vezes as pessoas não se conhecem, mas sabem que são árabes e se aglomeram. 
Meu pai não tem mais restaurante, está aposentado. Mas quase todo dia praticamente ele sai para tomar um cafezinho, no Lago, todos os árabes se conhecem lá. Ele vai lá na catedral São Jorge, alguns domingos tem almoço, tem dança.... (S. M.S., filha de libanês. Seu pai, agora aposentado, foi proprietário de três importantes restaurantes árabes na Capital Federal)

De acordo com entrevistados residentes em outras cidades, existe uma tradição de se referir à comunidade árabe como "colônia sírio-libanesa" (às vezes apenas libanesa, em outras ocasiões, síria).

A "colônia" é um termo que eu escuto desde criança (e sempre achei lindo, diga-se de passagem, porque dá justamente essa ideia de "comunidade", pessoas que se mantêm unidas!). Aqui existe o Esporte Clube Sírio de Belo Horizonte, que é o "nosso". E existe o Sírio-Libanês, que eu só conheço de nome. Quando eu era pequena, íamos ao Clube praticamente todo final de semana, e lá estava praticamente toda a família, desde as tias mais velhas, que ficavam jogando baralho, até as primas da minha mãe com as respectivas famílias. As festas que aconteciam (festival de caldos...) aconteciam sempre no clube, que era o ponto de encontro e comunhão da família. . (E.S. neta de sírios, residente em Belo Horizonte - MG)

Entretanto, houve quem alegasse não perceber esse discurso da "colônia árabe" em suas cidades, ou, nos casos em que essa expressão foi utilizada, a "colônia" foi citada, notou-se uma certa nostalgia, como se houvesse referência a um convívio que já não se observa com a mesma força que antes.

A adesão foi muito boa, na região. Tanto que não se fala em colônia. As pessoas não se sentem separadas. Claro que em casamentos, eventos, as famílias árabes se sentavam junto. [...] Mas houve uma associação muito forte. Pelo contrário. Eu acho que naquela região, os árabes conseguiram acumular dinheiro como mascates, mas acho que o sucesso econômico de alguma forma ajudou no processo de associação com a cultura brasileira, 
com a integração. (GMP, neto de libaneses, atualmente residente em Brasília - DF)

A geração antiga tinha sim preocupação em preservar a origem síria e libanesa, pois em Juiz de Fora a comunidade é grande. Mas a nova não. É uma pena que a geração antiga está indo embora (T.N., libanês, residente em Juiz de Fora - MG)

Durante a pesquisa, houve certa dificuldade em encontrar na capital federal um local onde árabes pudessem se reunir ou ter como uma referência de encontro para eventos, datas comemorativas e outras ocasiões. O Clube Monte Líbano, que em outras décadas foi uma dessas referências de lazer para a "colônia sírio-libanesa", como costumam se referir, atraía muitos imigrantes e descendentes. No entanto, atualmente, há pouca atividade no local, o que, para alguns entrevistados e para pessoas com quem tive a oportunidade de conversar informalmente, é motivo de frustração.

O mesmo ocorre em cidades como Belo Horizonte e São Paulo, onde esses espaços, embora não tenham a mesma agenda que outrora, seguem sendo referências importantes para a convivência de imigrantes e descendentes.

No início, se minha compreensão de criança não está muito falha, existia uma certa "restrição" para ter cota no Clube, de forma que era difícil ter pessoas que não fossem descendentes ou estivessem ligadas à família. Atualmente, isso mudou bastante, várias pessoas de fora já frequentam o clube. Isso descaracterizou, ao meu ver, essa questão do "ponto de encontro". Minhas tias e meu núcleo familiar, por exemplo, não vamos mais ao clube com tanta frequência. (E.S. neta de sírios, residente em Belo Horizonte - MG)

Naquela época as famílias reuniam-se no Club Homs. Hoje já estamos bem distanciados e as gerações foram sucedendo-se. Temos o Clube Sírio, o Monte Líbano. São os maiores. Mas são frequentados por sócios por poucos vínculos com a cultura árabe. (J.G., filho de sírios, residente em São Paulo - SP) 
Contudo, há muitos descendentes de árabes e imigrantes que não se sentem parte "dessa" chamada "colônia árabe", especialmente em Brasília, embora não deixem de reconhecer elementos de "arabicidade" em suas identidades. São, primordialmente, pessoas que chegaram mais recentemente e ainda tentam criar laços com a própria cultura brasileira, ou que precisam se estabelecer financeiramente. Durante as visitas de campo, foi possível também encontrar muitas pessoas que, embora possuam ascendência árabe, alegaram desconhecer com exatidão a história de sua família e sabem pouco sobre a cultura do país de origem.

Se, por um lado, existem pessoas que não são providas de um tipo de sentimento de pertencimento a um determinado grupo social, por outro, há aquelas que se esforçam para dar início a atividades culturais que busquem difundir melhor a cultura árabe, indo além do que se repete sistematicamente na imprensa e na história recente, que foca quase que exclusivamente na questão sírio-libanesa. Observou-se que, por parte de muitas pessoas, existe uma grande vontade de criar possibilidades para que essa convivência entre imigrantes e descendentes se torne mais intensa no DF.

\section{b. A prática do idioma árabe}

De modo geral, até a década de 40 aproximadamente, as famílias árabes tinham o sonho de retornar às suas terras, e por isso havia uma preocupação muito grande em não esquecer a língua materna, em ensinar aos filhos aqui nascidos suas tradições, seus costumes, o idioma árabe. E por isso havia várias escolas e cursos que atendiam essa demanda. Quando essas famílias tentaram voltar aos seus países, porém não conseguiram, muitos não viam mais sentido em manter a língua e os costumes, pois teriam que se conformar em viver aqui. O número de escolas voltadas para a comunidade árabe começou a declinar.

Os árabes imigrantes, logo aprenderam a língua portuguesa, mesmo apesar das dificuldades. Uma vez que a maioria dos imigrantes se estabeleceu no comércio, o árabe tornava-se inviável e o português, fundamental para o sucesso dos negócios. Eles aprendiam a língua portuguesa graças ao contato com os fregueses e com a ajuda dos parentes e amigos que muitas vezes já estavam aqui. 
Foram muitas as tentativas em preservar o ensino da língua árabe, mas por volta de 1937, com as leis do governo Vargas que proibiam o uso da língua estrangeira nos estabelecimentos de ensino e imprensa, acabam por desativar-se aquelas escolas que vinham sobrevivendo após 1925. Já no segundo período da imigração árabe ao Brasil, que se deu entre 1946-1984, novos estímulos ao ensino da língua árabe são percebidos. Mas agora, o interesse vinha principalmente a partir de muçulmanos, preocupados em manter sua fé islâmica e estes receberam ajuda financeira por parte de vários Estados árabes.

Eu diria que na minha família tem situações um pouco diversas. A impressão que dá é que sabemos todos que somos filhos, netos de palestinos, todos apreciamos a comida. Entendemos algumas palavras de árabe. Ninguém aprendeu o árabe de maneira fluente. Porém, essa ligação afetiva, cultural, essa necessidade de se mantê-la eu não sinto em outras pessoas da minha família. Mesmo em mim, ela só despontou em 2006. (AF, filho de palestinos, residente em Brasília - DF)

Muitas famílias, principalmente as cristãs, não tiveram a preocupação em preservar a língua árabe. Havia casos em que os pais preferiam manter a sua conversa íntima na sua língua original, e dessa forma os filhos não sabiam o que conversavam. Em algumas casas, há uma preocupação em ensinar o árabe aos filhos que aqui nasceram, para que eles não esqueçam suas origens.

Quando estão entre eles, em festas, ou na Mesquita, no caso dos muçulmanos, conversam todo o tempo em árabe. Há ainda, descendentes de imigrantes árabes que buscam aprender a língua por própria vontade, ou por uma preocupação com as raízes, ou por motivos religiosos, até mesmo por motivos comerciais.

Minha mãe falava um pouco, depois que a vovó morreu foi parando de falar. Eu estudei durante 3 anos, mas não falo. Acaba que não tem com quem praticar aí vai ficando enferrujado (risos). (P.M., neta de sírios, residente em Goiânia - GO) 
$\mathrm{Na}$ Capital Federal, como espaços que possibilitam a prática do idioma árabe, podemos citar o ICAB - Instituto de Cultura Árabe Brasileira, mencionado anteriormente, no item 4.2.1.. Lá, a cada semestre são iniciados novos cursos de árabe clássico e popular. Mas o interesse das pessoas em aprender tal língua ainda se restringe a descendentes de árabes, muçulmanos, acadêmicos ou profissionais atuantes em áreas em que o idioma é exigido. O Centro Islâmico de Brasília também passa por esse tipo de problema. Ao conversar com um professor, esse também me disse que quase ninguém mais hoje em dia tem interesse em aprender a língua árabe. E menos ainda em cursar as aulas ministradas no Centro Islâmico, o que ocasionou sua desativação.

\section{c. As diferentes percepções quanto à existência ou não de conflitos}

Ao serem questionadas sobre lembranças ou conhecimentos de episódios em família envolvido algum tipo de conflito causado pela sua origem, as pessoas entrevistadas afirmaram praticamente em sua totalidade que não se lembravam de nada relacionado a situações como esta. A grande maioria dos participantes da pesquisa alegou que, mesmo com as dificuldades da mudança e da instalação, a busca por um novo emprego ou criação de um negócio, era comum que se sentissem bem acolhidos e bem-vindos ao Brasil.

Recorrentemente foi citado o fato de que, ao deixarem sua pátria, os árabes procuravam escapar de situações de conflito, perseguições religiosas ou instabilidade política. E, provavelmente, devido ao fato de viverem situações extremamente delicadas em seus países, as dificuldades aqui encontradas não foram suficientemente graves para que as famílias imigrantes associassem o novo lar a situações negativas de preconceito.

Sou filho de uma palestina, de Haifa, nasceu em 1928. E meu pai, brasileiro, filho de palestinos. Vieram na década de 20 pro Brasil. Meu pai nunca foi à Palestina. E minha mãe nunca voltou. Das pessoas que vieram são, basicamente, minha mãe, tios, irmãos dela. Meus avós maternos vieram pra cá todos na mesma circunstância da Nakba. Antes de ir pro Brasil, passaram um tempo curto no Líbano, como refugiados, saindo daquela situação de 1948. Depois foram pra Síria, onde ficaram 3 anos trabalhando e morando na Síria. Uma situação ainda indefinida, porque acho que ainda havia uma expectativa de retorno. E depois, em 
1950, houve oportunidade de vir pro Brasil. Porque um parente já estava aqui e facilitou a vinda, a estadia, e o trabalho. Aqui eu tenho o bilhete da viagem, além de alguns documentos. Depois ficaram radicados em SP. (A.F., filho e neto de palestinos, residente em Brasília - DF)

Meu avô reclamava muito dos turcos. Ele dizia que em Yabrud o primeiro a beber água no bebedouro da praça era muçulmano, depois o seu cavalo, depois os cristãos. Mas o fato é que parentes dele já haviam emigrado antes e se tornado pequenos empreendedores em São Paulo. (J.B, neto de sírios, residente em Porto Alegre - RS)

Não sei de nenhum episódio de preconceito. Pelo contrário, o que contam é que eles fugiram de uma situação de preconceito e constrangimento em relação à dominação turca em seu país de origem. (M.D., neta e bisneta de sírios, residente em São Paulo - SP)

Um dos entrevistados lembrou-se de uma piada que escutava a respeito de seu avô, quando ainda era criança, de que ele seria uma pessoa avarenta. Mas, segundo ele, essa associação era mais relacionada ao fato de que ele era um homem que acabou se tornando bem-sucedido na cidade em que vivia, fato que incomodaria parte da população. Esse mesmo entrevistado fez questão de ressaltar que não qualificaria aquilo como discriminatório ou preconceituoso.

Preconceito nunca tivemos, mas já tivemos dificuldades sim com idioma, costumes e tal. (T. N., libanês, residente em Juiz de Fora - MG).

Meu bisavô paterno (T. C.) foi um dos primeiros imigrantes a vir de Homs, junto com Assad Abdalla e Nagib Salem. Eles logo perceberam várias lacunas em relação ao comércio e indústria daqui e procuraram inovar. Conseguiram se estabelecer muito bem, não sem bastante empenho, algumas mudanças de cidade e área de trabalho. Por terem sido os primeiros, era comum eu os outros imigrantes viesse se aconselhar com eles, sobre negócios, região para morar etc. Não sei de nenhum 
episódio de preconceito, pelo contrário, o que contam é que eles fugiram de uma situação de preconceito e constrangimento em relação à dominação turca em seu país de origem. (M. D., neta de sírios, residente em São Paulo - SP)

Ainda sobre essa questão, cabe aqui mencionar que muitos participantes da pesquisa reforçaram o fato de que, quando seus familiares chegaram ao Brasil, era comum já haver parentes, amigos e conhecidos que ajudavam no processo de adaptação e que, segundo os entrevistados, provavelmente este apoio contribuía para evitar algum tipo de sentimento discriminatório. Um entrevistado comentou que, mesmo notando uma tendência por parte da mídia brasileira em difundir imagens preconceituosas sobre árabes e muçulmanos, e, ainda que algumas pessoas "não filtrem" essas informações de maneira cuidadosa, qualquer manifestação de discriminação no Brasil era pífia diante do que os árabes passam em países da Europa, por exemplo.

Talvez eu pense um pouco qual o futuro, como os meus filhos verão isso. Qual a imagem que eles vão guardar da cultura. Como eu guardei hoje, eu acho que não vou mais conseguir fazer o mesmo. Há um processo de diluição. Meu avô é muito preocupado com isso, com o sobrenome. Uma das minhas tias fica chateada quando meu avô tem esse pensamento. Até hoje ele fala isso e deixa minha tia brava. Preocupação em relação ao legado, ao nome e em qual futuro. Eu tenho muito orgulho das origens árabes e libanesas. Não conheço o Líbano, mas tenho uma visão um pouco paradisíaca. Meu avô sempre fala das montanhas, das oliveiras, do mar... um país que é liberal, essa visão quando perguntam do Líbano eu tento ressaltar isso. Primeiro que o árabe é diferente. Cada país tem suas diferenças. Eu não conheço ainda, mas tenho essa preocupação do preconceito da Europa, nos Estados Unidos... não sei se esse fato das pessoas quererem desassociar dos árabes é mais por proteção, e não vergonha. Acho que não se deve esconder suas origens, mas é uma preocupação. (G.P., neto de libaneses, residente em Brasília - DF) 
Em termos amplos, observou-se que para captar melhor as situações de preconceito e discriminação, seria necessária a realização de um estudo específico sobre o assunto, que permitisse qualificar melhor os níveis de conflito. Entretanto, cabe menção breve ao fato de que durante a realização dessa pesquisa, foi possível conhecer pessoas que, embora filhos ou netos de libaneses, preferem não se autointitularem árabes, e sim, fenícios. Verificou-se que este é um mecanismo de afirmação de identidade que busca, entre os libaneses, distanciarem-se da chamada "cultura árabe", valorizando a história antiga de seu país, o que, faz sentido se levarmos em consideração o fato de que no Líbano os cristãos compõem $40,5 \%$ da população e essa seria uma forma importante de estabelecer uma distinção cultural em relação aos muçulmanos $(59,5 \%) .{ }^{66}$

Somos o berço dos fenícios. Eu não me incomodo com isso. Na verdade, não somos árabes, pois nossa origem é fenícia. Mas a nossa terra é lá, e nossa cultura é árabe. Mas alguns não gostam de falar assim, pois acham que árabes são só muçulmanos. Isso sempre existiu. Quem é fanático com a religião, fala que não é árabe (risos). Eu tenho orgulho de falar que sou árabe. (T.N., libanês, residente em Juiz de Fora - MG)

As entrevistas não tiveram o intuito de aprofundar a questão relacionada ao conflito, mas apenas averiguar como árabes e descendentes se sentem em relação a essa questão. Em conversas com árabes e descendentes, li e escutei relatos e depoimentos bastante parecidos uns com os outros sobre o tipo de preconceito que sofrem por sua religião, e muitas vezes pela confusão que as pessoas fazem com relação às religiões, não discernindo islamismo, de cristianismo greco-ortodoxo, ou outros. Entretanto, todos são unânimes em dizer que o preconceito vivido no Brasil está longe de ser parecido com o experimentado em outros países, onde conflitos abertos foram vivenciados nas últimas décadas, como é o caso da França, Estados Unidos, Espanha, Holanda, entre outros.

${ }^{66}$ A Constituição Libanesa reconhece oficialmente a existência de 18 grupos religiosos no país. Disponível em: https://www.princeton.edu/ achaney/tmve/wiki100k/docs/Demographics_of_Lebanon.html 


\section{d. Elementos impulsionadores para a preservação de identidades árabes no Brasil}

A família é um aspecto muito importante para a maioria dos árabes. Eles veem a família como pilar fundamental em suas vidas. A família para o imigrante árabe tornouse um dos poucos laços culturais que o mantém próximo a seu povo. Quando chegam/chegaram ao Brasil, embora seja possível falar em um choque cultural, por um lado, chama atenção o rápido processo de instalação desses imigrantes. Muitos alegam que, por terem chegado para trabalhar em comércios, a necessidade de adaptação se faz ainda maior, pois precisam lidar com clientes brasileiros diariamente.

A importância da família para o árabe pode ser ilustrada com o próprio processo de imigração. As pessoas que imigravam geralmente eram ajudadas pelos parentes, estes lhe emprestavam dinheiro, e também cuidavam de suas famílias enquanto eles estivessem longe.

Um tio que já estava no Brasil. Ele tinha vindo e tinha sido recebido por um parente mais distante. A partir desse contato, esse tio veio. Ele foi fazendo sua vida e permitiu que ele trouxesse outras pessoas. Minha mãe, meus avós. Todos permaneceram aqui e ninguém voltou. Agora eu tenho contatos. Eu estabeleci. Eu sou a única pessoa da família que foi até a Palestina. Eu fui três vezes em circunstancias diferentes. (A.F., filho de palestinos, residente em Brasília - DF)

Meus bisavós maternos vieram da Síria, como a maioria, fugindo da guerra e procurando uma vida melhor. Primeiro veio meu bisavô Carlos Elias. Ele veio para Anápolis, onde já havia alguns tios. Minha bisavó ficou na Síria, gravida do primeiro filho deles, a minha tia-avó Samira. Minha bisavó conseguiu vir para o Brasil somente 13 anos depois, pois antes ele teve que trazer os irmãos homens, por causa da guerra. (P.M., bisneta de sírios, residente em Goiânia - GO)

A relação entre família e comércio, que tanto aparece na literatura acerca da imigração árabe no Brasil, foi recorrentemente reforçada pelos entrevistados. Segundo os 
filhos e netos de sírios e libaneses, o imigrante que chegava, trabalhava, juntava dinheiro e, posteriormente, mandava buscar pais e irmãos, ou esposa e filhos. Então eles vinham e já encontravam, dessa forma um pouco menos de dificuldade para se estabelecerem. Com o passar do tempo, eles juntavam mais dinheiro e quem quisesse se juntar a eles, poderia vir. Alguns, ao invés de trazer a família, mandavam dinheiro para que seus parentes no país de origem melhorassem seu padrão de vida. Portanto, embora, os sírios e libaneses imigrassem individualmente, ainda estavam sob o domínio da família grande e do sistema de parentela.

Meu avô mascateou durante os primeiros 25 ou 30 anos entre Rio de Janeiro e São Paulo. Também andou por Minas, São João del Rei. Tanto é que cada filho nasceu numa pequena cidade do Vale do Paraíba (foram sete filhos), sendo que somente os dois mais novos puderam estudar e se formar. Os outros ajudaram "na lojinha". Meu avô se radicou em Volta Redonda, já pelo início dos anos 60. Foi quando comprou seu apartamento na Av. Atlântica, no Leme e se aposentou. (J.B., neto de sírios, residente em Porto Alegre - RS)

Meu pai era assim tinha o comércio nas veias. Ele adorava sentar com os fregueses e contar suas historias. Infelizmente, meu pai ficou doente em 1996 e faleceu em 2002. Nesse período eu larguei o consultório para tomar frente com o meu irmão no negócio. O restaurante ficava num sobrado na Rua Comendador Abdo Schahin, na Região da 25 de março. Nossos fregueses (árabes) tradicionais atravessavam a cidade para almoçar conosco. Foram envelhecendo e morrendo. Fomos matéria em revistas e jornais. [...] Olha estou falando dele com vocês com os olhos cheios de lágrimas. Meu pai era uma pessoa simples, mas muito rico em sabedoria. (J.G., filho de sírios, residente em São Paulo - SP)

De acordo com Nunes (2000, p. 158), a organização da família sofreu mudanças que afetaram relativamente a cultura original dos imigrantes. Segundo ela, alterações na unidade familiar foram percebidas a partir de questões como moradia, função econômica e práticas matrimoniais. Antes coesa, essa unidade foi modificada. Se a primeira geração de 
imigrantes - ou seja, aqueles que nasceram na "pátria-mãe", vivia de acordo com as demandas da unidade familiar "no que diz respeito ao casamento arranjado e prematuro" e manteve a tradição de construir uma família numerosa, a partir da segunda geração nota-se o abandono de algumas práticas: casamentos prematuros tornaram-se algo raro, aumentou consideravelmente a união entre homens árabes com mulheres brasileiras (embora o contrário ainda não ocorresse na mesma proporção), e o número de filhos gerados diminuiu sensivelmente. Ademais, se antes a posição da mulher era reconhecidamente subordinada, essa característica também é profundamente alterada.

Talvez um dos maiores indícios dessa questão seja o fato de que antes era comum que as mulheres vivessem com a família de seus maridos. No Brasil, a partir da segunda geração, elas passaram a constituir suas próprias famílias. Ainda em relação a essa instituição, seu papel foi fundamental no processo de apoio a parentes que chegaram ao Brasil e sua integração à sociedade receptora.

Antigamente os árabes mantinham o costume de casar seus descendentes com árabes e, dessa forma, praticamente não se misturavam com os brasileiros. Talvez por orgulho de suas origens, ou por negócios, até mesmo por religião, visto que a mulher muçulmana não pode casar com um homem não muçulmano. Muitos árabes inclusive iam até seu país de origem para encontrar uma esposa e a traziam para o Brasil. Hoje em dia, ainda há quem deseje manter essa tradição. Isso é notado quando as pessoas se referem a Foz do Iguaçu, por exemplo, considerado atualmente o maior ponto de atração de imigrantes muçulmanos xiitas. Muitos árabes ainda viajam para casar com uma mulher árabe, muitos fazem questão de casar com árabes ou filhos, ou netos de árabes. No entanto já é grande o número de descendentes que não seguiram esse caminho. Mesmo assim, a família ainda continua tendo um papel muito importante na vida do árabe.

Veja, a nossa colônia é muito aberta, você pode casar com quem quiser. É diferente de outras, como a armênia ou a judaica. Isso acaba transmitindo pouca cultura aos filhos. Talvez, o único ramo que ainda preserva alguma tradição seja o muçulmano. (JG, filho de sírios, residente em São Paulo $\mathrm{SP})$ 
Há outro detalhe importante na história das religiões das famílias migrantes. O fato de que muitos cristãos ortodoxos, muitas vezes, na dificuldade de encontrar igrejas ortodoxas no interior do país, preferiram assumir a fé romana, uma vez que as religiões não diferem muito uma da outra. No caso dos muçulmanos, a grande maioria permaneceu com a mesma religião desde que chegaram ao Brasil. Em algumas cidades, onde a presença muçulmana é alta, verifica-se a existência de antigas Sociedades Beneficentes Muçulmanas, Mesquitas, entre outros estabelecimentos. No Paraná, há escolas islâmicas, com ensino do idioma árabe oferecido na grade curricular. Nesse estado, há iniciativas curiosas, como, por exemplo, o projeto de Lei de autoria da vereadora Anice Gazzaoui aprovado em Foz do Iguaçu em 2013, que criou o Dia Municipal do Povo Muçulmano, a ser celebrado em 12 de maio de cada ano.

Vale acrescentar que São Paulo e Paraná concentram a maior parte dos muçulmanos residentes no país. Seguidos por Mato Grosso do Sul e Rio Grande do Sul. Essa população é fruto de imigração e, em grande parte, de descendência já nascida em solo brasileiro. Segundo a Federação Islâmica Brasileira, existem 1,5 milhão de seguidores do Islã no país. Acompanha a estatística, a existência de 50 mesquitas e mais de 80 centros islâmicos em solo nacional. 


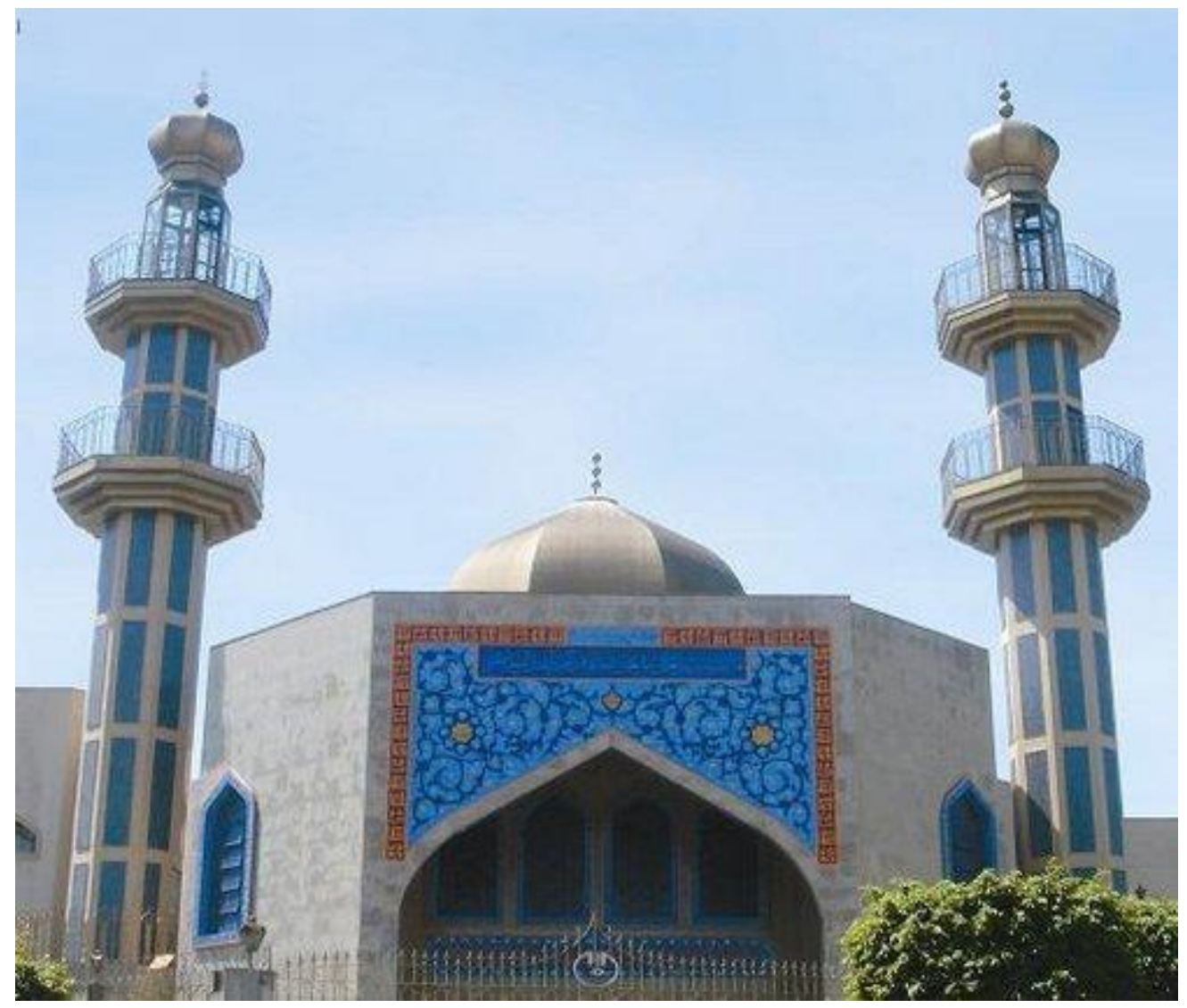

Figura 28 - Mesquita Mohammad Mensageiro de Deus (S.A.A.S.), também conhecida como Mesquita do Brás, situada em São Paulo (SP). ${ }^{67}$

Embora para algumas pessoas, a questão religiosa apresente alguma importância para explicar a convivência entre árabes e descendentes, especialmente no grupo formado por famílias muçulmanas, notou-se que em Brasília o aspecto religioso não possui tanta relevância quanto em outros estados. Isso ficou visível em conversas com cristãos ortodoxos e muçulmanos, bem como em visitas realizadas à Mesquita de Brasília e à Igreja Ortodoxa São Jorge, no Lago Sul.

Dentre os muçulmanos residentes no Distrito Federal, é possível destacar um grande número de pessoas ligadas às embaixadas de países onde o Islã é uma religião predominante, mas não são países necessariamente árabes. Há também imigrantes e

${ }^{67}$ Fotografia enviada por Mohamad Menem como colaboração ao Projeto Presença Árabe no Brasil em Imagens. 
descendentes, mas o número ainda é menor do que os frequentadores da Igreja Ortodoxa visitada.

Porque quem controla aquela mesquita é o governo saudita. Os árabes aqui em Brasília não estão muito ligados à religião. Estão mais ligados ao comércio. Olha a situação da mesquita. Eles colocam a culpa no governo da Arábia Saudita de que o governo não deixa fazer nada na mesquita. A mesquita tá ficando igual à outra. Porque em frente à mesquita nova tem a mais antiga. Ali tinha escola há alguns anos atrás. Está toda abandonada. Me disseram que o problema ali foi a guerra do Golfo. Os árabes se dividiram e a mesquita ficou abandonada. Mas ela praticamente está abandonada. Acaba que falam que essas representações diplomáticas aqui, ao invés de ajudar, acabam atrapalhando. Porque cada país dali tem um segmento. E cada um quer "puxar a sardinha" pro seu lado. Porque o problema da nossa mesquita aqui é mais política do que religião. Eu frequentava o Centro Islâmico de Brasília desde 1994, então eu já tenho uma história dentro do Islã. (J.E.H., muçulmano residente em Brasília DF, não possui ascendência árabe)

Observou-se, tanto pelas entrevistas em profundidade, pelos questionários respondidos e pelas visitas de campo, que, seja nos eventos sociais, nos encontros em família e em celebrações religiosas, os hábitos e tradições culinárias se destacaram como um importante componente aglutinador de sentimentos, em especial o de pertencimento (ou influência de) a uma cultura que, embora chamada de "árabe", muitas vezes reúne aspectos que não necessariamente são percebidos e apreendidos de forma uníssona pelos participantes da pesquisa.

Penso na Síria... Charuto, arroz com lentilha, coalhada... Nos doces que minha avó fazia... não sei bem o nome, mas aqueles com calda, feitos de macarrão com ricota... Sempre vou à 25 de março porque existem muitas casas árabes lá e compro um monte de coisas. (M. A., neta de sírios, residente em Rio de Janeiro - RJ) 
Preservaram as comidas, que sempre estiveram presentes em todas as casas da família. Todas as tias avós cozinham e a culinária árabe faz parte da vida cotidiana. Minhas tias também cozinham e minha mãe, atualmente, faz comida árabe para vender para fora. (E. S., neta de sírios, residente em Goiânia - GO)

Quibe, esfirra, tabule, coalhada. Minha mãe faz em casa. Toda semana tem coalhada. Eu trago pra cá. Zaatar, charuto, tanto de folha de uva quanto o de repolho. A sopa de coalhada, no inverno... E os doces... eu não sou bom de nome. Minha mãe cozinha muito bem. Ela é conhecida e reconhecida. Ela chegou a vender esfirras. Ela é famosa porque cozinha muito bem. O pistache, as especiarias, o azeite de oliva.... o chancliche, o pão sírio... Quando falo em comida árabe eu sempre penso no Líbano e na Síria. Confesso que só os dois. Não associo, por exemplo, ao Marrocos. (G.P., neto de libaneses, residente em Brasília - DF)

Eu até hoje preservo, pelo menos, a tradição árabe aqui em casa fazendo os pratos que aprendi com minha avó e tias. Sempre que vou a reuniões ou festinhas nas casas dos amigos, sou solicitada a levar os deliciosos pratos típicos da nossa culinária. O hommus bi tahine, os quibes e o pão árabe não podem faltar. (H.L., neta de árabes - não sabe dizer exatamente se sírios ou libaneses - residente no Rio de Janeiro - RJ)

A não ser pela questão dos hábitos alimentares, não sinto uma preservação da identidade cultural árabe em minha família. (F.L., neto de uma síria, residente em Ribeirão Preto - SP)

A relação entre alimentação, memória e identidade árabe no Brasil será melhor aprofundada no capítulo a seguir. Entretanto, antes de finalizar esta importante seção, é fundamental comentar que em Brasília, a partir de 2012, observou-se a inauguração de diversos restaurantes e lanchonetes de comida síria, muitos dos quais possuíam entre seus proprietários e funcionários, pessoas que deixaram o país em virtude dos conflitos civis em curso desde março de 2011 e que ainda não há previsão de término. Embora o governo 
brasileiro tenha reconhecido 284 sírios como refugiados em 2013, acredita-se que o número de imigrantes entrando no país extraoficialmente é muito maior. Em São Paulo, por exemplo, sabe-se que Associações Beneficentes Islâmicas tem envidado esforços para acolher essas pessoas, arrecadar bens e mantimentos para proporcionar-lhes condições mínimas e imediatas para se estabelecerem no país.

Não seria possível terminar a apresentação dos principais resultados coletados na etapa de entrevistas e visitas de campo sem acrescentar a observação de que o conflito sírio foi mencionado em algumas entrevistas, bem como durante as visitas de campo feitas pela autora, como responsável por haver criado, pela primeira vez no país, uma divisão clara entre os árabes e seus descendentes. Segundo alguns, isso jamais havia ocorrido no Brasil, e árabes de diferentes origens e religiões sempre conviveram muito bem, até então. Agora, segundo foi registrado por parte dos entrevistados, a comunidade árabe-brasileira se vê dividida em relação ao apoio ou não ao presidente Bashar al-Assad.

\title{
4.3 A observação participante em meio virtual: o uso das redes sociais como fonte empírica de dados para a pesquisa e a dinâmica da página Presença Árabe no Brasil
}

\begin{abstract}
A observação participante é uma modalidade de observação bastante empregada em estudos de natureza antropológica e sociológica e se distingue da observação sistemática pelo fato de esta última defender o distanciamento entre o observador e o fenômeno a ser observado, assim como a objetividade da observação, garantida pela adoção de procedimentos rigorosos de registros. (FRAZER \& GONDIM, 2004).
\end{abstract}

Além do levantamento exploratório realizado com imagens enviadas por colaboradores, das entrevistas presenciais em profundidade feitas em Brasília e com participantes de outras cidades por meio da modalidade mediada, dos questionários aplicados e das visitas de campo ocorridas em Brasília, a pesquisa contou também com uma importante interação em ambiente virtual, a qual permitiu aproximação da realidade de árabes e descendentes em diversas cidades brasileiras. 
Essa convivência, que aqui será chamada de "observação participante em meio virtual", também tem sido discutida em meio acadêmico como uma modalidade recente de pesquisa e recebe, de acordo com o enfoque dados por seus investigadores, distintos nomes, que vão desde etnografia virtual, termo adotado pela inglesa Cristina Hine (Virtual Ethnography, 2000), etnografia do ciberespaço, como Hakken (1999) prefere se referir, etnografia de/em/através da internet, expressão cunhada por Baulieau (2004), apenas para citar alguns.

A adaptação da metodologia etnográfica às especificidades dos fenômenos desenvolvidos em meio digital demanda um conjunto de reflexões acerca dos principais conceitos básicos e critérios metodológicos. A etnografia, tal como é usualmente realizada por antropólogos enquanto estratégia de pesquisa, conta com a presença massiva do investigador na população pesquisada de maneira a dividir uma mesma experiência social e, destarte, alcançar subsídios para estabelecer "diálogos entre o que vem sendo adquirido como suas bagagens teóricas a respeito da temática pesquisada, a sua reflexividade, que é inerente à condição de existir em qualquer lugar e/ou com qualquer pessoa". (ADAMI, 2008, p. 21)

\subsubsection{A escolha do espaço virtual para observação participante}

Nas últimas décadas, o advento da Internet trouxe consigo um novo campo de estudo para a Sociologia. Dentre os temas que passaram a despertar a atenção dos sociólogos estão as implicações sociais desta nova tecnologia, como novas formas de interação, comunidades virtuais, entre outros. Foi a partir da leitura de publicações voltadas para o estudo das relações sociais em ambiente virtual, em especial, aquelas produzidas por Manuel Castells (2004), que surgiu a ideia de abrir também uma frente de levantamento de dados para a pesquisa nessa direção.

Manuel Castells (1999, p. 498) define as redes de comunicação como conjuntos de nós interconectados, cuja topologia define as distâncias entre os usuários desses nós. O fluxo de informação entre eles, por sua vez, depende de uma hierarquia definida pela arquitetura da rede, que estabelece o trânsito dos dados no tempo e no espaço. São estruturas 
abertas que podem se expandir de forma ilimitada, desde que os usuários compartilhem os mesmos códigos de comunicação. Por isso, as redes implicam uma política interna, ou seja, uma distribuição de poder. As redes são criadas para diversas finalidades concretas, como circulação financeira e investimento de capitais, gestão política, sistemas de comunicação midiática, como rádio e televisão, formação de arquivos e acervos públicos e, também, tráfico de drogas e outras formas de organização social, como rebeliões e ativismo político. Como toda a sociedade se organiza através dessas redes, elas interferem diretamente na atuação e na ação concreta de toda a sociedade. Mas as chamadas redes sociais são redes especialmente criadas para a sociabilidade, para a interação entre pessoas nelas conectadas. De maneira geral, são programas de comunicação por computadores em que cada usuário se conecta a partir de um convite pessoal, preenchendo cadastro individual pelo qual traça um perfil de gostos, tendências, hábitos e informações pessoais; imagens, parentescos, participação institucional e interesses, que vão de relacionamentos afetivos a jogos e entretenimento. (REVISTA USP, 2011-2012, p. 86-99).

André Telles, autor do livro A Revolução das Mídias Sociais (2010) chamou a atenção para o fato de que, no Brasil, mais de $80 \%$ dos internautas, ou seja, pessoas que costumam "navegar” pela internet, participam de alguma mídia social. Segundo ele:

Os sites de relacionamento ou redes sociais são ambientes que focam reunir pessoas, os chamados membros, que uma vez inscritos, podem expor seu perfil com dados como fotos pessoas, textos, mensagens e vídeos, além de interagir com outros membros, criando listas de amigos e comunidades". ${ }^{68}$ (TELLES, 2010)

68. Disponível em: http://www1.folha.uol.com.br/tec/2012/10/1163808-facebook-mostra-o-raio-X-de-1bilhao-de-usuarios.shtml. Acesso em: set. 2014. 
Durante toda realização do estudo houve contato com árabes, descendentes e admiradores da "cultura árabe" por meio de um ambiente virtual propiciado por meio da criação de uma página em uma rede social que tem se revelado importante nos últimos anos, o Facebook. ${ }^{69}$ Esse espaço virtual serviu de laboratório de pesquisa, além de um grande centro de convivência com pessoas de diferentes países, cidades e origens, que participaram ativamente de uma dinâmica de publicações diárias na página Presença Árabe no Brasil e que contribuíram enormemente para a captação de informações que adiante serão apresentadas e analisadas.

Em novembro de 2011, com o intuito de difundir o projeto Presença Árabe no Brasil em Imagens, já apresentado, decidiu-se que a melhor forma de colocar em prática essa proposta seria por meio de um ambiente virtual, que permitisse o contato com pessoas que estivessem fora de Brasília, mas que pudessem contribuir com o estudo. Nesse sentido, após observar as opções disponíveis à época para realização desse recurso eletrônico de levantamento de informações e depoimentos a serem captados para a pesquisa, a criação de uma página em uma rede social pareceu a melhor saída para dar início a essa etapa da pesquisa.

O primeiro passo para colocar em prática esse projeto foi a criação de uma página com o mesmo nome do site inaugurado para receber as fotos que viriam a delimitar a primeira fase - exploratória - desse estudo. A página Presença Árabe no Brasil foi inaugurada na mesma semana que o site Presença Árabe no Brasil em Imagens e o intuito, com a seguinte descrição:

\footnotetext{
${ }^{69}$ Criado em 2004, este é um dos sites de relacionamento mais populares entre os internautas e, desde 2012 superou a marca de um bilhão de usuários ativos.
} 
A palavra "árabe", embora simples, carrega um conjunto de significados e representações sociais. Ela é compreendida a partir de diversos pontos de vista, tais como o geográfico, o linguístico e o histórico. Mas também, e muitas vezes, é associada a assuntos religiosos e políticos. De forma resumida, pode-se dizer que o termo 'árabe' é associado a uma região particular do mundo. Quase todas as pessoas na região que se estende desde a Costa Atlântica do Norte da África até o Golfo Pérsico se auto intitulam árabes. A classificação é baseada largamente em um idioma comum (árabe) e o compartilhamento de um senso de identidade geográfica, histórica e cultural. Porém, isso não quer dizer que uma família árabe em Beirute, capital do Líbano, possua, por exemplo, os mesmos hábitos de uma família em Túnis, capital da Tunísia, seja em termos de sua alimentação, vestuário ou comportamentos. Além do mais, na maioria das vezes é recorrente encontrar generalizações e confusões em torno da palavra "árabe". Partindo da premissa de que estamos falando de uma presença árabe plural, ou melhor, de variadas presenças árabes no Brasil, esta página foi criada como parte integrante de um projeto relacionado à minha pesquisa de doutorado. Convido todas as pessoas que desejarem colaborar com este estudo a enviarem fotos (preferencialmente até 3 imagens) que considerem EXEMPLOS DA PRESENÇA ÁRABE NO BRASIL. Pedimos que as fotos sejam de autoria do/a participante, ou que sejam fotos próprias (por exemplo, de família). Neste sentido, será criada uma base de imagens que ficará disponível no site e que será alimentada durante um período determinado.

Quadro 3 - Texto de abertura da página Presença Árabe no Brasil, no Facebook

Em 06 de janeiro de 2014, passados mais de 24 meses desde a criação da página no Facebook, o número de pessoas inscritas havia ultrapassado as 5.200, como mostra imagem a seguir. 


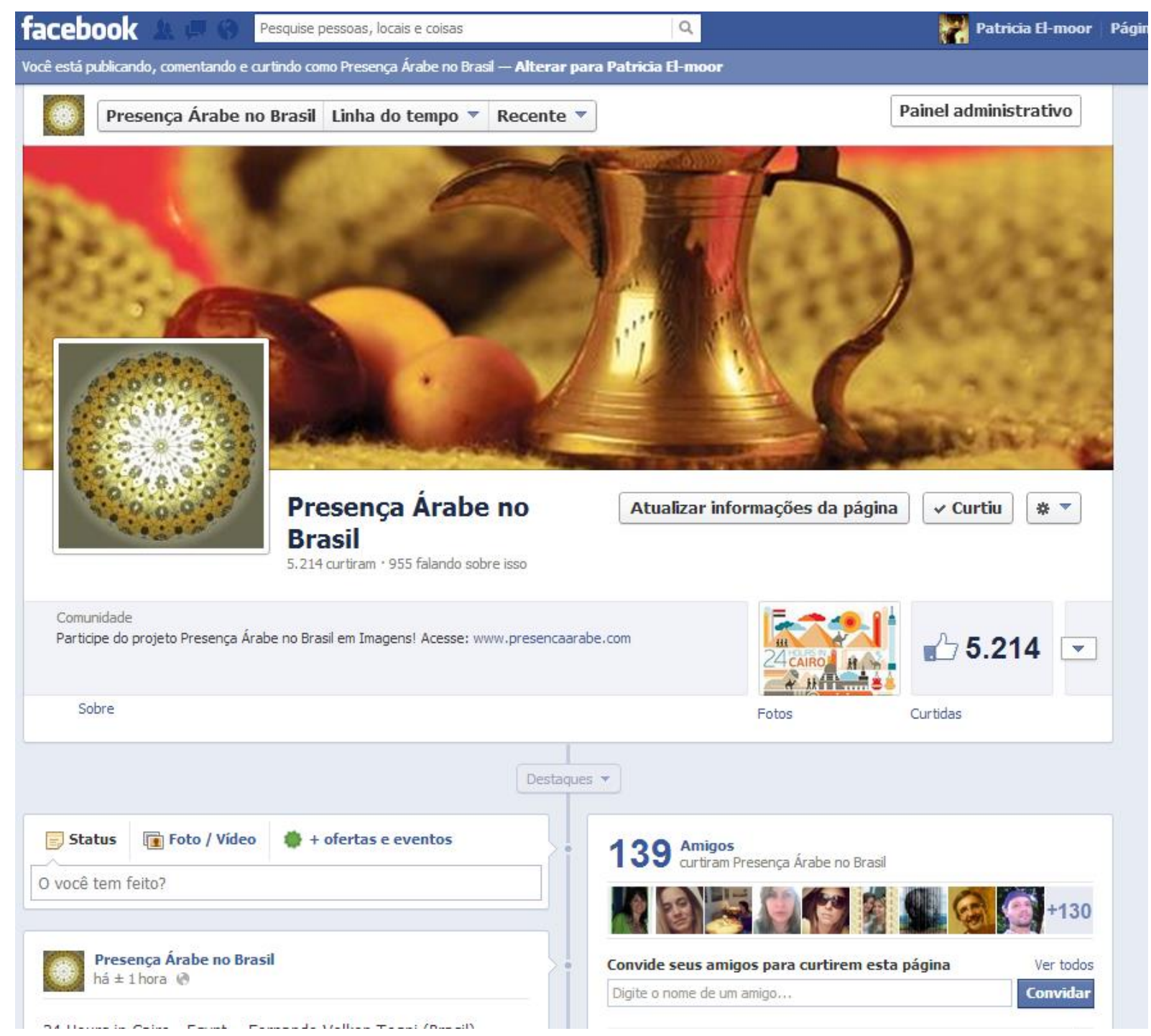

Figura 29 - Tela principal da página Presença Árabe no Brasil no Facebook

Do total de 5.214 pessoas que acompanhavam a página nessa data, é possível observar que apenas 139 se caracterizam como conhecidos ou amigos da autora, o que representam 2,6\% dos participantes. Este número de seguidores virtuais - ou seja, usuários do Facebook que, após clicarem na opção "curtir” a página, passam a receber suas atualizações por meio de notificações no próprio Facebook - foi alcançado por meio de um exercício diário e constante de publicações rotineiras na comunidade virtual, as quais variavam em torno de um conjunto de temas, em especial, notícias diárias sobre mundo árabe e cultura árabe. 
Houve momentos durante esse processo em que a página foi citada por outros pesquisadores, o que contribuiu fortemente para a sua divulgação. Também, ao longo desse processo, a autora pode contatar e consultar diversas entidades ligadas à difusão da cultura árabe no Brasil, a saber: Instituto de Cultura Árabe (Icarabe), em São Paulo; Biblioteca América do Sul - Países Árabes (BibliASPA) em São Paulo, Federação das Entidades Americano-Árabes (Fearab América), Federação das Entidades Árabes no Brasil (Fearab Brasil), entre outros.

\subsubsection{Assuntos que mais despertaram a participação social nas redes sociais durante a pesquisa de campo}

As publicações realizadas na página Presença Árabe no Brasil tinham o intuito de criar uma dinâmica no espaço virtual e captar as impressões de seus visitantes. Diariamente eram pesquisadas algumas notícias relacionadas ao mundo árabe por meio de um clipping diário configurado por meio do Google Notícias, que selecionava sistematicamente as notícias de interesse a partir de palavras-chave por mim indicadas. Posteriormente, elas eram compartilhadas entre os leitores. Para a pesquisa, foram utilizadas as seguintes palavras-chave:

- Mundo Árabe, Árabes, Países Árabes, Cultura Árabe, Imigração Árabe,

- Além do nome de cada país atualmente compreendido como árabe pela Liga dos Países Árabes.

As principais fontes de informação eram provenientes na maior parte das vezes dos sites relacionados abaixo:

- Portal EBC (Empresa Brasil de Comunicação), Portal Terra Brasil, Portal UOL, Portal G1, Portal Estadão, outros.

Independente do clipping feito pelo Google Notícias, a autora também pesquisava notícias em outras fontes de informação, mais especializadas sobre o assunto e que receberão maior atenção adiante:

- Agência de Notícias Brasil-Árabe (ANBA)

- Instituto da Cultura Árabe (ICArabe) 
- Biblioteca/Centro de Pesquisa América do Sul - Países Árabes (BibliASPA)

Por fim, na página Presença Árabe no Brasil, além das principais notícias diárias publicadas nos jornais e portais de informação, a autora também adquiriu o costume de criar entre quatro e seis publicações com temas diversificados, que giravam em torno dos seguintes assuntos:

- Alimentação;

- Música;

- Referências bibliográficas sobre história e cultura árabe;

- Sinopses de filmes sobre mundo árabe;

- Representações nas artes plásticas sobre mundo árabe (Orientalismo);

- Literatura árabe; e, por fim;

- Indicações e recomendações compartilhadas pelos participantes da página, as quais eram enviadas em mensagens privadas.

Ocasionalmente, os participantes enviavam pedidos específicos, como ajuda para divulgar algum evento, uma pergunta sobre a grafia em árabe para determinada palavra ou dúvidas quanto a assuntos relacionados à política, haja vista as fortes e intensas mudanças vividas em diversos países a partir de 2011, o que ficou conhecido como "Primavera Árabe". As imagens a seguir ilustram algumas das situações diárias ocorridas na página: 


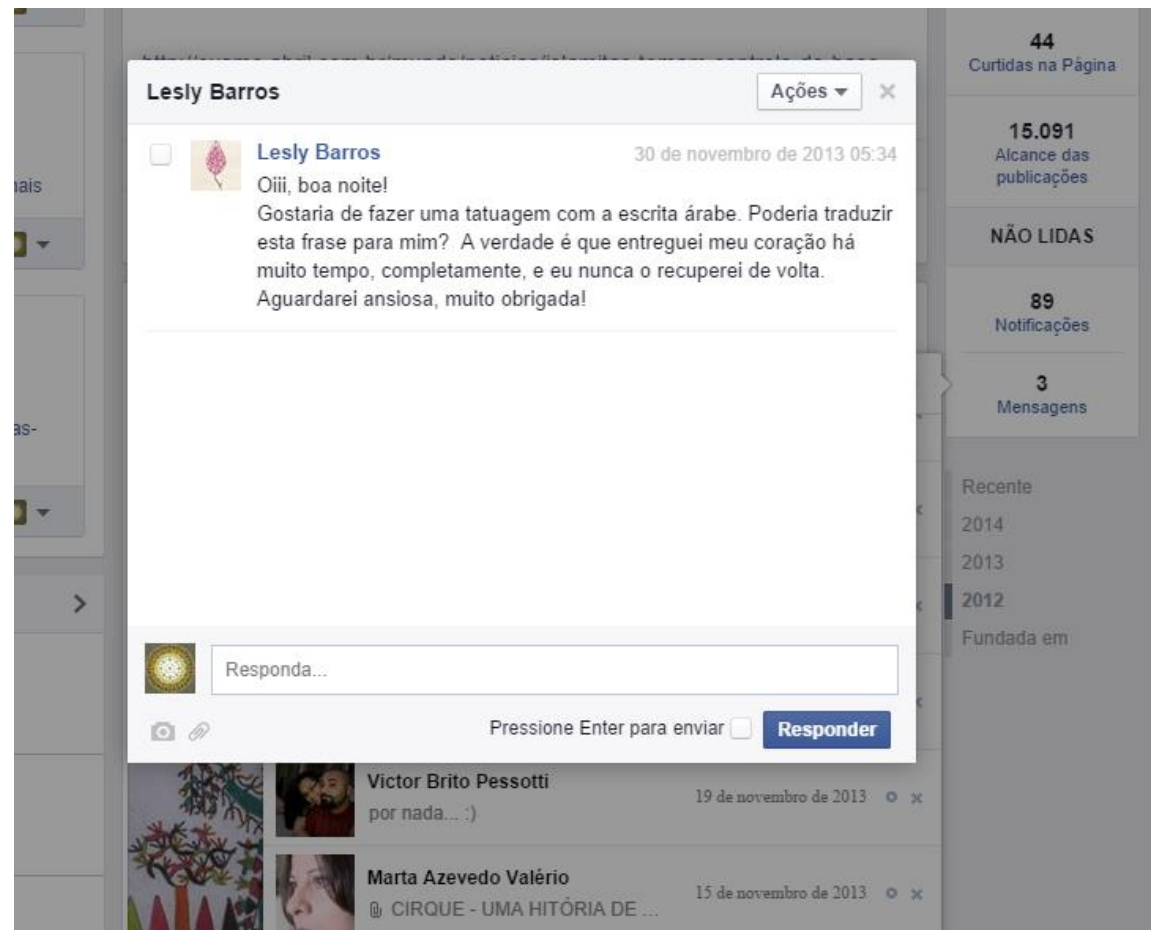

Figura 30 - Exemplo de uma mensagem privada por meio da página Presença Árabe no Brasil, no Facebook.

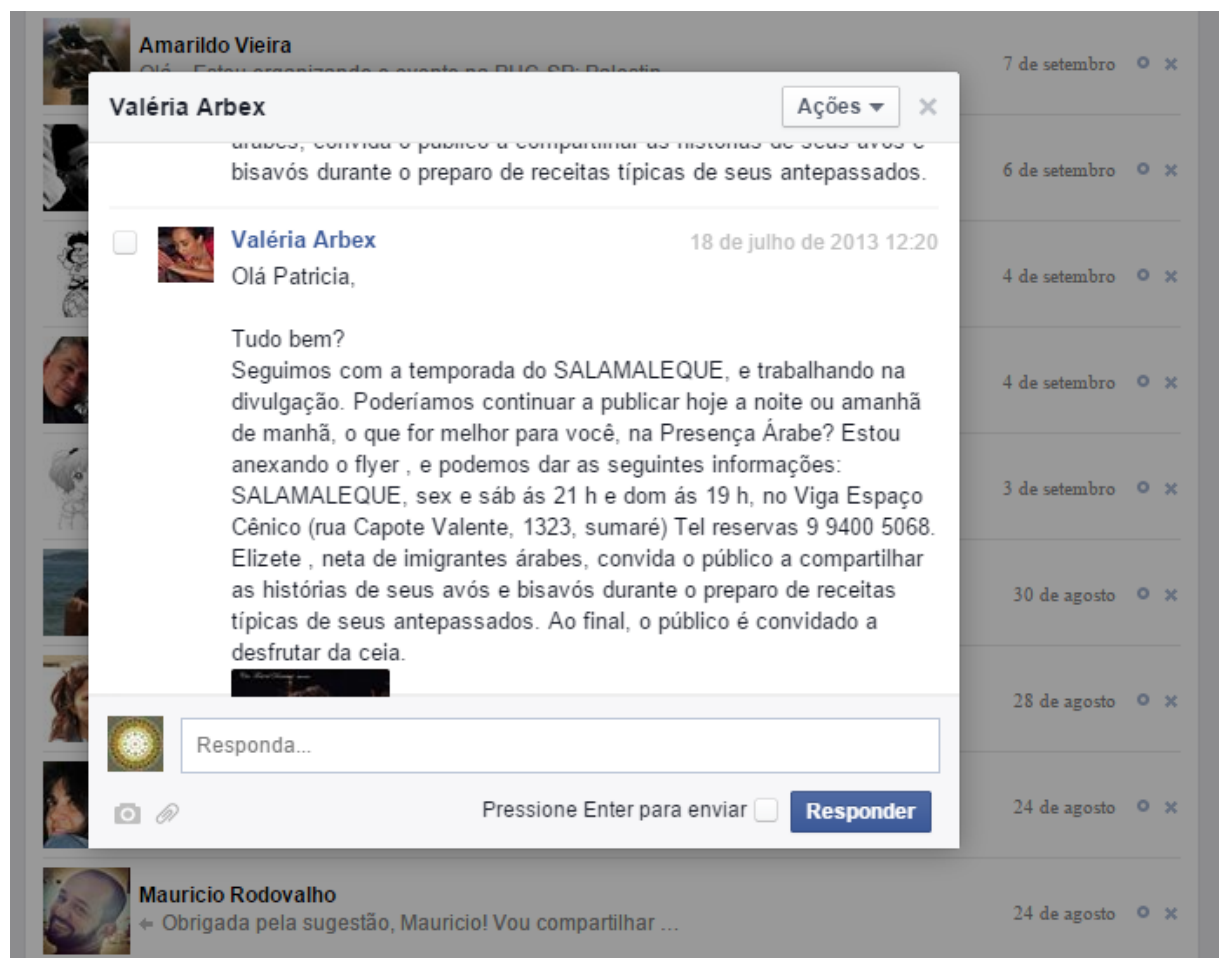


Figura 31 - Exemplo de uma mensagem privada por meio da página Presença Árabe no Brasil, no Facebook.

Esse esforço teve o intuito de estimular a participação das pessoas, as quais podiam deixar comentários e impressões, possibilitando, em última instância, a observação, que captaria o maior número de dados possíveis que indicassem como as múltiplas presenças árabes no Brasil são percebidas e representadas socialmente.

A experiência do projeto Presença Árabe no Brasil em um ambiente virtual foi fundamental durante todo o processo de pesquisa, por vários motivos. Em primeiro lugar, muito enriqueceu o conhecimento adquirido acerca do mundo árabe enquanto objeto (de pesquisa) heterogêneo e de difícil delimitação haja vista a enorme diferença de percepções e compreensões que giram em torno da palavra árabe. E ainda, permitiu que se mantivesse contato com pessoas de origem árabe, descendentes de imigrantes ou curiosas sobre a cultura ainda que elas estivessem em lugares distantes, como Foz do Iguaçu, Manaus, ou ainda, em outros países, tais como Líbano, Síria, Marrocos, Tunísia, Alemanha, França, entre outros. Esse contato diário, mais especificamente a observação constante dos comentários deixados na página, permitiu confirmar impressões que haviam sido feitas na época do recebimento dos questionários e da realização das entrevistas.

Merece destaque o fato de que situações de extrema importância surgiram a partir desse contato, com destaque para algumas mencionadas a seguir, e que possibilitaram maior aproximação junto à comunidade virtual observada cotidianamente entre 2011 e 2014. Primeiramente, essa experiência possibilitou uma maior proximidade com o Instituto de Cultura Árabe ICArabe e com a BibliASPA, ambas as organizações voltadas para a difusão da cultura árabe no Brasil e sediadas em São Paulo. Essa aproximação resultou em convites para participar de eventos relacionados à difusão da cultura árabe no Brasil, tais como cursos, festivais de cinema árabe, festivais culturais, entre outros.

Complementarmente, viabilizou maior contato com entidades ligadas à cultura árabe fora do eixo Rio-São Paulo, tais como a União Jovem Árabe Brasileira, sediada em Foz do Iguaçu; além de acadêmicos e pesquisadores brasileiros e estrangeiros dedicados a temas relacionados ao mundo árabe: cultura, política, relações internacionais, história etc. 
$\mathrm{O}$ ambiente virtual permitiu ainda verificar os temas e assuntos que mais despertavam interesse entre os leitores da página ao longo desses três anos, bem como verificar um ponto que se fez presente ao longo de toda a pesquisa, que trata da questão das manifestações de discriminação e preconceito, possivelmente sofridas pelas pessoas de ascendência árabe.

Dentre os temas que mais estimulavam a participação dos leitores na página, é possível mencionar a alimentação, a música, a literatura, o cinema, além de publicações sobre a imigração árabe no Brasil. Assuntos ligados à religião e à política, embora não passassem despercebidos, frequentemente eram comentados por visitantes com um perfil mais específico: participavam desses tópicos administradores de outras páginas no Facebook, muitas delas voltadas para tais temáticas. De fato, observou-se que a participação nessas publicações era mais restrita e, normalmente, carregada de grandes polêmicas.

As maiores controvérsias provocadas entre leitores da página ocorreram em torno de assuntos bastante pontuais. Os conflitos relacionados à questão palestina merecem ser mencionados, pois frequentemente eram motivo de muitas discussões. Neste caso, o debate era dotado de uma conotação política e religiosa muito forte, envolvendo manifestações contra e a favor do Estado de Israel, questionamentos quanto à legitimidade do partido Hamas, considerado por muitos como um grupo terrorista, entre outros temas polêmicos. Em determinadas situações específicas, quando se compartilhou alguma notícia relacionada à Palestina, a página recebeu muitos comentários e desabafos criticando o Estado de Israel e sua política de expansão de fronteiras, a qual vem prejudicando, de acordo com relatórios da Organização das Nações Unidas (ONU), milhares de palestinos. A imagem a seguir é apenas um exemplo, dentre tantos que podem ser observados na página, em publicações desde 2011. 


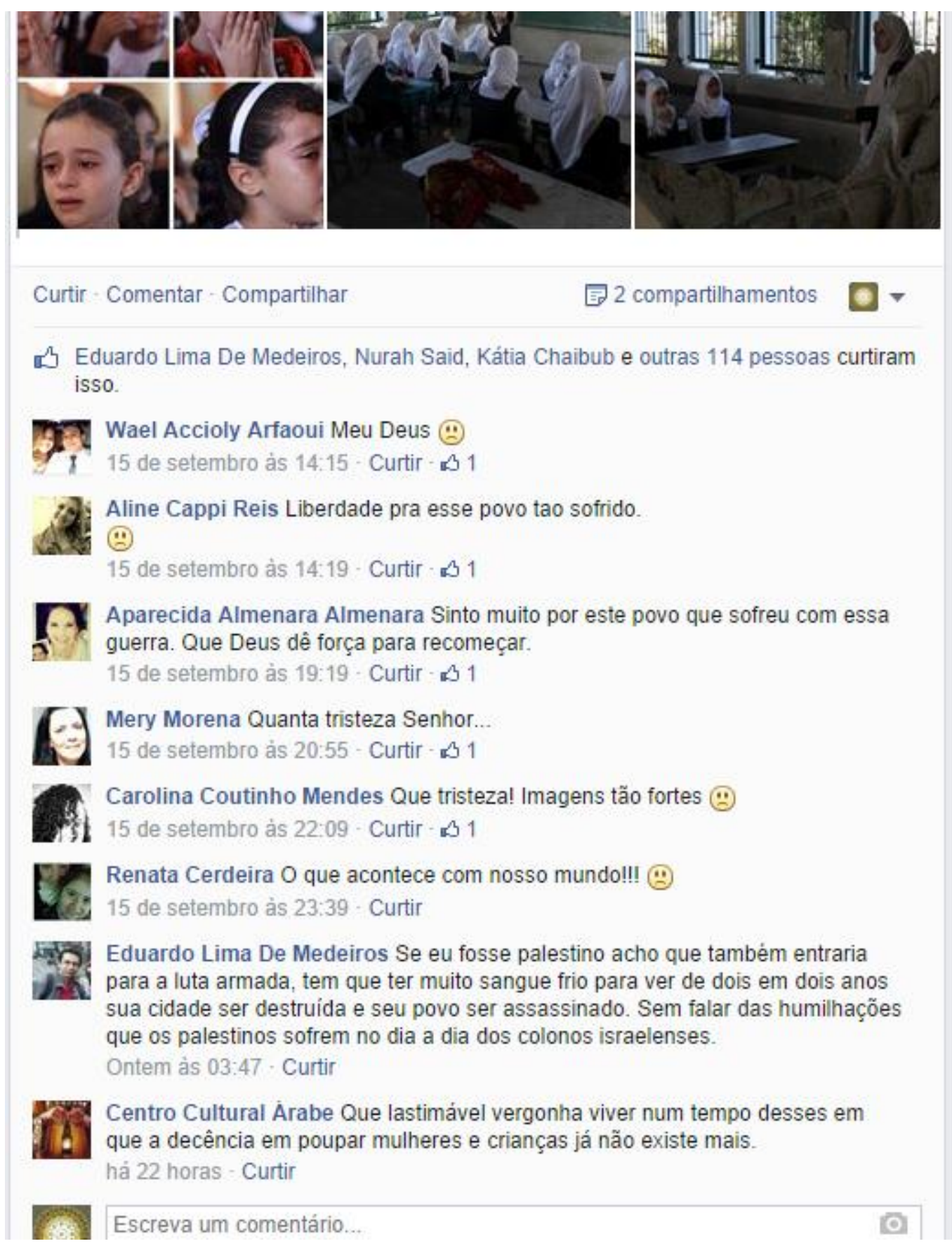

Figura 32 - Comentários deixados em uma publicação sobre a Palestina na página Presença Árabe no Brasil, no Facebook

O conflito desencadeado na Síria desde 2011 foi outro tema que mobilizou grande participação na página. Como já havia sido observado por parte de muitos entrevistados e participantes desta pesquisa, o mesmo se notou na página Presença Árabe no Brasil: uma cisão fortíssima entre a comunidade árabe, que se vê atualmente, dividida entre apoiadores 
do atual presidente e pessoas que se posicionam contra a política atual no país. Essa ruptura - inédita até então, segundo alguns participantes, tem repercutido de diversas maneiras no Brasil. ${ }^{70}$
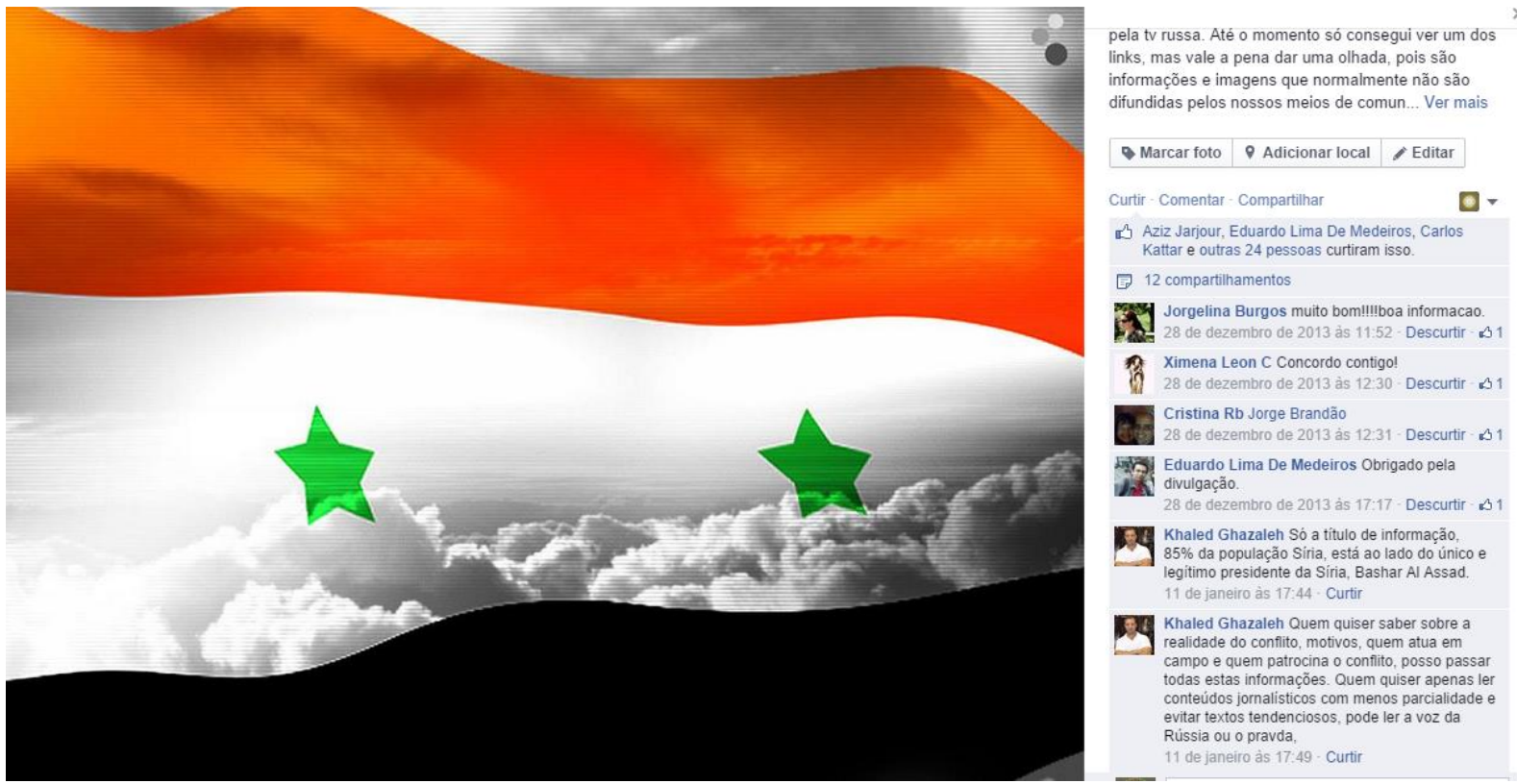

Figura 33 - Comentários deixados em uma publicação sobre a Síria na página Presença Árabe no Brasil, no Facebook

Por outro lado, notou-se que a questão da comida (árabe) era, dentre todos, o tema onde as pessoas mais se sentiam inclinadas a se manifestar, não importando se eram especialistas em temas ligados ao mundo árabe, parentes ou até mesmo, pessoas nascidas nesses países. As imagens apresentadas a seguir foram capturadas na página Presença Árabe no Brasil e incentivam algumas considerações importantes.

${ }^{70}$ Complementarmente, merece menção o fato de que muitos clubes e associações culturais estão com a programação de atividades reduzida há mais de dois anos e cada vez menos atrai a comunidade árabe em suas cidades. Em conversa informal com um membro importante da Federação das Entidades Árabes Brasileiras (Fearab Brasil), o mesmo informou que esse conflito criou uma espécie de "mal-estar" entre os imigrantes e descendentes. 
A primeira delas - Figura 34 - mostra como as adaptações aos pratos tradicionalmente árabes, feitos na cozinha brasileira, não passam despercebidos pela comunidade. Observa-se que essa "desvirtualização" das receitas não é tratada de forma ríspida. Pelo contrário: nota-se que os árabes e descendentes encaram com bom humor situações como, por exemplo, o estranhamento em ver um quibe recheado com ovo ou uma esfirra de linguiça. Tais mudanças nos pratos tradicionalmente árabes não parecem despertar qualquer tipo de polêmica ou preocupação com a questão da preservação da sua identidade. Observa-se também a declaração de pessoas que não têm ascendência árabe, mas que incorporaram as receitas em seu cotidiano, reforçando o que já foi mencionado anteriormente sobre a questão da popularização de alguns pratos de origem árabe.
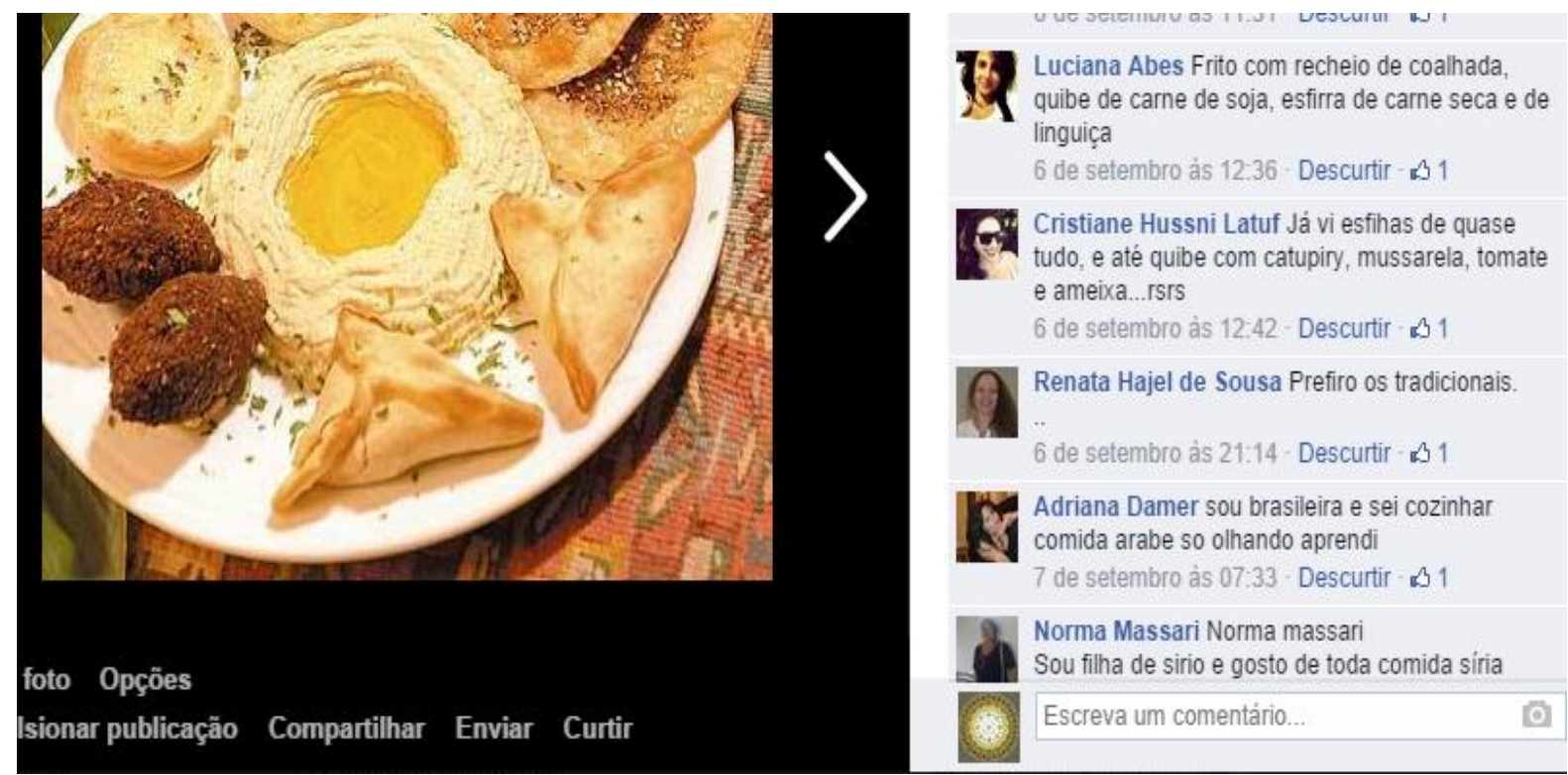

Figura 34 - Trecho de uma publicação sobre as variações de receitas de esfirras e quibes já encontradas pelos leitores da página Presença Árabe no Brasil

A Figura 35 mostra, por sua vez, um tipo de preocupação que nas entrevistas, por exemplo, não chegou a ser notada. A questão da origem das receitas, que muitas vezes, por serem incertas, acabam despertando protestos e contestações por parte de árabes e descendentes. Destaque, neste caso, para a seguinte frase: 
Já não chega todo o processo de "desarabização" de tudo o que fizemos nas ciências, matemática, medicina e outros setores agora até nossos doces querem dizer que não são árabes. (comentário deixado na página Presença Árabe no Brasil em outubro de 2013 em publicação sobre doces árabes).
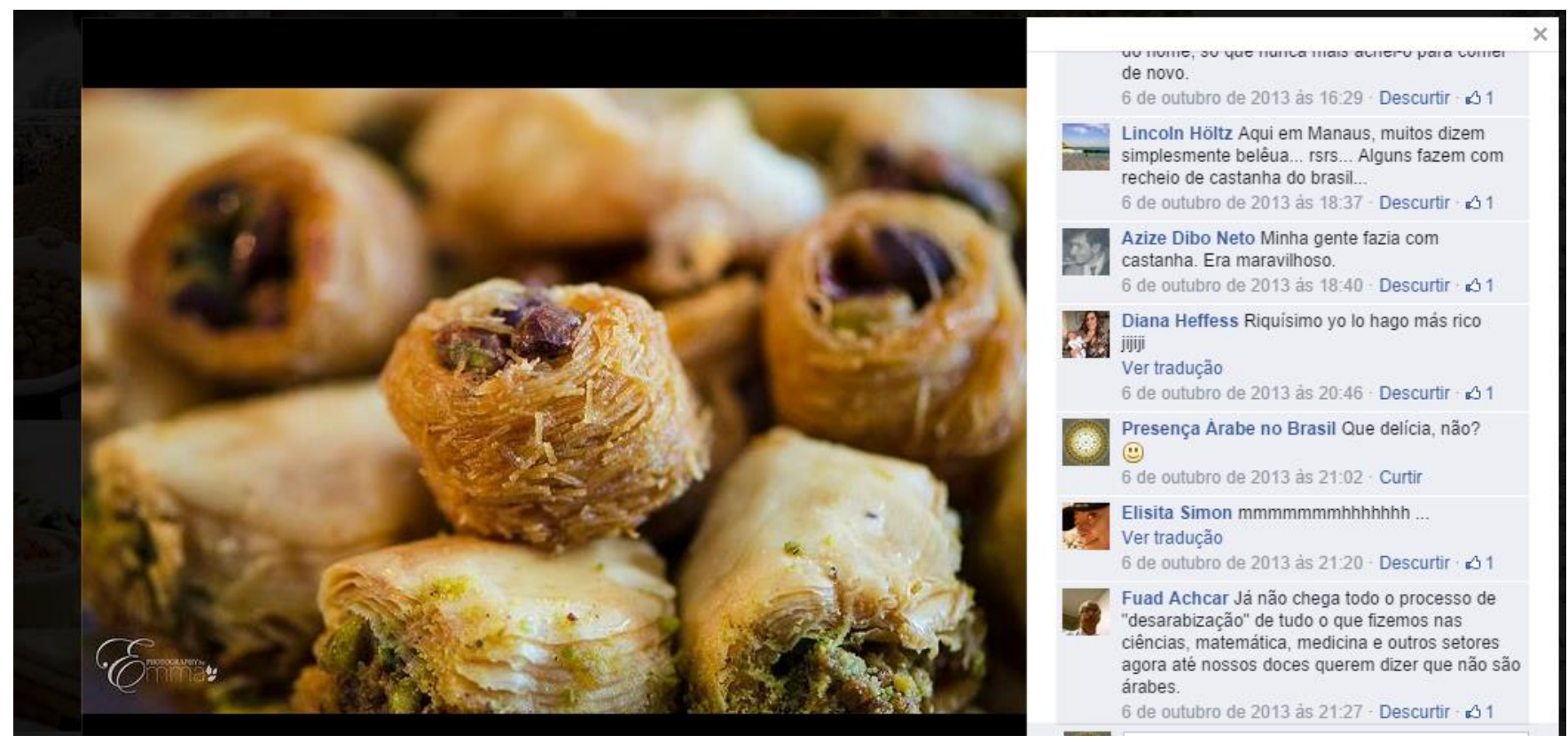

Figura 35 - Comentários dos leitores sobre uma publicação a respeito de doces árabes, na página Presença Árabe no Brasil.

Por fim, um aspecto que já havia sido observado na primeira etapa da pesquisa e, posteriormente, durante as entrevistas, também se fez presente durante a observação participante: a questão da memória afetiva e a constatação de que falar sobre os pratos árabes faz com que as pessoas se sintam efetivamente parte de uma comunidade, e se identifiquem como árabes - ainda que este sentimento não os defina cotidianamente como tais, nem tampouco os faça pertencer a grupos sociais específicos. A fluidez com que este sentimento de pertencimento é evocado sugere que sentir-se árabe não é uma preocupação constante experimentada por imigrantes e descendentes que vivem no Brasil, mas que, por 
meio da alimentação, a identidade árabe é facilmente aflorada. As próximas imagens são exemplos, dentre tantos, de compartilhamentos e comentários em publicações relacionadas aos hábitos e tradições culinárias árabes.

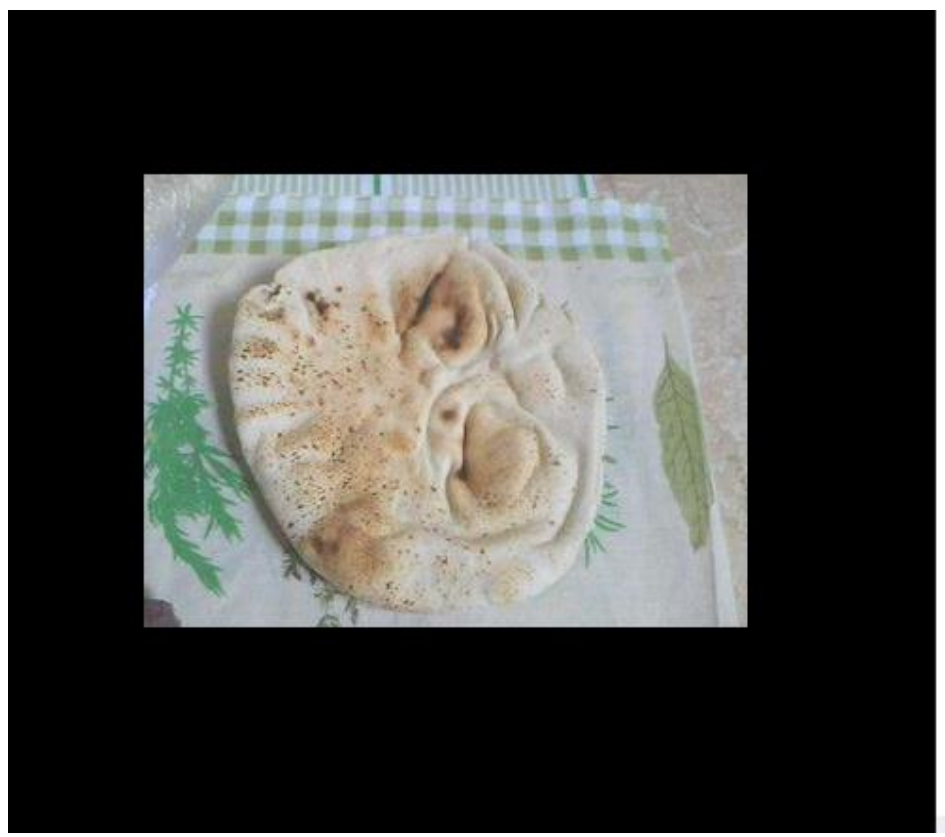

\begin{tabular}{|c|c|c|}
\hline Marcar foto & Adicionar local & Editar \\
\hline \multicolumn{2}{|c|}{ Curtir-Comentar - Compartilhar } & e. \\
\hline \multicolumn{3}{|c|}{$\begin{array}{l}\text { a3 Claudia Helena Guimaraes, Clélia } \\
\text { pessoas curtiram isso. }\end{array}$} \\
\hline \multicolumn{3}{|c|}{ 目 11 compartilhamentos } \\
\hline \multicolumn{3}{|c|}{ Q Ver mais 1 comentário } \\
\hline \multicolumn{3}{|c|}{$\begin{array}{l}\text { Raquel Aparecida Aguiar EU GOSTO } \\
10 \text { de janeiro de } 2012 \text { às } 16: 59 \text { - Descurtir - } 11\end{array}$} \\
\hline \multicolumn{3}{|c|}{$\begin{array}{l}\text { Paula Alves Com queijo branco fica uma } \\
\text { delicial hummmmmm. } \\
10 \text { de janeiro de } 2012 \text { às } 18: 07 \text { - Descurtir - } 31\end{array}$} \\
\hline \multicolumn{3}{|c|}{$\begin{array}{l}\text { Clea David amoadoro!! } \\
11 \text { de janeiro de } 2012 \text { às } 21: 49 \text {. Descurtir - } 32\end{array}$} \\
\hline \multicolumn{3}{|c|}{$\begin{array}{l}\text { Valéria Abdo Esta faltando o tabule. Lembro de } \\
\text { meu avô com um pedaço de pão árabe } \\
\text { "cafunchando" ele no tabule e eu junto. A } \\
\text { saudade dói. } \\
12 \text { de janeiro de } 2012 \text { às } 00: 41 \text { - Descurtir - B } 1\end{array}$} \\
\hline \multicolumn{3}{|c|}{$\begin{array}{l}\text { Hamad Nascime assalam o alaiquam } \\
1 \text { de novembro de } 2012 \text { às } 20: 36 \text { - Curtir }\end{array}$} \\
\hline
\end{tabular}

Figura 36 - Comentários deixados em uma publicação sobre o tradicional "pão sírio" na página Presença Árabe no Brasil, no Facebook.

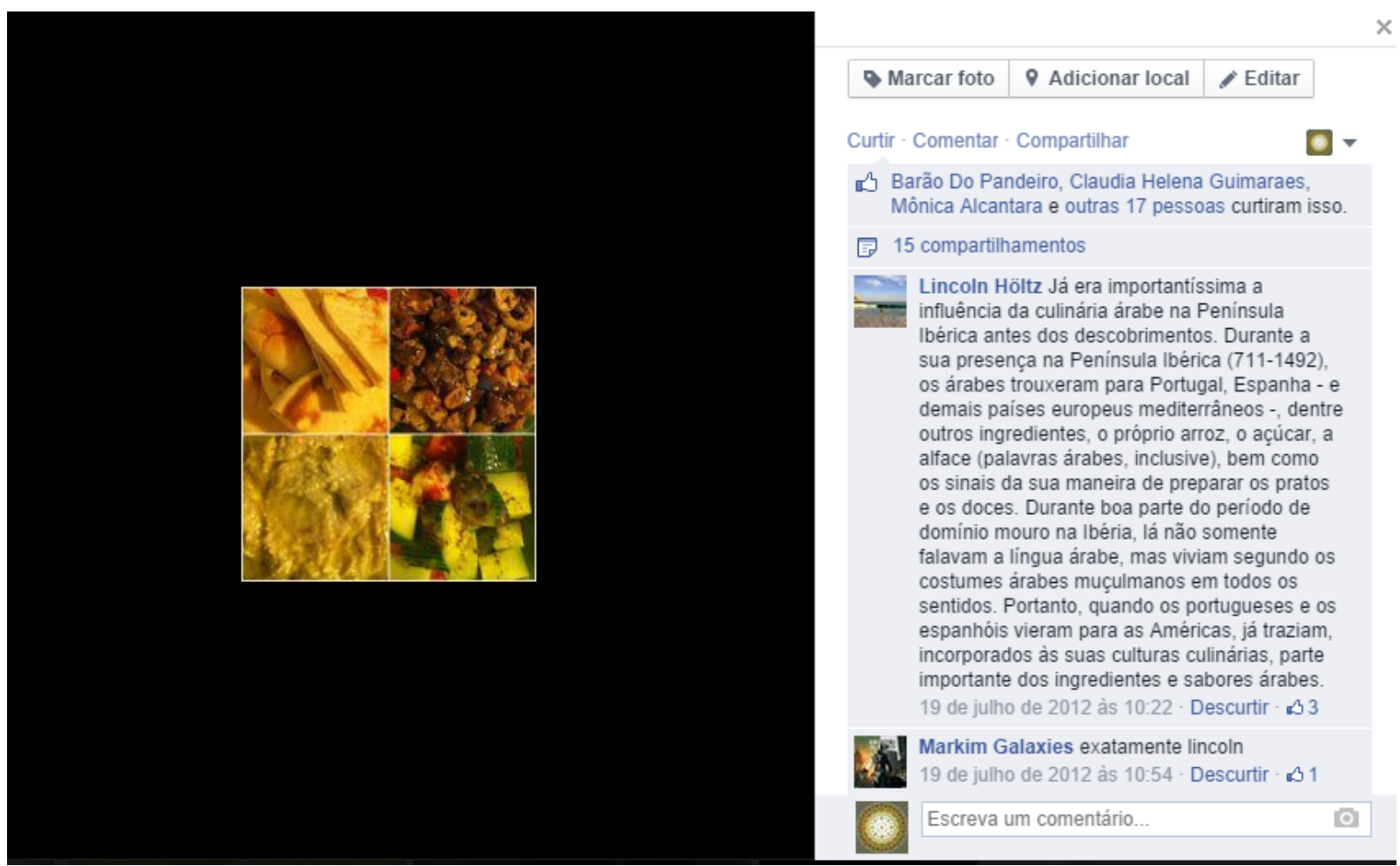


Figura 37 - Comentário deixado em uma publicação sobre hábitos e tradições alimentares árabes na página Presença Árabe no Brasil, no Facebook.

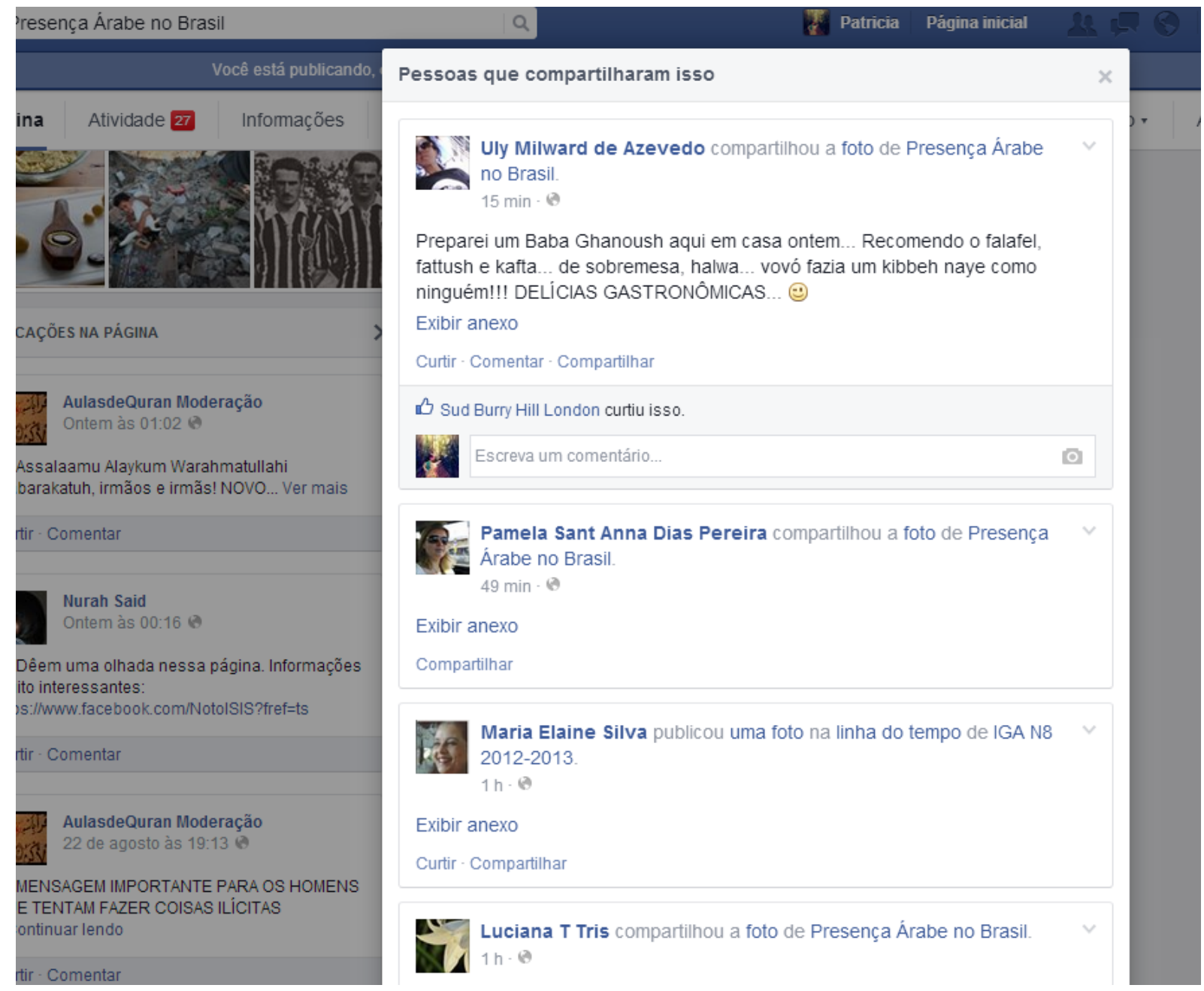

Figura 38 - Comentário feito por um leitor ao compartilhar uma publicação sobre um site de receitas árabes na página Presença Árabe no Brasil, no Facebook.

Esta propriedade com que o assunto da alimentação costumava ser tratado na página Presença Árabe no Brasil em Imagens foi latente desde a sua inauguração, em novembro de 2011. Porém, ela passou a ser analisada com mais dedicação conforme a mesma tendência era observada no decorrer das entrevistas e visitas de campo e a seguir serão apresentadas as principais reflexões às quais se pode chegar ao longo deste período. 


\section{CAPÍtULO 5 \\ ANÁLISE DOS RESULTADOS}

A presença árabe está presente no nosso dia a dia. A começar pelas inúmeras palavras presentes na língua portuguesa, de origem árabe. Se pesquisarmos, veremos que são muito mais do que sabemos e/ou imaginamos. Os pães, de uma maneira geral, por causa do trigo. Os bolos de sabores variados. O jeito brasileiro de fazer o quibe e a esfirra, com outros recheios. Sabe, digo apenas uma tradição culinária, mas a agricultura de nosso país também foi muito influenciada pela cultura árabe. O que se planta no Brasil, tem origem direta com nosso "passado" árabe. Outra coisa... estou meio insegura para dizer isso, mas acho que o café tem origem árabe também. Nesse sentido, o Brasil e todo seu hábito matinal, à tarde, à noite, antes ou depois das refeições, o cafezinho está sempre presente envolto de muito bate-papo e o jeito brasileiro de tomar café. Aliás, é em volta de todas as guloseimas que os encontros, desencontros, começos, términos e infinitas conversas acontecem. [...] Outro ponto de destaque, vejo na decoração. Pode parecer meio viagem da minha parte, ou ignorância, mas essas almofadas que vemos nas vitrines com estampas que lembram o árabe, a mistura das cores harmoniosamente combinadas, os diversos restaurantes que existem na cidade que oferecem o cardápio da comida árabe, as academias de dança do ventre, a nossa refeição do dia a dia em casa mesmo, a simpatia de comer lentilha na virada do ano para trazer prosperidade, as nossas comidas bem temperadas, a arquitetura de algumas casas, o desenho das portas, a mesquita que tem na minha cidade, na roupa de algodão que vestimos. (MTSC, não possui ascendência árabe, residente em Brasília DF)

\subsection{O que pesquisa permitiu constatar}

Esta seção do capítulo tem por objetivo analisar, a partir dos resultados obtidos com a pesquisa, quais as principais percepções dos brasileiros acerca das distintas presenças árabes em nossa cultura e, dedica-se a explorar a vertente da alimentação 
enquanto elemento de reconhecimento identitário, tanto para imigrantes e descendentes quanto para uma parcela da sociedade brasileira que alega perceber alguma influência desta cultura - em que pese a falta de exatidão na definição daquilo que se entende por cultura árabe em nosso cotidiano.

Quando falamos em cultura árabe, devemos levar em consideração o fato de que esta abrange vários países, e que tal generalização, às vezes ignora as diferenças peculiares de cada região. No entanto, as observações destacadas a seguir foram processadas a partir de três técnicas diferentes de coleta de dados, o que permitiu elencar as categorias de análise recorrentes em todas as instâncias de observação ao longo de toda a pesquisa.

O processo de maturação e análise das informações levantadas ao longo de três anos de pesquisa contou, fundamentalmente, com a leitura exaustiva do material coletado depoimentos, mensagens, questionários e anotações feitas em campo. Procurou-se analisar qualitativa, sistemática e rigorosamente todo material reunido até que as "unidades significativas" desse conteúdo acumulado fossem colocadas em evidência. Dentro da abordagem fenomenológica, as unidades não são elementos que existem "per se", mas apenas em relação à perspectiva adotada por quem analisa (BICUDO \& ESPOSITO, 1994). Elas não se encontram diretamente delimitadas de maneira expressa nos depoimentos dos entrevistados, mas se mostram por meio de sua leitura.

Foram destacadas as unidades significativas e agrupadas de acordo com o assunto, a saber: a família e o convívio social, a língua, a religião, o trabalho e a alimentação. Estes foram os temas mais repetidos pelos participantes, ainda que outros assuntos também tenham sido contemplados. No entanto, aqui eles não serão tratados de forma dividida, mas sim contínua, destacando, ao final, a alimentação, que se sobrepôs os demais, além de ter tangenciado, em muitas ocasiões, os demais assuntos identificados como centrais.

\subsubsection{Os principais esterótipos e a reflexão sobre a existência ou não de conflitos}

Não é preconceito. Claro, há um estereótipo de que o árabe acumula dinheiro, é avarento... mas, meu avó é um pouco assim. Ele guarda porque ele passou uma infância difícil. Ele diz que não quer que os netos 
passem o que ele passou no Líbano. A partir de um momento em que eles atingem um status na região eles passam a ser respeitados. E por outro há um pouco de estereótipo do turco que guarda dinheiro. Mas eu acho positivo, não é para excluir. Mostra que a pessoa é notada. (G.P., neto de sírios, residente em Brasília - DF)

Ao longo da pesquisa, foi possível consultar uma vasta bibliografia na qual os árabes foram objeto de estudos e reflexões relacionadas à sua presença no Brasil. Em alguns casos, estudiosos e escritores apontaram para o que eles parecem considerar uma ausência de preconceitos e dificuldades relacionadas a processos de adaptação, ou, quando foram identificados, eles pareciam não ter proporcionado no Brasil o mesmo tipo de situações conflitivas que foram identificadas e inclusive estudadas em outros países. Em outras palavras, ainda que se reconheçam estereótipos, tanto o senso comum quanto boa parte dos estudos realizados sobre o assunto, parecem indicar que o árabe não adquiriu aqui uma conotação de ameaça ou perigo, nos moldes apontados por Edward Said em relação à América do Norte e Europa. No entanto, essa posição não é uníssona e há pesquisadores que mencionam a dificuldade desse processo, ainda que ela não tenha adquirido proporções mais drásticas.

Nunes (2000, p. 155) fala sobre o "sucesso da assimilação" dos migrantes árabes no Brasil e trata o assunto como algo "inquestionável”, muito embora admita que o processo de integração não tenha sido realizado de forma trivial e tenha exigido alguns sacrifícios e adaptações: "para uns foi necessário o abandono da fé ou a mudança nos rituais de suas igrejas; para outros, a perda dos seus sobrenomes, mudanças na organização familiar e nas atividades ocupacionais". A autora também acrescenta uma informação importante. Segundo ela, o Brasil ainda não contou com nenhum tipo de pesquisa específica sobre os estereótipos construídos acerca dos árabes nos meios de comunicação ou nos livros escolares. Mas em seu estudo realizado especificamente em cinco municípios no estado de Goiás com 110 participantes, apenas 21 deles alegaram ter sofrido algum tipo de discriminação, embora os episódios não pudessem ser relacionados, segundo eles, a questões étnicas.

Durante a pesquisa, foi possível captar alguns poucos episódios ligados à discriminação em relação aos árabes no Brasil. Entretanto, cabe ressaltar que as pessoas 
entrevistadas davam muito pouca ênfase ao assunto, que surgia apenas quando os eram questionadas sobre o tema.

Naqueles dias (semana do atentado de 11 de setembro de 2001), aconteceu uma perseguição aos árabes, principalmente em Foz do Iguaçu. Eu, na época, já estava trabalhando no restaurante da família, em São Paulo. Lembro-me de uma equipe de reportagens do SBT. Invadiram o restaurante filmando e o repórter veio para cima de mim perguntando se eu já estava sofrendo retaliações (risos). Eu não apenas desmenti como apontei par alguns fregueses que eram de origem judaica e que sempre almoçavam conosco. (J.G., filho de sírios, residente em São Paulo - SP)

$\mathrm{Na}$ escola onde eu desenvolvo meu projeto de ensino de dança e cultura árabe, noto que os pais das crianças possuem preconceito sim. Alguns alunos não são autorizados a participarem das aulas porque seus pais são evangélicos e não admitem contato com uma cultura, na visão de alguns, de terroristas. Também há aqueles que dizem que a dança é para mulheres e por isso seus filhos não podem estudar. Mas eu noto que pouco a pouco algumas pessoas vão mudando suas percepções. (D.A., não possui ascendência árabe, mas ensina a dança do ventre em uma escola pública de Brasília - DF, onde reside)

Octavio Ianni talvez esteja entre os poucos acadêmicos que identificaram o preconceito contra os árabes no Brasil. Em entrevista publicada na Revista Estudos Avançados (2004), Ianni afirmou existir uma crescente discriminação contra sírios e libaneses, sugerindo ainda a necessidade de se aprofundar o assunto por meio de pesquisas mais sistemáticas.

Sentia muita curiosidade e ao mesmo tempo uma espécie de dívida não paga com a história de homens como meu avô. Ele foi muito discriminado dentro da própria família. Os filhos brasileiros no fundo no fundo sentiam vergonha dele. Envelheceu carcomido de levar a mala nas costas, com as calças por cima da barriga... E completamente obcecado por dinheiro. (J.B., neto de sírios, residente em Porto Alegre - RS) 
Vale lembrar que na década de 1950, o francês Roger Bastide, além de reunir árabes, japoneses e alemães na categoria marginal em sua obra Brasil: terra de contrastes, também concluiu sobre a convergência entre as "civilizações" brasileira e árabe, identificando como semelhanças entre as famílias sírio-libanesas e brasileiras o patriarcalismo, a submissão das mulheres, a mesma obediência respeitosa por parte das crianças, além do mesmo sentimento de solidariedade entre os membros componentes de uma parentela (BASTIDE apud LESSER, 2000).

É inegável que, originalmente, esta presença tenha despertado alguma animosidade por parte das elites brasileiras dado que sua origem não era europeia. Porém, autores como o diretor do Núcleo de Estudos sobre Oriente Médio da Universidade Federal Fluminense, Paulo Hilu (PINTO, 2005), defendem que entre as décadas de 1930 e 1940 esses árabes foram capazes de vencer a discriminação e o racismo. Segundo ele, "tanto o êxito econômico de boa parte dos imigrantes árabes como sua inversão em capital cultural, que levou muitos de seus descendentes a receberem uma educação superior, contribuíram para que protagonizassem um chamativo processo de mobilidade social ascendente". Também sobre esse assunto, o professor Oswaldo Truzzi trata no livro De mascates a doutores: sírios e libaneses em São Paulo.

Ao que tudo indica, em que pese à constatação de que no Brasil os árabes tenham sido vítimas de preconceitos e choques culturais, de modo geral, admite-se e reconhece-se sua presença e sua influência na cultura brasileira. Os levantamentos realizados por meio das entrevistas, da observação participante, das visitas de campo para essa pesquisa, permitiram confirmar - ou, ao menos - se aproximar dessa constatação.

Apesar da ampla difusão de estereótipos negativos em torno da imagem e palavra "turco", termo aplicado indistintamente a todos os imigrantes originários daquela região, o processo de assimilação pelo qual os árabes passaram, ainda que não tenha sido isenta de problemas e dificuldades, permitiu com que esses imigrantes ocupassem um alto grau de acomodação na sociedade brasileira. Para Pinto (idem), o processo de negociação da presença árabe na sociedade brasileira legou aos imigrantes e descendentes no Brasil atual um amplo repertório de identidades como a identidade étnica de "turco" ou árabe até as nacionais (síria, libanesa, palestina) passando por identidades híbridas como a síriolibanesa. 
Roberto Khatlab, pesquisador no Centro de Estudos da Emigração Libanesa da Universidade Notre Dame, no Líbano, ao falar sobre o neologismo Brasilibaneses, escreveu que assim ele identifica os cidadãos binacionais líbano-brasileiros no Líbano conta com cerca de 10 mil pessoas (sem incluir aqueles que retornaram ao Brasil sem ter obtido a nacionalidade). Segundo o autor, eles estão presentes em todo o território libanês, “do Norte (Dar Beechtar...) ao Sul (Kabrikha...), mas principalmente no Bekaa, onde existem aldeias inteiras - como Sultan Yaacoub, Kamed-Lawz e Ghazzé - com 90\% de "brasilibaneses" que falam fluentemente o português e perpetuam os costumes brasileiros (gastronomia, música, arquitetura, agricultura...)".

Uma das principais ruas de Zahlé, a capital do Bekaa, é chamada de "rua Brasil". Existe outra "rua Brasil" em Beirute, perto do porto. Em Byblos fica a pequena capela de Nossa Senhora da Penha do Rio de Janeiro. Em Trípoli, o grande arquiteto brasileiro Oscar Niemeyer desenhou o prédio que abrigou a Feira Internacional. E por todo o Líbano depara-se com nomes em português de lojas, indústrias, produtos e outros, com o Brasil influindo também nos hábitos libaneses, com o café, e sua bandeira nacional passando a fazer parte da paisagem local em época de Copa do Mundo de futebol. (KHATLAB, Roberto, 2011) ${ }^{71}$

Essa proximidade entre os dois países se faz evidente por meio de várias iniciativas. Uma delas, foi a inauguração, em 27 de abril 2011, do Centro Cultural BrasilLíbano (BrasiLiban), que, segundo Roberto Medeiros, ministro-conselheiro e chefe do setor cultural da embaixada brasileira, era uma "antiga reivindicação dos libaneses, de forma geral, e da comunidade de origem brasileira no Líbano, de modo especial. ${ }^{72}$

Ainda que esta pesquisa não tenha se voltado para investigar a fundo a questão da existência ou não de preconceitos e estereótipos para com árabes e seus descendentes,

71 Disponível em: http://conselhobrasileiros.blogspot.com.br/2011/01/quem-sao-os-brasilibaneses.html. Acesso em: jan. 2014

72 Disponível em: http://excessivamentehumano.blogspot.com.br/2011/04/centro-cultural-brasil-libano.html. Acesso em: jan. 2014 
de alguma forma, os dados apresentados ao longo da tese mostraram, ainda que de forma breve, o surgimento de novas impressões acerca dos árabes no Brasil, bem como um recente interesse por parte da sociedade acerca do assunto.

\subsubsection{O sentimento de pertencimento à sociedade brasileira}

Hum... acho que quibe hoje é tão brasileiro pra nós como arroz e feijão. Esfirra também, cada uma com recheio mais brasileiro que o outro. Agora, uma coisa menos "comercial" é a ideia do charuto, feito com folha de repolho. E a prova maior disso é que a minha outra avó (do lado não-árabe) sempre fez charuto de repolho, sem nunca nem pensar em nada de comida árabe. Nem sei se a versão de repolho é árabe, mas pra mim é uma espécie de Malfuf. (P.A., neta de libaneses, residente em Brasília - DF)

De modo geral, ficou latente em toda a pesquisa o sentimento de pertencimento à sociedade brasileira por parte de árabes e descendentes. Não apenas observou-se que o imigrante árabe já se encontra definitivamente instalado no Brasil, como foi possível notar suas contribuições no cotidiano das cidades para onde ele se dirigiu. Este processo se fez visível desde a etapa exploratória deste estudo. Por exemplo, por meio das fotografias das ruas que levam nomes de figuras árabes ilustres, nos restaurantes e estabelecimentos comerciais que vendem produtos e artigos árabes - sejam alimentícios, de dança, música ou decoração - nas associações beneficentes de origem árabe, nas igrejas, mesquitas, cursos de árabe e de dança do ventre - apenas para citar alguns exemplos.

Também na etapa das entrevistas, esse sentimento de pertencimento não passou despercebido. A grande maioria dos participantes alegou sentir-se brasileira, ainda que reconhecesse o peso de suas origens árabes. A preservação da identidade árabe, que outrora foi uma preocupação por parte dos imigrantes sírios e libaneses, em sua maioria, agora se dá de forma espontânea e desprovida de grandes pretensões. Cada vez menos a 
"colônia árabe" se faz presente, se compararmos à dinâmica vivida nos clubes e associações até a década e 1970, aproximadamente.

Por outro lado, a presença árabe no Brasil segue forte e cada vez mais plural, pois as distintas levas migratórias, cada qual com suas particularidades, somadas ao reconhecimento de elementos ibéricos no caldeamento de nossa matriz cultural, fizeram com que a sociedade incorporasse hábitos e tradições identificadas como árabes.

Em Um outro arabesco, Karam (2009) lembra que o árabe passou a ganhar maior reconhecimento no Brasil neoliberal, especialmente no final do século 20. Comida, música e dança - práticas e formas culturais que, segundo ele, foram marginalizadas durante décadas, ganharam espaço no mercado brasileiro a partir dos anos 1970 com a diversificação e a complexificação do mercado de bens simbólicos. A cultura árabe virou, segundo o autor norte-americano, um bem de consumo atraente para o público brasileiro. O autor chama a atenção para o que ele define como "marketing da cultura étnica" e cita a importância das associações religiosas, beneficentes e sociais como círculos de lazer híbridos onde "pessoas da alta sociedade de origem sírio-libanesa dão ênfase aos estilos culturalistas de culinária, dança e música que foram popularizados no mercado brasileiro, cada vez mais diversificado" (KARAM, 2009, p. 197).

Os nacionalismos sírio, libanês ou árabe - além das tradições cristãs orientais e islâmicas - inspiraram dezenas de associações religiosas, beneficentes e sociais em São Paulo, no começo do século XX. Hoje renomadas na colônia e na esfera pública, essas instituições se tornaram espaços luxuosos para o consumo de hummus e caviar, danças do ventre e danças de salão, além de apresentações de oud (alaúde) e caraoquê.

A etinicidade sírio-brasileira, ainda segundo Karam, passou por transformações em termos de consumo, por meio do paradigma assimilacionista visto a partir da Segunda Guerra, e de um modelo de setor de serviços diversificado no final do século XX. Segundo ele, "as formas culturais médio-orientais foram marginalizadas no primeiro paradigma", porém, vem ganhando popularidade nos dias atuais. Se antes eram tomadas como exóticas, ou se não faziam o gosto do brasileiro, agora, comida, dança e música com ênfase no apelo árabe se tornaram objetos de marketing "entre os gostos mais cultivados e os mais populares". 
Já o historiador Oswaldo Truzzi (1997), outra grande referência em estudos sobre o tema e que foi mencionado nesse mesmo capítulo, também costuma tratar a presença árabe no Brasil a partir da ideia de um bem sucedido processo de adaptação. $\mathrm{O}$ parágrafo a seguir, extraído de uma das entrevistas feitas ao longo da pesquisa, pode ser tomado como um exemplo que confirma a teoria de Truzzi.

Ela faz parte da minha vida! Tenho um orgulho tremendo desde o meu sobrenome e tudo o mais. E passo isso para a minha filha também. Só fico frustrada porque não encontro as músicas que meu pai ouvia... Tento me lembrar de tudo o que meu pai dizia e de como ele era com os meus avós! Não sei cozinhar nada típico, mas de vez em quando saio como uma árabe de sangue puro escolhendo algum lugar onde eu me sinta árabe de verdade. [...] Vieram da Síria tentar uma vida melhor... Sei que chegaram de navio com uma só mala na mão. Venderam por um bom tempo meias. E com isso criaram os oito filhos que tiveram. (M.A., neta de libaneses, residente no Rio de Janeiro - RJ)

Também Gilberto Freyre e Câmara Cascudo destacaram que, ao se fixarem em um país fortemente influenciado pela cultura ibérica - e, consequentemente, moura, haja vista que muçulmanos da Península Arábica e do Norte da África estiveram na região hoje conhecida como Portugal e Espanha por aproximadamente oito séculos, tais imigrantes não somente reconheceram traços de sua própria cultura em nossa sociedade, como também não foram tratados como completos estranhos. Em outras palavras, a presença árabe no Brasil antecedeu a chegada dos próprios imigrantes e, possivelmente, contribuiu para evitar um choque cultural quando da sua chegada.

Vejo que na nossa língua, a presença é muito maior do que imaginamos. As palavras em "al-", e outras, que passam despercebidas... comprei um livro que se chama "Mil Palavras Árabes na Língua Portuguesa", é impressionante!! Tenho um caso: o Machado de Assis, em vários livros, usa o termo "salamaleque", tipo "Então, o Fulano estava cheio de salamaleques para receber o Ciclano"... Um dia uma pessoa me perguntou: e aquela palavra do Machado... salamaleques. Respondi, 
prontamente: "ah, é do árabe, el salam a' laicom". E ela ficou sem entender como eu tinha certeza da informação. Com a minha formação, meu olhar para a língua é bastante aguçado também. (E.S, neta de sírios, residente em Belo Horizonte - MG)

Lorenzo Agar Corbinos (2009), em texto sobre a imigração árabe no Chile, aponta para o que ele chama de reetnização, que se esboça em segmentos das novas gerações em um processo comum a diversos grupos humanos e que tem ocorrido em diversas partes do mundo. Os jovens de origem árabe hoje em dia sentem uma "sensibilidade étnica" ou seja, possuem um apego a suas raízes árabes produto da transmissão cultural dos grupos primários e de alguns secundários, como o colégio ou instituições de coletividade, unido a um reconhecimento genotípico evidente. Existe ainda na terceira geração de descendentes uma forma de buscar no mundo globalizado um conjunto de particularidades que marquem diferenças, que manifestem uma diversidade diante de tantas unicidades e uniformidades.

O autor informa que a segunda geração de descendentes está bem adaptada à cultura chilena e que é possível falar em um processo bem sucedido de integração. Segundo ele, a fim de conseguir melhor aceitação por parte da sociedade receptora, é comum que tenham deixado de lado alguns traços da cultura de origem. Porém, já a partir da terceira geração nota-se um esforço por resgatar alguns elementos de identidade árabe, e por isso ele utiliza o termo "re-etnização" para se referir a este processo.

Existem, segundo Corbinos, distintas formas de enfrentar ou reagir a um encontro intercultural. A primeira é acoplar-se de tal forma à sociedade receptora que o resultado final é praticamente a negação das origens por parte do imigrante. Essa atitude acelera sobremaneira o processo de perda de identidade e dificulta a possibilidade de se construir redes de apoio com seus próprios conterrâneos. Com tudo, o acesso social dentro da sociedade de chegada é incerto. Esta situação é bastante comum entre os imigrantes e descendentes da primeira geração.

Outra estratégia é se apegar à cultura de origem de tal forma que se torna difícil o processo de integração à sociedade receptora, dificultando, dessa forma, o diálogo intercultural. Corbinos $(2009$, p. 58) acrescenta que existe uma terceira via, que seria a do imigrante viver entre os dois mundos, com um "pé" em cada lado da ponte. Para o autor, 
trata-se de um processo de paralisia, ou seja, o indivíduo fica envolto numa ambiguidade cultural e não se sente parte de nenhum dos dois mundos. Por fim, o autor acrescenta uma quarta variante de reconhecimento da nova cultura, junto com a preservação de traços culturais ancestrais, sentindo-se plenamente integrado à sociedade receptora, porém, com uma "sensibilidade étnica, ética e estética própria da cultura árabe".

Os árabes cristãos e os árabes muçulmanos partilham uma herança cultural comum, mas estão longe de constituir um todo unificado. Crenças religiosas e sectárias, bem como concepções políticas profundamente enraizadas, os dividem desde sua terra natal. Entretanto, um sentimento de identidade árabe foi pouco a pouco despertado nos países de origem árabe e se espraiou entre os imigrantes residentes no Brasil (NUNES, 2000, p.18)

A partir do momento em que os imigrantes atravessam fronteiras geográficas para dar início a uma nova vida em um outro lugar, levam consigo costumes e vivências que imprimem um selo à sua identidade, sempre dinâmica (idem, p. 59).

Vale dizer que minha avó faleceu há mais de 30 anos, portanto não a conheci. Ela não falava árabe com minha mãe e tias, portanto elas não aprenderam e não falaram comigo e com meu irmão. Elas sabem umas palavras, poucas frases prontas. Meus tios avós irmãos do meu avô também sabem pouca coisa, e os primos da minha mãe (filhos desses tios avós) sabem pouco, como a minha mãe, porque eles não falavam em casa. (E.S, neta de sírios, residente em Belo Horizonte - MG)

As formas de socialização e identificação mais fundamentais são herdadas e aprendidas no âmbito da comunidade cultural de origem. O diálogo intercultural nasce do (re)conhecimento das formas próprias, as formas de outra cultura e, além disso, é capaz de construir um novo diálogo e, assim, criam-se novos valores, resultado do encontro cultural, os quais não respondem nem a uma e nem à outra cultura. Este é o princípio talvez de maior relevância em um diálogo intercultural e na formação de sociedades baseadas no respeito da diversidade comunitária. 


\subsubsection{Presenças árabes, alimentação, memória e identidade}

O comer e beber juntos - que para o árabe permite transformar um inimigo mortal desconhecido em um amigo - libera uma enorme força socializadora. (Simmel, 1910)

A alimentação é um forte registro da cultura de um povo. Ela indica costumes e é uma forma dos imigrantes não perderem boa parte de sua identidade, uma vez que por meio da culinária, estão sempre reforçando hábitos e costumes.

Em todas as etapas da pesquisa aqui apresentada, a manutenção de hábitos e tradições alimentares se mostrou, provavelmente, a estratégia mais valorizada pela comunidade árabe para preservação daqueles elementos que os mantém ligados às suas origens. Mesmo já passados cerca de 130 anos desde o início da vinda de sírios e libaneses para o Brasil, segue frequente encontrar famílias descendentes de imigrantes que têm na alimentação uma das suas marcas identitárias mais fortes.

Em texto escrito para o portal Tenda Árabe, por Virgínia Brandão, põe-se em relevo o fato de que na cultura árabe, "a comida representa uma importante base para a comunicação, e as refeições são o centro dos encontros familiares e círculos sociais". ${ }^{73}$

Segundo ela,

Quer criar um problema em São Paulo? Tente engatar uma discussão numa roda gourmet sobre onde está a melhor comida árabe da cidade. Pronto, a celeuma está armada. Antes que o primeiro diga: 'A boa mesmo era a da minha avó', uns sem-número de palpites saltarão. Nem adianta pedir generalidade. O menu é desfiado, e no final você pode acabar com uma lista do tipo: 'A melhor esfirra fechada de carne em Osasco e o melhor quibe frito no Paraíso'. O fato é que apontar o melhor na cidade que mais recebeu árabes nos dois grandes momentos imigratórios, em

\footnotetext{
${ }^{73}$ Disponível em: http://paposheik.blogspot.com.br/2012/07/a-mesa-com-os-arabes.html. Acesso em: jan.
} 2014. 
1920 e 1940, é uma missão inglória. No máximo, sai uma listinha de lugares incríveis e isso já está de bom tamanho. A comida árabe está naturalmente na vida do paulistano e os restaurantes com essa especialidade fazem parte da paisagem. Cada bairro tem pelo menos um, e sempre haverá o que defenda: "A boa mesmo é a de lá de casa". ${ }^{74}$

O árabe é famoso por sua fartura à mesa. Pela sua hospitalidade, pela preocupação constante em agradar um convidado. E no Brasil, esses hábitos foram passados através das gerações de árabes, além de terem sido incorporados aos hábitos brasileiros.

Ir até a casa da minha tia avó é vê-la arrancar de dentro do primeiro armário um mundo de comida. O falafel dela é inacreditável, a coalhada seca então... essa questão da hospitalidade ligada a comida é muito presente nesse lado da família. Essa minha tia avó também tem um costume engraçado, que é sempre dar um presente pra qualquer pessoa que entra na casa dela. QUALQUER mesmo. Muitas vezes uma lembrancinha, um espelhinho de bolsa, algo assim. (P.A., neta de libaneses, residente em Brasília - DF)

Os quibes e as esfirras, tão popularizados no país, hoje fazem parte do cotidiano de qualquer cidade, sendo muito recorrente encontrarmos tais alimentos em lanchonetes brasileiras. Por meio do conceito de assimilação, seria possível explicarmos esse fenômeno, que permitiu que a cozinha árabe contribuísse de forma excepcional com a cozinha brasileira e vice-versa. O processo de assimilação é dado quando os indivíduos e grupos diferentes aceitam e adquirem padrões comportamentais, tradição, sentimentos e atitudes da outra parte (LAKATOS, 1991, p. 306).

74 BARBOSA, Marta. Site Prazeres da Mesa. Disponível em: http://prazeresdamesa.uol.com.br/exibirMateria/4169/dominio-arabe. Acesso em: jan. 2014. 
Por exemplo, o quibe e a esfirra são comidas encontradas em qualquer bar ou boteco de qualquer cidade do país. (F.L., neto de sírios, residente em São Paulo - SP)

Tem uma história muito legal que já ouvi sobre o quibe se tornar tão conhecido, não sei se você conhece. Quando as famílias chegaram, uma forma de manter o primeiro contato com os vizinhos era mandando quibe pelos filhos que brincavam com os filhos da vizinhança, daí a popularização do quibe. [...] Preservaram: as comidas, que sempre estiveram presentes em todas as casas da família. Todas as tias avós cozinham e a culinária árabe faz parte da vida cotidiana. Minhas tias também cozinham e minha mãe, atualmente, faz comida árabe para vender para fora. A língua foi relativamente preservada, mas em escala muito menor: minha bisavó falava, mas só com as outras senhoras mais idosas da colônia síria daqui. E com uma tia avó (irmã do meu avô, mas que sempre frequentava a casa da minha bisavó). (E.S., neta de sírios, residente em Belo Horizonte - MG)

Sabemos também que muitos pratos árabes foram adaptados para nossa realidade, uma vez que não era possível preservar a fidelidade das receitas que muitas vezes continham ingredientes encontrados com facilidade naquela região, mas aqui eram quase raros.

Eu acho que o tabule passou a ser uma salada normal nos restaurantes self service. Acho isso engraçado. Quibe e esfirra também estão em todas as lanchonetes, o Habib's faz o maior sucesso. Às vezes vejo charuto de repolho em self service também. (E.S., neta de sírios, residente em Belo Horizonte - MG)

Em entrevista ao jornalista Gustavo Chacra, do jornal $O$ Estadão, o ministro do Turismo do Líbano, Fady Abboud, em 2012, esclareceu que "No Brasil, a culinária libanesa ainda é muito concentrada no quibe e na esfirra, que já se transformaram em 
comidas brasileiras. [...] Esfirra é do vale do Beqa (região libanesa de onde vieram muitos imigrantes para o Brasil), ${ }^{, 75}$.

Para que serve a comida? Ela não é apenas uma coleção de produtos que podem ser usados para estudos nutricionais e estatísticos. Ela é também, e ao mesmo tempo, um sistema de comunicação, um corpo de imagens, um protocolo de usos, situações e comportamentos. (BARTHES, 1961, p. 924-933)

Sobre a questão do reconhecimento da origem de uma família por meio da alimentação, em uma das entrevistas realizadas durante a pesquisa, esse tema foi amplamente detalhado. O trecho a seguir foi selecionado para indicar como a forma de preparar um prato também pode estar associada à região de onde as famílias saíram ao virem para o Brasil.

No quibe sírio nós moemos a cebola junto com a hortelã e o quibe fica mais cinza. No Líbano, eles gostam do quibe mais vermelho. Não colocam a hortelã moída e usam pouca cebola, para não oxidar. No tabule sírio, por exemplo, colocamos pepino. Já no libanês não se se coloca pepino de maneira alguma (risos). E se coloca muita, mas muita, salsa. (P.M. neta de sírios, residente em Goiânia - GO)

Entretanto, há outros alimentos que passaram a se tornar bastante populares aqui no Brasil e que têm sido objeto de disputas acirradas para reconhecimento de sua origem. Por exemplo, vale a pena destacar os esforços libaneses para provar que o Falafel é um prato originário no Líbano.

É uma batalha que estamos enfrentando e eu sou um dos líderes. Está claro que hommus, falafel e tabule não são comidas israelenses. Foram

75 Acesso em: jan. 2014. Entrevista completa: http://blogs.estadao.com.br/paladar/homus-e-falafel-foraminventados-no-libano. 
inventados no Líbano e temos provas. São comidas dessa região do mundo árabe, onde conviveram por séculos cristãos, muçulmanos e judeus (Fady Abboud, ministro do turismo do Líbano, em entrevista concedida ao jornal O Estadão em 2012). ${ }^{76}$

A fala do ministro do turismo libanês revela ainda que, por meio da comida, não apenas a identidade de um povo é objeto de preocupação, mas também há uma espécie de disputa política, haja vista que Israel é um país com um longo histórico de conflitos com outros países da região. Na página Presença Árabe no Brasil, ao se publicar a notícia sobre a entrevista com o ministro e os esforços para reconhecimento do falafel como alimento de origem libanesa, reações calorosas foram observadas. Alguns dos comentários deixados na página, mais especificamente nessa publicação, podem ser conferidos a seguir:

É óbvio que Israel está fora desse prato. Como é que. Quando que os judeus da Europa central fizeram falafel? Nunca. Depois que roubaram a Palestina, é que conheceram o falafel de lá. E roubaram a receita, e roubaram o nome, e roubaram o cardápio, como tudo mais que roubaram dos palestinos. Muito me admira uma página voltada para a cultura árabe permitir-se incluir Israel nessa polêmica. Aliás, é sabido que a chamada cozinha de Israel é apenas uma colcha de retalhos de todas as culinárias de outros povos entre os quais os judeus viveram. Nada de original como a requintada culinária árabe. $\mathrm{O}$ falafel é nosso. $\mathrm{O}$ quibe também. (comentário deixado na página Presença Árabe no Brasil em fevereiro de 2013 em publicação sobre o falafel).

${ }^{76}$ Ibidem. 


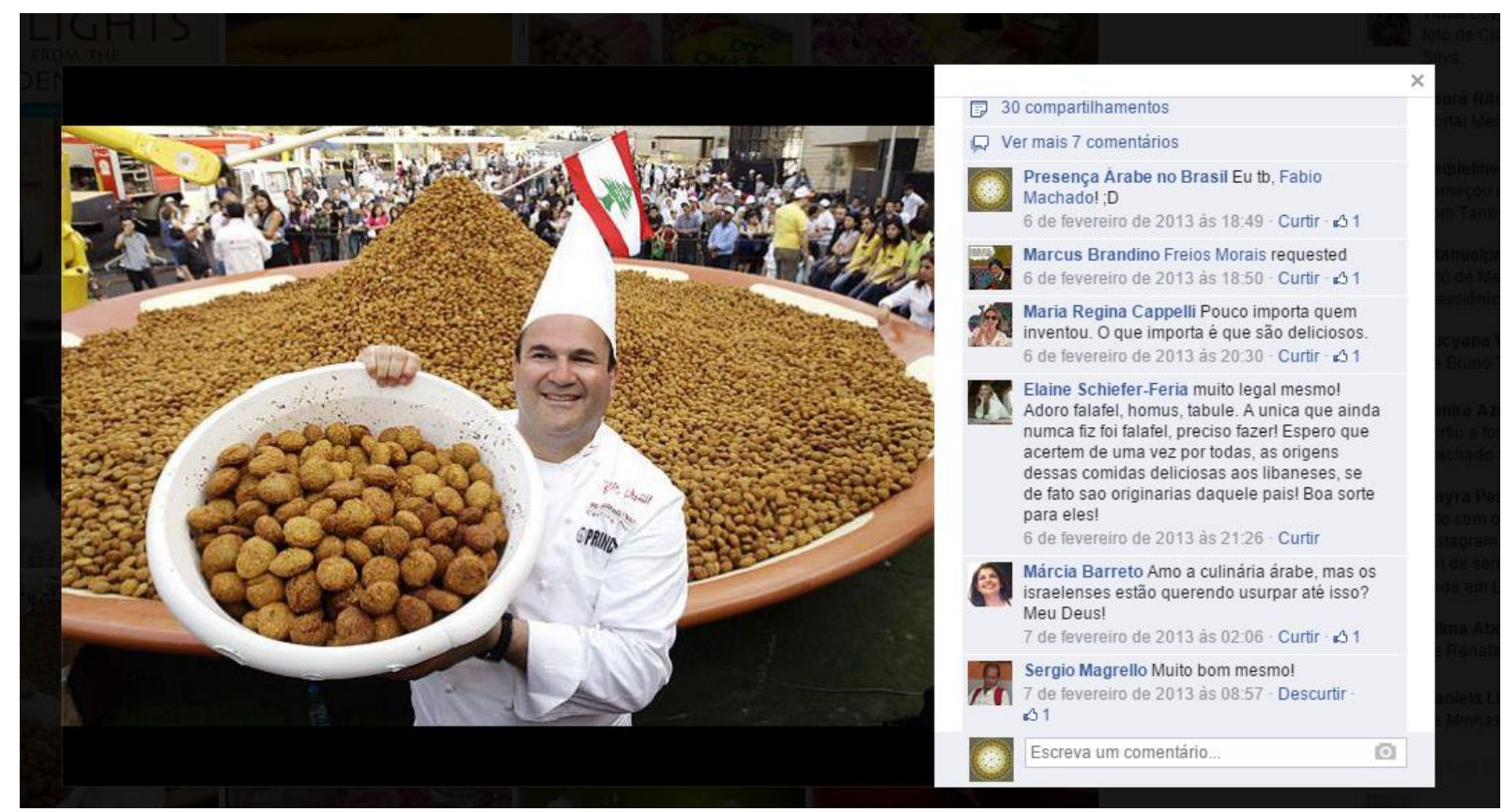

Figura 39 - Comentários sobre a notícia de que o governo do Líbano tenta provar que o falafel é um prato daquele país.

Em outras publicações deixadas na página Presença Árabe no Brasil, bem como nas entrevistas realizadas pela autora, ficou claro a existência de uma preocupação em se reconhecer e se difundir a comida árabe como parte importante da história dessa presença no Brasil, não importando quando essa influência tenha sido iniciada.

Acho que não existe nenhuma cidade no Brasil que não conheça quibe e esfirra. (H.R., neta de libaneses, residente em São Paulo)

Já era importantíssima a influência da culinária árabe na Península Ibérica antes dos descobrimentos. Durante a sua presença na Península Ibérica (711-1492), os árabes trouxeram para Portugal, Espanha - e demais países europeus mediterrâneos -, dentre outros ingredientes, o próprio arroz, o açúcar, a alface (palavras árabes, inclusive), bem como os sinais da sua maneira de preparar os pratos e os doces. Durante boa parte do período de domínio mouro na Ibéria, lá não somente falavam a língua árabe, mas viviam segundo os costumes árabes muçulmanos em todos os sentidos. Portanto, quando os portugueses e os espanhóis vieram para as Américas, já traziam, incorporados às suas culturas culinárias, 
parte importante dos ingredientes e sabores árabes. (comentário deixado na página Presença Árabe no Brasil em julho de 2012)

Ao longo dos três anos que marcam o recorte temporal da coleta de dados desta pesquisa, observou-se que as pessoas, ao falarem sobre as presenças árabes no Brasil, manifestavam-se com grande espontaneidade por meio do tema da alimentação. Ao falarem sobre hábitos e tradições alimentares de origem árabe, frequentemente temas correlatos eram tratados: família e convívio social, quase sempre indicando uma espécie de saudosismo, pois os pratos árabes remetiam às suas origens, à sua infância e a entes queridos já falecidos.

A pesquisa permitiu constatar que, por meio da alimentação os participantes reconheciam suas origens árabes e se identificavam como tais, demonstrando possuir orgulho de um antepassado nem sempre comum a todos, mas que faz parte do imaginário do brasileiro. Notou-se que essa disposição para falar sobre a alimentação frequentemente sobressaiu-se em relação a outros assuntos, os quais costumavam ser tratados com maior cuidado, parecendo não estimular da mesma forma os participantes, a saber: a religião, política e a existência de conflitos.

Ah! Isso é Musk, quando pequena, mastigava isso como um chiclete. Que volta no tempo! (comentário deixado na página Presença Árabe no Brasil, em janeiro de 2014, em publicação sobre sorvete de olíbano).

Acabei de comer um delicioso hommus com pão novinho... Não há melhor do que o feito pela minha Charufe Nasser... Hommus, babaghanoush, quibe cru, charutinhos, carneiro, roz ma djej... Hmmm...Uma delícia pra gaúcho alemão-batata como eu nenhum botar o mínimo defeito... rsrsrs... Já estive no Líbano com ela e nem lá comi melhor! Adoro a minha "turca" e a comida que faz... (comentário deixado na página Presença Árabe no Brasil em outubro de 2013).

A memória afetiva destacou-se como um dos elementos que mais contribuíram para que, por meio da alimentação, imigrantes e descendentes, encontrassem formas de 
manter viva uma identidade "árabe", ainda que desprovida, para muitos, de uma reflexão sobre o que isso significa e como isso se sedimenta em seus papeis cotidianos.

Será que vale a pena modificar a receita tradicional que tanto amamos que nos lembra os nossos familiares? (comentário deixado na página Presença Árabe no Brasil, em novembro de 2013, sobre uma variação de receita de tabule)

Minha infância foi recheada com esse doce (goma árabe), especialmente aos domingos, após o almoço na casa dos meus avós! (comentário deixado na página Presença Árabe no Brasil, em julho de 2012, em publicação sobre o lokum, mais conhecido como goma árabe). 


\section{CAPÍTULO 6 CONCLUSÃO}

A elaboração de uma tese não é um processo trivial. A seu autor, ou sua autora, é necessário um tempo considerável para que se possa amadurecer ideias que, muito embora permeiem o pensamento desde o início do doutorado, tendem a se encaixar já quando a pesquisa caminha para sua conclusão. E aqui não poderia ter sido diferente. No início do doutorado a pesquisa aqui apresentada possuía contornos bastante distintos daqueles que ela adquiriu posteriormente. No entanto, cada etapa, entre erros e acertos, foi fundamental para que a autora encontrasse seu caminho.

Um dos maiores desafios enfrentados durante esse processo foi o fato de que após 2010 um número considerável de países árabes passou por profundas mudanças e enfrentaram conflitos gravíssimos, os quais inicialmente foram nomeados pela imprensa internacional como "Primavera Árabe". As revoluções e manifestações tiveram início em alguns países do Oriente Médio e Norte da África. Tunísia, Egito e Líbia foram os países que passaram por maiores mudanças, mas também houve protestos na Argélia, Bahrein, Djibuti, Iraque, Jordânia, Omã e Iêmen e, em menor escala, no Kuwait, Líbano, Mauritânia, Marrocos, Arábia Saudita, Sudão e Saara Ocidental. A situação na Síria ainda é imprevisível e o país contabilizava até julho de 2014, a triste cifra de mais de 170 mil mortes ocasionadas pelo conflito desde 2011. ${ }^{77}$

Também sobre a Síria, merece destaque o fato já mencionado que a comunidade árabe no Brasil se viu dividida quanto às opiniões e preocupações relacionadas ao país. Destaca-se ainda o episódio ocorrido em 11 de novembro de 2011, quando a Liga dos Estados Árabes suspendeu a Síria da organização, em razão do descumprimento pelo país de acordo que previa que o regime acabaria com a violência

\footnotetext{
77 Disponível em: http://www1.folha.uol.com.br/mundo/2014/07/1483804-conflito-na-siria-ja-deixou-maisde-170-mil-mortos-diz-ong.shtml. Acesso em: set. 2014.
} 
envolvendo forças de segurança e manifestantes civis que protestavam desde março daquele ano. ${ }^{78}$

Aqui no Brasil levou-se um tempo até que as mudanças na política do Egito, Tunísia, Líbia despertassem a preocupação da comunidade árabe no país. No entanto, os conflitos desencadeados na Síria e, em menor proporção, no Líbano, foram os que mais impactaram a chamada "colônia árabe" no Brasil, além de terem alterado sensivelmente a interação social entre imigrantes e descendentes, que assumiram pela primeira vez segundo foi informado em várias entrevistas - posicionamentos opostos influenciados pela questão religiosa ou étnica.

Não apenas durante a etapa de levantamento de dados primários em campo, mas também por meio da observação direta nas redes sociais, nos estabelecimentos religiosos e em conversas informais, foi possível identificar essa divisão acentuada entre imigrantes e descendentes: de um lado, pessoas defendendo a oposição que tenta há mais de três anos derrubar o atual presidente sírio Bashar al-Assad. E de outro, aqueles que demonstram enorme preocupação com os rumos que o país poderá tomar caso ele seja vencido pela atual oposição.

Neste sentido, tais preocupações de alguma maneira modificaram, não apenas a forma como sírios, libaneses (além de outros imigrantes árabes e descendentes), se reconhecem enquanto protagonistas e agentes com capacidade de influenciar o futuro de seus países de origem, mas também na maneira como eles se veem enquanto parte de uma das maiores comunidades árabes do mundo.

Do ponto de vista da realização da pesquisa, essas transformações, para não dizer novamente conflitos, vivenciadas nesses países e que direta ou indiretamente impactou na dinâmica social da comunidade árabe no Brasil, tiveram um impacto muito grande no processo de coleta de dados em campo. Primeiramente porque, tanto em Brasília quanto em outras cidades, boa parte das entidades culturais e religiosas responsáveis pela difusão de informações e preservação de atividades sociais voltadas para a chamada

\footnotetext{
78 Disponível em: http://ultimosegundo.ig.com.br/revoltamundoarabe/liga-arabe-anuncia-suspensao-da-siriae-pede-sancoes-contra-pais/n1597366210144.html. Acesso em: ago. 2014
} 
"colônia", alteraram suas agendas, cancelaram eventos e optaram por adotarem uma espécie de "compasso de espera" até que os conflitos fossem resolvidos, o que ainda não ocorreu. Consequentemente, árabes e descendentes que ainda possuíam vínculos com essas entidades se viram de alguma maneira dispersos e carentes de atividades de promoção cultural e social. Esse fato foi comentado por alguns dos entrevistados que, embora alegassem que em nada alteravam a forma como se sentiam do ponto de vista identitário, já que a maior parte se considera(va) brasileira, e não árabe.

Mesmo entre aqueles com maior vínculo junto à comunidade árabe e aos seus países de origem, tais mudanças igualmente não afetaram sua compreensão sobre quem são e como se sentem. Mas sim, esvaziaram um pouco o papel das instituições ligadas à preservação da cultura árabe no Brasil, especialmente sírio-libanesa, embora algumas também sigam se esforçando para dar visibilidade à causa palestina, à literatura árabe do Magreb, aos eventos promovidos pelas câmaras de comércio, entre outros temas.

Outros dois desafios ocasionados pelos episódios que tomaram conta do cenário internacional envolvendo os países árabes e, consequentemente, parte da população pesquisada durante os últimos quatro anos foram, de um lado, a dificuldade, não apenas em manter o foco no caminho traçado para esta investigação, mas também o interesse da pesquisa em dilatar sempre um pouco mais o recorte temporário do estudo; e, de outro, o incremento considerável no volume de notícias e informações difundidas sobre temas como costumes árabes, extremismo religioso, conflitos entre países, apenas para citar alguns, que imediatamente passaram a despertar o interesse da sociedade sobre o assunto e, consequentemente, a forma como os árabes são percebidos no Brasil.

Se durante décadas a imagem do árabe no Brasil foi associada àquelas dos personagens de livros e novelas, seja do mascate, do vendedor ou do dono da lojinha, esse imaginário começou a ser alterado após o episódio do atentado ao World Trade Center, em agosto de 2001. No entanto, embora a década seguinte tenha permitido observar um incremento de reações negativas e construção de novos estereótipos que o colocava muitas vezes na posição de fanático, ou pessoa perigosa, o árabe no Brasil provavelmente sentiu, nos últimos quatro anos, não apenas o "peso" do preconceito - o qual se alegava baixo se comparado ao de outros países - mas também a força dos conflitos em seus países motivados por diferenças políticas, étnicas e religiosas. 
E essa "combinação" de fatores foi se tornando cada vez mais perceptível conforme a pesquisa chegava ao fim, pois é um fenômeno recente no país e que ainda demandará atenção e produção de novos estudos para se compreender de que forma isso impactará a identidade árabe reconhecida por imigrantes e descendentes no Brasil.

Este estudo permitiu refletir sobre o fato de que, cada vez mais, as diferenças serão acentuadas e cada vez menos será possível falar sobre "o" árabe no Brasil, como durante décadas ocorreu. Os árabes já compõem a sociedade brasileira, já se estabilizaram econômica e socialmente. Já construíram seus vínculos, desenharam novas trajetórias. E, consequentemente, suplantaram o antigo estereótipo. Agora, possuem outros desafios, sendo que um deles é restabelecer junto à sociedade receptora - no caso, a brasileira, a confiança que talvez tenha sido abalada pelos episódios ocorridos nos últimos vinte anos no cenário internacional.

No entanto, ainda é cedo para se dizer como esses conflitos estão impactando a comunidade árabe no Brasil e, ainda, como a sociedade brasileira seguirá reconhecendo uma influência árabe na construção de sua identidade nacional. O que se observa é que por meio da comida, esse reconhecimento permanece inabalado e, quiçá, cada vez mais forte.

A pesquisa permitiu constatar a importância dada por árabes, descendentes, e pela população brasileira de modo geral, à forte relação entre alimentação, memória e identidade árabe, corroborando a literatura consultada para a elaboração deste trabalho, onde tal relação já havia sido tratada a fundo em outros processos migratórios tais como o alemão, japonês e italiano.

No caso dos árabes, o tema foi objeto de discussão, porém, não em estudos sobre deslocamentos humanos, mas sim entre acadêmicos que se dedicaram a discutir as raízes da cultura brasileira e a construção da nossa identidade nacional, muitos deles chamados folcloristas. Intelectuais citados recorrentemente ao longo da tese, tais como Gilberto Freyre e Câmara Cascudo, deram algum destaque sobre a relação entre hábitos e tradições culinárias brasileiros e a herança ibérica, a qual trouxe muito da cultura árabe para nosso cotidiano. Importante lembrar que quando falamos em "cultura árabe" aqui, estamos falando sobre uma espécie de patrimônio cultural imaterial, preservado por meio de saberes, modos de fazer, formas de expressão, celebrações, as festas e danças populares, lendas, músicas, costumes e outras tradições. 
E, neste caso, o reconhecimento de uma presença árabe no Brasil por meio de uma cultura imemorial, impossível de ser capturada do ponto de vista da sua chegada e dos processos pelos quais ela se fixou no dia a dia do brasileiro, mas perceptível e ainda patente, embora pouco estudada nas Ciências Sociais.

O fenômeno da coexistência de distintas presenças árabes na cultura brasileira também não pareceu ter despertado, todavia, o interesse de acadêmicos no campo da sociologia, especialmente no tocante à alimentação. Esta pesquisa lançou luz a um aspecto o qual, ainda que perceptível aos olhos de todo aquele que buscar identificar traços de culturas estrangeiras em nossa identidade nacional, não gerou inquietudes suficientes para ter consolidado ainda uma tradição investigativa sobre o tema.

No Brasil, por exemplo, ao serem questionadas sobre exemplos de pratos árabes, as pessoas rapidamente se recordam do quibe, da esfirra, do tabule e da pasta de grão de bico, conhecida por hommus - comida já incorporada ao cardápio de boa parte dos restaurantes brasileiros e que foi trazida pelos sírios e libaneses. Pratos diferentes daqueles popularizados na Europa, onde o cuscuz (de sêmola de trigo) e o tajine se tornaram comuns em países como França e Espanha, em razão da maior parte dos imigrantes árabes serem de origem magrebina.

O senso comum a respeito das tradições culinárias árabes aqui no Brasil normalmente remete a um imaginário de fartura à mesa, hospitalidade, preocupação constante em agradar um convidado e, entre outras coisas, o gosto pelos doces, especialmente aqueles preparados com nozes, amêndoas, mel e água de flor de laranjeira.

$\mathrm{Na}$ alimentação, é possível recordar o alfajor (castelhano), um doce tradicional da Espanha, Argentina, Chile, Peru, Uruguai e outros países ibero-americanos, cujo nome vem do árabe al hasu, que significa recheado. Também o "alfenim", doce encontrado no interior do Goiás, ou de alguns estados do Nordeste, definido por Luís da Câmara Cascudo como "uma massa de açúcar, seca, muito alva" em forma de animais, flores, cachimbos, peixes. Essa palavra vem do árabe al-fenid ou al-fanid, e significa branco ou alvo. Segundo Cascudo (Apud VALENTE, 1995, p. 141), o Alfenim foi muito popular em Portugal nos fins do século XV e princípios do século XVI, tendo sido citado em obras de Gil Vicente e de Jorge Ferreira de Vasconcelos. 
Dentro de uma perspectiva sociológica, a identificação dessa pluralidade de presenças árabes em nossa cultura se observa em alguns pontos principais. O primeiro deles reside no fato de que árabes e descendentes alegam um forte sentimento de pertencimento à sociedade brasileira e, mesmo após os laços identitários familiares se mostrarem diminutos, a relação entre memória afetiva e identidade permanece forte quando observada pelo viés da alimentação. Essa fluidez referente ao sentimento de pertencimento a uma cultura estrangeira, a qual afeta muito pouco a forma como árabes e descendentes se reconhecem enquanto brasileiros ou integrados à cultura da sociedade receptora, vai de encontro ao que o sociólogo e teórico da cultura jamaicano Stuart Hall (1997), falecido no início de 2014, defendia sobre a questão das identidades culturais:

Dentro de nós há identidades contraditórias, empurrando em diferentes direções, de tal modo que nossas identificações estão sendo continuamente deslocadas. [...] À medida em que os sistemas de significação e representação cultural se multiplicam, somos confrontados por uma multiplicidade desconcertante e cambiante de identidades possíveis. (HALL, 1997, p. 14)

Complementarmente, embora não tenha se observado entre os participantes da pesquisa um discurso de reforço de "uma" única identidade árabe, há elementos da cozinha brasileira - a qual bebe em várias fontes - que se tornaram notórios e rapidamente identificados e reconhecidos como "árabe", são eles: quibe, esfirra, tabule, pão sírio - para citar os mais recorrentes ao longo do estudo, e que possuem uma relação direta com a imigração sírio-libanesa ao Brasil, além de outros já incorporados às tradições regionais, como o alfenim, o cuscuz e o café, hábitos que foram levados pelos "mouros", para usar as palavras de Câmara Cascudo e Gilberto Freyre, à Península Ibérica e, indiretamente trazidos para o Brasil por meio da figura do colonizador.

Esses elementos identitários ligados à alimentação foram os que mais se mostraram, nas diversas incursões em campo, apreendidos pelos imigrantes, mas, especialmente, por descendentes, inclusive de terceira e quarta geração, como um importante elo que estabelece algum sentimento de pertencimento a "uma" cultura, embora tenha ficado claro que há pouca preocupação em se definir qual. Ou seja, cada pessoa, 
embora admita identificar-se com uma "cultura árabe", vê e sente, e consequentemente, percebe-se árabe, de forma distinta e muito pessoal, a partir das suas próprias experiências vividas ao longo da sua trajetória.

Por outro lado, a sociedade receptora - no caso, a brasileira - lida de forma bastante positiva com esse processo de intercâmbio cultural, seja porque a comida possui uma capacidade clara de transpor barreiras, seja pela existência de resquícios imateriais árabes em nossa identidade cultural, herdada via a figura do colonizador.

À guisa de conclusão, cabe ainda acrescentar que nos três meses finais que antecederam a finalização da tese ora apresentada, a pesquisadora foi convidada a realizar um trabalho de assessoria junto à Presidência da Federação das Entidades Americano-Árabes - Fearab América, atualmente sediada em Brasília. $^{79}$ A experiência revelou ainda algumas informações importantes, algumas até então não percebidas durante a etapa de pesquisa de campo, realizada entre 2011 e primeiro semestre de 2014. E outras as quais reafirmaram grande parte das impressões apreendidas ao longo do estudo e que já foram mencionados anteriormente, no capítulo de apresentação dos resultados da pesquisa.

A observação que merece maior atenção neste caso refere-se ao fato de que foi possível captar uma espécie de nostalgia por parte de integrantes e pessoas ligadas à Federação e a entidades afins quanto aos tempos em que esses grupos se sentiam representantes da comunidade ou, para usar a expressão mais recorrente, da colônia árabe no Brasil. A ideia de colônia ainda parece bastante forte principalmente em estados onde a presença sírio-libanesa foi muito forte durante as primeiras levas migratórias: São Paulo, Rio de Janeiro, Minas Gerais e Goiás. Entretanto, atualmente

${ }^{79} \mathrm{O}$ convite foi feito em razão da minha residência em Brasília, a qual coincidiu com o fato de que o Presidente da Fearab América, ao tomar posse do cargo - cuja gestão é de três anos a contar a partir de março de 2014 - consultou algumas pessoas ligadas à entidade sobre possíveis nomes de pessoas que poderiam assessorá-lo em atividades voltadas à difusão da cultura árabe e que morassem na capital federal, local onde ele também reside. O convite foi aceito, especialmente, porque considerei esta ser uma oportunidade importante de ainda poder me acercar um pouco mais sobre a dinâmica de uma entidade deste porte mesmo estando em Brasília, uma vez que a maioria dos institutos de cultura e pesquisa ligados ao mundo árabe no Brasil se encontram em estados como São Paulo, Rio de Janeiro, Rio Grande do Sul. 
ela é mencionada com grande nostalgia, como se já fosse difícil capturar sua relevância neste momento, ao contrário do que outrora ela chegou a ser. Ademais, a família - e com ela os eventos sociais - foram as maiores referências dos participantes da pesquisa quando falavam sobre o sentimento de pertencimento a uma cultura dita "árabe".

Se levarmos em consideração a dimensão numérica da presença árabe imigrante e descendente no país, o sentimento de pertencimento proporcionado ou motivado por associações e grupos sociais estaria aquém do estimado por algumas entidades que envidam esforços para difusão de uma chamada identidade árabe no Brasil.

Isso se dá provavelmente porque: (i) sua presença atualmente se concentra em grandes capitais e, na prática, sua representatividade varia sobremaneira; (ii) ademais, ao observar a agenda de atividades, eventos sociais e mecanismos de interação junto à comunidade genericamente chamada de árabe, a pesquisa relevou uma dificuldade em se alcançar aquele que seria seu "público-alvo" e; (iii) boa parte desses grupos não apenas se concentram na comunidade sírio-libanesa, como também não alcançam uma parte considerável da população migrante e descendente. Cabe comentar que a maioria dos entrevistados que contribuíram para esta pesquisa pessoas que vivem em cidades como Brasília, Rio de Janeiro, Anápolis, São Paulo, Juiz de Fora e Foz do Iguaçu, embora se sentissem árabes, pouco falavam sobre esse convívio - que há cerca de 30 anos possuía outro papel social - e menos ainda, sobre o papel dessas associações para a manutenção de suas identidades.

Complementarmente, merece menção o fato de que uma parcela dos atores mais ativos e participantes das entidades que ainda trabalham pelo resgate da história da imigração árabe no Brasil, bem como pela convivência entre imigrantes e descendentes, parecem se articular em duas principais frentes. A primeira delas, na verdade, é formada por uma combinação entre política e comércio, e que culmina com uma atuação importante - e cada vez mais emblemática da Câmara de Comércio Árabe 
Brasileira, que há mais de 60 anos, atua no incremento de intercâmbios econômicos, culturais e turísticos entre árabes e brasileiros. ${ }^{80}$

A outra frente, que aqui poderia ser chamada de "acadêmica", ganha cada vez mais fôlego com a formação de grupos de estudos relacionados, não necessariamente à cultura árabe, mas: (i) à difusão do idioma; (ii) à questão das relações internacionais e; (iii) ao tema da religião, mais especificamente ao Islã e seu crescimento também no Brasil. Destaque para o Centro de Estudos Árabes da Universidade de São Paulo (USP) e o Núcleo de Estudos do Oriente Médio da Universidade Federal Fluminense (UFF).

Por fim, e retornando ao tema da alimentação, observou-se a existência, cada vez maior, de pessoas que dotam de um sentimento de pertencimento à cultura árabe, mas que não a definem exatamente como síria, libanesa ou palestina - apenas para citar as principais origens identificadas nesta pesquisa. São pessoas que reconhecem aspectos identificados como "árabes" em sua formação enquanto indivíduos, sem necessariamente se atrelarem a grupos específicos ou a instituições representativas dessas comunidades no Brasil.

Considerando possível fazer uso das palavras de Bauman (2003) e tratar como um reflexo da "modernidade líquida" (na qual nos encontramos imersos) essa fluidez percebida pela dificuldade em se delimitar quem são os árabes e como, no Brasil, se reconhecem como tal, a tese chega ao fim propondo uma reflexão a respeito das identidades partilhadas por imigrantes e descendentes, cada vez mais plurais quando comparadas àquela que em outros tempos esteve presente nas famílias de origem árabe no Brasil. Tal fluidez parece ter alterado profundamente a forma como as pessoas se reconhecem, interagem entre si e, consequentemente, como percebem o outro.

${ }^{80}$ Disponível em: http://www.ccab.org.br/arabe-brasil/br/quem-somos.fss. Acesso em: ago. 2014. 


\section{REFERÊNCIAS}

ABREU, Maria Youssef; AGUILERA, Vanderci de Andrade. A influência da língua árabe no português brasileiro: a contribuição dos escravos africanos e da imigração libanesa. In: Revista Entretextos, v. 10, n. 2, 2010. Pós-Graduação em Estudos da Linguagem. Universidade Estadual de Londrina.

AB'SÁBER, Aziz Nacib. In: Relações entre o Brasil e o mundo árabe: construção e perspectivas. Fundação Alexandre de Gusmão (FUNAG), 2000.

ADAMI, Vítor Hugo S. Etnografias como métodos e dados de pesquisas: as experiências etnográficas que atravessam os movimentos Hare Krishna brasileiro e espanhol. In: Teorías y práticas emergentes en antropología de la religión, 2008.

AKMIR, Abdeluahed (Org.). Los árabes en América Latina: historia de una emigración. Madrid: Siglo XXI de España Editores, 2009.

AL-SHEREIDAH, Mazhar. El mundo árabe y occidente: el petróleo de rodillas. Caracas: Fondo Editorial Tropykos/Comisión de Estudios de Postgrado Facultad de Ciencias Económicas y Sociales. Universidad Central de Venezuela, 1995.

ALVES, José Eustáquio Diniz. Transição demográfica nos países islâmicos. Artigo publicado na página eletrônica do Laboratório de Demografia e Estudos Populacionais da Universidade Federal de Juiz de Fora, 2010.

AMADO, Jorge. A descoberta da América pelos turcos. Rio de Janeiro: Record, 1994.

AMARAL, Adriana et al. Netnografia como aporte metodológico da pesquisa em comunicação digital. In: Sessões do Imaginário: cinema, cibercultura, tecnologias da imagem, ano 13, n. 20, 2008 .

AMON, Denise; MENASCHE, Renata. Comida como narrativa da memória social. In: Sociedade e cultura, v.11, n.1, jan/jun., 2008, p. 13-21.

AKMIR, Abdeluahed. In: Los Árabes en América Latina. Introducción. Coord. Abdeluahed Akmir. Biblioteca Casa Árabe. Ed. Siglo XXI. Madrid, 2009. 
ARAUJO, Marivânia Conceição. A teoria das representações sociais e a pesquisa antropológica. Revista Hospitalidade, ano V, n. 2, São Paulo, jul.- dez., 2008, p. 98-119.

ARBEX JR., José. Reflexões sobre o nacionalismo árabe. Artigo publicado no conteúdo do curso oferecido pelo Instituto de Cultura Árabe ICArabe: Panorama da Cultura Árabe II. São Paulo, $2009 . \quad$ Disponível em: http://www.icarabe.org/sites/default/files/pdfs/panorama_da_cultura_arabe_2_-_aula_1.pdf ASFORA, Eliane. Doutor Gilberto Freyre e o reconhecimento da culinária como fenômeno social. In: Anais gastronomia em Gilberto Freyre. Fundação Gilberto Freyre, 2005.

ASSIS, Glaucia de Oliveira; SASAKI, Elisa Masse. Teorias das migrações internacionais. XII Encontro Nacional da ABEP 2000. GT de Migração. Caxambu, Outubro de 2000.

ASSMANN, Jan. Communicative and Cultural Memory. In: ERLL, A, NÜNNING, A. (Org.). Cultural memory studies: an international and interdisciplinary handbook. Berlin/New York: De Gruyter, 2008.

ASSUNÇÃO, Viviane Kraieski. Anais 26 Reunião Brasileira de Antropologia, 2007. Disponível em:

http://www.abant.org.br/conteudo/ANAIS/CD_Virtual_26_RBA/grupos_de_trabalho/traba lhos/GT\%2027/viviane\%20kraieski\%20de\%20assun\%C3\%A7\%C3\%A3o.pdf

BARROS, Liza Dumovich. YA HABIBI: Crise de vida, afeto e reconfiguração do self religioso na conversão de mulheres ao islã, na Mesquita da Luz. Dissertação apresentada ao Programa de Pós-Graduação em Antropologia da Universidade Federal Fluminense. Niterói, 2012.

BARTHES, Roland. A mensagem fotográfica. In: LIMA, L. Costa (Org.). Teoria da cultura de massa. Rio de Janeiro: Saga, 1969.

BARTHES, Roland. Por una psico-sociología de la alimentación contemporánea. In: EMPIRIA: Revista de metodología de Ciencias Sociales, ${ }^{\circ}$ 11, enero-junio, 2006, p. $205-$ 221. 
BARTHES, Roland. Pour une psycho-sociologie de l'alimentation contemporaine. In: MARTY, Eric (Ed.). Roland Barthes: oeuvres complètes - Tome I: 1942-1965. Paris: Éditions du Seuil, 1993, p. 924-933 (1. ed. original 1961).

BAYOUMI, Moustafa. How Does It Feel to Be a Problem?: being young and arab in america. Penguin Books, 2009.

BELTRÃO, Cláudia. Os árabes na Idade Média: os senhores do deserto. São Paulo: FTD, 2000 .

BERGER, Peter L.; LUCKMANN, Thomas. A construção social da realidade. Petrópolis: Vozes, 1974.

BERGSON, Henri. Matéria e memória. São Paulo: Martins Fontes, 1999.

BICUDO, Maria Aparecida; ESPOSITO, Vitória Helena. Pesquisa qualitativa em educação: um enfoque fenomenológico. Editora UNIMEP, 1994.

BOTELHO, Fernanda de Oliveira. A memória como recurso para as políticas públicas culturais: a experiência da Casinha da Memória de Ourinhos-SP. Trabalho de conclusão do curso de pós- graduação em Gestão de Projetos Culturais e Organização de Eventos. CELACC/ ECA-USP, 2012.

BOSI, Ecléa. Memória e sociedade: lembranças de velhos. São Paulo: Companhia das Letras, 2009.

BURKE, Peter. Variedades de história cultural. Rio de Janeiro: Civilização Brasileira, 2000.

CAMPOS, Mintaha Alcuri. Turco pobre, sírio remediado, libanês rico. Vitória: Instituto Jones dos Santos Neves, 1987.

CANESQUI, Ana Maria; DIEZ GARCIA, Rosa Wanda (Org.). Antropologia e nutrição: um diálogo possível. Rio de Janeiro: FIOCRUZ, 2005.

CARNEIRO, Henrique. Comida e Sociedade: significados sociais na história da alimentação. História: questões \& debates, Curitiba, n. 42, EdUFPR, 2005, p. 71-80. 
CARRÉ, Olivier. La Syrie d'aujourd'hui. Andre Raymond (Org.). In: Capítulo 6 Mvto ideologico baathista. Institut de recherches et d'études sur le monde arabe et musulman, Éditions du CNRS. 1980, Publication sur OpenEdition Books : 22 avril 2013.

CASA ÁRABE. Contribuciones árabes a las identidades iberoamericanas. Espanha, 2009.

CASCUDO, Luís da Câmara. Mouros, Franceses e Judeus: três presenças no Brasil. São Paulo: Global, 2001.

História da alimentação no Brasil. Belo Horizonte: Itatiaia, 1983.

CASTELLS, Manuel. A Galáxia Internet: reflexões sobre internet, negócios e sociedade. Lisboa: Fundação Calouste Gulbenkian, 2004.

CASTLES, Stephen; MILLER, Mark. The age of migration: international population movements in the modern world. Londres: Macmillan Press, 2009.

CAVIGNAC, J. A.; OLIVEIRA, L. A. História e Etnografia Nativas da Alimentação no Brasil: Notas biográficas a Respeito de um Antropólogo Provinciano. Imburana: Revista do Núcleo Câmara Cascudo de Estudos Norte-Rio-Grandenses / UFRN, n. 2, nov., 2010.

CHOHFI, Osmar. Apresentação. In: Relações entre o Brasil e o Mundo Árabe: construção e perspectivas. Brasília: Fundação Alexandre de Gusmão, 2001.

CLEMESHA, Arlene E. História e Representações da História Árabe Contemporânea. In: VARGENS. João B. M.; CAFFARO, Paula da Costa (Org.). Arabismo: um tema e suas representações. Rio Bonito: Almádena, v. 1, 2010, p. 89-98.

A imigração árabe no Brasil. Arab Scientific Publishers, 2010.

CORBINOS, Agar. El aporte de los árabes al desarrollo y la cultura en Chile. In: Contribuciones árabes a las identidades iberoamericanas. Casa Árabe, Espanha, 2009.

CUNHA, Maria Jandyra Cavalcanti et al. Migração e identidade: olhares sobre o tema. São Paulo: Centauro, 2007.

DAMATTA, Roberto. O que faz o brasil, Brasil? Rio de Janeiro: Rocco, 1986. 
DAWISHA, Adeed. Arab nationalism in the twentieth century: from triumph to despair. New Jersey: Princeton University Press, 2003.

DOUN, Taufik. Confissões e indiscrições: meio século de experiências em quatro continentes. São Paulo: Editora Árabe, 1943.

DUTRA, Rogéria Campos de Almeida. Cozinha e Identidade Nacional: notas sobre a culinária na formação da cultura brasileira segundo Gilberto Freyre e Luís da Câmara Cascudo. In: Anais do Seminário Gastronomia em Gilberto Freyre. Recife: Fundação Gilberto Freyre, 2005, p. 31-36.

EL-MOOR, Patrícia Dario. A imigração árabe no Brasil. Monografia realizada como conclusão de Graduação em Sociologia. Universidade de Brasília, 1997.

ERLL, Astrid. Cultural Memory Studies: an introduction. In: ERLL, A; NÜNNING, A. (Org.). Cultural memory studies: an international and interdisciplinary handbook. Berlin/New York: De Gruyter, 2008.

FAUSTO, Boris. Fazer a América: a imigração em massa para a América Latina. São Paulo: EDUSP, 1999.

FAZITO, Dimitri. Reflexões sobre os sistemas de migração internacional: proposta para uma análise estrutural dos mecanismos intermediários. Tese de Doutorado. Universidade Federal de Minas Gerais, 2005.

FERABOLLI, Sílvia. Relações Internacionais do Mundo Árabe (1954-2004): os desafios para a realização da utopia pan-arabista. Revista Contexto Internacional, vol. 29, n. 1, Rio de Janeiro, janeiro/junho, 2007, p. 63-97.

FEREIRA, Francirosy Campos Barbosa. Contando histórias - aprendendo com Sherazade - entre imagens e performances. RBSE - Revista Brasileira de Sociologia da Emoção, n.11 (31), abr., 2012, p. 165-179.

(Org.) Olhares femininos sobre o islã: etnografias, metodologias, imagens. São Paulo: HUCITEC.

FORNAZARI, Sandro Kobol. O bergsonismo de Gilles Deleuze. In: Trans/Form/Ação, vol.27, n.2, 2004. 
FORTES, Pablo Dias. Mouropeus? Breve ensaio indagativo sobre o estatuto da lusodescendência no Brasil e suas implicações éticas. Rio de Janeiro, 2013. Disponível em: http://pablodiasfortes.files.wordpress.com/2013/01/mouropeus.pdf.

FRAZER, Márcia Tourinho Dantas; GONDIM, Sônia Maria Guedes. Da fala do outro ao texto negociado: discussões sobre a entrevista na pesquisa qualitativa. Disponível em: http://www.scielo.br/scielo.php?pid=S0103-863X2004000200004\&script=sci_arttext.

FREYRE, Gilberto. Casa Grande \& Senzala. Recife: Global, 2003.

FUNDAÇÃO ALEXANDRE DE GUSMÃO. Relações entre o Brasil e o Mundo Árabe: construção e perspectivas. Brasília: 2001.

GARCIA, Meirelle. A representação do imigrante árabe em A descoberta da América pelos turcos, de Jorge Amado. Amerika, Le Brésil de Jorge Amado: perspectives interculturelles, $\quad$ n. 10/2014. Disponível em: http://www.aplvlanguesmodernes.org/spip.php?article5560.

GATTAI, Zélia. Anarquistas, Graças a Deus. Rio de Janeiro: Record, 1979.

GATTAZ, André. Do Líbano ao Brasil: história oral de imigrantes. Salvador: Pontocom, 2012.

GIDDENS, Anthony; TURNER, Jonathan. Teoria social hoje. São Paulo: EdUNESP, 1999.

GONÇALVES, José Reginaldo Santos. A fome e o paladar: a antropologia nativa de Luis da Câmara Cascudo. In: Estudos Históricos, n. 33, Rio de Janeiro, 2004.

GUERIOS, Paulo Renato. As condições sociais de produção das lembranças entre imigrantes ucranianos. Mana, v.14, n. 2, Rio de Janeiro, out. 2008. Disponível em: http://www.scielo.br/scielo.php?script=sci_arttext\&pid=S0104-

93132008000200004\&lng=en\&nrm=iso. Acesso em: 6 set. 2014 . http://dx.doi.org/10.1590/S0104-93132008000200004. 
GODOLPHIM, Nuno. A fotografia como recurso narrativo: problemas sobre a apropriação da imagem enquanto mensagem antropológica.

In: Horizontes antropológicos, ano 1, n. 2, Porto Alegre, jul./set., 1995, p. 161-185.

ACCESS. Arab Community Center for Economic and Social Services Guide to Arab Culture. Health Care Delivery to the Arab American Community. 1999.

HAJJAR, Claude Fahd. Imigração árabe: 100 anos de reflexão. São Paulo: Ícone, 1985.

HALL, Stuart. Identidades Culturais na Pós-Modernidade. Rio de Janeiro: DP\&A, 1997.

HALLIDAY, Fred. 100 Mitos sobre o Médio Oriente. Lisboa: Edições tinta-da-china, 2005.

HATOUM, Milton. Arabescos Brasileños. In: Contribuciones árabes a las identidades iberoamericanas. Madrid: Casa Árabe, 2009.

HOURANI, Albert. Uma história dos povos árabes. São Paulo: Companhia das Letras, 1994.

JODELET, D. Représentation sociale: phénomene, concept et théorie. In: MOSCOVICI, Serge (Dir.). Psychologie sociale. Paris: Presses Universitaires de France, 1990.

KARAM, John Tofik. Um outro arabesco: etnicidade sírio-libanesa no Brasil. São Paulo: Martins Fontes, 2009.

KASSIR, Samir. Being Arab. London/New York: Verso, 2013.

KABCHI, Raymundo (Coord.). El Mundo Árabe y América Latina. Madrid: Unesco, 1997.

KHATLAB, Roberto. Marhjar: saga libanesa no Brasil. Mokhtarat, 2002.

KHOURI, Juliana Mouawad. Pelos Caminhos de São Paulo: a Trajetória dos Sírios e Libaneses na cidade. Dissertação de Mestrado apresentada ao Programa de Pós-Graduação em Estudos Judaicos e Árabes do Departamento de Letras Orientais da Faculdade de Filosofia, Letras e Ciências Humanas, da Universidade de São Paulo. São Paulo, 2013.

KOZINETS, Robert V. The field behind the screen: using netnography for marketing research in online communities. Journal of Marketing Research, 39, feb., 2002, p. 61-72.

KRAMER, Martin. Arab nationalism: mistaken identity. In: Daedalus 122, n. 3, 1993, p. 171-206. 
LE GOFF, Jacques. História e memória. Campinas: EdUnicamp, 2003.

LESSER, Jeff. A negociação da identidade nacional: imigrantes, minorias e a luta pela etnicidade no Brasil. São Paulo: EdUNESP, 2001.

LEVI-STRAUSS, Claude. O cru e o cozido. São Paulo: Cosac \& Naify, 2004.

. Natureza e cultura. in: Revista Antropos, vol. 3, ano 2, dez. 2009.

LIMA, Claudia Maria de Assis Rocha. Para Uma Antropologia da Alimentação Brasileira. In: Anais Seminário Gastronomia em Gilberto Freire. Recife: Fundação Gilberto Freire, 2005.

LINHARES, Maria Yeda. O Oriente Médio e o mundo árabe. São Paulo: Brasiliense, 2004.

LOPES, Margarida Santos. Novo dicionário do Islão. Casa das Letras, 2010.

LUCENA, Célia Toledo. Artes de lembrar e de inventar (re) lembranças de migrantes. São Paulo: Arte \& Cine, 1999.

MAALOUF, Amin. As cruzadas vistas pelos árabes. São Paulo: Brasiliense, 2004.

MAESTRI, Mario. Mouriscos em Portugal triste história, triste historiografia. In: Contra relatos desde el sur: apuntes sobre Africa y Medio Oriente, año II, n. 3. CEA-UNC, CLACSO, Córdoba, Argentina, dic., $2006 . \quad$ Disponível em: http://bibliotecavirtual.clacso.org.ar/ar/libros/argentina/cea/contra/3/maestri.pdf. www.clacso.org

MARTINS, José de Souza. Sociologia da fotografia e da imagem. São Paulo: Contexto, 2011.

MEIHY, José Carlos Sebe Bom. Manual de História Oral. São Paulo: Loyola, 1996.

MIGUEL, Salim. Nur na escuridão. Rio de Janeiro: TopBooks, 2004.

MINISTÉRIO DAS RELAÇÕES EXTERIORES (MRE). AMRIK: presença árabe na América do Sul. Brasília, 2005. 
MINTZ, Sidney W. Comida e antropologia: uma breve revisão. In: Revista Brasileira de Ciências Sociais, vol. 16, n. 47, out. 2001.

MISZTAL, Barbara A. Durkheim on Collective Memory. Journal of Classical Delhi, 2003.

MOKTEFI, Mokhtar; AGEORGES, Véronique. Os árabes na época de seu esplendor. São Paulo: Augustus, 1997.

MONTANARI, Massimo. Comida como cultura. São Paulo: Senac, 2013.

MONTENEGRO, Silvia. Comunidades Árabes en Brasil. In: AKMIR, Abdeluahed (Coord.). Los Árabes en América Latina. Biblioteca Casa Árabe. Madrid: Siglo XXI, 2009.

MOSCOVICI, Serge. Representações sociais: investigações em psicologia social. Rio de Janeiro: Vozes, 2003.

NORA, Pierre. Entre mémoire et histoire: la problématique des lieux. In: Les lieux de mémoire. Paris: Gallimard, 1984.

NUNES, Heliane Prudente. A imigração árabe em Goiás. Goiâna: EdUFG, 2000.

OLIVEIRA, Roberto Cardoso. Identidade étnica, identificação e manipulação. In: Sociedade e Cultura: Revista de Pesquisas e Debates UFG, v. 6, n. 2, 2003.

OLIVEIRA, Márcio S. B. S. Representações sociais e sociedades: a contribuição de Serge Moscovici. Rev. bras. Ci. Soc. 2004, vol.19, n.55, p. 180-186 . Disponível em: http://www.scielo.br/scielo.php?script=sci_arttext\&pid=S010269092004000200014\&lng=en\&nrm=iso.

http://dx.doi.org/10.1590/S0102-69092004000200014

OSMAN Samira Adel. Mascates árabes em São Paulo: concentração urbana e inserção econômica. In: Revista Cordis: Revista Eletrônica de História Social da Cidade, n. 2, 2009. 
PATARRA, Neide Lopes. Migrações internacionais: teorias, políticas e movimentos sociais. Disponível em: http://www.scielo.br/scielo.php?script=sci_arttext\&pid=S0103$40142006000200002 \& \operatorname{lng}=$ pt\&nrm=iso.

PINTO, Paulo Gabriel Hilu da Rocha. Ritual, Etnicidade e Identidade Religiosa nas Comunidades Muçulmanas no Brasil. In: Revista USP, n. 67, 2005, p. 228-250.

PINTO, Paulo Gabriel Hilu da Rocha. De la inmigración a la diáspora: los árabes en Brasil. In: Contribuciones arabes a las identidades iberoamericanas. Madrid: Casa Árabe, 2009.

PINTO, Paulo Gabriel Hilu da Rocha; MONTENEGRO, Silvia. As Comunidades Muçulmanas na Tríplice Fronteira: Identidades Religiosas, Contextos Locais e Fluxos Transnacionais. In: Anais da 26 Reunião Brasileira de Antropologia. Porto Seguro, 2011.

POLLAK, Michael. Memória, esquecimento, silêncio. In: Estudos históricos. Rio de Janeiro: CPDOC/FGV, v. 2, n. 3, 1989, p. 4.

PRADO, Coraci Helena. Reflexões sobre palavra, sentido e memória em Freud e Saussure. in: Ciências \& Cognição, vol 14 (1), 2009, p. 195-207.

QUEIROZ, Danielle Teixeira et al. Observação participante na pesquisa qualitativa: conceitos e aplicações na área da saúde. In: Rev. Enferm. UERJ, v. 15, n. 2, Rio de Janeiro, 2007, p. 276-283.

REINHARDT, Juliana Cristina. Dize-me o que comes e te direi quem és: alemães, comida e identidade. Tese de Doutorado. Programa de Pós- Graduação do Departamento de História, Setor de Ciências Humanas, Letras e Artes da Universidade Federal do Paraná. Curitiba, 2007.

RIBEIRO, Lidice Meyer Pinto. Negros islâmicos no Brasil escravocrata. Cad. CERU, v. 22, n.1, São Paulo, jun. 2011. Disponível em: http://www.revistas.usp.br/revusp/article/view/34861. Acesso em: 18 jul. 2012.

SAFADY, Jorge. A Imigração árabe no Brasil. São Paulo: Garatuja, 1994, Antologia árabe do Brasil. São Paulo: Safady, sd. 
SAFADY, Jamil. O café e o mascate. São Paulo: Safady, sd.

Panorama da Imigração Árabe. São Paulo: Safady, sd.

SAID, Edward W. Orientalismo: O Oriente como invenção do Ocidente. São Paulo: Companhia das Letras, 1996.

SALINAS, Samuel Sérgio. Islã: Esse desconhecido. Séculos VII-XIII. São Paulo: Anita Garibaldi, 2009.

SANTA CRUZ, Lucia. Desfazendo a mala: memórias de imigrantes na mídia. In: Contracampo (UFF), v.17, 2007, p.179 - 192.

SANTOS, Myrian Sepúlveda. Memória coletiva, trauma e cultura: um debate. In: Revista USP, n. 98, São Paulo, jun.-jul.-ago., 2013, p. 51-68.

SAYAD, Abdelmalek. A imigração: ou os paradoxos da alteridade. São Paulo: EdUSP, 1998.

SCHUTZ, Alfred. Sobre Fenomenologia e Relações Sociais. Rio de Janeiro: Vozes, 2012.

SEYFERTH, Giralda; PÓVOA, Helion; ZANINI, Maria Catarina; SANTOS, Miriam. Mundos em movimento: ensaios sobre migrações. Santa Maria: EdUFSM, 2007.

SILVA, Marilda Checcucci Gonçalves da Silva. O impacto da imigração europeia sobre a produção de alimento e a culinária do Médio Vale do Itajaí - SC. In: Antropologia e Patrimônio Cultural: diálogos e desafios contemporâneos. Manuel Ferreira Lima Filho, Jane Felipe Beltrão e Cornelia Eckert (Org.). Blumenau: Nova Letra, 2007.

SIMMEL, Georg. Sociologia da Refeição. Estudos Históricos, n. 33, Rio de Janeiro, jan.jun. 2004, p. 159-166.

Revista Brasileira de Sociologia da Emoção, vol. 4, n. 12, dez. 2005.

SIMMEL, Georg; MORAES FILHO, Evaristo. Georg Simmel: Sociologia. São Paulo: Ática, 1983. 
SMOLKA, Ana Luiza Bustamante. A memória em questão: uma perspectiva históricocultural. In: Educ. Soc., v. 21, n. 71, Campinas, jul. 2000. Disponível em: http://www.scielo.br/scielo.php?script=sci_arttext\&pid=S0101-

73302000000200008\&lng=en\&nrm=iso. Acesso em: 6 set. 2014. http://dx.doi.org/10.1590/S0101-73302000000200008.

SOLER, Luís. Origens árabes no folclore do sertão brasileiro. Florianópolis: EdUFSC, 1995.

SONATI, J. G.; VILARTA, Roberto; SILVA, Cleiliane de Cassia; Influências Culinárias e Diversidade Cultural da Identidade Brasileira: Imigração, Regionalização e suas Comidas. In: MENDES, Roberto Teixeira; VILARTA, Roberto; GUTIERREZ, Gustavo Luis (Orgs.). Qualidade de Vida e Cultura Alimentar, vol. 1, 2009, p.137-147.

SOUZA, Daniel Meirinho. A fotografia enquanto representação do real: a identidade visual criada pelas imagens dos povos do Oriente Médio publicadas na National Geographic. In: Observatorio Journal, vol.4, n. 4, 2010, p.117-137.

TAHAN, Malba. $O$ homem que calculava. Disponível em: ftp://ftp.unilins.edu.br/formigoni/utilitarios/O_Homem_que_Calculava.pdf.

Novas Lendas Orientais. Rio de Janeiro: Record, 2002.

TELLES, André. A Revolução das Mídias Estratégias de Marketing Digital para o Sucesso em Mídias Sociais. São Paulo: M. Books, 2010.

TRUZZI, Oswaldo Mário Serra. Patrícios: Sírios e Libaneses em São Paulo. São Paulo: HUCITEC, 1997.

Sírios e Libaneses e seus descendentes na sociedade paulista. In: FAUSTO, Boris (Org.) Fazer a América. São Paulo: EdUSP, 2000.

WITTE, James C. A Ciência Social digitalizada: avanços, oportunidades e desafios. In: Sociologias, ano 14, n. 31, Porto Alegre, set./dez., 2012, p. 52-92.

VALENTE, Maria Odette Cortes. Cozinha de Portugal: Madeira e Açores. Lisboa: Círculo de Leitores, 1995, p. 141. 
VARGENS, João Batista M.; MONTE, Carlos. A Velha Guarda da Portela. Editora Manati, 2001.

VARGENS, João Baptista de Medeiros. D. Pedro II, o primeiro arabista do Brasil? Catálogo comentado dos livros sobre a cultura árabe que pertenceram ao Imperador, encontrados no acervo da Biblioteca Nacional. Editora Almádena, 2013.

VICENZI, Roberta Aragoni Nogueira. Nacionalismo Árabe: apogeu e declínio. Tese de Doutorado. Universidade de São Paulo, 2006.

VILELA, Elaine Meire. Sírios e Libaneses: Redes sociais, coesão e posição de status. In: Revista Brasileira de Ciências Sociais, vol. 26, n. 76, jun., 2011.

VILELA, Ivan. A Viola. Ensaio elaborado especialmente para o projeto Músicos do Brasil: uma Enciclopédia. 2008-2009. Acesso em: jan. 2014. Disponível em: http://www.ivanvilela.com.br/pesquisador/ivanvilela-aviola.pdf.

VILLAR, Valter Luciano Gonçalves. A presença árabe na literatura brasileira: Jorge Amado e Milton Hatoum. Dissertação de Mestrado. Universidade Federal da Paraíba, 2008.

YASBEK, Mahassen Hanna; ABRAHÃO, Salma Daud. Receitas árabes tradicionais do norte do Líbano. São Paulo, Editora Revan, 2001.

WOORTMANN, Ellen Fensterseifer. Temas em cultura e alimentação. In: Horiz. Antropol., vol.15, n.32, 2009, p. 355-359 . Disponível em: http://www.scielo.br/scielo.php?script=sci_arttext\&pid=S0104$71832009000200015 \& \operatorname{lng}=$ en\&nrm=iso. http://dx.doi.org/10.1590/S0104-71832009000200015.

WOORTMANN, Klass. A Comida, a Família e a Construção do Gênero Feminino. In: Revista de Ciências Sociais, 29 (1), 1986.

ZAIDAN, Assaad. Raízes Libanesas no Pará. Belém, 2001. 
Consultas eletrônicas:

CHACRA, Gustavo. 8 coisas que você não sabia sobre... o Líbano. Disponível em: http://www1.folha.uol.com.br/revista/rf0603200501.htm.

DIB, Márcia. A mulher árabe. Entrevista concedida à Revista Shimmie em 2012. Disponível em: http://marciadib.blogspot.com.br/2013/01/a-mulher-arabe.html

FARAH, Paulo. Entrevista publicada por Sul21. Disponível em: http://www.sul21.com.br/jornal/ha-campanha-de-desinformacao-contra-mundo-arabe-dizpaulo-farah/

FARHAT, José. Fundamentalismo que envergonha. Disponível em: http://www.icarabe.org/artigos/fundamentalismo-que-envergonha

FERNANDEZ, Belen. Como escrever sobre muçulmanos. Disponível em: http://www.icarabe.org/artigos/como-escrever-sobre-muculmanos

HAJJAR, Claude. Entrevista concedida ao Portal Vermelho pela autora. Disponível em: http://www.vermelho.org.br/coluna.php?id_coluna_texto=2653\&id_coluna=25. Acesso em: 21 abr. 2014.

HOUAISS, Antônio. As projeções da língua árabe na língua portuguesa. Conferência para o Centro de Estudos Árabes da USP, 1986. Disponível em: www.hottopos.com/collat7/houaiss.htm. Acesso em: jul. 2013.

KHATLAB, Roberto. Elias Farhat, o poeta líbano-brasileiro do arabismo. Disponível em: http://www.icarabe.org/artigos/elias-farhat-o-poeta-libano-brasileiro-do-arabismo

OSMAN Samira Adel. Registros da experiência na história. ICArabe, 2009. Disponível em: http://www.icarabe.org/artigos/registros-da-experiencia-na-historia. Acesso em: 13 jan. 2014. 
ANEXOS 


\begin{abstract}
ANEXO 1
Carta de apresentação do questionário enviado aos participantes da primeira etapa da pesquisa, de cunho exploratório, intitulada "Projeto Presença Árabe no Brasil em Imagens".
\end{abstract}

Brasília, março de 2013

Prezado/a senhor/a,

Obrigada por aceitar participar desta pesquisa, que visa investigar as diferentes presenças árabes no Brasil por meio de hábitos e tradições culinárias. Este trabalho está sendo desenvolvido no âmbito do meu doutorado em sociologia pela Universidade de Brasília e pauta-se na compreensão de que a alimentação pode ser entendida como um fenômeno social, estando fortemente relacionado a temas como memória e identidade. Neste sentido, utilizando as tradições alimentares como unidade de análise, acredito ser possível identificar uma presença árabe no Brasil bastante plural, a qual se manifesta por meio de diferentes sentidos de pertencimento, identidades e relações sociais.

Sua contribuição nesta etapa da pesquisa é de extrema importância. Gostaria de lembrar que os dados informados neste questionário são absolutamente confidenciais e que estão em consonância com os aspectos éticos da pesquisa acadêmica, desde a entrada em campo, passando pela consolidação dos dados, elaboração do relatório final e divulgação dos resultados.

Após responder este questionário, por favor, o envie em anexo, ou no corpo do texto, para o seguinte endereço eletrônico: presencaarabe@gmail.com.

Aproveito para colocar-me à disposição para qualquer esclarecimento que se faça necessário.

Atenciosamente,

Patrícia El-moor

Pesquisadora - Doutoranda em Sociologia pela Universidade de Brasília 


\begin{abstract}
ANEXO 2
Roteiro de entrevista mediada, realizada com participantes da primeira etapa da pesquisa, de cunho exploratório, intitulada "Projeto Presença Árabe no Brasil em Imagens".
\end{abstract}

Levantamento de dados primários para a pesquisa: Alimentação, memória e identidade: hábitos e tradições culinárias árabes no Brasil

1. Identificação:

- Nome:

- Idade:

- Escolaridade:

- Cidade de nascimento - Estado - País

- Cidade de residência - Estado - País

2. Identificando "presenças árabes" no cotidiano por meio de hábitos e tradições alimentares

- Você possui ascendência árabe?

- Se sim, seu/s familiar/es procede/m de qual ou quais país/es?

- Caso possua ascendência árabe, você sente que vive em um ambiente que procura preservar a identidade de seu país de origem ou de sua família?

- Caso sim, por favor, comente de que forma você percebe essa experiência. Caso não sinta que vive em um ambiente influenciado pela presença árabe, por favor, siga para a questão seguinte.

- Quando falamos sobre comida e hábitos alimentares tipicamente árabes, em qual (ou quais) país/es você pensa? 
- Quando falamos sobre comida e hábitos alimentares tipicamente "árabes", de qual ou quais pratos (ou alimentos) você se recorda?

- Você acredita ser possível identificar uma influência "árabe" nas tradições culinárias brasileiras?

- Caso sim, poderia citar algum exemplo desse fenômeno cultural? Caso não acredite ser possível identificar qualquer tipo de influência "árabe" nas tradições culinárias brasileiras, por favor, siga para a questão seguinte.

- Na cidade em que você vive, você percebe algum tipo de presença árabe? Caso sim, por favor, comente sobre a essa impressão (como você observa isso e como isso pode intervir no seu cotidiano).

- De qual ou quais forma(s) você acredita ser possível observarmos diferentes presenças árabes na cultura brasileira?

- Você possui alguma crença religiosa? Caso sim, qual?

- Para aprimoramento deste levantamento exploratório sobre como as presenças árabes no Brasil podem ser identificadas por meio de hábitos e tradições culinárias, você gostaria de acrescentar alguma observação?

- Você poderia indicar uma pessoa para também participar dessa pesquisa? Caso sim, por favor, informe nome, telefone e/ou endereço eletrônico.

Obrigada por sua participação na pesquisa!

Patrícia El-moor

Pesquisadora - Doutoranda em Sociologia pela Universidade de Brasília

presencaarabe@gmail.com 


\section{ANEXO 3 \\ Script básico para realização das entrevistas face a face, semiestruturadas, realizadas em Brasília com árabes e descendentes.}

- Obrigada por aceitar participar da pesquisa. Gostaria de começar perguntando seu país de origem ou, caso você seja brasileiro/a, o país de origem da sua família.

- Conte como foi sua chegada ou a chegada de sua família ao Brasil

- Caso possua ascendência árabe, você sente que vive em um ambiente que procura preservar a identidade de seu país de origem ou de sua família? Caso sim, por favor, comente de que forma você percebe essa experiência.

- Quando falamos sobre comida e hábitos alimentares tipicamente árabes, em qual (ou quais) país/es você pensa?

- Quando falamos sobre comida e hábitos alimentares tipicamente "árabes", de qual ou quais pratos (ou alimentos) você se recorda?

- Você acredita ser possível identificar uma influência "árabe" nas tradições culinárias brasileiras? Caso sim, poderia citar algum exemplo desse fenômeno cultural?

Na cidade em que você vive, você percebe algum tipo de presença árabe? Caso sim, por favor, comente sobre a essa impressão.

- De qual ou quais forma(s) você acredita ser possível observarmos diferentes presenças árabes na cultura brasileira?

- Para aprimoramento deste levantamento exploratório sobre como as presenças árabes no Brasil podem ser identificadas por meio de hábitos e tradições culinárias, você gostaria de acrescentar alguma observação? 


\section{ANEXO 4}

\section{Divulgação do Projeto Presença Árabe no Brasil em Imagens}

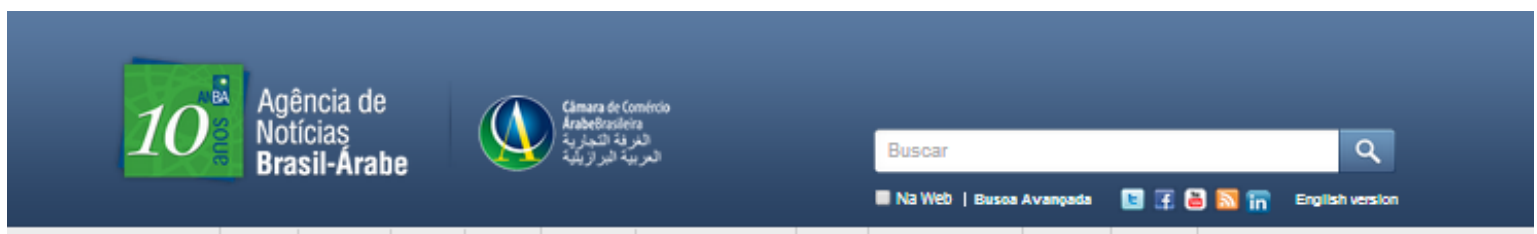

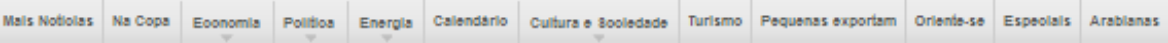

Incilo * Noticlas * Orlentie-se

01/11/2011 - 16:54hs

Compartilhe: $\mathbf{f} \square \mathrm{M}+$

\section{Memória árabe em imagens}

Tese de doutorado de socióloga de Brasilia visa resgatar o imaginário do povo brasileiro sobre os arabes por meio de fotos. Projeto reunirá imagens enviadas de todo o Pais.

Aurea Santos
aurea.santos@anba.com.br

Săo Paulo - A tese de doutorado da socióloga Patrícia El-moor, da Universidade de Brasília, quer identificar o que o povo brasileiro pensa sobre os árabes. No entanto, diferente das dezenas de pesquisas já feitas sobre história dos árabes no Brasil, Patricia escolheu um jeito diverso de fazer o seu trabalho. Ela quer reunir fotos, tiradas por pessoas do Brasil inteiro, que mostrem lugares, pessoas, objetos ou o que quer que seja que elas. identifiquem como parte da presença árabe dentro do território nacional.

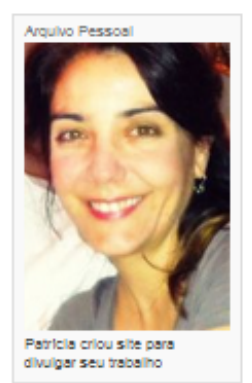

'A ideia é mostrar como a sociedade criou o imaginário da presenca árabe no Brasil, afirma Patricia, que é bisneta de ilbanneses. Quero descobrir o que está no pensamento do brasileiro quando se fala em arabes. Segundo a pesquisadora,

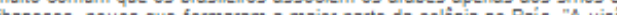

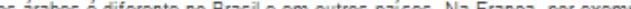
quando se fala em árabes, eles pensam nos argelinos, nos marroquinos", ont

O projeto inicial de Patrícia para sua tese era o de estudar os personagens árabes nas novelas nacionais. Iria mostrar um pouco dos estereotipos [nestes personagens]. Porem, se tratasse das novelas, ira mostrar apenas a visáo dos autores. Pela fotografia eu terei mais material para poder analisar. Alemr disso. poderej contar com a participacáo de pessoas do Brasit todo, que eu nho tare

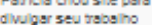

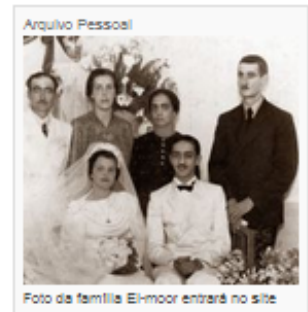

Para divulgar seu trabalho e receber as fotos. Patrícia criou o site "Presenca Arabe no. Brasil", que comecou a ser divulgado na segunda-feira (01) e, em seu primeiro dia, recebeu 12 imagens. As fotos ainda nắ podem ser vistas pelos visitantes, mas. Patricia quer organiza-las para mostrar todas quais partes do Brasil elas vieram.

"A partir do ano que vem, vou montar o site em forma de mapa, para mostrar de onde as fotos estắo vindo. Já estou montando um banco de imagens", diz. "Das fotos que recebi, a maioria sáo de detalhes de pessoas, que mostram duas mulheres muculmanas". 'Vou tentar atualizar a cada semana. Até sexta, as primeiras fotos iá estarăo no ar", diz.

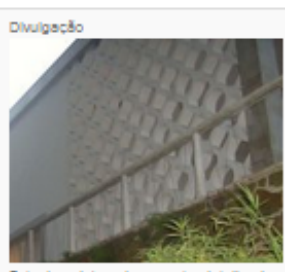

Para contribuir com o projeto, é preciso que a pessoa seja a autora das colaborador pode optar por ter ou năo seu nome divulgado no site. A socióloga diz que náo criou muitas expectativas sobre que tipos de imagens ira receber. "Nào quero influenciar com as minhas palavras, quero que as pessoas enviem o que vier a suas cabeças", afirma.

Para mais informapoóes sobre como colaborar com o projeto "Presença Arabe no Brasil', basta acessar o link

http://Www. presencasarabe.com/ \#loontact. As fotos devem ser enviadas

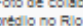

Otmian por t-mat
I Dowilosd em Pof Comentar
Inotícias | 1 a 10

$10103 / 2014$ - 16-34ns O segredo de um IIbanAs em IIvro

26/11/2013- 16:00ns Embarque para o iraques

06/11/2013 - 07:00ns Maravilihas do Oriante em Berlim

0309:2013 - 18.00ns Gamal Ghitany para os brabliairos

2208:2013 - 20000n Para entender o Haj]

2207/2013 - 1455ns Festival de dancas troca atraç0es 10006/2013 - 20,000 Exposiçato traz mamorias do Libano 27/05/2013 - 13:15ns Enredos de um filho do Libano $0905 / 2013-1308 \mathrm{~s}$ Literatura arabe para crianças 0404:2013 - 18.00075 Lamica, a cantora IIbanesa da wob

\begin{tabular}{|l|l|}
\hline Anterior & Proximas \\
\hline
\end{tabular}




\section{ANEXO 5}

\section{Glossário Cozinha Árabe ${ }^{81}$}

Arayess: Sanduíche com carne de cordeiro

Ataif (katayef, kataif, atayef): Sobremesa tradicional árabe preparada com pequenas panquecas cujo recheio pode ser de nozes, queijo, entre outros, além de uma calda doce feita preparada com água de rosas, flor de laranjeira ou mel.

Baba ghanoush: É uma espécie de purê feito com berinjela assada ou grelhada, tahine e suco de limão.

Baklava (baclava): É um tipo de pastel elaborado com uma pasta de nozes trituradas, envolvida em massa filo e banhada em xarope ou mel.

Barazeq: Biscoito de sementes de gergelim e mel.

Basbousa: Também conhecido como revani (turco), ravani e ranavi (grego), é um doce feito de sêmola em calda que se assemelha a um bolo denso.

Burghul (bulgur, burgol): No Brasil é conhecido como o trigo para quibe. Nas receitas árabes, pode ser usado "inteiro", por exemplo, para sopas; "grosso", como substituto do arroz; e "fino", para tabule, quibe etc.

Cardamomo: Trata-se da semente de uma planta originária da Índia, bastante utilizada como tempero e aroma de pratos diversos. O famoso café árabe é comumente aromatizado com cardamomo.

Cuscuz (couscous): é um prato árabe originário do Magrebe que consiste num preparado de sêmola de cereais, principalmente o trigo. Acompanha vegetais, carnes e, raramente, peixes. No Brasil, pode ser feito à base de farinha ou polvilho, de milho, arroz ou mandioca.

\footnotetext{
${ }^{81}$ Fontes: YAZBEK \& ABRAHÃO (2001) e http://correiogourmand.com.br/info_01_cultura_gastronomica_03_cozinhas_do_mundo_arabe_05_glossari o.htm
} 
Cúrcuma: Tempero de origem indiana de cor amarela-laranja, que além do sabor dá também cor, muito parecido com o açafrão.

Falafel (ou felefel): Bolinhos de grão de bico, fritos, com cebola, alho e coentro.

Fatayer: No Brasil virou sinônimo de esfirra, embora originalmente, a Fatayer seja maior e assada na chapa. Comumente recheada com espinafre, escarola, carne ou queijo.

Fattoush: Salada que leva pão em pequenos pedaços, pepino, tomate e hortelã.

Ful: Pasta de feijões negros e lentilhas vermelhas cozidos em fogo lento e temperado com suco de limão, óleo de oliva e cominho.

Halib: Leite

Halwa (halva): Doce feito com massa de sementes de gergelim torradas, moídas e misturadas com açúcar derretido. As receitas podem variar quanto aos ingredientes: mel, baunilha, pistache, frutas ou nozes.

Harira: Trata-se de um guisado ou uma sopa forte, muito popular em todo o Magrebe durante o Ramadan para quebrar o jejum, composta de carne de borrego cozida lentamente com grão-de-bico, ervas aromáticas e outros temperos

Harissa: É uma pasta de pimenta fresca, alho e azeite, de origem tunisiana, porém, difundido em todo o mundo árabe.

Hommus: Pasta feita com grão-de-bico e tahine, normalmente temperada com suco de limão, cominho, alho, azeite e páprica.

Jebne: Queijo branco

Kafta: Espetinho de carne moída grelhada, temperado com cebola e especiarias.

Kamun: No Brasil é conhecido como cominho, um tipo de especiaria aromática e digestiva. Suas sementes se assemelham às da erva-doce. O cominho é muito usado nos países árabes e quase sempre junto com a páprica doce.

Kadaif (kanafeh, knafeh, kataifi, konafa, konafah, kunafah, kunafi, kadayif): Massa fresca, com fios longos, finos, conhecida no Brasil como "cabelinho de anjo". É utilizada, principalmente, na confecção de doces, mas também em alguns pratos salgados. 
Qahwa: Café

Kebab: Espeto de carne grelhado.

Khubz Arabi: Conhecido no Brasil como "pão sírio", é um pão leve e macio, em formato redondo.

Kibbeh: É o que no Brasil é bastante conhecido como quibe, um bolinho de carne de cordeiro moída com trigo.

Kibbeh Naye: Quibe cru.

Kouzi: Cordeiro cozido no forno sobre uma camada de arroz, de modo com suco da carne seja absorvido pelo arroz.

Kuzbur: Coentro, erva fresca muito semelhante à salsinha, com um aroma mais forte. Usado com carnes e saladas.

Laban (ou Zabadi): Coalhada Fresca. A Coalhada Seca é chamada de "Laban Musafa" ou "Labne".

Labneh: Creme de queijo muito denso feito de iogurte.

Lahma bi Ajeen: Também conhecido como "pizza árabe".

Lokum (loukoum, loukoumi, Loukoum, turkish delight): Doce de origem turca, cujo nome original completo é "rahat lokum", que se difundiu por todo o mundo, sendo muito apreciado. Pode ter vários aromas e cores. O mais tradicional é rosado e aromatizado com água de rosas. Algumas receitas incluem frutos secos picados, como nozes, avelãs ou pistache.

Loubia: Feijões cozidos no molho de tomate.

Mazaher: Água de flor de laranjeira.

Mâ el Ward: Água de rosas.

Mahalabi: De origem libanesa é um manjar a base de leite, servido frio.

Mamoul (Maamoul): Doce árabe feito à base de semolina, leite e manteiga, com recheio de tâmaras, castanhas e água de flor de laranjeira, açúcar, margarina e outros ingredientes. 
Meghli: Espécie de pudim de arroz, de origem libanesa, tradicionalmente preparado em ocasiões especiais. É feito com leite fresco, água de rosas, mel e pistaches picados. Mehchi: Também conhecido no Brasil como "Charuto". É feito com vegetais recheados com carne picadinha ou moída. Em algumas recitas usa-se a carne misturada com arroz no recheio. O mais comum é usar berinjela, abobrinha, folhas de uva, de couve ou repolho.

Mezze: Entradas, aperitivos oferecidos em pequenos pratos que antecedem uma refeição árabe.

Mubassal: Fritada de cebola.

Mutabel: Berinjela com tahine, azeitonas e suco de limão.

Nabulsi: Queijo branco salgado, tradicional nos territórios palestinos, a Jordânia e países vizinhos. É produzido, principalmente, com leite de cabra e de ovelhas, embora o leite de vaca, também, seja usado.

Quiozi: Torta síria recheada com arroz, frango, amêndoas, uvas passas e pinoli.

S'fiha (esfirra): é uma pequena torta assada originária da Síria e encontrada em outros países do Oriente Médio: na Jordânia, no Líbano, na Palestina e no Iraque. Existem diversas receitas diferentes de esfirra; a forma tradicional sempre é feita com massa de pão, assada no forno com recheios que podem ser de carne de carneiro, carne bovina, queijo, coalhada ou verduras temperadas.

Shawarma: Prato originalmente composto de fatias finas de frango ou carne de vaca assados em um espeto vertical e servidas no pão sírio com legumes e outros acompanhamentos.

Sheesha (narguilé): Cachimbo pra fumar folhas de fumo o fruta seca, a fumaça passa antes por um filtro de água.

Shish Tauk: Espetinhos de frango na brasa.

Shurba: Sopa

Snoubar: Pinoli

Sukkar: Açúcar 
Tabbuleh: Conhecido no Brasil como Tabule, é uma salada de trigo, tomates, hortelã e salsinha.

Tahine: Uma pasta preparada a partir do processamento das sementes de gergelim tostadas.

Taklia: Tempero feito com alho e coentro.

Tamr: Tâmaras

Tarator: Maionese de pinoli, coentro e limão.

Zaitun: Azeitonas

Zattar: Misto de especiarias, de sabor picante e salgado, composto por gergelim, cominho, coentro, orégano, manjerona, sal refinado, colorau e acidulante ácido cítrico. 